84

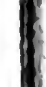

.

.

.

.

(1)

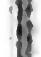




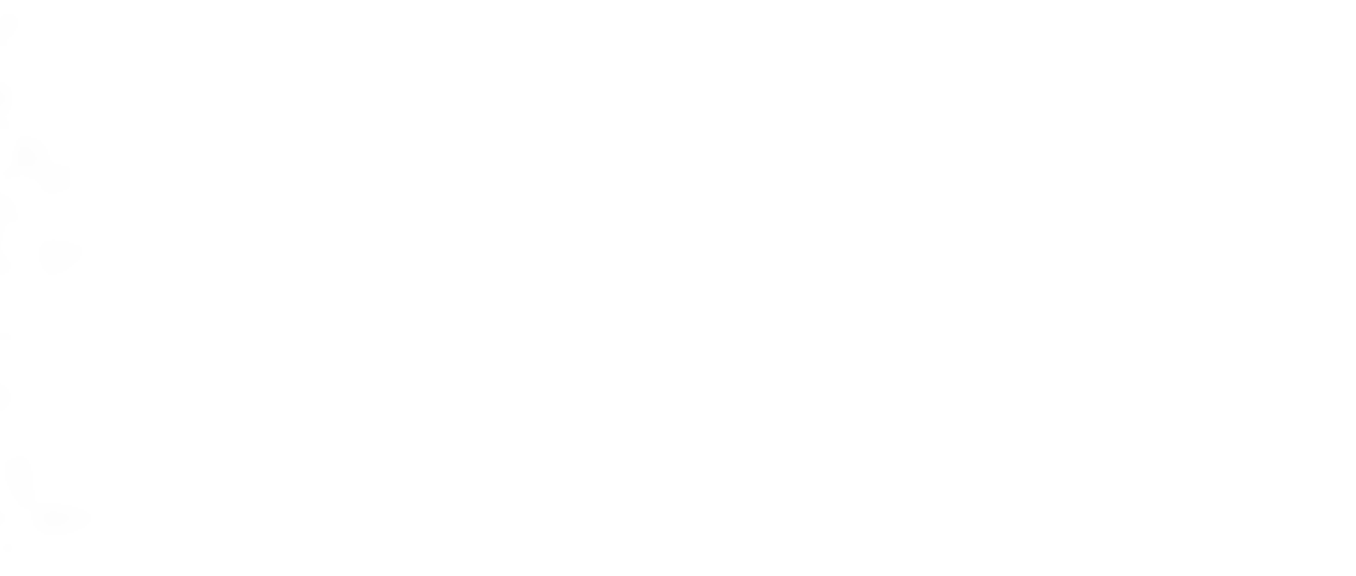
(1)
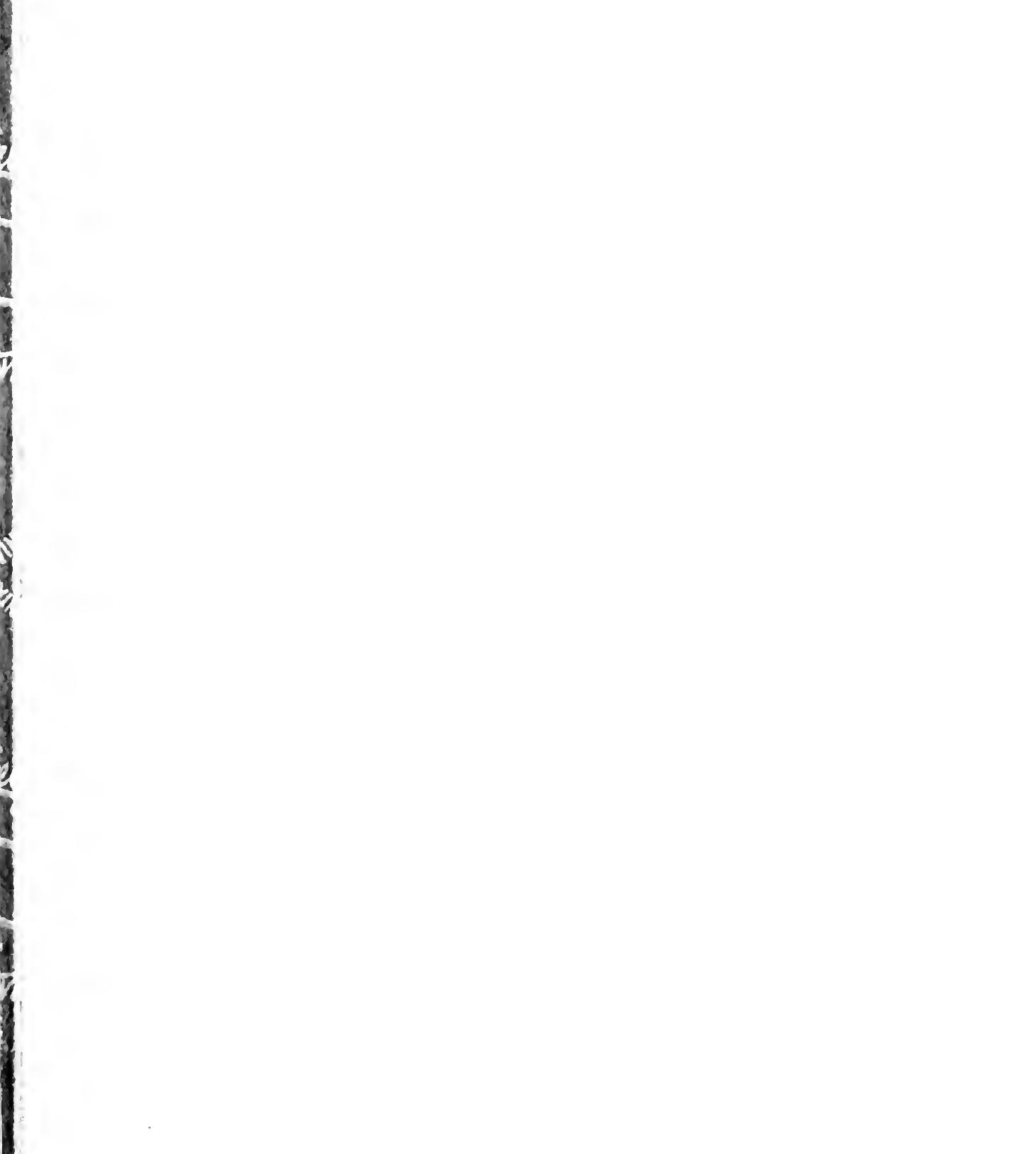



FRENCH PROPHETS OF YESTERDAY 



\title{
A STUDY OF RELIGIOUS THOUGHT UNDER THE SECOND EMPIRE
}

\author{
BY
}

AGRÉGE DE L'UNIVERSITE, ASSISTANT PROFESSOR OF FRENCH IN THE LELAND STANFORD JUNIOR UNIVERSITY, CALIFORNIA

NEW YORK 
First Published . I9I3

[All rights reserved.] 


\section{CARISSIMÆ CONJUGI}

Ex animo factus meo, tibi sit hic liber.

A. L. G. 



\section{CON'TEN'TS}

Introduction-Scope AND Method of this Book

PAGE

\section{BOOK I}

CHAPTER

I. Catholicism . . . . . . . 25

II. Protestantism . . . . . $\quad$. 70

\section{BOOK II}

I. Voltamianishi . $\quad . \quad$. $\quad$. 101

II. Romantic Humanitarianish . . . . . 118

\section{BOOK III}

I. The New Spirit-Background and Influences . 159

II. The Poets of Scifnce and Despair. . $\quad 180$

III. Critics and Historians: Sainte-Beuve, Taine . 201

IV. ERnest Renan . . . . . . . . 224

Conclusion . . . . . . . . 256

Biblographical Note. . . . . . . . 282

INDEX . . . . . . . . . . 



\section{ANALY'TICAL 'TABLE OF CON'TENTS}

\section{INTRODUCTION: SCOPE AND METHOD OF THIS BOOK}

1. Is France rost to Christianity? Anti-cloricalism-Anti-catholicism-Anti-christianity and ${ }^{\circ}$ Irreligion-A spiritual, not a moral issue.

2. Importance of the Question . . . . . . . . France still one of the world's great powers-Her spiritual influence-Wider significance of tho problem.

3. Higtorical Treatment Necessary .

Why the period of the Sccond Empire was selected.

4. Division: Theologr, Metapirsics, Positivism -
Comte's Law of the Three States - Theology-MetaphysicsPositivisin.

\section{BOOK I}

\section{CHAPTER I-CATHOLICISM}

1. Character and Evolution of Catholicism from 1848 to 1870 . Is there an unknown Catholic literature?-Number and influence of the Catholics-The Church identified with reaction: $(a)$ Roman Affairs; (b) Anti-socialistic reaction - Growth of Ultramontanism - War on modern civilisation.

2. Estheticism in Religion: The Satanic School
Romanticism in Religion : from Orthodoxy to Diabolisin-Ingredients of Diabolism : $(a)$ sin ; $(b)$ mystery ; $(c)$ sensuality ; $(d)$ pathology-Baudelaire : Degree of sincerity-Aảhesion to Catholicism - Enjoyment of systematic depravity - Flashes of aspiration and remorse-Barbey d'Aurevilly: Apostle of Dandyism-Devil-worshipper-Realistic novelist-Influence of the Diabolists.

3. The Gospel of Authonity: Barbey d'Aurevilly and Veuillot Influence of Joseph de Maistre-Louis Veuillot: atmosphere of violence-Intolerance-Fondness for paradox-A man of the people-A journalist-A moralist: The Odours of Paris-Kind and loving at heart-Comparison with Proudhon.

4. The Ltberal Cathorics - 4 -The Liberal Catbolic group under Liberal Catholicism bofore 1843 - The Liberal Catholic group under
the Second Republic-Under the Empire-Political insignificance - Social prominence-Difficulty of their religious position : Montalembert and the Congress of Malines-Mgr. Dupanloup and the Syllabus-The Council of the Vatican.

5. Pirlosophers: Mar. Maret and Father Gratri

Mgr. Maret: a conservative reformer-The evolution of dogmaConstitutional reform his goal-Father Gratry: wide interestsInductive rationalism-Eclectic philosophy-Warm-heartedness.

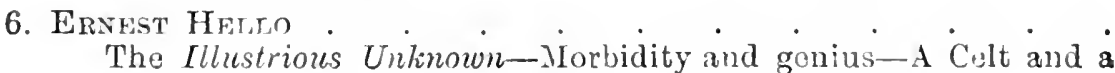
The Illustrious Unknown-Norbidity and gonius-A
mystic-Unevenness-Romanticism-Small influnce.

7. Coxclustor.

No alternative but theocracy and frce-thought.

\section{CHAPTER II-PROTESTANTISM}

1. The Struggle between Ortiodoxy and Liberalisi

The French Protestants are not foreign, but different-The 


\section{ANALYTICAL TABLE OF CONTENTS}

conflict of principles within Protestantism: the case for Liberalism ; for Orthodoxy-The conflict in France from 1848 to 1872The Revival and the Free Evangelical Churches-The Revue de Strasbourg-Athanase Coquerel, junior, and Guizot-The Declaration of Faith of 1872 .

2. Guizot .

Many-sidedness-Activity in retirement-Early influences and return to faith-The Meditations-Philosophical foundations of belief-Historical foundations-The champion of conservation and authority.

3. Scherer

Early influences-The Oratoire : period of strict orthodoxy-The Revue de Strasbourg: liberalism-Ends in universal relativismSadness-Stoic resignation-Peace.

4. QUINET

Thoughts of transitional reform-Quinet before 1848-After 1852: return to the religion of conscience-The religious policy of the French Revolution: advocacy of persecution-Interest in Unitarianism-Remains a free-thinker-Creation-No clear message, but an example.

5. CoNClusion

Requiescat in pace.

\section{BOOK II}

\section{CHAPTER I-VOLTAIRIANISM}

1. Decline and Revival of Voltairianism

Two kinds of Voltairianism: positive and negative-Scoffing scepticism the result of hypertrophied common sense-Decline of Voltairianism about the middle of the nineteenth centurySurvivors and fossils: Béranger, Viennet, Doudan, CousinRevival of Voltairianism as a result of the Catholic reactionRomances and histories-The stage-The political world : Prince Napoleon and Sainte-Beuve in the Senate-The Good Friday orgy.

2. Spiritual Nihilism: Mérimée . . . . . . . . Education-Difficult position in politics-At Court and in Society - Mérimée as an earnest doubter-His Protestant funeralSmiling despair-Barrenness of Voltairianism.

\section{CHAPTER II-ROMANTIC HUMANITARIANISM}

1. Formation of Romantic Humanitarianism (Before 1848) . Romanticism, exhausted as a literary movement, assumes a political and social form-What is Romanticism?-Conflicting definitions-Hypertrophy of the Ego-Apparent contradiction between the ideals of Romanticism in 1820 and in 1848-From reaction and individualism to democracy and Humanitarianism - Eelief in the poet's mission-Disappointment with the Restoration-Three avenues of change: the national sentiment; the rise of the social problem; the free Christianity of LamennaisThe Romantic faith: France as a Messianic nation-Mankind as the incarnation of the Divine-Nature-worship and Pantheism a minor element-Sincerity and potency of that faith.

2. Micheliet • • • • • • • • • •

Triumph of Romantic Humanitarianism in February, 1848, and downfall in June-The Romantic leaders in defeat, poverty, and exile: Lamennais, Lamartine, George Sand, Quinet, Leroux, Reynaud, Enfantin, Barrault, Pelletan, Michelet and QuinetMichelct: all life and love-Sincerity-Energy-Justice-The foundation: the Hearth (home), the city, the fatherland-The 


\section{ANALYTICAL TABLE OF CONTENTS}

sister nations-The Revolution-Nature-God-The Church: hostility to Catholicism-La Bible de l'Humanite-Nichelet's influence.

3. Victor Hugo

Primacy-Difficulties: political prejudices not yet silencedHeterogeneous complexity of his thought-To what extent he was a time-server-The High Priest of Romantic DemocracyFaithful to spiritualistic Theism-A second aspect: the "weird Titan "-The Dreamer-Manicheism-Conflicting conceptions of human destiny : fatalistic optimism, fatalistic pessimism-Pantheistic naturalism-Conscience, liberty, and responsibilityConflicting sanctions: conscience-Optional immortality-Astral transmigration-Universal metempsychosis-Tho poem GodSpiritual greatness of Victor Hugo: conscience, love, and the shudder of the infinite.

\section{BOOK III}

CHAPTER I-THE NEW SPIRIT: BACKGROUND AND INFLUENCES

1. Characteristics .

Triumph of the scientific spirit-Attending gloom-Relativity and evolution-The experimental method-How science affected literature and religion. 2. Saint-Simon, Comte, Littré -
Saint-Simon : a "New Christianity," mankind the object, industry the method of service-Auguste Comte: the Law of the Three States-The classification of sciences-The religion of Humanity-Littré : scientific atheism.

3. P.-J. ProudhoN .

Transition from Romantic to Scientific Socialism-Antitheism: its elements-The God he attacks is the Absolute-De la Justice dans la Rérolution et dans l'Eglise-Three fundamental ideas: relativism, justice, humanity.

\section{CHAPTER II-THE POETS OF SCIENCE AND DESPAIR}

Science And Poetry
Alfred de Vigny: his consistency-His life no clue to his thought -Attitude towards organised Christianity - The religion of thought-Fessimism: the curse of genius-Nature indifferent - God responsible: antitheism-The Ethics of Despair: stoic pride, honour, pity, service-The Dawn: Thought conquers Pessimism-The "school" of Vigny?-Leconte de Lisle, Mime. Ackermann, Sully-Prudhomme, Jean Lahor.

2. LeConte DE LisLe

The faultess eraftsman-Art for Art's sake-Impassibility-A few personal notes-Radical pessimism-Antitheism-Qain: the rebellion of Justice - Misanthropy - Spiritual nihilism - Onesidedness.

\section{CIIAPTER III-CRITICS AND HISTORIANS:} SAINTE-BEUVE, TAINE

1. Sainte-Beuve .
Politico-religious attitude: $a$ supporter of the Empire-Respectful of the Church until 1859-Growing hostility, 1859-65 -Open leadership of anti-clerical Free-thought after 1865-Inner evolution: Port Royal-Montaigne and Pascal-Scepticism and faith-Dissatisfied with Supernaturalism and Naturalism-Make- 


\section{ANAL YTICAL TABLE OF CONTENTS}

shifts: lareligion des honnêtes gens-Scepticism-Curiosity-Love of truth-Final term: scientific stoicism-Amiel's tribute.

- TAine.

A nastel-Attacks Eclecticism, and Romantic sentimentalism in philosophy-Science for Science's sake-Monistic determinism -Influence of the eighteenth century: classical rationalism of Taine-The Eternal Axiom his God--Esthetic and social appreciation for historical religions, but no faith-Patches of pantheism in his writings-A sensitive and passionate soul-Pessimism, the second Mal du Siècle-Stoicism-Lack of tenderness-Dangers of his influence.

\section{CHAPTER TV-ERNEST RENAN}

1. Influences, 1923-49.

Brittany - Catholicism - The priests-Saint-Nicolas and Abbé Dupanloup_Saint-Sulpice - Issy - Rationalism-Philology and Germany-Crisis-Berthelot.

2. Renan's Life and Works from 1848 to 1870

1848-The Future of Science-Mission to Italy-The Coup d'Etat - Mission to Phœnicia-Professor in the Collège de France-Vie de Jésus-Success - Contemporary opinions: Free-thinkers, Catholics-Four conceptions of a Life of Jesus-Renan's a historical romance-Lack of inner unity-The Sciences of Nature and the Historical Sciences-The Apostles-Saint Paul-Questions of the Times-Political velleities-Declaration of war.

3. Renan's Religious Philosophy, 1848-70

A servant of the ideal-Later "Renanism"-Influence of the events of 1870-71-Sceptical only as to symbols-Causes of his excessive indulgence-Two standards: scientific Stoicism for Prospero, Epicurianism for Caliban-Renan's Positivism-Exclusion of piecemeal supernaturalism-His attitude on the question of recorded miracles-Based on Rationalistic prejudices, not on scientific principles-Esthetic and spiritual value of religious symbols-Mretaphysics: nothing is, everything grows-God: in the making, the growing consciousness of the world-Conclusion : a power for good.

\section{CONCLUSION} A Retrospect AND A ForfCAS'
Spiritual activity of the period studied-Its cheerlesinessAnxious questionings as to the religious future of France.

1. A Return to Christianity: Protestantism and Catholicism . Protestantism in France represents neither the past nor the future-Catholicism: its alliance with reaction-Can it be severed?-No chance for a compromise-Possibility of a schisin -Great material and spiritual assets of the Church-Voltairianism on the wane, but national return to Catholicism improbable.

2. New Churches and New Religions . . . . .

The Revolutionary Cults-The Churches of the Romantic period (Abbé Châtel, Mapah, etc.)-Modern minor religions-SaintSimonism-Comte's Positivist Church-Natural Religion (Eclecticism or Theism)-Substitutes for religion: Patriotism-The Revolution --Socialistic Humanitarianism-Science.

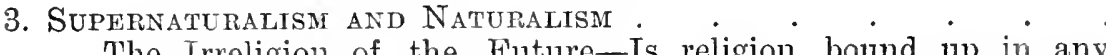
The Irreligion of the Future-Is religion bound up in any theology?-Optimism of the Naturalist_-Pessimism of the Supernaturalist-Doubts and fears-Hope unconquerable. 


\section{INTRODUCTION}

\section{SCOPE AND METHOD OF THIS BOOK}

\section{Is France lost to Christianity?}

Is France, the land of the Crusaders, the eldest daughter of the Church, irrevocably lost to Christianity? Such is the problem upon which this book would attempt to throw some light.

That Anti-clericalism, or opposition to the political influence of the Church, is one of the cardinal principles of the Third Republic, cannot be doubted for a moment. Active resistance to "the encroachments of Rome" was the policy, not of narrow fanatics and hot-headed Radicals alone, not merely of brilliant and somewhat erratic individuals like M. Clémenceau, but of men like Gambetta, Jules Ferry, Waldeck-Roussean, in every respect the strongest and sanest statesmen of the regime. Anticlericalism in France is not a passion, not a crisis, but, as Waldeck-Rousseau put it, a permanent necessity. So far, at least, England and America find it easy to sympathise with the French Republic. No democracy can tolerate the intervention of theocracy in its purely secular affairs. England never brooked Popery as a political power; and the United States would be as impatient of such interference, if it were proved to exist on a national scale, as ever England or France. On this point French Protestants are unanimous, and the great majority of moderate and tolerant Catholics tacitly agree with the great majority of fair-minded free-thinkers. We may reasonably hope that the lesson of the last ten or twelve years, sharp and unequivocal as it was, was not lost on the Catholic Church: 
France will not be governed from the Vatican. This phase of the question already belongs to the past; a few old-fashioned politicians, whose occupation would be gone if Anti-clericalism ceased to be a vital issue, still attempt to raise the cry "Down with Rome!" ; but the echo of their voices grows fainter and fainter. The era of acute anti-clerical strife is closed.

But the question has gone beyond that stage. The Church, her hierarchy, her traditions, her dogmas, have all been drawn into the battle. So freely has her spiritual power been wielded on behalf of certain political parties, that its downfall now threatens to follow theirs. Catholicism, clericalism, reaction, are synonymous in the popular mind. As a result of this confusion, there are signs that the Church is fast losing her hold in France. In spite of the Pope's uncompromising opposition to the Separation Law, the country endorsed the policy of the Radicals. Unable to secure the repeal of that law, Rome attempted to render its application impossible: a few isolated riots, strongly condemned by all reasonable Catholics, and the loss of much property that could easily have been saved, were the only fruit of this defiant attitude. The legal status of Catholicism thus remaining ill-defined, many Churches left out of repair are condemned as unsafe, closed and demolished; there is a movement of protest among artists, antiquaries, and men of letters, but the people as a whole seem indifferent to the slow crumbling down of their ancient places of worship. Have the French peasants fallen into such a state of apathy and torpor that they passively accept whatever order Paris chooses to send them? Not so: the vine-growers' riots in the South and in Champagne, the newly-formed unions of agricultural labourers, show that the "sons of the soil " are more nervously alive than ever before, impatient of the least shadow of tyranny, and all too prompt to action. They deem a label on their wine-bottles worth fighting for-they will not stir their little finger for the Church of their fathers. Catholicism may still claim, nominally, the majority of the French people; the force of habit still leads to the old Church the steps of many passive Catholics who are at the same time active Voltairians : but the old exclusive dominion is gone for ever. France is drifting-or growing-away from 
Rome. The English-speaking nations, still overwhelmingly nonCatholic, have no right and no desire to blame her for that.

But this second stage too is passed. Just as Catholicism was so hopelessly entangled with Clericalism that the downfall of the one threatens to engulf the other, Christianity, in France, seemed so absolutely inseparable from Catholicism that its position has become very critical indeed. It is no secret that in the land of Calvin and Coligny, Protestantism, unchecked by statute or popular prejudice for over a century, has made no visible progress. Most State teachers, the majority of political men, are confessed agnostics; many are blatant atheists and bitter antiChristians. There the Anglo-Saxon public cease to sympathise with the French, and even to understand them. Accustomed, and rightly so, to connect the name of Christianity with everything that is pure, holy, and beneficent, they must find conditions in France bewildering, to say the least. They are not ready to side unreservedly with the Roman Church. Yet when they see an anti-clerical Premier * laughed to scorn in the Chamber of Deputies for daring to repudiate materialism; when they hear a Minister of Labour + applauded for the now historical sentence: "We have extinguished in the heavens lights which shall never" be kindled again!" ; when they are told that the word "God," tabooed from all official documents, is expunged even from grammatical examples in elementary schoolbooks-when they witness such a carnival of impiety, sometimes intolerant, sometimes merely contemptuous, they are tempted to support those who, whatever their faults may be, at least profess themselves Christians. For all this strikes deeper than Clericalism, deeper than Catholicism, to the very roots of Christianity and of religion itself.

One might feel inclined to dismiss the whole problem with a shrug by asserting that infidelity is the unenviable monopoly of small, noisy groups of immoral men and women-a froth that conceals for a while the deep ocean of a people's faith. Preachers will point to the misdeeds of the Boulevard set in Paris and to certain noisome literature only too well known the world over as "French"; and the lesson of the sermon will be

$$
\text { - M. Combes. }
$$

t M. Viviani. 
that wherever men abandon the cause of God, it is because they are eager to serve the devil. As a matter of fact, the Parisian smart set is neither better nor worse than that of other great cities, and is made up of fast livers from the four corners of the world. The yellow-back literature referred to above is concocted by cosmopolitan soul-poisoners for international consumption. Neither has anything to do with free-thought, nor much to do with France as a national entity. The problem is both wider and different. Wider : for apostasy-we must not shrink from an ugly word-is not limited to a thin corrupt stratum in French society : it has spread far and sunk deep. Different: for it is not true that impatience of moral restraint is the sole or even the chief motive of men for throwing off the yoke of Christian theology.

We must needs insist on this point, for no fair discussion of the problem is possible until this dangerous fallacy has been removed from our path. The most outspoken adversaries of the old faith were not "decadent" writers like Bandelaire, Barbey d'Aurevilly, Verlaine, Huysmans : they were lay saints like Quinet, Michelet, Taine, Renan, Littré. There is no more sense in slandering such men as these, even by implication, than there would be in casting a slur on the lives of Darwin, Spencer, Huxley, or John Morley. The adversaries of Christianity are only too prone to seize upon any scandal that may break out in religious circles, and triumphantly to exclaim: "There is Christianity for you!" It used to be an article of faith among a certain class of Voltairians that all priests were tipplers, gluttons, and secretly addicted to all unnatural vices. Let us not retort in the same spirit. Such tactics are to be spurned; with the fair-minded they harm the cause that makes use of them more than the one against which they are directed. Let us frankly recognise, as every thoughtful student of French affairs has repeatedly told us, that neither side has a monopoly of vice or virtue. Renan asserted that he had met none but good priests, and it was a Catholic lady who first called the atheist Littré a saint. Fortunately no elaborate defence of France is required at present: it is no longer the fashion to hold up that country as an awful example for the other nations to avoid. 
Not only the leaders of free-thought in France, but the rank and file of their army, compare favourably with most Churches in the world. The country as a whole, although officially estranged from Christianity, is law-abiding, intelligent, and prosperous. The people are men and women like ourselves, not angels; they show a fine sense of social brotherhood, a disinterested love for justice and truth; their standard of morality-public, commercial, and private-is not lower than our own. In other words, they have undoubtedly preserved the essentials of Christian civilisation, whilst rejecting every article in the Apostles' Creed.

Fanatics the world over denounce fairness to their opponents as high treason against themselves. If we want to understand what people different from ourselves have in their minds and hearts, we should not, before listening to them, brand them as knaves and fools. Science and Christianity alike repudiate such a method. It has been our best endeavour that each rival spiritual scheme stndied in this book be treated with sympathy and with the earnest desire of extracting whatever message it may have for the world. The relation of right thinking to right living and to right believing is still a baffling problem. No doctrine, no example has ever proved to be a panacea; among the Twelve, in the presence of the Master, there was one who fell into the smare. The theory defended by Bourget in his Disciple, according to which a certain metaphysical system, professed by men who are an honour to their kind, is made responsible for the crimes of degenerates, has long been abandoned as a clumsy fallacy. Fairness to all implies the provisional denial of any absolute and exclusive claim : we hope this judicial attitude will not be mistaken for one of secret hostility.

\section{Importance of the Question.}

It is hardly necessary to point out that the religious conditions in France and her spiritual future are of more than local interest. Were the problem purely French in scope, it would none the less be unwise for us to ignore it. The Christianisation of Korea, now proceeding apace, according to the report of missionaries, is rightly considered as a phenomenon of world- 
wide importance, both intrinsically and as a symptom. The alleged dechristianisation of a country which counts for more than many Koreas in the councils of the world deserves our most careful attention.

A time was-not so very long ago-when France held undisputed primacy in civilised Europe, when her language and her philosophy were equally current in every Court and in every salon, when "the world would repeat to-morrow what Paris thought to-day." That time is passed beyond recall. No nation at present is the recognised leader of all. The potency of any example set by France, for good or evil, is thereby greatly diminished. We should not believe, however, that it has become negligible. In mere bulk, if that appeals to certain coarse-grained thinkers, France with her colonial empire still counts among the great nations of the world, ranking next to Britain and Russia, and abreast of the United States. Her intellectual influence on the huge neo-Latin world is still paramount; on the Slavic-another young giant-it is fully equal to any. She no longer is, as her sons boasted of yore, a queen among nations; but, while she ungrudgingly acknowledges many friendly rivals, she recognises no superior.

But the problem is not limited to the territories where the speech of France is understood; it is universal, not national, in scope. The battle raging so fiercely in France is going on, more obscurely, all the world over, in the heart of every thoughtful man. Will Theology stand in the light of modern science? To what extent is Christianity bound to self-styled orthodoxy? Is the future of religion inseparable from that of Christianity? All these questions, debated in secret anguish within many Anglo-Saxon souls, are in France thrashed out publicly, fearlessly, almost recklessly, and the boldest solutions, from which we unconsciously shrink, are not silenced, but applauded on the banks of the Seine. Hence our paradoxical contention that France, famed only as the country of bantering scepticism, is in truth one of the world's spiritual laboratories, where dangerous and possibly useful experiments are being attempted; from the foolhardiness or the heroism, as you may choose to call it, of these daring investigators, we of the more plodding, conservative 
turn of mind may have something to learn. That such fearlessness in the discussion of religious problems has its drawbacks is freely conceded. To put off the cloak of conventionalities and lay their souls bare before a jeering world seems to many a profanation. Religion contains so much that is intimate, unutterable, that no public debate can do it justice. In such matters arguing and criticising will always seem shallow, even flippant, lacking in reverence and in spirituality. The imponderable and yet essential elements of faith baffle the analyst. They vanish in the heat of controversy. What is left is on one side a dead mass of superstitions, on the other incurable scepticism and despair.

On the other hand, the uneasy silence of many among us is not the result of reverence, but of cowardice. And therein lies a danger greater than the first. A belief not openly disputed may degenerate into a prejudice. We should air our inmost sanctuary, else our purest incense will make its atmosphere foul and irrespirable. Worshippers at a sealed shrine, our hearts would be gnawed with the doubt that perhaps the taunt of our adversaries is true, and that there is naught within but a handful of ashes. It is a sickly faith that shuns broad daylight an? needs the closeness and gloom of a cave.

\section{Historical Treatment Necessary.}

This book, therefore, will be not an apology for, but a presentation of the French attitude in religious matters. Our desire, as we have already stated, has been to make this presentation as objective, as dispassionate as possible. This end we could not hope to achieve if we were to describe the present phase of the question. Dust and smoke still cover the battlefield. No man, not even a saint like Littré, a Proteus like Sainte-Beure, an Olympian like Goethe, can possibly do full justice to his contemporaries, because he cannot know their true selves, which time alone reveals. We need a certain perspective, and the collaboration of Death, the appeaser of all vain strife. Another reason makes a historical treatment of such a subject absolutely indispensable. We are dealing with aspirations which are eternal in the human breast; but the forms they 
assume are neither necessary and unchangeable through all ages, nor arbitrary and created anew by each individual. They are the result of tradition, the growth of centuries. The words that a man finds in his heart as if they were a direct revelation imparted to him alone were first spoken generations ago. $\mathrm{He}$ cannot express himself except by reasserting, contradicting, or combining the beliefs of his spiritual ancestors, known and unknown. It is literally true of every religious controversy that among those who take part in it the dead are in the majority, and bolder, louder than the living. Contemporaries of Marcus Aurelius, followers of Ziska or of Loyola, countless disciples of Voltaire are with us in any commonplace-looking assembly of men. The second, the thirteenth, the sixteenth, the eighteenth, and probably the twenty-first centuries jostle one another. Religious conditions in France to-day are what two thousand years have made them.

Is it necessary, then, to retrace the origin of the conflict since the remote days of Clovis, or maybe of Constantine? An alluring task, no doubt, but one so vast that no man could study the whole of it at first hand. The sifting of innumerable details would always be open to the charge of arbitrariness. It would be in every way better to take a late and crucial period, in which all the experience of ages is accumulated, and which contains, so far as we can see, all the germs of present developments. Thus the author thought at first of selecting as his field the nineteenth century, in which all previous history is summed up. Then, desirous of giving at the same time as exhaustive and as definite a treatment as possible, in order to secure the greatest degree of scientific accuracy of which such a study is capable, he decided to limit himself to the period of twenty-two years during which Louis Napoleon, as President or as Emperor, was the ruler of France.

That period is brief; but it was a critical moment in the evolution of religious thought. It saw the fall of the Papacy as a temporal Power, and its exaltation as an absolute dogmatic authority. Whilst Catholicism was making up in internal strength for what it had lost in outward might, Comte, Jittré, Spencer, and the disciples of Darwin offered a complete system 
of the universe on a scientific basis. The struggle between Science and Theology began centuries ago, and the end is not in sight; but never before had the contending parties been more sharply defined, more fully conscious, more powerfully armed. Never before and never since, for the conflict is by no means so intense at present as it was then. All the problems which still vex us, but of which we have grown somewhat weary, were in all their freshness in the sixties. As epoch-making documents, Darwin's Origin of Species, Renan's Life of Jesus, Pius IX.'s Syllabus, have not yet been superseded or consigned to oblivion. But although they are still of living interest to us, the great debates of the time of the Second Empire already belong to history. Forty-two years only have elapsed since the disaster of Sedan; but so complete was the catastrophe, so radical the renovation under the new regime, that the Second Empire seems to stand much farther back in the past. A few protagonists of that period still survive-the Empress Eugenie, Emile Ollivier. They are with us, not of us; they live in their tragic memories. There is a full generation between Taine, Renan, and ourselves. Their books are classics; others, famous in their day, are forgotten. Time has brought its peace to all, and we are now able to enjoy both Victor Hugo and Louis Veuillot without too great a strain. Thus it is possible for us to study the problems of our own time, without bitterness, without passion, in the mirror of history.

\section{Dirision: Theology, Metaphysics, Positirism.}

The Second Empire, as we shall try to demonstrate, was a period of reaction against subjectivism, sentimentalism, and romanticism; such reaction assuming two principal forms, one Catholic, in the name of traditional authority, the other Positivist, in the name of Science. If this definition be accepted, the main lines of our work will be clear.

For the three parts of our book we should like to adopt the names "Theology, Metaphysics, and Positivism." This nomenclature may seem wilfully misleading. It will be noticed, however, that it is borrowed from Anguste Comte, and we shall take these words in the somewhat special meaning that Comte 
gave them. Since such headings are bound to be more or less arbitrary, we have thought that the division made famous by the greatest philosopher of his time would serve as well as any.

The adoption of Comte's key-words does not imply any degree of adhesion to his doctrines, or even to the "law of the three stages," from which they are borrowed. According to Comte, theology, metaphysics, positivism are three successive stages in human philosophy. During the first, man sought to explain the riddles of the universe through the intervention of supernatural powers, recorded in sacred traditions; this attitude is primitive and now outgrown. During the second, abstractions-forces, virtues, principles-the creation of the human mind, were called upon to solve the same problems: a transitional stage, at present nearing its end. In the third-inaugurated by Comte himself, and which is to be final, the facts of nature are allowed to speak for themselves. Perhaps it would be safer to call them "states" rather than " stages" of human development, "faces" rather than "phases" of human thought, for it is possible to believe that all three are legitimate and eternal. There is no doubt as to their co-existing in Comte's time, each deeming itself in the exclusive and definitive possession of truth. All three belong to metaphysics, since all three deal with questions which transcend the physical experience of man; all three are "theological" in their method, for consciously or not, Positivists as well as Christians draw logical conclusions from beliefs accepted as authoritative; all three are positive in their own eyes, since to a Christian the Revelation and his own experiences are facts as solid and plain as any dissection to a physiologist. The essential difference lies in the source of the authority accepted as supreme: in the case of theology, Divine revelation; in the case of metaphysics, human intelligence; in the case of Positivism, the whole of nature viewed objectively.

If we accept these meanings, it will be obvious that all genuine Christians belong to the theological group. Whether they are of the emotional, or of the dry and matter-of-fact type, their final authority is neither in their own thoughts and feelings, nor in the facts of physical nature, but in the Christian revelation. They may never have studied the difficult science called Theology, 
but in the Apostles' Creed and in the Shorter Catechism-in any creed and in any catechism-all theology is contained, as truly as the oak is in the acorn.

By genuine Christians we do not mean all professed Christians. Those for whom allegiance to their Church is merely a habit, a form, or a burden do not belong here. But it is easier in France than in England or America to tell-at least among thinking men-a real from a nominal Christian. So deep and lasting was the influence of the eighteenth century that throughout the nineteenth the pressure of public opinion was often more strongly against Christianity than in its favour. In most cases it required on the part of an educated man a conscious effort to call himself a Christian, whilst it did not take any great originality or heroism to break away from orthodoxy. The most typical Catholics we have to study-Lacordaire, Gratry, Venillot-were converted in their manhood from natural philosophy to the doctrines of Rome: their position was thus unequivocal. On the other hand, the men who abandoned their traditional Church did so with full consciousness, whether, like Victor Hugo and Michelet, they proclaimed their change aloud, or, like Lamartine, Vigny, and even Renan, acted with more caution and reserve. The lingering Christian, who clings to the name because he dares not confess to the world and to himself his own unbelief, exists in France, no doubt; but he is not a legion innumerable, as in England or America.

Another type all too common in our age and country is the man who subordinates his faith to his own feelings and opinions, and calls himself a Christian because the teachings of Christ agree with his own views. In the Protestant world many such men, active, sincere, devoted, still remain within the old Churches either as the "liberal" element, or" engaged in philanthropic work. There is a subtle confusion, sometimes a semi-conscious compromise, between genuine orthodoxy and this veiled form of humanism. In France there is no room for ambiguity. Organised Christianity, both Catholic and Protestant, refused steadily and consistently to recognise "natural religion," for such is the true name of much of our liberalism. On many points it may agree with revealed religion. But there must be 
a final authority: is it the Bible or human nature? When these two conflict we must take our choice. We cannot deny the possibility of such a conflict without making man's conscience a revelation of God's will co-ordinate with the Bible. If such were the case, all sincere books would be Bibles in some degree, all earnest and noble lives would be Messianic. This is Rousseanism, and has no right to masquerade as Christianity. All the disciples of Rousseau, the great Romanticists, Lamartine, Hugo, Michelet, Quinet, were obliged to leave the Church; the Eclecticists, especially their leader, Victor Cousin, strove hard to secure recognition from the Christian bodies, but they sirove in vain. Both supernaturalism and naturalism may be, in their outward manifestations, sentimental, intellectual, or pragmatic; but, in spite of all external resemblances, they are essentially different and can never be reconciled.

By metaphysics we understand the search for ultimate truths through human reason considered as the final authority. This was the attitude of the whole eighteenth century. It implies the denial of any special historical revelation superior to reason itself, although it may assume that reason is the medium for a universal and etermal revelation. Reason, for Voltaire and most of his contemporaries, was an intellectual faculty best exemplified in logic and deductive geometry; for Rousseau the sentiments were the deepest revelation of truth. Intellectualists and sentimentalists, the disciples of Voltaire and the disciples of Rousseau, metaphysicians of all schools, all base their philosophy on human nature. If Kant, the greatest of them, demonstrates, or rather postulates, the existence of God, it is on the evidence of a fact observed in the human heart-the categoric imperative; he merely translates into technical language both Rousseau's ode to conscience and Voltaire's “Si Dieu n'existait pas, il faudrait l'inventer."

The Voltairians slide easily from reason into mere common sense, which leads them to a philosophy stronger on the negative than on the positive side: in a few, atheism of the quiet, lighthearted type; in most, epicurism as a practical rule of life; at best, a cold, attenuated form of theism. Cousin and the Eclecticists add to Voltaire's philosophy some rhetorical warmth 
borrowed from Rousseau and a stronger emphasis on the constructive elements. The Romanticists hold theoretically the same beliefs as the Voltairians and the Eclecticists, except that, in their case, Theism is being dissolved into Pantheism, or pantheistic nature-worship-but they hold them with a degree of enthusiasm and a freedom from cold, abstract reasoning, which gives their best works a deep religious value.

The metaphysical state may not be transitional historically: it certainly is an intermediate or mixed type logically. Some of the men of this group kept in close tonch with Christianity; they retained all its main features except the belief in the historical revelation. At the same time, they were the intellectual sons of Voltaire, the champions of "progress," "enlightenment" ; and they thought themselves imbued with the scientific spirit, called themselves the Prophets of Science. This confusion, at any rate, gave them a wider range of sympathy; Victor Hugo, Lamartine, Michelet were, perhaps, so great as poets because they were so inconsistent as philosophers.

The Positivist-and by this word we mean not exclusively the disciple of Comte, but any man holding a so-called scientific philosophy - the Positivist ignores the claims of certain traditions to Divine inspiration as unproved and unprovable. He considers not only human sentiments but also human reasonings as invalidated by their subjectivism. There are conflicting revelations; there are conflicting philosophies ; their pretensions, all absolute, are mutually destructive. On the contrary, the dispassionate study of facts will lead to reasonably safe and permanent results. Perhaps this method will never be able to answer nltimate questions; if such be the case these questions are, humanly speaking, insoluble. Positivism is not atheistic but agnostic, and even its agnosticism is merely provisional. One cannot prove scientifically that the unknown God is unknowable: such a demonstration is logical, and therefore purely human; in so far as it transcends our experience it belongs to metaphysics. Thus Positivism is a confession of ignorance rather than a solution.

The strictly scientific turn of mind belongs neither to the study of religion nor to that of literature, for it is the negation 
of both. That which interests us is the influence of such a spirit on men whose tendencies were naturally different. Men who were at heart traditionalists, mystics, sentimentalists, or rationalists felt bound to accept the scientific point of view: the result was a conflict between heart and intellect, between aspirations and convictions. Some tried to escape from the problem through the worship of form, of art for art's sake-the most aristocratic brand of opium; some were driven to despair by the contradiction within themselves: Vigny, Leconte de Lisle, Mme. Ackermann, Sully-Prudhomme, Amiel; some attempted to reconcile all opposed tendencies in the synthesis of historical curiosity and sympathy : Sainte-Beuve, Renan. In the problems of practical life, few were tempted by the easy solution of epicurism ; most adopted as their doctrine some form of stoicism, of which Vigny, the greatest of them all, remains the noblest exponent.

Such is our adaptation to the needs of this book of Comte's Three States. We do not mean to defend this classification on philosophical grounds; even if it were much better, it would never be adequate to the infinite variety of human souls and intellects. Its faults are obvious; but it follows the division into schools, sects, and parties that the contemporaries themselves adopted. When it comes to the central problem of their religion, all Catholics stand together-Veuillot, Gratry, Hello, Montalembert, divided in everything else, denounced Renan with equal bitterness. Renan, Taine, Littré, may differ widely ; but, in the eyes of their critics (Caro, Dupanloup, Janet), they formed one group. If this rough classification only saves us a few repetitions; if through comparison and opposition, it helps us to make a few individual characteristics stand out more clearly, it will have served its purpose well enough.

Such therefore is the aim of this study: to interpret for our English and American friends that aspect of French thought which they find hardest to sympathise with. Religious differences, often more apparent than real, are the greatest obstacle to the genuine entente cordiale which ought to prevail between the English-speaking nations and France, their 
sister in liberal thought. Perhaps a frank and dispassionate statement of religious conditions in France, better than any ex parte apology, will help remove a few prejudices. In this hope this work is offered, as a tribute of the author's love for France, the land of his birth, for England, where he grew to conscious manhood, and for America, the home of his choice. 



\section{BOOK I}

\section{CHAPTER I}

\section{A TH OL I C I M}

1. Character and Erolution of Catholicism from 1848 to 1870.

IF, wishing to study the Catholic writers of the Second Empire, we consult that wonderful little book, Lanson's History of French Literature, we shall find: on Lacordaire, a single page; on Veuillot, a single parngraph ; on Montalembert and Berryer, a single sentence of four lines; on de Laprade, a footnote; on Gratry, Hello, Barbey d'Aurevilly, nothing-altogether less than two pages, against a hundred devoted to the free-thinking contemporaries of these men.

We quote M. Lanson because of the excellence of his work and of its representative value. On the whole, M. Lanson is scrupulously fair. He has little sympathy for the cheap Voltairianism of Béranger ; he is rather amused by the philistine "Anti-clericalism" of Augier, or the apocalyptic Anti-clericalism of Hugo, Engène Sue, Michelet. He pays his full tribute of admiration to Joseph de Maistre, and--this is a harder test-lie praises Veuillot sanely, without stint or strain. But Lanson was a Dreyfusist, wrote in Liberal papers, and his testimony might be rejected as tainted with partisanship. Messrs. Brunetière, Doumic, Fagnet, Jules Lemaitre, were or are staunch supporters of the Church, yet they agree, on the whole, with M. Lanson. In the opinion of the best French erities, Catholic literature, in the third quarter of the nineteenth century, counted for very little. 
We must insist, for this opinion is often challenged, although never openly. Brunetière, Lemaitre, Doumic, Faguet, after all, are more or less transfuges and converts, some of them of recent date and of rather doubtful orthodoxy; they were infected with the virus of State education; they cannot fully get rid of their pagan and rationalistic prejudices. In Catholic papers there appears occasionally some dark hint about a whole literature ignored or suppressed by "official " critics and professors; about a vast conspiracy against such historians as Father Goroni, or such philosophers as Blanc-Saint-Bonnet, who ought to be illustrious and are by tacit agreement kept in obscurity; about the necessity of rewriting Petit de Julleville ad majorem Dei gloriam. The hypothesis, like all other tales of mystery, has its attraction. It appeals to one's chivalrous sense of right; and, after all, it is not absurd intrinsically. History has had to be rewritten many times over. The whole of mediæval literature was, for three centuries, misunderstood or forgotten. For Saint-Simon glory began a century after his death; for d'Aubigne, two centuries. Stendhal, writing in the thirties, expected to be understood about 1880-and he was. Joseph de Maistre, hailed as a genius by his partisans in his own lifetime, did not secure universal recognition until thirty years later. In 1860 no critic would have promised Veuillot a permanent place in literature: in 1911 this place is secure for him, a high and a large one. Hello is already more than an "illustrious unknown," and his twilight may grow into a perfect day. Who knows but Blanc-Saint-Bonnet will be remembered when Jules Simon is forgotten?

But, tempting as it is, the theory is baseless. Even priests and prelates-Father Longhaye, a Jesuit, Mgr. Baunard, the President of a Catholic university-fail to reveal to us that mysterious, sacrificed Catholic literature. The same few names are always quoted: Montalembert, Lacordaire, Veuillot-and surely there can be no complaint that these three men were silenced or ignored! The first two were Academicians; they had their hour of popularity and influence; they made more noise in the world than Vigny or Leconte de Lisle. In the case of Veuillot notoriety had to die down before fame could 
rise. But the promised unknown master remains a mysterysome would say a hoax.

As a matter of fact, there is an immense body of Catholic literature never studied by critics, either because it does not fall within their jurisdiction, or, we are bound to say, because it is beneath their notice. Of all books, theological treatises are probably the hardest and most technical, and if the official acts of the Church are generally written with an elegance and majesty unknown to civil documents, their style is so impersonal, they are in every way so closely modelled on traditional types, that only in exceptional cases do they rank as literature. Of sermons there is no end, but-and this is highly to the credit of the Church-they are supposed to derive all their merit from their doctrine and their efficacy, not from the beauty of their form or the personality of the orator. The brilliant discourses of Fathers Lacordaire, de Ravignan, Felix, Hyacinthe Loyson, at Notre-Dame were officially styled lectures, not sermons; they were almost a unique experiment in modern French Catholicism, and one which filled many pious souls with misgivings. Then there are books of spiritual direction and mysticism : they transcend literature. Sainte-Beuve, a sceptic; Barbey d'Aurevilly, a believer, both said, "Where prayer begins, criticism loses its rights."

But there is also the vast, insipid stream of edifying literature published by such firms as Mame or Poussielgue: wellmeant books, some of them ably written-not worse, on the whole, than the average Protestant production of the same kind. We shall have several times to refer to that expressive word "bondieuseries," freely used by such good Catholics as Huysmans and Jules Lemaître. Most foreign tourists, on their way to the Luxembourg or the Sorbonne, have noticed the religious art shops around Saint-Sulpice, with their hideous statues painted in barbaric colours-the shame of a city which calls itself the modern Athens: these shops and their wares are called "bondieuseries." Their exact equivalents exist in literature. Such books seem to reach an immense public. Les Récits d'une Sour, for instance, had a larger circulation than many recognised masterpieces. We must therefore give up the 
hope of discovering a second French literature hidden behind the one we know. If there-ever was any systematic ostracism against Catholic writers it was practised by the Catholics themselves. If Barbey d'Aurevilly, Hello, Villiers de l'Isle-Adam were "excommunicated," as Léon. Bloy* maintains, it was by their co-religionists; not for heresy, but on account of their original talent, distasteful to the Philistine.

What conclusion shall we draw from this undeniable insignificance of the Cacholic element in literature? Not that Catholicism itself was on the wane and a negligible factor in national life; for Catholicism in many ways was stronger under the Second Empire than ever before in the nineteenth century.

The exact number of genuine Catholics at that time is difficult to ascertain; every man who was neither a Protestant, a Jew, nor an open militant free-thinker was supposed to be a Romanist, and the leaders of the party would proudly refer to their thirtysix million French co-religionists. Certain essential ceremoniesbaptism, the first communion, marriage, extreme unction, and burial-retained unshaken hold even of the most sceptical part of the population. Many a Voltairian who would scoff at superstition when the deepest mysteries of the Christian faith were mentioned, would never cut bread without a sign of the cross or have a meat dinner on Good Friday.

The force of inertia kept many a nominal Catholic within the fold: political circumstances artificially increased the number of professed, active members of the Church, for the Church had become identified with social conservation. The Government, with its train of sceptical adventurers and Jewish financiers, was devout-more so than ever was that of Charles X.! Rigorously orthodox too was the saucy, cynical, "smart-set" Press, which so unexpectedly made itself the defender of tradition and dogma against Renan; Catholic also, the old monarchical and Liberal opposition-including Protestants, Voltairians, and Eclecticists-all ultramontane since the days of June; Catholic, the French Academy, which admitted Dupanloup, Lacordaire, Gratry, because of their sacred character, and de Falloux, Montalembert, on the strength of * Léon Bloy, Un Brelan d'Excommunies. 
their services to the Catholic cause. But many of these political converts were hardly Christian at all. Probably at no time during the nineteenth century were active Catholics a majority in the country.*

But they remained none the less incomparably the greatest religious power in France. They alone had a doctrine, a tradition, an organisation. Their opponents were individuals, or small groups of individuals, with hardly a principle in common. The mass of the people was amorphous and fickle then as now. And if among the large and strong Catholic minority there were superstitious peasants and self-seeking politicians, there were also heroes and saints whose names do not belong to literary bistory and are too often neglected; there were such fine types of middle-class usefulness and virtue as Cochin and Bonjean, of brilliant, unselfish service both to higher education and to the poor as Ozanam, of total devotion to charity as Sister Rosalie, of saintliness in humble guise as J. B. Vianney, the famous vicar of Ars.

A large, powerful body, this is plain ; a comparatively poor literature, this is hardly less certain; the discrepancy is striking and remains to be explained. It would be ridiculous to ascribe it to the very essence of Catholicism ; in the country of Pascal, Bossuet, Fénelon, Chateaubriand, submission to the Church and literary genins are surely not incompatible. The reactionary spirit, it is maintained, paralyses intellectual activity; but, half a century before, reaction had led to a splendid revival of Catholic literature. Why did not the Second Empire have its Joseph de Maistre and its Chateaubriand? Why did all the masters of French thought sever their connection with Rome instead of joining in the chorus of praise, as under the Restoration? Why was there among the Catholics themselves such an attitude of uneasy, quarrelsome conservatism instead of the joyous confidence, the assertive leadership of old? Some lowering, weakening, materialising influence must have been

* Cf. Taine, Les Origines de la France Contemporaine, xi.; Le Régime Moderne, iii.; L'Eglise, p. 183 ; notes and documents of ccclosiastical origin. According to his estimato, one woman in four, ono man in twolve, aro "practising" Catholics. 
at work. The Church represented no longer purely an ideal, but also vested interests. We must dwell for a moment on this regrettable transformation.

In 1846 Pius IX. became Pope, and from his accession he showed such liberal tendencies that Metternich and Guizot shook their heads disapprovingly, and that the golden prospect of a reconciliation between Catholic traditions and Democracy seemed brighter than ever. When the Revolution of 1848 broke out, this wave of confidence and enthusiasm was still strong; the people, so violently hostile to the priests in 1830, respected them in 1848; the clergy blessed the trees of Liberty. In Rome the Pope granted a constitution, and was already hailed as the future president of an Italian Confederacy and the head of the democratic party. Within a few weeks conditions changed radically. Whilst "the days of June," frightening the French middle class, gave the ascendancy to the most conservative elements, Roman affairs were taking a revolutionary and tragic turn. The Pope dismissed his liberal ministers and called to power Rossi, a man of cosmopolitan experience and unusual ability. But skilful though he was, he found it well-nigh impossible to steer between the retrograde pontifical court and the democratic populace. On the 15th of November he was murdered by the mob ; the Pope fled to the kingdom of Naples, and in February, 1849, the Roman Republic was proclaimed.

Thus, by the begimning of 1849 , a peaceable settlement of political and social conflicts had become impossible, and no doubt could be entertained as to which side the Chureh would take. In the first place, Conservatives and repentant Liberals rallied round her, becanse, every other authority being ruined, she alone represented tradition, organisation, power. Liberal Catholicism was swept away. In spite of all their fame, Montalembert and Lacordaire had never been whole-heartedly supported by the bulk of their co-religionists, in whose eyes liberty remained a dangerons Utopia. Had the Liberals been stronger in number, influcnce, or conviction, they might have acted as mediators and tempered the violence of reaction. But some wcre afraid, and found it necessary to leave their Liberalism in abeyance; the rest were distrusted and powerless. Then many 
came sincerely to believe that Socialism and Religion were incompatible. The days of June were considered as an explosion of envy, hatred, material appetites; the songs in which the Democrats claimed Jesus as their master were denounced as blasphemous. Had not one and the same man, Proudhon, written the two formidable aphorisms, "God is Evil" and "Property is Theft"? Was not the motto "Neither God nor Master" ascribed to Blanqui? Finally, although the question of temporal power was not, strictly speaking, a religious one, it was difficult for Catholics to separate the cause of Pius the King rom that of Pius the Pope. French democrats were logically bound to support Mazzini and the Roman Republic; Catholics were no less naturally obliged to side with their Pontiff and against revolution. God, the Pope, property, law and order were all attacked by the same enemies ; practically all Catholics became reactionaries, and all reactionaries, whatever their private beliefs, stood as defenders of the Pope and the Church. The Romanticists, in the early part of their career, had been the "Knights of the Throne and the Altar" ; the battle-cry of the new crusaders was "The Pope and Property."

In the Catholic Church and party, therefore, religion became inextricably entangled with purely material interests: the defence of private property against Socialism, the defence of the temporal power against Roman revolutionists and Italian patriots. Louis Napoleon, as President and as Emperor, undertook the double task of saving society and the Pope. The Catholies could not deny him their support; Veuillot, and, after some hesitation, Montalembert himself, advised their co-religionists to condone the coup d'état. Thus was the alliance sealed; the presence of a French army in Rome remained its sign.

'The Pope became more and more the master of the situation ; his temporal power stood as the symbol of all conservative interests; his spiritual authority was more and more recognised as absolute. Every revolution, even when it harmed religion or the Church, had scrved the Papacy. The Gallican spirit succumbed with the old monarchy, had a faint revival under the Restoration, and finally died after 1830. When the King was 
the successor of Clovis, the descendant of Saint-Louis, the eldest son of the Church, his power could balance, even in ecclesiastical matters, that of the Pope himself. But who could accredit any authority in religious affairs to Louis-Philippe, the Voltairian, King by the grace of the barricades? When Lamennais transferred his allegiance from absolutism to democracy, he became at first more ultramontane than ever; the continuators of his work after his schism were as decidedly antiGallican as they were liberal. The influence of Joseph de Maistre * was steadily growing. His book on The Pope was no longer taken as a brilliant paradox, but as a political and ecclesiastical gospel. The "Prophet of the Past," as he was styled, was becoming a prophet of the future. The Pope, materially helpless against revolution and conquest, was all the more blindly and lovingly obeyed by his followers. No one would be so ungenerous at such a time as to add to his difficulties and sorrows. All dissent, all opposition within were silenced. Ultramontanism was triumphant. In 1854, the proclamation of the dogma of the Immaculate Conception by the Pope, alone and on his own authority, was a practical assumption of infallibility; in 1870 the Vatican Council made infallibility a dogma.

The power thus attained was used by Pius IX. with remarkable singleness of purpose for a war on modern civilisation and its idols_- "liberty" and "progress." The European upheaval of 1848 and his own tragic experience had filled him with horror for the Revolution, and for democracy and free-thought as the instruments and ideals of the Revolution. This humble country priest, as he liked to call himself, a man of simple tastes and a kindly, cheerful disposition, assumed as Pope a sombre grandeur which impressed even his enemies. He was the representative of authority-the sole authority not of human origin but divinely ordained. All other powers were either his vassals or the creatures of revolution. He alone had principles to oppose to those of 1789, and he proceeded to assert them through his semi-official paper, La Civiltà Catolica, and in his apostolic and encyclical letters, with the fearlessness of a mystic. Finally, he

* Latreille, Joseph de Maistre et la Papauté. 
had a systematic catalogue or Syllabus drawn up rehearsing all the errors that he had previonsly condemned (1864). In its negative and theological form this famous document may be interpreted in several different ways. MIgr. Dupanloup's clever attempt to explain it away was commended by the Roman court itself. But Ultramontanes and free-thinkers alike took it literally as an open declaration of war. Whatever may be its orthodox interpretation-and there seem to be several, all authorised by the Church - the impression on public opinion was unequivocal; the Syllabus was summed up in its eightieth and last proposition: "Anathema on him who ever should maintain "that the Pope can and must be reconciled, and compromise with progress, liberalism, and modern civilisation.'"

In short, Catholicism, under the Second Empire, was influenced by four principal factors : at home, its alliance with political and social reaction; in Rome, the bitter memories of 18 18 , and anxieties as to the Pope's temporal power; the growth of Ultramontanism, culminating in the proclamation of papal infallibility; finally, the thoroughgoing, fearless character of Pius IX., which precipitated and intensified conflicts which a Leo XIII. might have averted.

Hence the general tone of Catholic literature, in which a spiritual note was at that time surprisingly rare. Veuillot, a pitiless, unscrupulous fighter, jeered at the "Charitans," Montalembert and Dupanloup, who censured his bitterness as unchristian. But they, although less coarsely aggressive, were hardly more charitable than he. In their works, under a film of traditional unction, there prevailed a hard, unsympathetic, materialistic train of thought. This was the result of the temporal preoccupations in which the Chnreh was absorbed, and of her open conflict with modern aspirations. The Empire built magnificent churches everywhere, and gave Cardinals a seat in the Senate. But for all this outward power and splendour, it was one of the darkest periods in the history of French Catholicism.

2. Asstheticism in Religion: the Satanic School.

Of the two great Cliristian apologists in the beginning of the nimeteenth century, Joseph de Maistre was the apostle 
of authority rather than of spirituality; Chateaubriand was an artist and a sentimentalist, for whom the deep tones of evening bells, the mystic twilight of a Gothic chapel, the noble melancholy of a ruined cloister, were all-conquering arguments. Absolutism and rstheticism combined at first in the faith of all the great Romanticists, although with them the influence of Châteaubriand was paramount. After 1848, however, Absolutism, the gospel of authority, became, as we have tried to show, the dominant factor in French Catholicism. Napoleonic despotism and papal infallibility were supported by Veuillot, Barbey d'Aurevilly, and even, for a moment, by the pseudoLiberal Montalembert. Astheticism, the cult of beauty, had seceded. It was in democracy, not in the Catholic Church, that Michelet and Hugo now sought their inspiration; and the men who, under the Second Empire, had the keenest sense of beanty in religious matters were Leconte de Lisle, a rabid antichristian, and Renan, in whom the Church recognised her subtlest and deadliest foe.

Great as the influence of Le Génie du Christianisme may seem to have been, it was probably never very deep. By 1848 all its force was spent. Chateaubriand himself allowed his scepticism and disenchantment to be surmised under the noble cloak of his orthodoxy. With genuine Catholics a faith based on sensuousness and sentimentalism was discredited: it had led astray all its most famous adepts. For the rising generation of realists and positivists, it embodied all the faults of Romanticism-vagueness, arbitrariness, subjectivism. For pure artists it had come and gone, like any other fashion: after Chateaubriand, Lamartine, Vigny, Hugo, Catholicism had become a hackneyed theme, good enough for provincial poets, like Laprade, Rebonl, and Brizeux. Jocelyn was perhaps the last great success of sentimental Catholicism-but it was already verging on Rousseauist religiosity. La Chute d'un Ange, which appeared soon afterwards (1836), was a failure. Soumet's Divine Epopée was voted to be tedious. Hugo was sketching the portrait of his ideal-and real-Bishop Myriel; but he did not publish it until 1862, in Les Miserrables, and then deftly trumed it into an apology of humanitarianism and a satire on 
the modern clergy. The cult of beauty no longer led to Catholic altars.

Or, if it did, it was through strange and devious paths. To the Seraplism of Lamartine and Vigny, all purity, all harmony, succeeded the Diabolism of Baudelaire and Barbey d'Aurevilly, a compound of mysticism, lubricity, and pathology. But both the white flower and the morbid growth were natural offshoots of Le Génie du Christianisme. Sentimentalism in religion is ever a dangerous thing; but when it is intensified by literature, it leads straight to-the devil. For the devil is good literature, the angels are not. $\mathrm{He}$ is human through all his faults and sufferings: they are beyond the scope of our imagination. Then there lurks in all of us a secret sympathy for daring rebels: Prometheus, Satan, even Cain ; cold, submissive perfection we cannot endure. Even in Sunday-school books the bad little boys are generally more attractive than the good ones. On the heroic scale we find that Milton's angels of darkness are singularly more vivid than their pure and glorious brothers. Vigny's Eloa falls an easy prey to the charms of Satan. Much of Byron's success was due to his attitude of defiance and revolt. If the devil had not existed, the Romanticists would undoubtedly have invented him.

Innocence, from the literary point of view, is insipid. In France, its vogne will never last long. The French would rather boast of imiginary crimes than pose as more virtuons than they are. It was throngh their failings even more than through their noble qualities that the Romanticists could expect to retain the attention and sympathy of the public. Chateanbriand tanght them the possibilities of sin. Mere guilt wonld pall on the taste almost as rapidly as innocence itself. Guilt, on the ordinary plane, is simply vulgar; and when it is not commonplace and half-hearted, it is brutal: a genuine criminal, after all, is an uninteresting personage. But religion transmutes guilt into sin; it gives it a place in the great drama of the nniverse; it provides a foil for it, enhances its value, intensifies remorse, creates an admirable contrast between our abjectness and our aspirations. So Chateanbriand, the archsentimentalist, posed as though, through some unutterable 
crime, he had incurred a mysterious curse. Byron, whose influence was second to that of Chateaubriand alone, was less subtle because he was less orthodox; but he too managed to use mysticism as a means of heightening the terror, the remorse, and thereby the "interest" of sin. The French Romantic poets were law-abiding citizens, whose most heinous crime against society seems to have been slackness in their duties as National Guards; yet most of their heroes-Hernani, Didier, Antony - "bore the fatal sign on their pale brow." René, Manfied, and their progeny were already Fleurs du Mal and Diaboliques.

As for the weirdness, so striking in Barbey d'Aurevilly, and which Baudelaire was long supposed to have borrowed from Poe, it was also one of the elements of early Romanticism. The taste for the supernatural began far back in the eighteenth century. Much of the favour enjoyed by Hamlet and Faust was due to their elements of mystery and terror. Hoffmann's tales had a wider and more lasting popularity in France than in their own country, and so widely read and admired was Melmoth the Wanderer that Balzac himself wrote a Melmoth réconcilié. The great vogue of the Middle Ages brought witcheraft and demonology into favour. Even such a sunny, healthy pagan poet as Gantier cultivated, fifteen years before Baudelaire, the morbid and the uncanny.

Mysticism and ter"or are blended in the "Diabolic" school with love, or rather with sensuality. This combination is by $n$ means modern. Baudelaire himself dated it back to the last days of the decadence of Rome: "Mysticism is the other pole of that magnet of which Catullus and his band, poets whose love was simply brutal and skin-deep, had known only the pole 'sensuality.'" Long before the publication of Michelet's amusing and highly romantic Sorcieve (1862), the alliance of demon-worship and debauchery in witchcraft was a commonplace of popular history. And not only the Spanish mystics with daring crudity, but even the French Quietists, had systematically interchanged the vocabularies of spiritual and earthly love.

The fondness of the Diabolists for physiological details of a 
harrowing nature-wounds, sores, diseases, and "ce je ne sais quoi qui n'a de nom dans aucune langue "-is another familiar feature of orthodox Romanticism. The hospital, the charnelhouse, and the grave were favourite themes-even with Gautier! Hugo described monsters and tortures with visible gusto; Mérimée, in his coolest, most dispassionate tone, loved to relate blood-curdling stories of suffering and death. Dumas, kindly and childlike, took pride and pleasure in exhibiting physical pain on the stage (Henri III. et sa Cour, Christine, etc.). The poems of Sainte-Benve read at times like versified clinical reports.

Baudelaire and Barbey d'Aurevilly, therefore, did not have the cheap merit of originality. They were belated stragglers of the great Romantic army, not renovators or initiators. Needless to say that there is more in them than degenerescent Romanticism-than self-conscious, carefully cultivated morbidity. Else their names would be forgotten, like so many others, in a dark corner of the Romantic musenm. Such is not the case: their fame is alive to this day. Even at their worst, ther are interesting as extreme types of certain sentimental and spiritual deformations.

It is difficult to determine the limits of Bandelaire's sincerity. The Flowers of Exil is not a straight confession-that much is certain. There is a Bandelaire legend-that of an eccentric, half-crazy personage, subtly corrupt, addicted to poisonous drugs and monstrous vices. The poet resented this opprobrious legend; but, impelled by his inner demon of perverse mystification, he could not help encouraging its growth. It had some slight foundation in fact: not enough to give The Flowers of Evil the value of a clinical document. It is not a scientific study either. This was Baudelaire's specious plea when the book was prosecuted. But the very title is antiscientific: it implies a double judgment, one of moral reproof, the other of esthetic admiration. His daily life was not pictured in his verse; his whole soul was not in his work, but his imagination at least was there. His poetry was the mirror of his dreams.

Now, to Baudelaire, the dream-life meant more than to many 
of his healthier, happier contemporaries, Cramped in his material circumstances, isolated in his pride, " yawning his life" like Chateanbriand, he sought a refuge in "the ideal," as he chose to call it, and when he came into contact with reality, he used it only as a stuff to make dreams of. Thus it became impossible to disentangle his fancies from his true self. They were unreal, and yet the only reality he cared for. His poems were a pageant which he gave to charm the ennui and solitude of his soul, and the pageant became his very soul. The identity between the man and the work grew to be so complete that he had to write: "Must I tell you, you who have not divined it any more than the others, that in this atrocious book I have put all my heart, all my tenderness, all my religion (travestied), all my hatred? It is true that I shall write the reverse, that I shall swear it is purely a work of art, a piece of mimicry and jugglery-and I shall lie like a charlatan." *

That dream-life of his was coloured by his own sad experience and by his intense desire for originality. Heredity, failure, disease, had made him morbid; the influence of low Romanticism fixed vague tendencies into a permanent, semi-conscious attitude; pride songht for this attitude a philosophical sanction. The beauty of sanity and harmony came to strike him as offensively vulgar. Goodness and truth were good and true enough for the "modern rabble" he so thoroughly despised. All religions of healthy-mindedness, optimism, progress, nature, were hateful to him. Catholicism was at hand to provide him with a doctrine. As a man, as an artist, as a thinker, he found satisfaction in the more sombre aspects of its mysticism and theology. 'The doctrine of total depravity, the corruptedness of the flesh, the constant presence of the enemy, the haunting fear of death and of eternal punishment-he needed such notions as these for imparting to his fancies the haut-gout he was craving for. At the same time, their spirituality gave them distinction, kept them far above the brutal pessimism of materialists like Taine. Theological and ecclesiastical terms and images are constantly found in his poetry: angels and demons, sin, hell, damnation, sacraments, priests, monks, bells, cathedrals, incense, 
ex-voto. This is not a mere literary trick, but the expression of his habitual train of thought. To Flaubert he wrote: "I cannot. . account for certain sudden acts and thoughts of man, without the hypothesis of the intervention of an Evil Power not in himself." * "All heresies are but the consequences of the great modern heresy-the artificial doctrine substituted for the natural doctrine-I mean the sippression of the doctrine of original sin." +

But the Catholic poet remained, first of all, a seeker after sensations and a sentimentalist. He was not satisfied with the mere description of sin and its horrors; he must needs taste and analyse the enjoyableness, the fascination of that very horror, the flower of evil: "The charms of horror appeal only to the strong." † The libertine, yearning insatiably for the obscure and the uncertain, loves his own hell.\$ Pride in one's own reprobation takes the place of remorse. Conscionsness in doing evil is "the last relief, the sole glory" of the sinner. gives himself the illusion of a free choice, and even in spiritual disaster remains the captain of his soul.

Systematic depravity could go no farther. Dowmright blasphemy would not make matters worse. On the contrary: whoso takes pride in evil must not obscure the distinction between good and evil, else his perversity would lose much of its zest. The three pieces entitled Révolte are not in harmony with the true Baudelairian spirit. 'They proceed from the assumption that Satan and Cain were "wronged," that there is, as Vigny said, a great historical case to be judged anew before the court of our conseience. Such a view is an unnatural, inverted form of moralism, a paradoxical but gemuine craving for justice and truth; it may be depraved, it is not perverse. Baudelaire affirmed that these three pieces were mere pastiches; and it seems safe to accept his word for it.

Sainte-Beuve compared the Flowers of Evil to a nightmare, to a temptation of St. Anthony, just before the cock crows and the sleeper wakes; these feverish, disordered fancies would soon be dispelled by the light of day. But this, to Sainte-

* Corr. $268 . \quad \dagger$ Ibid. 85.

$\S$ Ibid. 207. $\ddagger$ Fleurs du Mal, 278.

II Ibid. 244. 
Beuve's regret, the reader was not made to realise. The great critic himself had known morbid hours and outlived them: Consolations had followed Joseph Delorme. But Baudelaire's imagination was one-sided and wholly diseased. He never woke to normal life again, as Goethe did after Werther. Yet there are in his poetry notes which seem to herald the dawn: all too few, but all the more precious. Such are:-

"Through the operation of some avenging mystery

In the slumbering brute an angel awakens";*

and the closing lines of Le Voyage à Cythère:-

"Ah, Lord! give me the force and the courage

To contemplate my heart and my body without disgust." $\dagger$

In these outbursts of remorse, Baudelaire rivals Verlaine at his best. A few more such touches, and he would have made good his claim that the Flowers of Eril is " filled with ardent spirituality."

As it is, the book is a remarkable feat of poetic skill; it has psychological merit and even some moral interest; but it does not ring true as religious literature. Its intermittent sincerity is smothered by downright affectation, sensationalism, and sentimentalism; in its mixture of mysticism and sensuality, the latter is evidently the predominant element. A faith used for adding spice to lustful pleasure must be of a very equivocal character. Catholicism was for Baudelaire a good working hypothesis; had Pantheism inspired him with more enjoyable dreams, he would have adopted it with the same degree of semisincerity. $t$ And his final religious opinions are perhaps truly expressed in this passage: "When I am absolutely alone, I shall seek out a religion, Tibetan or Japanese-for I despise the Koran -and at the time of my death I shall abjure this last religion, in order to show clearly my disgust for universal stupidity." $\$$ Yet Baudelairianism is not essentially different from the

* F. du M. 154. † Ibid. 321-cf. also L'Examen de Minuit, 218. 
religious attitude of Chateanbriand or Lacordaire. When the author of poems censured for their immorality aspired to the succession of the ascetic Dominican friar in the French Academy, this was considered even by his friend Sainte-Beuve as a piece of impertinence and studied eccentricity. There is no reason to believe that Baudelaire was not in earnest. As he wrote to Alfred de Vigny, there were between Lacordaire and himself two bonds of kinship: Christianity and Romanticism.* Esthetic sentimentalism in religion has its seamy as well as its glorious side, and they are not so far apart as one would imagine.

Bandelaire is the best known exponent of depraved Catholieism. He was neither a great thinker nor a supreme artist; Barbey d'Aurevilly was better informed, as keen an obscrver, and a more productive writer. But Bandelaire never left his own narrow field, and he showed in it a rare power of poetic concentration. There were half a dozen men in Barbey d'Aurevilly, and for that reason he remains to this day one of the "illustrious unknown" of French literature.

Like Bandelaire, he had his legend. The theorist of Dandyism, the enthusiastic biographer of Beau Brummel, the belated Romanticist who at seventy sported in Paris his lace cuffs, his gold-braided, tight-fitting trousers, his hat lined with red velvet, with the swaggering grace of a musketeer and the gravity of a prophet, was considered as a hoary child, a harmless lunatic, one of the amusing curiosities of the capital. Those who knew him better added that he was a "pyrotechnic" conversationalist; his irrepressible and paradoxical fancy would take the form of mexpected and dazzling images, which went sky-high and left night darker. He was also reported to be a staunch believer in the existence and influence of the Devilperhaps a Devil-worshipper himself, a seeker after strange sensations, who would fain discover an eighth capital sin. A thorough gentleman withal, a model of unfailing kindness and old-fashioned courtesy, and, for all his Dandyism and Satanism, his coruscating and truculent wit, as simple as a child. 
Baudelaire admired his first novels-Une Vieille Maîtresse, L'Ensorcelée - which indeed, several years before the publication of the collected Fleurs du Mal, offered the true Baudelairian compound : vice and crime with a dash of mysticism. The tales Les Diaboliques (published 1874) belong even more strikingly to the same school. Barbey revels in descriptions of sin, perversity, demoniacal possession. Yet Diabolism, like Dandyism, is only one aspect of his talent, and should not be unduly cmphasiser. Barbey differs from Baudelaire in many respects. thirst of all, he is openly, almost blatantly orthodox-and his religion is not so much a part of his literature as of his politics. Baudelaire invoked de Maistre, but he was pre-eminently a sentimentalist, a disciple of Chateaubriand. Barbey is a much more consistent advocate of the principle of authority, a more genuine follower of de Maistre. Then, although he probably believed in the Devil, he did not bind the fate of his novels and tales to such belief; every incident could be explained without the intervention of a personal Prince of Darkness. "Diabolism" is rather a spice than an essential ingredient in his works. Without it they would retain their value. Perhaps they would be more seriously considered and better appreciated. For he has many romantic qualities-spirit and colour, for instance, with a new touch of intense local realism. He is the Homer of the Valognes district, supreme in his little realm, and thereby precious for all times. Let us hope that the satanic dandy Barbey d'Aurevilly will not be forgotten, for he is a picturesque and harmless figure; but let us also hope that he will no longer obscure the tormented, lop-sided, intemperate, and powerful novelist of Le Chevalier des Touches.

Baudelaire and Barbey d'Aurevilly did not form a school; yet it would be an error to believe that they exhausted the possibilities of Romanticism, depravity, and Catholicism combined. This kind of literature kept its morbid fascination, even after the excesses, the scandal of the Flowers of Evil and their cheap vulgar imitations. Barbey d'Aurevilly lived until 1889; this patriarch of parodoxical orthodoxy saw several generations of Baudelairians. He knew their common ancestor, Chateaubriand; he influenced, criticised, defended Baudelaire himself; he read 
Villiers de l'Isle-Adams's pages of mystic and savage irony,* and Verlaine's poems of corrupt love and child-like faith, alternate or parallel ; he corresponded with Léon Bloy and foretold to Huysmans that $A$ Rebours would lead him to $L a$ Cathédrale. Baudelaire's spirit extended its influence afar, and that influence is still with us: it inspired several of Swinburne's poems, † tainted for a while Macterlinck's true nobleness of soul, and in the guise of Wilde's Salome assumed the proportion of a world-wide disease. +

\section{The Gospel of Authority: D'Aurerilly and Feuillot.}

Thus the spinit of Chateabriand, perverted, but still recognisable, lingered in French literature. The influence of Joseph de Maistre operated in a very different mamner. Outwirdly, his rigid system had under the Second Empire a much more potent action than the vague and subjective religiosity of Chatembriand. Even Bandelaire, who songht in Catholicism only sensations and images, and who was totally indifferent to the destinies of the Church, disowned his romantic filiation, and professed the warmest admiration for de Maistre the Seer. History, as interpreted by the Conservatives, seemed to support de Maistre's main contention and to verify his prophecies. Ne stable society without religion, no religion without a Church, no true Chureh but the Roman Catholic, and no genuine Catholicism without an infallible Pope: such was the gist of his teaching. It was necessary to restore the principle of anthority-but only one authority claimed to come directly from God and showed historical permanency. Theocracy was the only alternative to revolution. A reaction would have taken place, no doubt, even if de Maistre had never written a line. But his books prepared men's minds for it. A sort of dogmatic anthority was ascribed to his writings: for they provided the Conservatives with what we are all craving for-principles in accord with our interests and passions, a theory that iustifies our practice. De Maistre

* Tribulat Bonhommet.

+ Dolores.

$\ddagger$ Salome is perhaps the masterpiece of Baudelairianism, the fullest-blown flower of evil. Baudelaire's Une Martyre is not so complete, because it is not connected with sacred history. Cf. also MI. Rollinat. 
was given the title which he had attempted to wrest from his great Gallican adversary, Bossuet: he became the "last Father of the Church."

But however great his favour and even his real influence on the Catholic world, * his direct action on literature was small. Only two writers of note, Barbey d'Aurevilly and Veuillot, were unquestionable disciples of de Maistre, and even in their case it is difficult to tell how much they received directly from him.

Barbey d'Aurevilly, as a political and religious philosopher, was never taken seriously: Louis Venillot was perhaps taken all too tragically. A virulent, unsparing polemist, admirably fearless, but excessive and unscrupulous, he had a marvellous gift of righteous indignation and vitriolic expiession. His hand was against every man, and every man's hand against him. No man was more ardently hated, more vilely insulted-not even the Emperor himself. Victor Hugo would repeatedly divert the torrent of his invective from "Napoleon the Little" to the Catholic journalist. Emile Angier made him the invisible centre of his satirical play, Le Fils de Giboyer. His name caused Montalembert, his nominal leader, to lose his aristocratic self-possession. Scherer, the grave, learned, somewhat ponderous critic, was never so near raving as when he reviewed Les Parfums de Rome and Les Odeurs de Paris. Even Dondan, the gentle ironist, spoke of him with unwonted bitterness. Only Sainte-Beuve, myriad-souled Sainte-Beuve, was able to judge the monster judicially.

The doctrines which he defended with such uncompromising energy were apparently those of Joseph de Maistre. Like de Maistre and Barbey d'Aurevilly, Veuillot was a blind believer in the principle of authority, as opposed to the principle of revolution. Human nature is corrupt; what it needs is not freedom, which leads only to evil-not education, which implies the existence of good germs to be developed-but discipline, repression, and the sterner the better. We need an authority from above, from without, to help us conquer our evil instincts. Protestantism and Philosophy compromise with the enemy, the

* And even outside: some of his theories combined with those of SaintSimon in the mind of Auguste Comte. 
natural man; they tolerate or even praise individual interpretation, autonomy, liberty-but liberty means anarchy and dissolution. The Catholic Church alone claims and exercises absolute spiritual anthority. She alone stands ou the side of God, against the first Revolutionist and his innumerable followers, loose-livers, free-thinkers, and Protestants.

Veuillot was a thoroughgoing theocratist, like de Maistre. Papal infallibility was one of his dearest beliefs; its proclamation in 1870 gave him one of the greatest joys in his life. Like de Maistre also, he hated more than heretics or free-thinker's those orthodox Catholies whose obedience to the Pope was not unconditional. Gallicans, Liberals, were in his eyes traitors, enemies within the gates.

After Joseph de Maistre and with Barbey d'Aurevilly, he defended Catholicism in an aggressive manner, sombre and scornful at times, then airy, flippant, sarcastic, always very different from the calm dignity of the older apologists-the majesty of Bossuet, the unction of Fénclon.* These modern champions of orthodoxy and discipline affected in their method the dash and irresponsibility of free-lances. They were called the Bashi-Bazouks of the Holy See. They did not balk at invective; they indulged in pleasantry, and revelled in paradox. They would play endless variations on the theme "Credo quia absurdum," thus sending the Voltairians into fits of impotent rage. Many good Catholies defended the Inquisition, the Jesnits, modern miracles, in an embarrassed, half-apologetic manner: then it was that Venillot loved to display his defiant orthodoxy. It was his prineiple never to yield a point to the enemy. If his contention was weak, it had to be reasserted with increased energy; if totally indefensible, the aftirmation ought to be all the more enthusiastic and trenchant. We can see this method and this spirit at work in the famous apology for dirt: "The empire of the world belongs to the dirty nations. ... All those who love cleanliness are weak. And it must be so. Whatever they say, the human body is but dirt. God made it out of mud; naturally it can find no strength except in its

* They might have claimed as their model Pascal, not only in his Provinciales, but even in his Pensées. 
component elements. The soul, of course, must be clean! Born of the breath of God, the soul is purity itself, and lives on purity alone. But this is the great evil: all luxuries for the body paralyse and betray the soul. . . The Muscovites may conquer the world: their triumph depends not on their progress in civilisation, but on the strength and duration of their appetite for tallow." * This passage of course is full of humorous exaggeration, although Father Longhaye, like many less orthodox critics, seems to take it seriously. But it is the only answer offered to a very serious objection (the inefficiency of the Papal Government in sanitary matters), and it contains a dangerous mixture of paradox and earnest faith. The new apologetics may provide easier reading than the old, but will hardly be considered more convincing.

But it seems as though Veuillot did not care to convince any one. The nature of his faith and his temperament made him the reverse of a missionary. His faith was so absolute that, forgetting he was a convert himself, he came to think that everybody knew where the truth was; pride, cowardice, perversity alone deterred people from confessing with their lips what they believed in their hearts. There are no genuine unbelievers: there are only personal enemies of God. Whoever, in a Christian land, is not a Christian (i.e., an ultramontane Catholic), is, not a soul in darkness, to be pitied and enlightened, but a fool and a scoundrel. The theory, monstrous as it may seem to the lukewarm, is yet logical enough. When the Gospel is preached to sane and moral men, and is refused by them, there can be only two alternatives: either wilfulness on their part, for which they are responsible in this world and in the next, for it is the sin of man ; or spiritual blindness, lack of grace, for which they are not morally responsible, but God Himself. The second hypothesis is in many respects more dangerous, more monstrous than the first. If unbelievers are not rictims, they are criminals.

Veuillot had not patience with the "Charitans," as he called them, the Catholics who urged him to be patient and gentle with his enemies. No truckling to vice! and heterodoxy was

* Les Odeurs de Paris, 438. 
essentially a vice. He loved his enemies, he thought, as the shepherd's dog loves the sheep. He was commended of the shepherd: * his conscience was at peace.

The intolerance born of his umreasoning faith was made worse by the intemperance resulting from his early training and the nature of his life's work. Veuillot was a man of the people. His father was a cooper. His own education was neglected. At an early age he was allowed to read licentious eighteenthcentury novels which could improve neither his taste nor his morals. Later he bccame a clerk at a notary's, and before he was of age he was already engaged in active journalism. Years of patient self-culture and the experience of a varied life could never make up for the want of sound training and refining influences. It was perhaps ungenerous and pedantic of Scherer, a great scholar himself, to tax Venillot so severely with his ignorance: at that time, Veuillot had a multitude of facts at his command, but the critical spirit he never acquired; he was a master of French prose, direct, personal, racy, popular, and yet in the best classical tradition-but "taste" was a word he could not understand. In controversy he despiser', as insincere and faint-hearted, the courteous fencing of gentlemen and scholars: strong words and good hard blows were his method of settling a quarrel.

A quiet, disinterested occupation might have subdued the vulgarity of his temperament, but he left the drudgery of officework for the fever of journalism. A journalist he was from first to last. As a poet he was generally mediocre; as a norclist he is forgotten even by the very special public for whom he wrote; as a purely religions writer (Life of Jesus, Meditations on the Rosary, Prayers to the Virgin) he is undistinguished. All his works are either collections of articles (Mélanges) or volumes written in the same tone and the same spirit as his articles. His literary life was a constant battle for forty years: such a life intensified his pugnacity and stunted the growth of his gentler,

* Pius IX., who had much in common with Veuillot, supported him against the Archbishop of Paris and the illustrious MIgr. Dupanloup. His mission in life, he said, was to make the persecutors of truth, the oppressors of eonscience and intelligence, feel the weight of his indomitable and avenging scorn (Odeurs de Paris, xvi). 
more spiritual qualities. Or rather it was unfavourable to the literary expression of these qualities: until his correspondence was published none but a few friends knew the real man.

Thus it was that this sincere Christian, this great and loving heart, spent his life denouncing and cursing. This turn of mind served him in one respect: he was no philosopher and little of a mystic, but he was a powerful moralist. If he seldom reminds us of Bossuet and Fénelon, he often is the worthy successor of Molière and of La Bruyère. His eighteen volumes of Mélanges and his two best-known books, The Free-Thinkers and The Odours of Paris, are mostly collections of moral satires.

The Odours of Paris (in opposition to Les Parfums de Rome) is Veuillot's masterpiece. The evil it denounces is not intellectual, as in the earlier Free-Thinkers (1848): it is the result of free-thought, the gross, cynical materialism of Parisian society in the closing years of the Empire. The pictures it offers are daring, the style crudely realistic. Our sympathy goes to Veuillot in his courageous war against undeniable evils; but here again he is blind to one side of the question. He assumes that immorality and free-thought go hand in liand; but among the corrupt politicians, journalists, actresses, financiers whom he denounces, not a few professed the most rigid orthodoxy. Victor Hugo, Quinet, had their small and even their ludicrous sides, no doubt, but they were in exile for conscience' sake. Science is and ever was bankrupt, Catholics assert. Granted; but all the prominent scientists of that time led admirable lives, unselfish and pure. Venillot was sincere and meant to be fair; but the rectitude of his moral judgment was warped by his intolerance. The book is a fine piece of literary work, and a precious social document: from the religions point of view, it is worse than unconvincing, it is repulsive. It ends fittingly with the famous paradox on the holiness of dirt.

The tone of constant bitterness and hatred which pervades all the works of Venillot soon becomes wearisome. No plea of " righteons indignation" could justify him for personal attacks on the private life or the bodily infirmities of men whose convictions differed from his. For the Revolutionary motto: "Liberty, Equality, Fraternity," he wished to substitute the 
Christian words: "Justice, Humility, Charity." But in the daily practice of these commendable virtues he failed utterly. "His delight was in cursing; he clothed himself with cursing as with a garment."

Yet he was at heart kind and loving. Even if we distrusted his long biography by his brother, * we should find in his correspondence the self-picture of a conscientious, sane, and affectionate man, more genuine, more manly, more lovable than most of his adversaries, rising without an effort to the heights of silent heroism in his days of trial and sorrow. In this, as in many other respects, he bore a curious resemblance to a man whom he considered as an Antichrist-P. J. Proudhon. Both were men of the people, and remained men of the people, even after they reached fame. Both were coarse, violent, paradoxical. Both hated the "enlightened" bourgeois, which, with the words "Progress, Liberty," always on their lips, thonght exclusively of their own welfare. Both were rigid moralists in word and deed, with a pure, modest, self-supporting home as their ideal. Both loved justice more than liberty, and were ready to serve Napoleon III. if he would be the champion of right. Both were full of rugged, popular eloquence, and fond of excessive, defiant affirmations. Both were hated and combated even by their own party. They stand as the most radical representatives of opposite causes - the Church and the Revolution. But on the tomb of his father, Veuillot thought: "This social edifice is built on iniquity : it shall be destroyed." He was at heart a Socialist. Prondhon devoted years of study to the Bible; his anti-theism is full of religious passion: a touch of the hand might have kept him to Christianity. Brothers and enemies, these two men were greater than their fate and better than their work.

\section{The Libcral Catholics.}

There are, or there were, liberal Catholics, but liberal Catholicism is as inconceivable as liberal arithmetic. A divinely appointed infallible Chureh must stand for authority and discipline. If it tolerates liberty, it ean be liberty only in non-

* Eugène Veuillot, a capital work in every respect. 


\section{FRENCH PROPHETS OF YESTERDAI}

essentisls. In essentials it must enforce unitr, else Catholicism

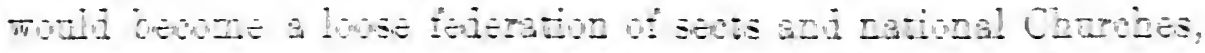

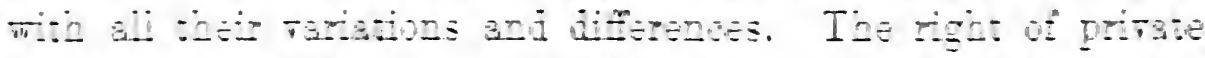

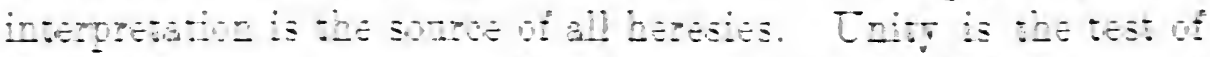

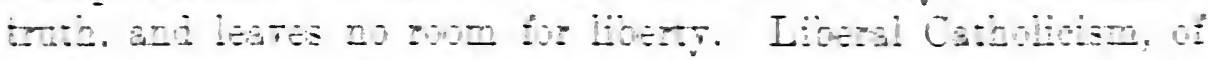

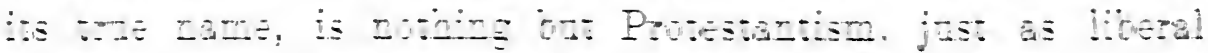

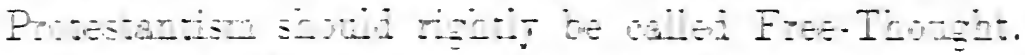

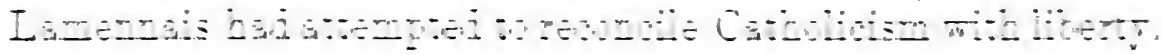
H:S

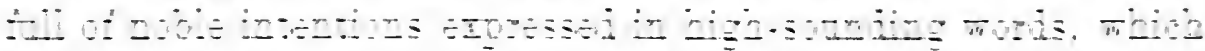
íz: $\therefore$ -

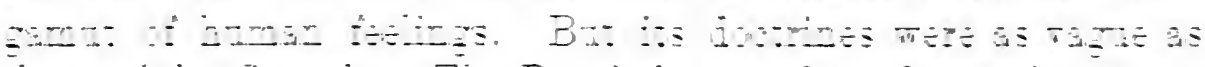

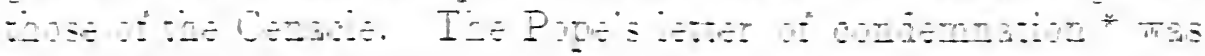

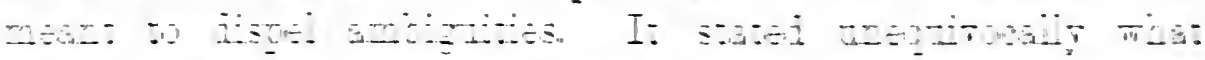
Ond

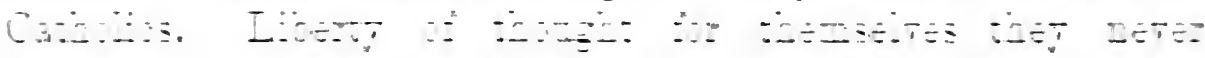

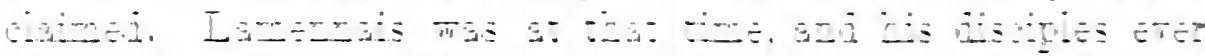

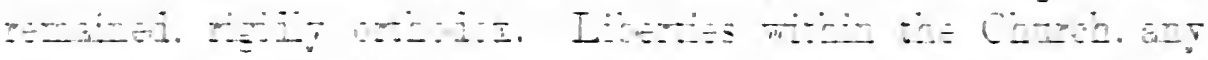

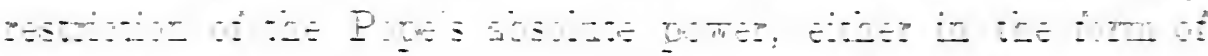

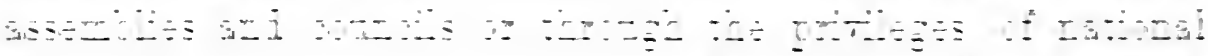
U a

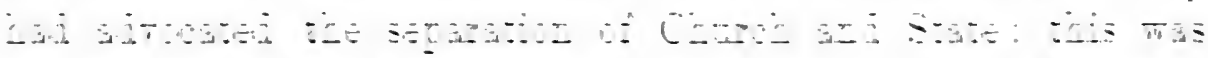

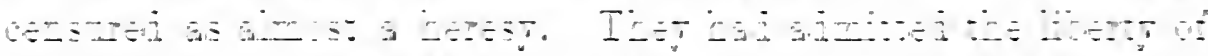

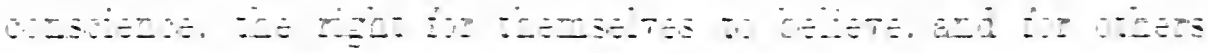

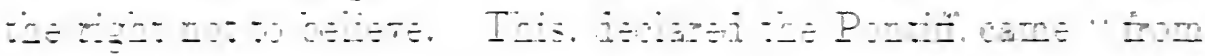

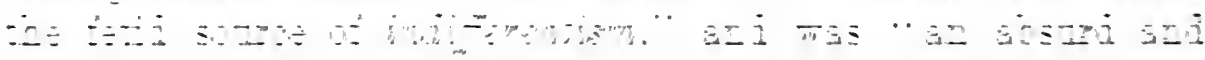

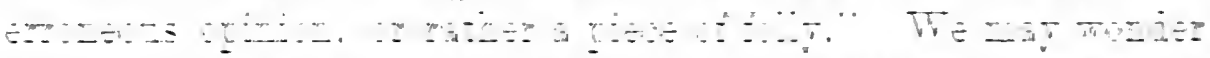

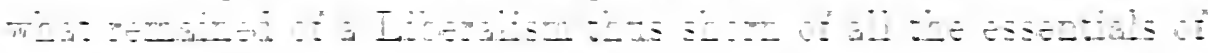

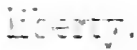

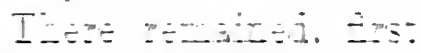

. 主

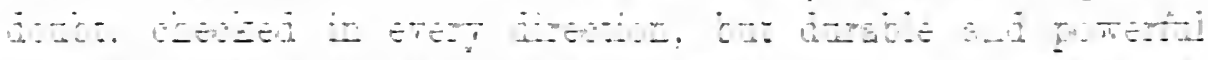

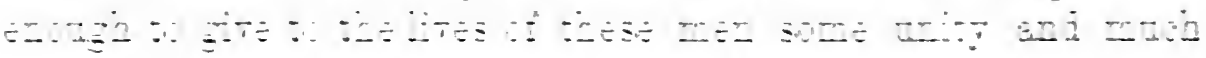

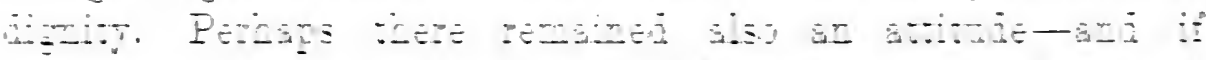
I

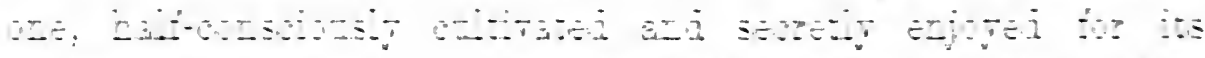

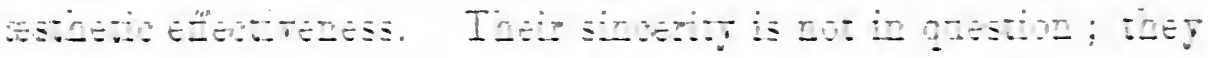

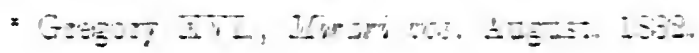


were not actors-but they were orators, passionately fond of public speaking and its exhilaration, and orators, after all, are actors who compose their own lines. Who can deny that there was some Romanticism à la Chateaubriand in Lacordaire's assumption of the white robe of a Dominican friar?

After the collapse of Romanticism in June, 1848, liberal Catholicism was a mere survival, an anomaly. The very term became looser, more ansbignons than ever. The liberal Catholic tendency was no longer fully represented by the liberal Catholic party. This party was a well-defined group, conscions of its unity, which was consecrated by the famous communion of La-Roche-en-Brény; * MIgr. Dupanloup, Montalembert, de Falloux, the de Broglies, were its leaders. By the side of this group, and not always in absolnte sympathy with it, stood Lacordaire, and in the following generation Hyacinthe Loyson, who were Christian orators more than party men, and democrats rather than parliamentarians. A third aspect of Liberalism can be studied in Mgr. Maret and Father Gratry, who, in the light of philosophy, attempted a genuine conciliation between the Church and the modern world.

The liberal Catholic party secured from the end of 1848 to the end of 1851 a degree of influence which it lost soon afterwards. But it was its persomnel rather than its principles that triumphed for a season. They were indeed able to achieve their great aim-to secure the liberty of edncation promised by the two revolutions of 1830 and 1848. But the spirit in which this conquest was made was very different from the youthful enthusiasm which pervaded The Future in 1830-31. The liberty of edncation was roted not as a progressive but as a reactionary measure. The bourgeois, scared and infuriated by the repcated

* Ieeting of La-Puche-en-Brény (Montalembert's country seat), October 12 , 1862. The menorial tablet-in Latin-reads as follows: "In this chapel Felix, Bishop of Orieans (Dupanloup), gave the bread of the Word and the bread of the Christian life to a little flock of friends, who, long accustomed to fight side by side for a free Chuach in a free country, rencwed their compact to devote in the same way the rest of their lives to God and to liberty. Present: Alfred, Comte de Falloux, Théophile Foisset, Aug. Cochin, Charles, Comte de MLntalembert. Present in the spirit : Albert, Prince de Broglie." This was denounced later by Veuillot as the mysteries of La-Roche-en-Brény, the sect according to Cavour. 
revolution of 1848 , were only too willing to strike an alliance with the Church. The result was the compromise known as the Falloux law-execrated by Radical Republicans to this day, denounced by Veuillot and the Theocrats, but which, after all, was fair and liberal enough to stand the test of sixty years. With some indulgence, this equivocal measure can be described as the last triumph of the liberals. Henceforth they show nothing but reactionary tendencies or impotence.

Under the Republic Montalembert assumed a prominent place in French politics : but it was as a strict Conservative. "Absolutism may be a great evil," he said, "but revolution is evil itself, the incarnation of all falsehood." It was he who uttered the wellknown words: "We need a Roman expedition within our own borders [i l'intérieur] against anarchy." He was one of the chief agents of Louis Napoleon's presidential election, and in the anxious days between the Coup d'Etat and the plebiscite, he strongly advised his fellow-Catholics to vote in favour of the dictator. Plainly his Liberalism was in abeyance.

But even before the proclamation of the Second Empire he turned round again and went back to his former friends in opposition. Why this new conversion? Was Napoleon III. no longer the Saviour of Society and the Soldier of the Church? Veuillot, more consistent, remained faithful to the Empire as long as the Empire remained repressive and clerical. But Montalembert's Liberalism, in politics as well as in religion, was of a curious type, of which Burke was the most complete representative, and which, in modern parlance, we would call Conservatism. He loved liberty-that is to say certain forms and certain traditions, and the predominance of a well-to-do educated class; equality and democracy he hated and feared. The Napoleonic regime, based on the will of the people (expressed directly through plebiscites) and almost Saint-Simonian in its spirit, struck him as dangerously democratic and socialistic. Then the forms without which liberty such as he conceived it could not exist-i.e., a parliamentary government-were rudely swept aside. The Legislative Body was to be a modest, practical assembly, whose voice, until 1860, did not reach the public. Montalembert had approved of the sanguinary repression of June, 1848, 
and condoned the regrettable acts of brutality of December 4, 1851: but for an orator, the suppression of the verbatim parliamentary report was the one unpardonable offence. From the political point of view, the period of the Second Empire was the slow and painful agony of the liberal Catholic party. And when it came to power for a moment in 1870-for Emile Ollivier was a friend of Montalembert-the great leader was dying: fortunately for him, for he was spared the spectacle of a new failure of his opinions, followed by the downfall, not of the regime alone, but of the country.

Ruined as a political factor, the liberal group found its position within the Church hardly more satisfactory. Montalembert and his friends remained the nominal leaders of the Catholics, and still enjoyed some social prestige, but their influence was restricted to a very small circle. They were supreme in certain salons of the aristocratic Faubourg SaintGermain, especially in that of Madame Swetchine, a Russian convert, a friend of Joseph de Maistre, the confidante and adviser of Lacordaire, a strong and clever lady whom SainteBeuve, with characteristic irreverence, nicknamed a "Mother of the Church." They captured and controlled the most famous of all salons-perhaps the last-the French Academy. They were generally supported by the great liberal Pressespecially by Le Journal des Débats, and they had their own Review, Le Correspondant-a Revue des Deux Mondes with a cassock, Barbey d'Aurevilly called it. Within these narrow limits they were great men. Outside, and even in Rome, Veuillot alone outweighed them all.

For the Pope was committed to absolutism-the only policy consistent with his claims. The liberal Catholies condemned absolutism, and yet remained Ultramontanes. No wonder if they were considered by most democrats and free-thinkers as hypocrites, and by the Holy See as unreliable servants. Veuillot, not they, had the right to speak in the name of the Pope-and they denounced him with a violence equal to his own, although expressed in more dignified language. Yet Veuillot did nothing but translate into strong, popular French what Pius IX., Gregory XVI., and the long line of their 


\section{predecessors, Gregory VII., Gregory IV., had affirmed in stately Latin.}

The position of the liberals was thus a paradoxical one. Officially the leaders of French Catholics and the obedient servants of the Pope, they were openly distrusted by their troops, and secretly at odds with their master. Montalembert, de Falloux, de Broglie, and even Dupanloup were trained politicians, and it may be said without irreverence that they used their skill to the ntmost for dodging the issue. Yet they could not avoid repeated conflicts-especially with such an aggressive and uncompromising foe as Veuillot-and, of course, repeated defeat. Three episodes will suffice to give an idea of this internecine war.

In August, 1863, Montalembert attended the Catholic convention at Malines (Mechlin), in Belgium. He delivered one of his best speeches (20-21 August): "The old regime is dead, and will not rise again," he proclaimed. "In the old order, we Catholies have nothing to regret, and in the new, nothing to fear. Let us disown any dream of theocracy. Cæsars and Demagogues alike desire this horrible confusion of the spiritual and the temporal, the ideal of all tyrannies.*... The Spanish inquisitor who said to the heretic: Truth or death! is as odious to me as the French terrorist who said to my grandfather: Liberty, equality, or death!" + These are fine and strong words; but at the same time, the Catholic party-liberals included-supported "that horrible confusion between the spiritual and the temporal " in Rome. The advocate of toleration recognised that the individual conscience must be independent of the State, but not of the Church, $\ddagger$ and he had admitted before, "unhesitatingly," that if one could suppress the liberty of error, it would be a duty so to do.\$ $\mathrm{He}$ was obliged to establish a distinction between the thesis and the hypothesis: from the Catholic point of view the liberty of thought is to be condemned, but, under present conditions, and as an expedient, it is legitimate. In spite of all precautions, contradictions, and

* L'Eglise libre dans l'Etat libre, Paris, Douniol, 1863, p. 102.

$\dagger$ Ibid., p. $135 . \quad \ddagger$ Ibid., p. 87.

$\S$ Les Intérêts Catholiques au XIXème siecle, 1852, p. 99. 
implied retractations, the speech was denounced by Le Monde; * the Pope repeated that to believe in the possibility of salvation outside the Church was a sin, and Cardinal Antonelli, the Roman Secretary of State, wrote to Montalembert a letter of blame. A new congress was held at Malines the following year : Montalembert found it advisable to take no active interest in it.

In 1864 came the Encyclical "Quanta Cura" and the Syllabus. The Absolutists were exultant. Le Monde quoted with approval the motto of the Pensamicnto Espanol: "All our faith is to stigmatise, as anti-Catholic, liberalism, progress, and modern civilisation." It was a crushing blow for the liberals. But Mgrr. Dupanloup rose to the occasion. With admirable ingenuity he explained away the dangerous document. The terrible last anathema, so direct, unequivocal, and inclusive, must have taxed Mgr. Dupanloup's subtlety to the utmost. Finally, it was satisfactorily twisted round like the rest. We should not say that the Pope ought to be reconciled and to compromise with progress, liberalism, and modern civilisation; of course not: for that would seem to imply that he is not in full sympathy with them already. The Court of Rome, with its strange mixture of intolerance and diplomacy, approved Dupanloup's interpretation as well as that of the Pensamiento Español. By this clever move, Liberalism saved its fice for a season. $\dagger$

The worst was still to come. In spite of his anti-Gallicanism, Montalembert had been driven to the conclusion that an absolute Papacy was incompatible with any form of Liberalism. When rumours began to spread of the prospect of a council he welcomed the idea. A council was a Parliament; perhaps it was time yet for the constitutional element in the Catholic organisation to be asserted and developed. But he very soon understood that the Council would be the death of Liberalism. Such a reign of terror prevailed in the Chureh that he, the great leader, could not express freely his opinions. His friends and brothers-in-arms, Dupanloup and de Falloux, refused to insert

* Veuillot's Univer's under a new name and without Veuillot, after its suppression by the Imperial Government.

† La Convention du 15 Septembre et l'Encyclique du 8 Décembre (January 13, 1865). 
his article in his own paper Le Correspondant. "Who could have foreseen," he wrote to Lallement, “. . . the permanent triumph of these lay theologians of absolutism [Veuillot], who had first of all trampled under foot all our liberties, all our principles, all our ideas of former times to serve Napoleon III., and then immolate justice and truth, reason and history, as a holocaust to their idol of the Vatican?" * Strong words again! But, illogical to the last, Montalembert blamed his friend, Hyacinthe Loyson, whose secession was already inevitable. He died a week after this letter was published. The Pope received at the same time his last printed words and the news of his death. "This man had a great enemy-pride," said the Pontiff. + In answer to a denunciation from a number of French bishops, Pius IX. sent a letter of commendation to Louis Veuillot; four months after Montalembert's death, Mgr. Dupanlonp left Rome in despair, on the eve of the proclamation of Papal infallibility. Liberal Catholicism was finally conquered.

\section{Philosophers: Mgr. Maret and Father Gratry.}

Montalembert and his group represent aristocratic Liberalism, refined and narrow, more political than religious, and, through its fear of democracy, led to inconsistencies and contradictions. Lacordaire, whose public career was practically over at the time we are studying, was more open-hearted, freer-minded, more popular in spirit, and not without a touch of romantic daring; but his doctrine lacked precision; he represented a temperament, a sentimental tendency, rather than a school of thought. A third aspect of Liberalism remains to be studied: the attempted reconciliation between the Church and modern thought, between faith and science, in a synthesis of their highest elements. Such efforts are innumerable in Protestant countries: within French Catholicism they are extremely rare. The Church does not favour reconciliation, but insists on unconditional surrender. Even the most liberal Pope of

* Gazctte de France, March 7, 1870; Lecanuet, Montalembert, vol. iii., p. 468.

+ Montalembert is not yet forgiven; his centennial was not celebrated in France, so bitter is still the enmity he roused among the Absolutists. 
recent times, Leo XIII., disapproved of modern philosophy, and wanted to restore St. Thomas's Summa to its full mediæval authority. But, fraught with dangor as it was, the attempt was made, under the Second Empire, by two sincere and courageous priests, Mgr. Maret and Father Gratry.

Maret hoped to reconcile tradition and reason through a revival of apologetic sciences, exegesis, sacred criticism, historical criticism, the philosophy of dogmas, in a liberal spirit. In other words, he wished to find in the immense arsenal of theology theories that would suit his purpose. At first, such a method seems akin to that of the three brothers in the T'ale of a 'Tub, who discovered everything they wanted in their father's will, or to the clever piece of theological jugglery by which Mgr. Dupanloup transformed the Syllabus into a liberal document. The French are as a rule only too fond of straight, logical thinking, an admirable quality which they carry to the limit of absurdity, and not seldom beyond. If they are convinced of certain truths for plain, scientific reasons, they will not seek out an ambignous confirmation of the same truths in ancient texts tortured out of their original meaning. If the earth does turn, it matters little whether theology can adjust itself to the fact or no. Whilst the English construe an old Act so as to fit new conditions, and will probably apply an Elizabethan statute on falconry to the regulation of aeroplanes, the French prefer to pass an entirely new law on a new principle.

Yet the attempt, un-French as it was and doomed to failure, was noteworthy, at least from the practical point of view. Intellectually, it is easy to do withont the doctrine of the Roman Church; but there is in Catholic tradition and discipline an inmense capital-poetic, moral, spiritual-which we can ill afford to reject. Mgrr. Naret felt that the estrangement between the Church and modem culture would deprive good men, on either side, of advantages which by right were their's. Even if he did display excessire ingenuity in the service of such a canse, he might easily be partoned.

His theory is by no means incompatible with a certain conception of orthodoxy and tradition, and curionsly enough, with a conception popularised by the great absolutist and infallibilist 
de Maistre, long before Newman stamped it as his own : the doctrine of continuous revelation through the Church, and consequently of the evolution of dogma. This doctrine is of its very essence Catholic; not only does it make the Church instead of the individual the final authority in the interpretation of the Bible, but it exalts the Church above the Bible itself, for whence does the Bible derive its canonical sanction, if not from the Church? At the same time, this strictly historical conception allows every hope of progress. It is a conservative but a living faith, in harmony with England's conception of liberty, "slowly broadening down from precedent to precedent," and with the new theory of evolution, which, under the Second Empire, was inst taking such a hold of scientific minds.

The obstacle, Mgr. Maret thought, was not in the essence of Catholicism, but in the present form of its government. The Pope was "exposed to the ordinary and inevitable temptations of absolute power." But the Church need not for ever remain what it had slowly become, an absolute monarchy. It contains the elements of an aristocracy, and even of a democracy. The salvation of Catholicism lay in a liberal constitutional reform through a general council (Memoir to the Bishops). Mgr. Maret expanded these ideas in a book, Du Concile Général et de la Paix Religieuse, which was printed at the expense of the Emperor. Rumours went abroad that the author was preparing a schism on national-liberal lines, with the support of Napoleon III.* The impossibility of such a scheme is manifest. Maret had not the temperament of a Luther; Napoleon III., whose religious views were somewhat hazy, had no thought of embarking, at such a critical time for France and his dynasty, on so formidable an adventure as a new reformation. The printing of the work was delayed two years by intrigues and secret hostilities. When it appeared at last in 1869, the triumph of the infallibilist party in the future council was a foregone conclusion. Denounced by Mgr. Pie, the book was immediately placed under a ban, and after the Council the author himself assented to its suppression.

* Good observers at that time-Renan was one of them-seemed to believe in the possibility of such a schism. 
Mgr. Maret had a definite policy of Liberalism, going to the root of the difficulty, the government of the Church itself. The issue was tried and decided against him. He could hardly get a hearing in the Council; he was jeered at and insulted by the Infallibilists.* $\mathrm{He}$ was fighting against an irresistible movement and several centuries of Church traditions. His attempt, so plausible in theory, did not even attract much attention at the time. In onr days it is deeply forgotten. The Modernists themselves, who tried to carry out some of his theories, never mentioned his name: his failure was too sure an omen of their own.

Father Gratry is better remembered. During the Second Empire he was one of the most prominent figures in French Catholicism. Brilliant, ardent, versatile, imaginative and systematic at the same time, easily swayed by one idea and not long by the same, he threw himself headlong into the great controversies of his time. With Mgr. Dupanloup, he waged war against sceptical and anti-Christian philosophers (Vacherot and Renan). With Hyacinthe Loyson, and in the best spirit of Lacordaire, he was interested in modern problens, the needs of the people, the cry of oppressed nationalities, international brotherhood, and he wanted the Church to use her powerful influence in favour of all noble causes. Like Maret, but with less prudence, more imagination, and more charm, he attempter to reconcile science and faith in a synthetic philosophy.

Even when he attacked philosophers, it was in the name of philosophy-as sophists rather than as infidels. For Gratry believed in Reason, and defended its claims right and left, against the fideists like Bautain, who held that faith transcended human understanding, and against the French Hegelians, who, as he understood them, ruined all certitude with their endless chain of contradictions, their universal relativism, their conception of God as merely an ideal. The Catholic philosopher was in this purely orthodox-for fideism is a heretical tendency, as

* In MIgr. Fèvre's Histoire critique du Catholicisme libéral en France (1897) the violence of the attacks against Mrgr. Maret is almost incredible ("a life full of crimes"), yet Haret escaped formal censure and died an archbishop: a masterpice of perseverance and diplomacy! 
M. Brunetière discovered a little too late; at the same time, he seemed on this point a more direct disciple of the Encyclopædists than our modern free-thinkers. Reason defended in the name of the Church, by a priest, against unbelievers: Voltaire would have enjoyed that paradox.

But Reason, as Gratry understood it, was more than the reasoning faculty. The old form of reasoning, syllogism, is barren, and the logic based thereon must remain critical rather than constructive. Gratry was intent on realising a synthesis of all forces in the human mind-intellectual, sentimental, spiritual. For, whether organic, intellectual, moral, or spiritual, life is one. A machine could reason syllogistically; for a human being, pride and sensuality are obstacles, love and virtue are avenues, to the discovery of truth.

Therefore, instead of the Cartesian method of pure deduction from intellectual axioms, Gratry adopted the Baconian method of induction or transcendence. Through this dialecties, he hoped to rise from sensible things to intelligible things, thence to the necessary truths which are "the adumbrations of God," thence to God himself. In the application, he used the infinitesimal method of Leibnitz and Newton, without perhaps stating clearly enough whether he meant it as a demonstration or as an analogy. This gave rise to the legend of his haring proved the existence of God mathematically and given "the formula of God."

But this dialectical progress necessitates a corresponding spiritual progress. We must develop what Pascal called the heart, Socrates the prophetic soul, and himself the sense of God; superior to abstract reason, which gives us only ideas; different from faith, which gives us revealed truth. If we would but conquer pride and sensuality through sacrifice and love, then the sense of the divine would derelop freely, and we would realise the absolute congruency between the revealed Word and our aspirations and needs: "Induction, sacrifice, and grace lead us to the throne of God."

This philosophy, like Cousin's, was an eclecticism. Gratry did not believe in systematic doubt as a necessary first step; we should not isolate ourselves from the past experience of the race, 
we should accept all the great results acquired by human reason. Thus in his treatise on the Knowledge of God, he passes in review the doctrines of Plato, Aristotle, St. Augustine, St. Thomas, Pascal, Malebranche, Fénelon, Petau, Thomassin, Bossuet, Leibnitz. But his eclecticism is very personal and innocently unscrupulous; for he would "gently solicit his authorities,"* and even hunt up favourable quotations in tables and indices. With such a method one could array the Church Fathers against Christianity; but it is brilliant and convenient, and is still a great favourite with ortnodox apologists.

The great objection to Gratry's eclecticism-and perhaps to all forms of eclecticism-is that it remains syncretic rather than synthetic: science, imagination, conscience, mysticism, historical revelation, are juxtaposed rather than harmonised. We have already referred to the somewhat unexpected introduction of mathematies into theology; crities had no difficulty in showing that there was no possible assimilation between the mathematical infinite, which is only the indefinite, and the metaphysical infinite, which is absolute. The admirable chapters in De la Connaissance de l'Ame on the place of immortal life $t$ are a grand astronomical poem, more impressive than Reynaud's Terre et Ciel, by which they were probably inspired. But they are neither science nor philosophy, and still less theology: they are sheer Romanticism. The affirmation that pride and sensuality are obstacles to the clear conception of truth is legitimate; but the assumption that truth and the Christian revelation are coextensive is philosophically unwarranted. At the bottom, this is the same dangerous and intolerant doctrine as Veuillot's ; unbelief is not an opinion, not even simply a misfortune, it is a sin ; Renan, Havet, Littré, even Vacherot, are not mistaken, they are perverse. A Catholic philosopher does not discuss, he rebukes. Finally, the introduction of the miraculous and of mysticism-which played no small part in Gratry's life-made the logical and scientific passages futile. A single breath from beyond dispels his elaborate castle of smoke.

* The expression is Renan's-a confession as to his own mothod.

t This immortal world will be the inside of a sphere, at the place towards which all constellations are now gravitating. 
In short, Gratry's philosophy held out magnificent promises which it could not keep.

The true, the best Gratry was not in his harsh and biased criticism of modern "sophists," as he chose to call them, nor in his chaotic metaphysics, but in warm-hearted, poetical passages throughout the heavy treatises, in such a little book of spiritual directions as Les Sources, or in the second volume of De la Connaissance de l'Ame, devoted to immortality. Simple as a child, impulsive, loving, Gratry was meant to be a spiritual force in a non-intellectual way. He was, like Lacordaire and Loyson, a romantic humanitarian in the best sense of the term-a believer in peace, fraternity, democracy, progress, a man whose true place would have been by the side of Lamennais, Hugo, Michelet, George Sand, Pierre Leroux. But for that very reason he was, again like Lacordaire and Loyson, isolated in the Church and distrusted. The Council of 1870 struck him as it struck all the other liberals. He had, more courageously although less consistently than the rest, opposed the claims of the Papacy. When the Infallibilists triumphed, he did not go to the extreme of seceding, like Döllinger or Loyson; but for two year's he could not make up his mind to give his adhesion to the new dogma, and for two years, in Belgium as well as in France, he was pitilessly pursued by the victors, mintil in doubt and despair, and on the point of death, he submitted.

Perhaps his last declaration gives us the truest picture of his generous soul: "My friends, you do not doubt the position I have taken before God, before truth, before the charity of Jesus Christ.

"You who wish to crush the human mind under your pharisaical hypocrisy, it is not for you I have laboured.

"You who wish for the destruction of the unity of the universal flock, it is not for you I have laboured.

"You who want all the truth in all the charity of Jesus Christ, it is for you, my brothers, Christians visible and invisible, Christians hidden under other names; for you, men of conscience and reason, men of kind hearts and goodwill, you who wish the prompt gathering of all upon earth, and the Kingdom of our Father in Heaven, it is for you I have laboured. 
"I hail you and bless you; I clasp you in my arms, and this kiss of peace which I give you, and which several of you will receive in their generous hearts, is to-day for me a profound joy."

\section{Ernest Hello.}

Ernest Hello stands alone. He is perhaps the best example in modern French literature of the "illustrions unknown." All the safe and authoritative critics seem never to have heard of him, and his name is mentioned with bated breath by the chosen few who love to worship at a mysterious shrine. He is not forgotten or despised after a season of popularity: he nerer secured recognition. The general public was not attracted by books outwardly similar to the insipid literature of piety published by Mame, Domniol, Poussielgue, or Vaton. Among Catholics, Tenillot knew him and admired him, and Veuillot was then a power in the Church; but he made no effort to bring out an author who, incapable of self-advertisement, greatly needed his support. Why? Barbey d'Aurerilly and Léon Bloy, whom he treated with the same indifference, hint that jealonsy may have been the reason. We prefer to believe that Veuillot, a busy journalist and a determined fighter, had no use either for independent artists or for a dreamy mystic. As for the men who are the main strength of Catholicism, and who, being mystics themselves, could best understand and enjoy Hello, they are, as a rule, totally indifferent to secular literature; to Léon Bloy, who praised before him Hello's flashes of genins, a monk, the head of an important Order, replied: "All has been said by St. Angustine and St. Thomas-we have no need of M. Hello's, or anybody's, flashes." An admirably orthodox opinion, to be sure; it was the one which prompted the destruction of the Alexandrian Library. Thus poor Hello remained withont a public. The tragedy of his fate was that, weak and self-diffident, he craved for, he imperionsly needed, the stimulation and exhilaration of fame, which was ever denied him: "Withont glory, one can complete only the skeleton of one's work."

But it was not only the lack of recognition that paralysed 
Hello's development. He was, from infancy, sickly, timid, morbid, and he remained during the fifty-seven years of his life a spoilt child and an invalid. His wife, active, capable, devoted, spared him all the cares and hurts of material existence-but her cruel kindness made him weaker, more abjectly dependent, so that his friends would at times consider his guardian angel as his curse. Hello is the type of the poet defined by Alfred de Vigny and Lombroso-abnormal and ailing. Stooping, haggard, dragging his eternal umbrella, he was indeed Baudelaire's "Goëland":-

"Ses ailes de géant l'empêchent de marcher."

Of his genius, himself and his immediate circle of friends never had any doubt. His soul was luminous-absolutely pure and sincere. He had an innate horror for anything low, and when he had said of a thing, "It is low," by sheer force of conviction he imposed his verdict on his friends. $\mathrm{He}$ is among the few modern writers who give their readers the shudder of the infinite. He was a seer, and one at least of his prophecies was fulfilled with terrible accuracy. In 1867 he said: "The Tuileries are not yet ablaze! Why do the Barbarians delay so long?" Three years later they came from without and from within, and the old palace of the French kings was a heap of smouldering ruins.

Hello was a Celt, a Breton, like all the great leaders of religious thought in nineteenth-century France, Chateaubriand, Lamennais, Renan. But he was in spirit a Celt of the Celts, unromanised, without Chateaubriand's classical culture and Renan's Gascon scepticism and humour. He was a dreamer, a mystic; he despised plastic beauty, order, logic, wit, common sense-all that was low. His sympathy went exclusively to symbolic art, to hieratic Egypt, to the mysterious East. His criticism, guided by such preferences is, of course, unconvincing to a ludicrous degree. Greece and Rome lack sublimity; Eschylus and Homer are not Greeks, but Orientals, and in Plato there co-existed two men: a true Greek, a pagan, rhetorical, sophistic, heavy, affected-and a Chaldee, simple, 
grand, the one who created the myth of the cave. Germany he loves, because there lingers on her an Eastern afterglow. The eighteenth century, which wanted to eliminate mystery, reached the lowest depths of degradation. Romanticism is defined as godless mysticism-a yearning for the infinite without Him who is the infinite. As criticism, Hello's articles and his book Le Siècle are on the same plane as Victor Hugo's William Shakespeare, but as self-revelation they are precious.

With Father Gratry, whom he recognises as his master, Hello opposed philosophy, which builds up, to sophistry, which can only destroy; synthesis, which is life, to analysis; systematic faith to systematic doubt. He had no system of his own; he was a Catholic and accepted the philosophy of St. Thomas. But as a Christian apologist he had splendid passages and deserved to be called, without irony, "the Pascal of Keroman." Critical philosophy leads to pyrrhonism, to the negation of religion, society, science, and art-to universal anarchy. The only alternative is Christianity. The evidence of Catholic Christianity is its unity. It is a miracle in itself, impossible according to Nature; therefore it must be supernatural. "Thinking on these things, on which my eternal future depends, in the eye of God whom I cannot deceive, engaged in the chain of beings, called upon to make a choice, considering that I was created for life, not for death, for truth, not for error, for love, not for hatred; considering that, unable to reach by my own efforts the goal of my desire, I need a hand to lead me thither, I surrender myself to the Church eternal." *

This is an abdication, not a demonstration. The proof derived from the unity and "unnaturalness" of Christianity can hardly be taken seriously. Hello, who had at least dabbled in the history of early Christian sects, $\dagger$ must have known how precarious, artificial, and superficial such unity had always been. But the interest of Hello's philosophy is not in its systematic side; it lies entirely in its symbolic and mystic notes, almost

* Philosophie et Atheisme, 300.

$\dagger \mathrm{Ho}$ was fond of showing that modern philosophical errors had boen anticipated by the heretics of the early Church. 
unique in his time and country: "The voice of creation," he wrote, "is deep and clear, gentle and mysterious. It seems to defend a secret, and gravely to invite men to respect that which they do not know. . . . It leads us beyond itself. . . But deeper still, symbolism, flashing on creation like lightning through the night, throws a new and more mysterious light on universal order, which it enlarges without deforming. Uniting the visible with the invisible world, symbolism half discloses a strange secret: the relation of relations, the harmony of harmonies; and through this new complication, the simplicity of Order appears more gigantic." *

Hello translated and edited two classics of mysticism, The Book of the Visions and Instructions of the Blessed Angela de Foligno (1868) and The Selected Works of Rusbrock [Ruysbroek] the Admirable (1869). He himself "wrestled with the unutterable," as he said of Angela, and the closing lines of his principal work attempt to transcend the limits of human speech: "At last we shall see face to face the Holy Ghost, the union of Father and Son, the repose of their love, Him who allows Himself to be symbolised by oil, and who ordered to anoint the sick with oil while praying for their recovery, the peace and joy of the Lord, which passeth all understanding, harmony, immense, infinite, eternal, absolute, absolutely ineffable, absolutely adorable, harmony, in a word, harmony, harmony." $\dagger$

Here the very failure of words suggests realms of thoughts and feelings beyond. But the very essence of mysticism is incommunicable, and much that the mystic writes must seem to the uninitiated sheer nonsense. Hello was conscious of this limitation and expressed it admirably: "Their words [of the mystics] are a journey which they take, moved by charity, among the other men. But silence is their home. The splendour of their language is but the condescension of their love: the sacred darkness in which they spread their eagle's wings is their ocean, their prey, and their glory." $\ddagger$

Unfortunately, our mystic was a journalist and a controversialist, who wrote for L'Univers, Le Monde, Le Constitutionnel,

* L'Homme. $\quad+$ Philosophie et Atheisme, 332. $\quad \ddagger$ Rusbrock, xx. 
Le Moniteur, Le Gaulois, and for Brussels and New Orleans papers. He had to leave every day his "sacred darkness," "Silence, his home," and the intervals between flashes of inspiration were filled anyhow. Sometimes he would use the most insipid edifying style, and Huysmans wrote later with cruel truth that "Hello prophesied from a rock manufactured for the Bondieuseries of Saint-Sulpice's." More frequently he would imitate the pseudo-sublimity, the apocalyptic utterances of Victor Hugo at his worst, the divagations which called on the great poet Veuillot's sarcasm : "Jocrisse à Pathmos." All the tricks found in Hugo's Shakespeare, for instance, are already in Hello's M. Renan, l'Athéisme et l'Allemagne; the alternations of long periodic sentences with paragraphs of a few words, the childish and pedantic fondness for etymological lore, the profound sayings which are but solemn puns,* the far-fetched, extravagant symbols. $t$ Hello, who defined Romanticism as mysticism minus God, was himself emphatically a Romanticist. He had started a paper-The Crusader-which was to renew the attempt of Lamennais's The Future, but steering clear of heresy. He liked Lacordaire's spirit and style, if not his philosophy; and he was fond of reading alond either his own prose or Victor Hugo's, which he sincerely admired. But as a Romanticist he had not the variety of effects and the supreme mastery of style that Victor Hugo preserved even in his worst passages; he had not Lamennais's passionate intensity nor even Lacordaire's more commonplace but effective rhetoric. His style, says M. Aguettant, gives the impression of an anthology from some great writer with the undistinguished prose of his editor to fill the gaps. On a higher plane he is almost as tantalising and as discouraging as Strada.

Hello's influence on French Catholicism was negligible. On literature his action is traceable, not so much on Villiers de l'Isle-Adam, his contemporary and a Breton like himself, as on

* "There is Silence in Tacitus."

f "On this wood was nailed the Word made flesh. The body was raised vertically: line of life. The arms were stretched horizontally: line of death. Thus was symbolised the sacrifice which contains life and death reconciled" (Philosophie et Athisme, p. 328. Cf. the extraordinary symbols used by Victor Hugo in La rin (le Satan). 
Léon Bloy, although that powerful, eccentric writer is as wilfully brutal as Hello was noble. Huysmans and Maeterlinck, especially the latter, owe much of their fondness for literary inysticism and a few of their tricks of style to the half-forgotten Pascal of Keroman. That he should ever become popular is improbable; the great bulk of his work does not deserve it and the golden passages cannot appeal to the crowd. A discreet, almost secret, but pure and indestructible fame, like that of Alfred de Vigny, will not be his either, for there is a morbid element in his genius and he is seldom great except when words fail him. He will remain, a weakling tonched with genius, in the chiaroscuro of esoteric glory.

\section{Conclusion.}

We have attempted to show to what materialising influences French Catholicism was submitted under the Second Empireon the one hand, its alliance with anti-socialistic reaction, on the other, the question of the Temporal Power of the Pope; how the development of Ultramontane ideas, long favoured by the liberals themselves, had made the Pope's authority more absulute and less disputed than for centuries before; how, in Pius IX., the rigid believer and the frightened temporal sovereign agreed in a doctrine and a policy of opposition to modern progress. Several attempts were made to resist these retrograde influences: all failed.

Montalembert and the political Liberal group tried to reconcile the strictest orthodoxy and the most rigorous Church discipline with the principles of constitutional liberty in the State. Opposed by the absolutists, they were openly censured by Rome. Laccrdaire, Gratry, Hyacinthe Loyson, orthodox and respectful sons of the Church, took active interest in all modern problems, and their generous sympatiny went to freedom, democracy, peace. They were all distrusted: Lacordaire died obedient, but despairing; Gratry was blamed and driven to the verge of rebellion; Loyson had to break away from the Roman Church. Maret, Gratry, Hello, attempted to bridge the chasm between the Church and contemporary thought. Maret was treated as an enemy; 
Gratry was applauded when he criticised, ignored when he sought to build up; Hello remained unknown.

Whilst the most intelligent members of the old aristocracy, conservative and cultured men like Montalembert and de Broglie, were held in suspicion, whilst warm-hearted orators and wellmeaning philosophers were neglected or censured, a journalist, powerful and admirably sincere, but narrow, violent, and vulgar, became the dictator of the French Church, the judge of Academicians, monks, and bishops.

Hence an undeniable lowering in the character of French Catholicism, a recrudescence of materialistic superstitions, the uncritical acceptance of doubtful miracles, * a tone of bitter arrogance in controversy, charity sneered at, and faith reduced to blind obedience.

It is not strange, therefore, that gradually all the masters of French thought should have passed over to anti-clericalism. The movement began with the condemnation of Lamennais (1832); it was partly checked by the success of Lacordaire's lectures (1835) ; it received a new impetns from the excessive bitterness of Montalembert's altack on State education (1842-44) ; lulled again in the early days of the Second Republic, it became irresistible after 1849. Victor Hugo, Quinet, Michelet, SainteBeuve, George Sand, Mérimée, Emile Augier, Leconte de Lisle were violently "anti-clerical"; and if the now generation, represented by Taine and Renan, were more moderate in the expression of their hostility, it was out of self-confidence rather than hesitation: they thought Science was already supreme, and could afford to be contemptuously fair to her fallen rival.

We may regret such a development. But the attitude of the Church was consistent throughout; no other was compatible with her principles, claims, and conditions. The liberals of all descriptions within the Church, the eclecticists without, some with admirable earnestness, some with excessive cleverness and diplomacy, attempted many compromises : all were spurned. Rome would admit no alternative but theocracy and free-thought : France did not choose theocracy.

* La Salette (1816), Lourdes (1858). 


\title{
CHAPTER II
}

\author{
PROTESTANTISM
}

\section{The Struggle between Orthodoxy and Liberalism.}

The place of Protestantism in the religious life of nineteenthcentury France is singularly hard to define. We do not accept the extreme opinion of the Traditionalists, who maintain that the Protestants, in France, are an alien element, more in sympathy with foreign countries than with the land of their birth. French Protestantism has its roots deep in the national soil. Was not Gerson one of the forerunners of the Reformation? Did not Lefebvre d'Etaples anticipate Luther? Is not Calvin French through and through, in his love of rigid system as in his mastery of the vernacular? Indeed, Protestantism is more truly national than present-day Ultramontanism. A "Nationalist" party submitting, even in political matters, to the dictates of a foreign potentate; a "Traditionalist" and monarchical school of thought disclaiming the constant tradition of our old kings and clergy, disowning Louis XIV. and Bossuet: such a school and such a party have no authority to excommunicate the descendants of the Huguenots.

Yet the French Protestants are different. They feel it themselves. Catholics and Voltairians, Romanticists and Positivists may fight bitterly: they cannot ignore each other. While they oppose, they complete one another: they are part of the great national system. The Protestants stand by themselves. They have their own traditions, their own sympathies. They are faithful to traditions which the rest of the country has forgotten. They are not, strictly speaking, foreigners: they are a small French nation within the great nation.

After the Edict of Nantes, which registered the failure of 
Protestantism in France as a national movement, the Huguenots seemed on the point of securing a semi-independent political existence-with their privileges and their cities of refuge. Richelieu ruthlessly shattered their hope. The policy of Louis XIV., culminating in the Revocation, made it impossible for them to merge in the general body of French citizens. The concessions of Louis XVI., the complete equality proclaimed by the Revolution, came too late. The Protestant nation was formed, moulded by a hundred and fifty years of persecution : too strong to be absorbed, too weak to play a prominent part, an obstinate survival rather than a growing force.

Persecution, at least, was a stern monitor; it saved the great moral traditions of the sect. But when quieter times came at last, it was to be feared that Protestantism, reduced to the position of a small historical body, not fully in sympathy with the general life of the nation, would grow narrow and slack, and morally degenerate. Such was indeed the case; there had been admirable characters among the "Ministers of the Desert" in the eighteenth century : their successors were too often indifferent and commonplace. After the official recognition of the Reformed Church (1802), the Dean of the newly-established Divinity School at Montauban was obliged to say: "Our soul, O Lord! is afflicted unto death, because of the languid and wasted condition of Thy Church." *

The great Revival of the early nineteenth century was of foreign origin. It did not begin until the treaties of Vienna had re-opened France to English influences. Cook and other disciples of Wesley evangelised the South in 1818. The movement assumed great proportions, but it remained decidedly English in its origin and character. On the other hand, the revival of Biblical studies, marked by the creation of the Review de Strasbourg in 1850, was a belated result of German influence and prospered on semi-German territory.

French Protestantism, reduced to its own forces, would have gone into a decline; cosmopolitan sympathies saved it. Henceforth, the Protestants will consider Geneva, Edinburgh, The Hague, Berlin, as their religious capitals. Some of their

* Coignet, Le Protestantisme français au XIXeme siecle, p. 36. 
best men were of mixed blood. Scherer was of Swiss, English, and Dutch origins; the Monods have passed from Switzerland to Denmark, and have connections in all Protestant lands. Athanase Coquerel was born at Leyden, of Huguenot and Covenanter parentage. All spent years of study abroad. The Protestant nation is thus more cosmopolitan than the rest of the French, freer from prejudices, freer from objectionable national characteristics. It is, on the whole, probably superior to the main body-but it is different.

This "character apart" explains why so many great Protestant names leave the French public at large indifferent. The Monods, the Coquerels, the Révilles, the Gasparins, the Stapfers, the Sabatiers, Reuss, Colani, Secretan,* Laboulaye, Bungener,* Passy, Pelletan-Protestantism may well be proud of such a list, by no means exhaustive, of preachers and historians, scholars and philosophers, philanthropists and politicians. Yet how many of these brilliant men were genuinely popular? How many secured a permanent place in French literature? Scherer conquered authority rather than fame, but this was not until he had abandoned Protestantism and devoted himself to literary criticism and political journalism. Guizot, on the contrary, took his rank as a historian and a political orator long before he became an apologist. His Méditations sur la Religion Chrétienne, as Vitet regretfully remarks, made no visible impression on the French public. The author was illustrious, the book was heralded by the influential Revue des Deux Mondes, religious passions were at their height, Renan's Life of Jesus was the "best seller" of the season: yet the only result of Guizot's efforts was "the conspiracy of silence." Quinet, often cited as one of the most famous names in nineteenth-century Protestant literature-Quinet was not a Protestant.

A literature is the flower of a civilisation, and French civilisation is not Protestant. Rostand's symbol holds true; Chantecler cannot crow unless his talons be firmly planted in the native earth, unless its sap, as it were, rise and flow through his body. 
But if Protestantism is of little importance in the general development of the nation, it becomes extremely interesting when studied from within. For the very reason that it forms a semi-independent body within the main body, it is a perfect microcosm, with all the varied aspirations, the conflicting passions, the party feuds of the greater communities. It does not form a solid army, opposed to the armies of Catholicism and Free-thonght: it has its own catholicism within itself, as well as its own free-thought. It does not take any well-defined part in the general conflict: it offers a separate but curiously parallel reproduction of the whole conflict on a smaller scale.

In the very essence of Protestantism we find this eternal opposition between authority and liberty, between tradition and reason. This inner contradiction has never been solved: it is doubtful whether it ever will be. If the principle of freo personal interpretation is followed to its logical end, the Church may retain spiritual influence, she will lose all spiritual authority. She may offer her services as a teacher and a guide; she may claim to express the opinion of the wisest, or of the majority; by this title she may advise, encourage, rebuke: she can no longer command. No interpretation of Scripture, however obvious, time-honoured, and universally accepted, can be enforced; no interpretation, however fanciful and revolutionary, can be condemned: the very notion of orthodoxy disappears, or rather orthodoxy is reduced to one dogma, the Divine inspiration of the Bible. The individual conscience recognises no master but the Word of God.

But, if the authority of the Church be ruined, how is that of the Bible to stand? The Bible is a collection of books: how was this collection made? Why are certain books included which do not claim to be Divinely inspired? Why are others rejected as apocryphal? By whom, when, how, was the text first written? How was it transmitted to us? All these questions arise invincibly. Curiosity is inseparable from reneration. If the Bible is all-important to us, we must know everything about it. Biblical criticism is the sign, not of scoffing incredulity, but of reverence and faith. If we find that fallible men selected these books, that fallible men translated them, 
transcribed them, originally wrote them, centuries ago, in an imperfect language, for an uncivilised people, how can we believe that every jot and tittle of the book is Divine? Are we not led to the conclusion: "The Bible is not the Word of God, but it contains the Word of God"?

Thus the last great dogma of Protestantism loses its absolute character. If the Scriptures are not literally inspired, how are we going to distinguish between what is the Word of God in them and what is purely human? The only test will be the harmony between the revelation in the Book and the revelation within our own hearts. We shall believe only what we feel to be true. The individual conscience, therefore, has not only the right of free interpretation, but the right of free criticism. Does not this mean that the Bible is no longer the final authority? Emancipated from tradition as embodied in a Church, the soul will also be emancipated from tradition as embodied in a book, and in the words of F. Buisson, "l'idole de papier doit suivre l'idole de chair."

From such conclusions, blasphemous in their eyes, many Protestants shrank with horror. We camnot tax them with being illogical. A great living religion is not an abstract reasoning; the so-called principle of Protestantism, free interpretation, is not the whole, nor even the centre of Protestantism. The authority of the Bible is the one essential dogma: free interpretation is only a secondary truth, a consequence, which must in no case be allowed to ruin the one great foundation of the faith. In other words, the orthodox are Christians before they are Protestants. Christianity, as revealed in the Bible, is eternal truth, Protestantism only a necessary historical development. For the Reformers of the sixteenth century the cry for intellectual freedom was not the most pressing. They were impelled, not by logic, but by piety. The resistance of the Church to their demands for reform threw them into opposition; Liberalism, the doctrine of all minorities-even the Catholic Church, whenever she is in the minority-became their weapon, but it was not their end. "We claim liberty for ourselves, because we are right; we deny liberty to you, because you are wrong." 'This way of reasoning, faulty though it seems to the 
dispassionate critic, is irrefutable in the eves of the believer; thus the same Government would be blamed for persecuting a Christian sect and praised for prosecuting even peaceable anarchists. From the days of Luther and Calvin, Protestantism has had a double aspect, conservative and revolutionary, the champion of liberty without, a religion of authority within. The orthodox, therefore, are not untrue to the tradition of their faith.

This faith had become dearer to them through three centuries of struggle, of persecution, of perseverance. No man would have remained a Protestant unless the great dogmas of Protestantism were vital to him. If he believed in freedom of thought more than in the Bible, the ever-growing party of Rationalists and Voltairians was there to welcome him. But no: he clung to his few essential dogmas all the more tenaciously because they were so few, and his only defence against infidelity. A Catholic has all the resources of the Church to rely upon: a Protestant has the Bible only. If he lets that go, especially in a country where free-thought is powerful, he cannot remain a Protestant.

Thus both the great parties within French Protestantism have their justification in tradition and in reason. A constant struggle between them is inevitable; in the eyes of the liberals, the orthodox are but illogical Catholics, and for the orthodox, the liberals are half-hearted or hypocritical free-thinkers. This war is bitter, because it is waged by earnest men, whose dearest interests in this life and in the life to come are at stake; because it is waged within a narrow field, where no blow can miss its aim ; because it is a fratricidal war, in which treasures of love are turned to gall, in which each combatant suffers as much from the wounds he inflicts as from those he receives.

The crisis of the struggle occurred just during the period we are studying, from 1848 to 1872 . The evolution of French Protestantism remained parallel with the general evolution of the country, without merging into it. There had been a Catholic revival in the early years of the century; there was, a little later, a Protestant revival, mainly under Wesleyan 
influences. In both cases the resistance of the Rationalists, the disciples of eighteenth-century philosophy, had to be conquered; after 1848, Protestantism, like Catholicism, had to face a more formidable enemy than mere rationalism-the scientific spirit. Protestant orthodoxy, like Catholic orthodoxy, found it necessary to affirm and define itself: to the proclamation of Papal infallibility of 1870 corresponds the Declaration of Faith of 1872.

The Revival had not been essentially an ecclesiastical or a theological movement; it owed its success to its appeal to the deepest emotions, as well as to its practical activities. It did not rely on forms and formulæ; indeed, the movement was not encouraged at first by the conservative Established Church. In its policy, in its methods, the Revival seemed, on the whole, liberal. But, without any desire of going into theological subtleties, without giving any prominence to intellectualism, it laid such stress on the dogma of the Atonement, and, of course, on the literal inspiration of the Bible, that it re-opened the era of theological strife. So long as Protestantism had been, first of all, a tradition, all men born within the Church could accept its tenets unquestioningly, whatever their own intellectual tendencies might be : their faith was part of their inheritance, like their names or their national allegiance-something to be accepted and honoured without discussion. When the faith was, as it were, vitalised and individualised, when it was made to consist in the personal, unreserved acceptance of one dogma, a schism was to be feared.

The Synods of 1848 and 1849, convened with the aim of preventing such a schism, could not restore genuine unity. In 1849, Frederic Monod and Agénor de Gasparin founded the Union of French Evangelical Churches, on the basis of Revival theology. These Churches were independent of the Establishment, which they considered as latitudinarian. On the other hand, in July, 1850, appeared the first number of the Revue de Strasbourg, devoted to the reverent but fearless investigation of religious truth. The task was difficult; until about 1858, with such contributors as Colani, Reuss, Scherer, the Review was not unequal to it. But every year the incompatibility between the 
orthodox and the scientific points of view was appearing more flagrant. When Scherer practically abandoned historical Christianity and went over to free-thought, the old confidence and enthusiasm were well-nigh ruined. Through prodigies of tolerance and diplomacy, the life of the Reriew was prolonged until December, 1869. A last article by Colani acknowledged in veiled terms the failure of this noble effort.

Probably the most typical episode of the struggle was the conflict between Athanase Coquerel, junior, and Guizot. The two causes could have no worthier champions. Coquerel was a brilliant young minister, beloved of his congregation. His father was one of the noblest representatives of Liberalism, famous alike as a philanthropist, a preacher, and a theologian; in 1848, Paris had elected him to the Constituent Assembly. Guizot was the illustrious historian and statesman who for eight years had seemed the actual ruler of France. Coquerel's Liberalism was thoroughgoing and outspoken; he did not conceal his sympathy with Renan, and consented to serve on a committee for the erection of a statue to Voltaire (1867). In 1864 , in spite of the support of his congregation, he was judged and condemned by the Presbyterial Council, in which Guizot took a leading part. This decision roused great opposition. In the following presbyterial elections, Guizot, in spite of his fame, anthority, and undoubted services, was elected only at the second ballot, and by the narrow plurality of eight votes. He was accused of assuming the rôle of a Protestant Pope. For twelve years, until after Guizot's death, Coquerel was kept out of the Establishment.

It was Guizot again who, in spite of his eighty-five years, was the dominant influence in the Synod of 1872 , for which he had obtained from his former rival Thiers, then President of the Republic, the necessary governmental permission. This Synod was the culmination of a series of efforts for haring tho Protestant faith authoritatively defined, both dogmatically and legally, so as to exclude the liberals from the fold. Snch a Synod looks for all the world like a miniature Catholic Council. The Confession of Faith which it adopted may seem reasonable and moderate: but it was meant to be the test of orthodoxy; 
therefore it limited the Protestants' birthright of personal interpretation. For the liberals, such a limitation of liberty was equivalent to its suppression. The aged Pope of the Huguenots triumphed; orthodoxy carried the day by sixty-one votes to forty-five. But the long-deferred schism-secretly desired by members of both parties-finally took place, and in spite of recent efforts it seems irremediable.

\section{Guizot.}

With Guizot we return to the main stream of French life and literature: for he was a statesman as well as a Church leader, and an admirable writer as well as a thorough scholar. Indeed, there are few lives more complete than his, covering as it did eighty-seven years under the twelve political regimes that France has known within less than a century. He reached the summits of fame and power. Journalist, professor, historian, administrator, political man, Cabinet Minister, Premier, he was the mainstay of a dynasty, for seven years the ruler of France under King Louis-Philippe, and one of the masters of Europe. But he was as unpopular as he was admired and respected; as selfish for his class as he was disinterested for himself; as blind to the state of the country at large as he was clear-sighted in his bourgeois Parliament; austere, but relying, like Walpole, on political conscience-jobbing; high-minded, but flourishing before the electorate the motto: "Enrichissez-vous!" (Get rich!); a great historian, but a poor prophet, who explained with assumed infallibility the progress of civilisation, and, not long before the Revolution of 1848, declared: "The day of universal suffrage will never come" ; a great intellect, but with blinkers; a great heart, but outwardly cold; a great leader who wrecked his party; a great Conservative, who, through sheer blundering and obstinacy, plunged his country into a revolution.

Such was F. Guizot at sixty-three, on the morrow of the upheaval which had overthrown him, and the dynasty he served, and the class he represented. Then perhaps more than ever, the true greatness of the man revealed itself. Exiled from politics, universally unpopular, by no means wealthy, the old athlete did not lose his courage, nor even his serenity. Three purposes 
were to fill his life, each sufficient to engross the energy of a younger man. He would complete his History of the Rebellion, the Protectorate and the Restoration, commenced twenty and thirty years before-and the new volumes are fresher, more brilliant than the old. He would write the Memoirs of his own Times, a calm and lofty defence of his political career. And to crown all his labours, he would undertake a great apology of the Christian faith.

This apology was no new idea with him, but the dream of his early manhood realised in old age, after the storms of an eventful lift. Undoubtedly the conditions under the Second Empire, the intense interest in religious questions, the renewed attacks against Christianity, the universal conflict between conservation and revolution, impelled him and helped him. But he was following, first of all, the logic of his own destiny.

Guizot was of old Protestant stock. He was born at Nîmes two months before the exceptional regime imposed upon the Protestants was abolished by Louis XVI. His education, he tells us, * was Christian, pervaded with earnest sentiment, but vague from the dogmatic point of view. From the South of France he went to Geneva, after the death of his father, a vietim of the Terror. He found there another kind of Protestantism, based on institutions, practices, and traditions rather than on strong feelings or precise beliefs. In Geneva, the eighteenth century had enervated the sixteenth: Rousseau's spirit was there as well as Calvin's. In Paris, his Protestantism, already more philosophical than religious, was in danger of "evaporating," when, strangely enough, the most dangerous chapters in Gibbon, which he read with a view to editing them, shook his Rationalism. The growth and spread of Christianity, as reported by the infidel historian, seemed to him miraculous (1812). Later on, his studies and his political opinions brought him into close touch with the history of the great liberal comntries, England, Holland, the United States; he could not fail to see the part played by Christianity, under its Protestant form, in the development of these nations and in the firm establishment of true liberty.

* Revure des Deux Mondes, September 1, 1869, p. 27. 
According to Guizot, therefore, it was mainly the study of history that brought him back to Protestantism and confirmed him in it. His religion was certainly not part of his historical system, which, in its turn, was not consciously subordinated to his political opinions; but such rigid unity prevailed in Guizot's life that these three independent lines of thought were strictly parallel. In religion as in politics he was a traditional liberal; in other words, he believed in liberty, but only within the limits of an authoritative document-the Bible and the Charter. History and apologetics, in his hands, consisted in reconciling authority and liberty, by proving the reasonableness of the documents which define and guarantee liberty, or, to use a favourite expression of his, by expounding their philosophy.

The three series of his Meditations on the Christion religion are such a demonstration. They are purely intellectual, theoretical. Guizot does not insist on the practical side of religion. No doctrine, he says, can rest safely on the basis of mere usefulness. The question is not one of efficiency, but one of truth. Nor is he satisfied with the sentimental adhesion to the moral teaching of Christ: "[Some maintain] that this moral teaching is sufficient, and indeed is the whole Gospel. They disregard absolutely the bond which unites, in man, thought with feeling and belief with action. Man is greater and requires more than these shallow moralists claim for him, and in the deep instinct of his soul, the law of his life is necessarily connected with the secret of his destiny. Christian dogma alone imparts to Christian morals the sovereign authority needed for governing and regenerating mankind." * In religion even more than in politics, Guizot was a thoroughgoing doctrinaire.

His reasoning can be summed up in the following terms: There are for us eternal and universal problems, such as the origin and destiny of man and of the world, liberty and providence, evil and salvation. These problems philosophy cannot solve; Christianity alone offers a solution.

Of the impotence of philosophy Guizot gives us two different proofs. The first is derived from history: all possible systems have been tried. They can all be reduced to four-sensualism

* Méditations sur l'Essence de la Religion Chrétienne, 1864, p. 286. 
and idealism, scepticism and mysticism; and their eternal conflict shows that none is absolute and final. All the great systems of the present day-spiritualism, rationalism, positivism, pantheism, materialism, scepticism-are examined and found wanting. The second proof is logical : philosophy is purely human, and cannot reach beyond the limits of human nature. Guizot is as decided as Littre or Spencer on the impossibility for the unaided human mind to transcend the bounds of science.

All metaphysical systems being thus rejected, Guizot proceeds to expose the essentials of Christianity, which, according to him, are contained in only five dogmas: creation, Divine providence, original sin, the Incarnation and Redemption. Creation remains the only explanation of the existence of the world, "spontaneous generation and the transformation of species being arbitrary hypotheses, rejected by science itself." Providence is proved by the universal instinct of prayer. Original sin and its transmission is a doctrine in harmony with human experience, and solves the otherwise baftling problem of the origin of evil. The Incarnation is possible, for all religions have held such a belief, and "was not the creation of man himself an incarnation?" It is true, for the revolution made by Jesus is absolutely different from that made by any man. As for the Redemption, it is reasonable, for the belief in the saving virtue of voluntary sacrifice is also universal.

Such is the logical structure of the apology. Without discussing in detail the selection of the five essential dogmas and of the proofs he adduces in favour of each, we have to face one great difficulty: Guizot exalts religion on the ruins of philosophy, and his religion is, to all appearances, a philosophy. Every logical demonstration of Christianity will be open to this objection: if Christianity can be proved to be "reasonable," it becomes a metaphysical system like the others, and can be ruined by the same arguments. So, in his answer to Janet's criticism, Guizot was obliged to abandon all his logical apparatus. "Christianity may be put in philosophical form," he said, " but it is not a philosophy ; it is not an attempt at the discovery of truth, it is truth itself; its dogmas are not theories, hypotheses, they are facts." How can these trenchant affirma- 
tions be substantiated? By the further assertion that Christianity is not a system, but a history-the history of the relations of God with mankind. "The miracles take naturally their place in such a history." * The whole question is therefore whether this history is true.

Guizot, of course, did not doubt its truth; no man would doubt it, he affirms, if he were not biased by the rationalistic prejudice against miracles. If miracles were once frankly accepted as possible, as undoubtedly they are, the Bible would offer no difficulty. But is this assertion perfectly safe? First of all, if we brush aside the rationalistic objection to miracles, should we limit ourselves to Biblical miracles, or should we accept all miracles indiscriminately, wherever they happen to be reported? Are not later miracles, in the Catholic Church for instance, at least as well authenticated as those of Judea? To maintain that Biblical miracles alone should be given credence, because the Bible alone is a miraculous book, is simply begging the question. Besides, are there not other difficulties? Are there not discrepancies, contradictions, material impossibilities of a non-miraculous character? Guizot's demonstration was luminous for those who accepted blindly his conclusions from the outset.

This apology, it will readily be noticed, is not specifically Protestant. Guizot considered as essential only the dogmas which are common to all great historical Churches. The purely Catholic dogmas, like transubstantiation or the remission of sins, he does not deny or dispute, but simply ignores. As a matter of fact, his demonstration, based on authority and history, is rather Catholic than Protestant; there is no touch of individualism in it. Without ever being tempted to abandon the Church of his birth, Guizot drew gradually closer to Catholicism. He hoped, not for a reunion, but for a reconciliation of the Churches. For the Catholics, not only for the most liberal among them, but for the Pope himself, he had nothing but words of sympathy and respect. He reserved all his power of denunciation for the liberal Protestant. "No compromise with heresy," he said in the case of Coquerel. "The Council of the Church must be the

* Revue des Derax Mondes, September 1, 1869. 
defender of the souls of Coquerel's flock, and decide for them the supreme question of faith and life" (February, 1864). This rigid ecclesiastical doctrine, disregarding the rights of private interpretation, is essentially Catholic.

Yet Guizot was mistaken if he hoped for a genuine reconciliation of the conservative Churches. In the eyes of orthodox Catholics he remained a heretic. When he denounced the daring and dangerous innovations of the liberals, the Romanists could tell him: "Bossuet foresaw your predicament two centuries ago. There is no orthodoxy without a Church to define and enfurce it; there is no Church but the historical Church of Rome; all others are schismatic or heretical. Authority cannot compromise with free-thought."

In religion, as well as in politics, Guizot attempted an impossible task; he believed in limited revolutions. He thought the flood-gates could be left ajar for a moment and then closed more stanchly than before. With his inborn faith in conservatism and authority he ought to have been a Catholic and a Legitimist. The irony of fate would have it that the King he served reigued by the divine right of the barricades, that the Church of his allegiance rested originally on a revolt of the individual conscience. He would have stopped religious evolution about the middle of the sixteenth century, political evolution about 1830 ; but who can say to the progress of human thought, "So far shalt thou go and no farther"? Thus his political life ended in disaster, his religious life in a victory more bitter than many defeats. But although he was in all things an obstacle rather than a guide, we cannot help admiring Guizot, his untiring activity, his indomitable will, his loftiness of purpose, his devotion to the ideal, and even his unshakable belief in his own infallibility.

\section{Scherer.}

The life of Guizot has the majesty of immobility-his mind grew, his character developed, but like a tree, which adds each year a new ring to its immovable core and strikes deeper roots into its native soil. The career of Scherer has the dramatic interest of evolution: he moved slowly, cautionsly, reluctantly, 
without missing a single step, without retracing any, from strictest orthodoxy to absolute free-thought. In these two earnest and consistent lives we find exemplified the two main principles of Protestantism: authority and liberty, the Divine inspiration of the Bible and the rights of the individual conscience.

Scherer, like Guizot, was born of Protestant parents. But Guizot was of pure French Huguenot descent ; Scherer's family connections were cosmopolitan. Guizot spent his youth in his native South or in Geneva; Scherer was educated in Paris, and attended the courses of a State institution. These differences alone would explain why Guizot's faith, although it did not retain at all times the same degree of ardour, never knew any life-and-death crisis, whereas Scherer's, exposed earlier and to more dangerous influences, had already waxed and waned, succumbed and triumphed, when he was only fourteen. At sixteen, in 1831, he was sent to Monmouth, England, "as an heroic remedy for his state of listlessness, discouragement, and despair." The remedy proved successful. The influence of his host, Rev. Thomas Loader, transformed the shiftless boy into a hard-working Christian man. In 1832 he was able to write in his diary: "Christmas : conversion." His Protestantism, therefore, was not merely a heritage, but a new conquest; and the faith he adopted, on the eve of manhood, was not the somewhat formal system of eighteenth-century theology, but the purest doctrine of the Revival. "Yes," he wrote in his Commonplace Book, "justification by faith is the way of salvation; it is the means which God has used to bring man to sanctification, which is his end."

His vocation for the ministry became unconquerable. $\mathrm{He}$ took a theological course at the University of Strasbourg, under the direction of Ed. Reuss, a great scholar, a man of sterling character, impartial and bold, to whom Renan has paid many a well-deserved tribute. But whilst he profited by the scrupulous method of his teacher, Scherer was more uncompromising than he in his orthodoxy, and, rather than the scientific liberalism of Reuss, he held the doctrine of Gaussen on the plenary inspiration of the Scriptures. The seventh 
proposition of his thesis for the theological licence was: "That all inspiration is necessarily literal" (1841).

In 1845 he became a Professor in the Oratoire, or Free Divinity School, of Geneva. This school had been founded in 1831, under the influence of the Revival, in order to defend the doctrine of plenary inspiration, and Calvinistic theology in all its strictness, against the relaxed teaching of the State Faculty. It had for its president the well-known historian Merle d'Aubigné. Scherer's orthodoxy was entire. He refused to himself the right of choosing passages in the Bible as more evidently inspired than others: "You believe that such or such a passage is divine? But then it is not God you believe in, it is yourself. One does not accept fully an anthority which one could have refused to recognise." His faith was too absolute to be afraid of the truth in any form, and he would begin his lectures with the invocation: "O God! Thou art the God of truth. We are seeking truth. Thou alone canst make it known unto us. Amen." He was at the same time too clearsighted not to understand the dangers of this search for truth. "The apprenticeship of a theological student is hard. The uncertainty into which his mind is thrown about so many things which seemed to him simple and certain before, is a source of cruel agitation. ... It is a sitnation from which one cannot come out victoriously without prayer and tears." * $U_{p}$ to that time (1848), after a few years of boyish fermentation, Scherer's life had been one of admirable unity, of single devotion to truth, of unhesitating belief in the source of all truth, the Christian religion; then began a soul's tragedy, quieter than Jouffroy's, but no less harrowing in its unobtrusive, relentless, and slow development.

He was professor of Biblical exegesis: problems arose in his mind which he could not solve, doubts which he could not allay. Tortured by doubt, he sought God's support in prayer-and it is perhaps the noblest trait in his life that he did not pray for peace, but for truth: "O God! grant me to be true-true especially as to Thee, true in Thy service, for that is the primal truth, from which all other truths are derived. . . " †

- Gréard, Scherer, 72.

$\dagger$ August 15, 1848. 
"Give me truth, O God! so that I may be all light, without any mixture of darkness and of error; give me sincerity, so that I may let the truth I know be manifested without any veil of reticence. Let my heart within me be like the heart of a newly-weaned child!" * The first stage of the struggle lasted nearly two years. On December 28, 1849, in closing his lecture, he announced that it would be his last in the Oratoire.

Scherer, even then, remained orthodox in all his views, except on the doctrine of literal inspiration. But he saw clearly that this doctrine involved the whole question of authority in religion. When he sent his resignation to the Director of the Oratoire, Scherer passed over from the conservative to the liberal side of Protestantism.

Here we cannot help thinking of Renan's case, so strangely similar to Scherer's. Renan, like Scherer, moved by scientific scruples, had to give up his belief in literal inspiration. But, brought up in a Church based entirely on tradition and authority, he passed almost immediately, with hardly any apparent struggle, from orthodoxy to scientific independence. If you remove a single stone, the whole edifice of Roman Catholic theology collapses irremediably. The inner contradiction of Protestantism, in such a case, is a source of strength: the two principles, authority and liberty, are able to combine in a thousand different ways and proportions; it is possible to cover almost the whole range of human thought without completely losing touch with Protestantism. Renan's evolution was complete in a few months; Scherer's took twelve years. $\dagger$

After breaking with the Oratoire, Scherer remained in Geneva for ten more years, a theologian and a Protestant still. Formerly the hope of the stanchest conservatives, he became one of the leaders of the liberals. He found himself in harmony with the newly-established Revue de Strasbourg; he opened a

* Gréard, Scherer, p. 87.

t The Protestant faith dies harder than the Catholic, being at the same time simpler and less consistent; on the other hand, ecclesiastical habits survive the loss of the Catholic faith much longer than that of the Protestant. Renan became a radical free-thinker much more rapidly than Scherer, but he remained a priest at heart all his life, whilst Scherer soon ceased to be in any way a minister. 
private course which, in spite of violent opposition, attracted large and appreciative audiences. Excommunicated, ostracised, saddened, but not embittered, he defended his faith inch by inch.

He defended it against his opponents who doubted it, but chiefly against the logic of his own thought, which, relentlessly, was biting into his old beliefs. For the doctrine of anthority, which he had to abandon, he tried to substitute that of the inner feeling, the harmony between the revelation in the Book and the revelation within our hearts. "It is to the soul that the whole Gospel is addressed, it is by its essential affinity with the soul that it establishes its claims." * But all the books in the Bible, all the chapters, all the verses, do not appeal equally to our souls; some non-Biblical writings possess the character of spirituality to a higher degree than some of the sacred books; there is more "inspiration" in the Imitation than in Chronicles. "To limit the Spirit of God to the Bible, to deny the identity of the Spirit of the Bible with the Spirit of the Saints in all centuries, is a crime against that very Spirit and a lie of theology against faith." The canon of the Bible is merely the classical literature of our religion, but the Bible is neither totally nor exclusively inspired.

When he reached this point (1854) Scherer could affirm that "the destiny of the Bible and the destiny of holiness on earth are indissolubly bound together," but he was no longer, in any definite sense of the term, a Protestant. What he was he himself did not know: but he suffered. "I am not made, I feel it, for a time of universal transformation like ours; my sympathies are with the past, and yet human affairs are carried along by a current against which we cannot go. Thus I see myself borne by the convictions of my intellect towards a future which inspires me neither with interest nor with confidence." $†$ And he wrote about Bishop Colenso pages in which rings the accent of a personal confession: "Some of the men who have most openly broken with the tradition, started with the most childlike, implicit, obstinate faith. They did not doubt in order to get rid of a doctrine, the holiness of which weighed 
upon them: the did not den it because it was their interest so to do; it Tas in spite of themselres that their faith left them. Far from seeking out objections, the hare recognised their weight with reluctance. The rielded to eridence. Their souls, when they saw for the first time the abrss gaping before them, were seized with immense and grierous terror; they cast themselres on their knees, the struggled with tears, they tried all remedies, had recourse to all adrisers. Feeling the thoughts that had been their jog and their strength escape from them, realising the worth of all that was about to fail them, not conceiring that anthing could erer fill the racant place. accustomed to considering dogma as the food of spiritual life and the only safegrard of human tirtue. it seemed to them that they rere going to fall endlessly into abrsmal darkness. Trent times the resolved to doub their doubts, ther decided to dose their eyes to inis hateful light. the made deliberate efforts to beliere-and erer the found themselres confronted with the absolute empire that Truth holds on honest minds. Nas, we hare here something more than the mere ascendaney of eridence. If the most ferrent believers, if saints themselves doubt at present. it is not on account of the seduction of speculatire ideas, it is not eren on account of the power with Which sereral reshits of modern criticism impose themselres upon us: it is chieft through the need of remaining consistent with themelres: acenstomed to listening to their conseience, they cotild not resist it. Sincerity is for them sueh a high and sacred tirtue that eren their faith has to be sacrifced to it. The confiet in which ther are engaged is a conflict of morality with dogma, of uprightness of character with lopalty to the flag. In a word, if the essence of religion be Justice and Truth, Te may sar that these men are led to unbelief through derotion to religion itself. Such is the contradic. tion under which many souls are groaning at present! Such is the truly tragie spectacle witnessed by the nineteenth centurt.'

After passing from theology to metaphysics, from metaphysics to natural science (without mentioning Comte. Scherer seems

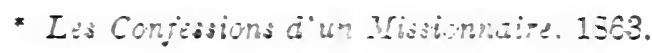


to accept the law of the three states), would the human soul complete the cycle, and, harrowed by conflicts, revolutions, and catastrophes, return from materialism to faith again? In 1857, he expressed such a hope; but could it well be termed a hope? For he expected that mankind would begin again the weary round-endless motion without progress.

His final philosophy, if by such a name may be called the negation of all philosophy, was universal relativism, in which he found, not joy, but precarions rest and a sort of weary peace. "The edifice of the ancient world rested on the belief in the Absolute. Religion, politics, morals, literature, everything bore the mark of this notion. There was then neither doubt in the minds nor hesitation in the acts : every one knew how to decide. One knew of two causes only in the world, God's and the Devil's; of two camps among men, the good and the wicked; of two places in eternity, on the right hand and on the left of the Judge. Truth was all on one side, error all on the other. To-day, nothing for us is truth or error: we must find other words. We see everywhere nothing but shades and degrees. We admit even the identity of contraries. We no longer know religion, but religions; ethics, but customs; principles, but facts. We explain everything, and as it has been said, the intellect approres in the end whatever it is able to explain. Modern virtne is all summed up in toleration, that is to say in a disposition which our ancestors would have considered as the worst sign of weakness or treason. As for me, I confess, I camot consider this revolution, the ancient world that one word has ruined, so many wandering souls, so many uprooted beliefs, so much darkness and sadness in our hearts, the end of so many strong and noble thingsI cannot think of all that without being reminded of the Voice which sounded over the seas of old, and told mankind in dismay that 'Great Pan was dead.' 'At which cry,' relates Pantagruel, 'all were struck with terror; and the last word was not ended but great sighs were heard, great lamentations and terrors on earth, not of one person, but of many.' Yes, the Voice has sounded again through space, announcing the end of another age and the last breath of another God: the 
Absolute is dead within our souls: who shall raise it to life again ?" *

There is despair in these eloquent lines, the despair of Vigny, Proudhon, Leconte de Lisle; and the "cry of agony" of Madame Ackermann rings like an echo of Scherer's. He had staked his all on the pursuit of truth: "Life was given unto us," he said, quoting Saint-Martin, "in order that every one of its minutes may be exchanged for a particle of truth. I am not among those who are able to boast of an existence thus filled; yet I dare to bear this testimony to myself: Yes, thus I too understand life." + Athirst for truth, for nearly twenty years in possession of absolute truth, his soul conld not find happiness among the ruins which his intellect had made. Yet Scherer did not die of his metaphysical wound like Jouffroy. Relativism, cheerless as it is, precludes absolute despair as well as absolute knowledge. It cannot be a doctrine of hope, but it can teach resignation. The crisis was long and Scherer suffered; but even before it was over he had become a literary critic of great authority; he was soon to be one of the best champions of political Liberalism in the daily press. Life was worth living, although the Absolute was in its grave. Engaged in congenial work, at peace with his conscience, respected even by his enemies, he ras able to reconquer, not merely tranquillity, but happiness. "How happy we are!" he would exclaim in his old age. In this again, his case was parallel with Renan'sRenan, whose cheerfulness seemed so puzzling and even so offensive to M. Jules Lemaitre.

He would probably have been at a loss to reconcile his positive happiness with his philosophy. We are told $\ddagger$ that he had thonght of writing a treatise on the subject, and had to give up the attempt. His last words on moral philosophy are merely words of resignation. "To be happy is to have measured happiness and one's self; there is no surer way of not quarrelling with life than not to expect too much from it." "The universe is a fact: we do not control it; we have nothing

* Essay on Hegel (Revue des Deux Mondes and Mélanges d'Histoire Religicuse).

† Mélanges de Critique Religieuse, Avertissement.

† Gréard, l.c. 235. 
to do but to accept it. . . . Dry and bitter though they be, these truths are not barren. It is something to have learnt that among the problems which have most engrossed the human mind there are some which have no solution, and even no meaning. And the acceptance of things as they are, the habit of taking them as the ineluctable conditions of life, is a pretty good teacher of resignation. If one does not suffer any the less, one is less irritated by suffering; anguish is no longer mingled with bitterness, regrets with anger. The protest of the human moral sense against the immorality of mature and history remains; this is desirable; but it loses the feverish and childish form of rebellion. 'O Universe!' said Saint Marcus Aurelins, 'what thon wilt, that will I also.',

There was faith in the orthodoxy of Scherer's young manhood; there was no less faith in the honest doubt which filled his mature years; there seems to be none left in the stoicism of his old age. So this life of noble efforts ended with words of resignation-resignation, which is naught but the quietest form of despair. This alone would warn us that there was in Scherer's destiny something wrong somervhere.

Yet it cannot be said that he erred, still less that he sinned. His reasoning was as faultless as his intentions were pure. He was not moved by love of destruction, for he struggled long against his own doubts; nor by intellectual pride, for he was no worshipper of human reason. We must pity him, but hold him blameless.

His misfortune, he saw this clearly, was to be longing for an unchangeable faith in an age of transition. He wals by nature a conservative, an orthodox; the Absolute had been his god, and he mourned for it long after it was dead in his soul. Compare his literary criticism with that of Jules Lemaitre: Lemaitre may defend authority and tradition, which are the deep instincts of his nature; but he does it with the tone and the arguments of a subjectivist, or, to give him the name he accepted, of an impressionist. Scherer preached Liberalism with the forceful earnestness of a theologian : while expounding relativism, he remained dogmatic. One cannot read his article on "The Metaphysical Illusion," his review of Renan's 
Philosophical Dialogues, without being struck-and possibly irritated-by the trenchant expression of his scepticism. $\mathrm{H}_{\theta}$ was the infallible Pope of universal uncertainty.

Scherer was only forty-five when he emerged from his great crisis; many men have recast their lives at a more advanced age-Lamennais was fifty when he left the Church-and we may wonder why Scherer did not go beyond mere relativism. But his critical faculties had developed during a twelve-year battle against his most cherished beliefs: his scepticism was now alert and formidably equipped against any new system. Besides, he had loved his old faith so dearly that he shrank at the thought of giving it a successor. Thus a soul meant to be filled with ardent, umhesitating convictions was to remain empty, and, resigned though it seemed, it could not but mourn the irrecoverable faith.

Yet it was well for Scherer that he did not recoil; not only his sincerity, his intellectual courage, will remain his eternal. honour, but in this life they saved what could be saved of his happiness. Wavering would have but prolonged his agony and forfeited our respect.

\section{Quinet.}

Guizot was the champion of Christian orthodoxy; for him, Protestantism meant a faith based on the only legitimate authority-the Bible-and on the Bible alone. The liberals insisted on the rights of the individual conscience, a principle which, carried out by Scherer with fearless consistency, led him away from the Church altogether. There is a third aspect of Protestantism : historically, it is a reformed religion, freed from the superstitions and abuses which had crept into the traditional Church. It should therefore appeal to the men who are neither dogmatists nor investigators, but practical Christians, and who are dissatisfied with the administration and the policy of the Roman Church. In a country like France, Christian by tradition, but impatient of "clericalism," such men, Reformed Catholics rather than positive Protestants, are bound to be numerous.

Circumstances, under the Second Empire, seemed favourable 
to such a movement away from Rome and towards Protestantism. The old eighteenth-century hostility against Christianity as a whole was almost extinct. All the leaders of liberal thought, all the great Romanticists-Lamennais, Lamartine, Hugo, Michelet-had paid glowing tributes to the traditional faith. There was no lack of genuine, conservative religious feeling. On the other hand, the hoped-for reconciliation between the Church and Liberalism had failed; Rome was becoming every year more reactionary in her temporal policy, more intolerant of modern tendencies, more dceply committed to unacceptable forms and beliefs. It was increasingly difficult for many earnest Christians to remain Catholics, with Veuillot ruling the Church in France as a sort of Papal legate. Protestantism would have enabled these men to retain all the essentials of their religion without sacrificing their dignity as thinkers and as citizens.

The most eloquent apostle of this movement was Edgar Quinet. Brought up by a Protestant mother, for whom his admiration was as boundless as his love, he studied for ten years at Tübingen and other German universities, and married the daughter of a German minister. So he was free from Voltairian prejudices. Religion was ever the centre of his historical as well as of his literary works. He was one of the first men in France to recognise the all-important influence of religion in human history, and in this respect Fustel de Coulanges and Renan, although greater than he, did but glean in his field. He was rather a mystic philosopher than a historian. Picturesque details, the psychology of individuals, the technicalities of institutions, were for him points of secondary importance. His one aim was to study the laws of collective development, and for him, as for Bossuet, these laws were naught but the expression of God's Will. The old doctrine of Providence was rebaptized "philosophy of history," and under its new name became one of the idols of the early nineteenth century. Quinet was eren more dogmatic in his exposition of God's purpose with mankind than Bossuet himself. He assumed quite naturally the attitude of a hierophant. In his mind, history became a branch of theology, or rather a substitute for theology.

Except for this theological colouring, his interpretation of 
history, before 1848, did not differ from that of the other Romanticists. Like them, he believed in the Rights of Man, and in liberty as the first of them all. Liberty meant both national independence and democracy; Quinet was a patriotWaterloo and the treaties of 1815 rankled in his soul-and he sympathised with all oppressed and struggling countriesGreece, Poland, Italy, later Rumania. He hated the Catholic Church as the arch-enemy of liberty and progress, and admired the Revolution of 1789, which had proclaimed the new gospel. Since that great renovation, France was a Messianic people, the "heir of Jesus Christ." Napoleon personified in Europe the French ideal; he was the crowned apostle of nationality and democracy. But all great benefactors of mankind have to expiate their daring through martyrdom: Waterloo corresponds to Caucasus and Golgotha.

During the Second Republic, Quinet played a creditable, though not a leading part in French politics. From the Coup d'Etat to the fall of the Empire he remained in exile. After 1859, at least, this exile was voluntary; it was, like Hugo's, a protest against a regime based upon force and fraud. These new circumstances had some influence on his opinions without altering them radically. Isolated, he became more original; defeated, he was less optimistic, and he gained in both directions.

In his Christianity and the French Revolution (1845) he had opposed the "new dogma" of the sovereignty of the people to the Catholic doctrine of Papal infallibility. Democracy was then a political and religious panacea: the Revolution was "truer to the spirit of Christ than the Church." The spectacle of France, the chosen nation, "Humanity's right arm," unanimously condoning the crime of December, had a sobering effect upon him. Had he unreservedly believed in the new dogma he had so eloquently preached, he should have bowed before the elect of God and the people. Quinet refused to accept the apparent verdict of fate. He admitted as a dogma the liberty of our moral personality, the possibility for us to progress through self-discipline; in other words, he reverted to the religion of conscience and responsibility, without abjuring 
the fatalistic religion of Providence and Democracy. The tendency had been for many years to minimise the infiuence as well as the responsibility of individuals; heroes were but the instruments, geniuses only the living symbols, of immense collective evolutions. Quinet restored the notion of man's spiritual autonomy. In this the influence of his Protestant mother is undeniable. This exalted moral sense inparted a stronger originality to his writings and gave his life its flawless dignity.

The result of this individualistic evolution was that, whilst remaining a democrat-or rather a Republican-in politics, Quinet recanted his former "Demolatry." His Rerolution (1865) is far from being a dithyramb like the histories of Michelet and Louis Blane, or even the earlier and more conservative narrative of Thiers. At the same time as MortimerTernaux, ten years before Taine, he refused to be dazzled any more by heroie legends. "Idolatry," he said, "is no longer" permissible. Away with prejudices; away with sanguinary systems; away with historical fetishes-Cæsar or Robespierre; away with the deification of the People!" So fearless was the attack that in spite of his past services, his integrity, his talent, his irreconcilable opposition to the Church and the Empire, Quinet was threatened with excommunication by the democratic party.*

The Revolution failed, said Quinet, and left France in a state of latent civil war, becanse it stopped short of its main task : a religious renovation, a new Reformation. Religion is the very basis of society: a country whose nominal religion is at odds with the rest of its civilisation is fundamentally unsound. Now, the Rerolution, while it destroyed the last ruin of the Middle Ages in civil and political life, left practically untouched the incarnation of the medieval spirit, the Catholic Church. "The Constitution of the Clergy" was a timid, half-hearted attempt. Chaumette and his worship of Reason, nuch more remarkable, were misunderstood and derided. Robespierre's cult of the

* Cf. Peyrat, La Revolution et le livre de M. Quinet, 1866. It scems that in his Lettres d'Exil the sharpest eriticisms against the French people have been attenuated by Mrs. Quinet when she editcd them for publication. 
Supreme Being was inspired by Rousseau's Vicaire Savoyard, and Rousseau as a religious teacher is disqualified on account of his tolerance, which respects even superstitions and leads to hypocrisy.* In religion, the Revolution destroyed nothing and created nothing.

What should the Revolutionists have done? They should have imitated the thoronghgoing methods of the great Reformation. Wherever it triumphed, it condemned the old religious institutions and set up new ones, and it was not until the old had ceased to be a danger, and the new had become part of the national organism, that religious liberty was gradually restored. The breaking of images, the banishment of priests, compulsory conformity, were integral part of the work of the Protestant Reformation, in Geneva as well as in England or in Sweden. Previously, in Marnix de Sainte-Aldegonde (1857), Quinet had shown that the Dutch Revolution owed its success to its uncompromising attitude towardis its adversaries. It is an illusion to think that force is powerless against a Church, although it may be futile against a belief. The French Revolution was despotic in politics and liberal in religion: it should have been just the reverse. The massacres of 1793 were odious, because "their violence was out of proportion with their cause. The massacres of Moses have not harmed Judaism, nor those of Mohammed the Koran, nor those of Alva Catholicism, nor those of Ziska and Henry VIII. the Reformation. . . Men, even unbelievers, taken as a whole, have always shown great clemency for whoever sheds blood in the name of Heaven." +

A strange theory indeed, excessive, paradoxical, and above all unexpected; for Quinet was a humane and high-minded man. In the Jesuits, in Ultramontanism, he had denounced religious intolerance, and, at a time when he was less in sympathy with Protestantism, thanked God that France was free from the taint of exclusiveness. $\ddagger$ He was probably influenced by the example of England, a country which for two hundred years had found it necessary to defend its Protestant faith against an offensive

* The Savoyard Vicar urges the wisdom, nay the duty, for every one to remain in the religion of his family and country.

+ Revolution, xvi. 7.

$\ddagger$ Ultranontanisme, 241. 
return of Romanism, and which, even in 1860, was still intolerant to a degree. No country can live a normal life without religion: it is to Quinet's lasting credit that he affirmed this truth more emphatically than any of his contemporaries. Catholicism is incompatible with modern principles: this is not so evident, but it is after all a defensible idea. Now, what new faith would he substitute for the old?

In his letter to Eugène Sue on the "Religious and Moral Situation in Europe "* (1856), Quinet had already answered, unhesitatingly, "Protestantism," and, of all the forms of Protestantism, Unitarianism: "Certainly it would be an immense progress if the nations could be drawn away from Catholicism, which represents barbarous medicvalism, on to one of the most modern forms of Christianity. . . . And among these you cannot have failed to see that Unitarianism is the one most in harmony with our times, for while it preserves a shadow of Christian antiquity, and thus reassures the trembling spirit of the people, it also goes hand in hand with the most fearless philosophy. Who could not wish that the voice of a French Emerson, of a Channing, should be heard in the midst of our French society, in our provinces, in our workshops?"

Quinet was not content with preaching: through his influence a great religious movement was started at Brussels, and a Unitarian Church founded. But in France his words found no echo. The case of Maurice Sand, $\uparrow$ who, with his wife, became a liberal Protestant, remained an exception. Quinet himself, the apostle of Protestantism, never joined a Church, even the freest. Nay, whilst a Voltairian, Mérimée, a Positivist, Taine, asked for a Protestant burial, Quinet remained, in death as in life, a free-thinker, unconnected with any form of organised Christianity.

Why did he never take the decisive step? Perhaps he was too much of a Protestant, if Protestantism meant to him what the name seems to imply, to surrender to any Chureh a particle of his spiritual independence. It is a comparatively easy matter

* Le Livre de l'Exil: Lettre sur la Situation, etc., p. 453.

$\dagger$ The son of George Sand, a novelist of some merit; cf. G. Sand's Correspondence. 
to remain within the Church of one's childhood, or to return to it even after wandering far and wide; but after reaching middle life a man cannot adopt a new faith except as the result of a radical and irresistible conversion. Now Quinet, who was the disciple and the young friend of Creuzer, ${ }^{*}$ and one of the pioneers in France of the study of comparative religion, $t$ considered Christianity merely as a sect of the Church universal. His admiration for Protestantism was retrospective and moral ; in theology, he remained independent. He advocated a change of religious allegiance as a compromise between "Romish superstition" and his ideal of philosophy, as a transition between rigid ecclesiasticism and the absolute autonomy of the individual soul. "I do not expect the people to become philosophers all of a sudden," he wrote to Eugène Sue. Now such a conscious compromise gives satisfaction neither to the intellect nor to the heart. Men are not so humble-minded, or so foolish, as to accept anything as "good enough for them," if you imply that something better exists. Unless you have absolute faith in the religion you preach, how can you expect to convert a whole nation?

In contemporary France everything short of Catholicism seems to lack authority, tradition, efficacy, splendour, mystic appeal. Everything short of free-thought seems timid, illogical, halfhearted. Quinet was ever drawn to Protestantism by a sort of nostalgic attraction, and yet remained an outsider. He was thus a wandering spirit, too much of a Protestant, bent on individual salvation, to believe in sheer Romantic humanitarianism, and too much of a free-thinker to be a Christian. It may be true that men have treasures of indulgence for religious fanatics: but how shall we deal with this Churchless Huguenot, who advocated violence on behalf of an undefined creed, of a disembodied aspiration-a fanatic indeed, but a fanatic without a doctrine?

In 1870 Quinet appeared in a new guise with his large work on Creation. It is sometimes said that this book marked Quinet's conversion to the religion of science.t We cannot

* The author of the Symbolik: his religion, he said, was that of Proclus and Plotinus.

† Le Génis des Religions, 1842.

† Quinet had before criticised the religion of science: "The scientists also have their chimera: they imagine that science will soon take the place of 
accept this view. Like his friend Michelet, Quinet carried into the study of natural history the methods, the feelings, the style of his other works. Creation is yet another eloquent review of universal history, this time oxtended far beyond the narrow limits of human civilisation. Quinet read into geology and palæontology all his own moral theories. His disappointment with democracy for one thing: "It is possible for conscience to disappear for a time, from one people, even from almost the entire race, and to survive in a few rare individuals, forgotten, buried alive." * "Conscience is the result of a victory over our lower nature; [it] is not merely a gift; it is acquired through effort and strengthened by will; it grows by the same law which causes every being to struggle, to fight, to resist, in nature, in man himself. . . This sense of effort, this victory of will, prove that we are free."

This is all the positive faith expressed in this book. Man is little-an embryo, a "fragment of himself," and knows little: "What will happen to-morrow? We know not, we who aspire to eternity." + Perhaps a new race will wrest from us the sceptre of the world. This work, so different from the usual prean to science, ends in tones of doubt and melancholy. The last word of wisdom is the stoic resignation of Marcus Aurelius, $\stackrel{+}{+}$ and when Quinct speaks of the triumph of justice, it is not in the form of an affirmation, but of a prayer-a prayer mingled with anguish and almost with reproach: "O God, who in these days veilest Thy face, do not permit that justice should fail!" $\$$

No layman exeept Renan was more constantly interested in religinus problems than Quinet; and he treated these problems with a passionate carnestness which made Renan seem coldly rationalistic, almost Voltairian in comparison; no one assumed

religion. 'They do not know human nature. Religion and scienco are in definitely drawing eloser, but they will never merge into one: they are the asymptotes of the great human curve."-La Révolution.

* "If it should proclaim that wrong is right, the wholo human race, innumerable and degraded, would bo as naught compared with tho conscience of one just man."-Cr. ii. 397.

+ ii. 408.

+ ii. 413 .

$\S$ ii. ch. x. The New Spirit (1875) is in the samo strain, more optimistic, but even vaguer.-ii. 411. 
more naturally the tone of a prophet and of a preacher. Yet, when it comes to the point of defining the doctrine of this long life and of these thirty volumes, the reader is at a loss. Pantheism, Democracy, Stoicism? Who could tell?

Yet if religion is, not a doctrine, but an inspiration, and a law to live by, Quinet, ever haunted with thoughts of the infinite, ever faithful to the dictates of his conscience, ever devoted to the service of God and the people, was one of the most religious men that ever lived. He was neither a great thinker nor a supreme artist, but a noble soul. His life was his best work. He is one of the Saints of modern France.*

\section{Conclusion.}

In France, Protestantism, as the representative of authority, tradition, orthodoxy, is overshadowed by Catholicism : this Guizot himself willingly recognised. As the champion of individualism in religion, it merges inevitably into free-thought, as happened in the case of Scherer. For the compromise dreamt of by Quinet-a simpler creed, a purer Church, as a preparation for the reign of universal philosophy-there seems to be little room. We understand now why Protestantism, in spite of its glorious history and of its admirable elements, had so little influence during the period we survey; why its progress was so slow, in spite of apparently favourable circumstances; why the problems it offered were never of national scope. French Protestantism is a survival: many of its leaders know this and take pride in it. They do not welcome modern life. Their faith has the poignant and noble melancholy of a dying city; it would be a sacrilege to tear up its moss-grown pavement and to send trolley-cars rumbling along its deserted streets. Requiescat in pace!

* A small and well-meaning group, "The Union of Free-Thinkers and Free Believers " (liberal Protestants and religious-minded agnostics), seems to hold him in special veneration. 


\section{BOOK II}

\section{CHAPTER I}

\section{VOLTAIRIANISII}

\section{Decline and Revival of Voltairianism.}

There are at least two kinds of Voltairianism, as any standard dictionary will tell us : "Voltairianism : the principles or practices of a Voltairian ; the spirit, philosophy, and doctrine of Voltaire; witty and scoffing scepticism."

The spirit, philosophy, and doctrine of Voltaire? That far transcends mere scoffing scepticism, however witty. Faith in civilisation, in progress, in science; hatred of intolerance and superstition; unremitting activity ; effective, courageous benevolence: if this be Voltairianism, who would not, like Thiers in 1845 , be proud of being called a Voltailian? There is a hero in the wrinkled, sardonic Patriarch of unbelief; the women of a frivolous, sceptical age who shed tears or fainted when admitted to his presence were probably less mistaken than the later critics who treated him as a mere buffoon. Lord Morley, with his wonted gravity and eloquence, has admirably defined and emphasised the prophetic side of Voltairism, as he chooses to call it. In spite of all his weaknesses, Voltaire was the Luther of a new reformation, a good and faithful servant of justice and truth.*

Voltaire, the Antichrist, the ambassador plenipotentiary of his Majesty the Devil, was by no means hostile to religion.

* John Morley, Voltaire, 1872, ch. i., Preliminary, 1-42. 


\section{REENCH PROPHETS OF YESTERDAY}

His war-cry: "Ecrasez l'infâme!" was raised, not against Christianity as we understand it, but against its counterfeit and worst enemy, sectarian fanaticism. He was not even the fierce, unrelenting anti-clerical so luridly depicted in Catholic histories. He remained on friendly terms with his old masters, the Jesuit Fathers Tournemine and Porée. He had a sort of half-prankish lingering fondness for the Church. We do not forget his innumerable pamphlets against Biblical miracles. We do not expect St. Voltaire ever to be admitted into the Catholic calendar. Yet his philosophy, on the whole, is surprisingly conservative. Many Protestants, even within the orthodox Churches, would agree with him on most essential points. In England, he might have been a Dean like Swift, or even a Bishop. Was it not rumoured that Madame de Pompadour wanted to bribe him with a Cardinal's hat-a characteristic bit of eighteenth-century gossip?

But if his doctrines were not incompatible with religion, his temperament was. No man could be less of a mystic. His faults and his virtues are alike of the earth earthly, his vanity like his common sense, his warm, active sympathy like his cruel wit. In religious matters he had but two passions, neither ignoble, but both negative: hatred of intolerance and hatred of superstition. His second great weakness lay in his lack of the historical spirit. This was the fault of his times, not his own : not only was he a great historian according to the standard of his century, but he was a path-finder, whose influence is felt to this day. Yet it must be said that to the spirit of impartiality, comprehension, and sympathy in historical studies-the most precious conquest perhaps of our own age, and Germany's noblest contribution to the progress of the human mind-Voltaire was almost a total stranger. Hence the childishness, according to modern ideas, of his Biblical criticism. His stock explanation for miracles was fraud. "The first prophet was the first rogue who met the first fool." In EEdipe, in Mahomet, we find the same keynote : imposture is the foundation of historical religions. As spiritual experience and true historical insight were alike denied him, Voltaire's only guide in philosophy and religion was Reason, but reason narrowed down to common sense, 
to the logic taught in Jesuit colleges and the traditional wisdom of the Parisian bourgeoisie. His constant and most effective method is that of reductio ad absurdum: whatever is contrary to his logic and experience is false. Within its narrow field, Voltaire's reasoning is not seldom unanswerable: and it is almost invariably witty. At the merest touch of his needle-like irony, the fairest bubbles vanish. There is no visible effort: indeed, the result alone tells you that whilst he was smiling with such sprightly grace, a death-thrust has been dealt to some timehallowed superstition. Within these limits Voltairianism may be legitimate: but when logic disproves the obvious, it is thereby committing suicide. And Voltaire was blind to many things which are obvious to men of the twentieth century.

A Voltairian, therefore, is a man in whom common sense is unchecked by mystic intuition, passion, imagination, or by a rigorous historical and scientific training. Applying to revelation, tradition, and dogma his unfailing method of criticism, he cannot but find them absurd, and as ridicule is the best weapon against pretentious absurdities, the Voltairian, witty or not, will naturally be a scoffer. Unable to understand the thoughts and feelings of the religious-minded, he honestly considers them as a pack of superstitious fools, and their leaders as self-seeking hypocrites. For how could educated people sincerely accept what he himself rejects as palpably erroneous? A Voltairian need not be a bad man or a fool: as a rule, he is a decent citizen and a sane, safe, and sensible person. The only trouble with him is hypertrophied common sense. Tear off his sardonic mask, and in the Voltairian you will recognise our old friend the Philistine.

By the middle of the nineteenth century, the identity of the two had become evident. M. Homais, in Flaubert's novel Madame Borary, is the immortal incarnation of middle-class materialism, pomposity, and ignorance masquerading as freethought. Veuillot had already proved that pungent wit was no longer on the side of unbelief, and Pontmartin was justified in saying: "Voltaire has become the idol of dolts: that's his 


\section{FRENCH PROPHETS OF YESTERDAY}

punishment." This alone was sufficient to damn Voltairianism in the eyes of a generation neither profound nor virtuous, but practical and keen-witted. Then, in their terror of the "Red Fiend" stalking abroad in 1848, the Voltairian bourgeois themselves, led by Thiers, Duvergier de Hauranne, Villemain, and other converted liberals, "threw themselves at the feet of the bishops," because they saw the need of a "cassocked police" to help the gendarmes save society. Mérimée, who remained true to his negative principles, Doudan, sanest and most lovable of all Voltairians, Barbey d'Aurevilly and Veuillot, uncompromising and undiplomatic Catholics, poured ridicule on these converts " by the grace of the barricades." But a mightier cause was at work, ruining Voltairian influence in the best minds of the rising generation: the growth of the scientific spirit. For the philosophers of the age of reason, trained in mathematics, astronomy, and the most general aspects of physics, natural laws were simple, universal, eternal : the world was a grand theorem, which is not very different from being a syllogism; fallacies could be detected at once by almost infallible rules. For the nineteenth-century thinker, trained in the historical and natural sciences, the world is a growth and an experiment: our reason, one of its products rather than its law, cannot compass its immensity. Hence new conceptions of complexity, difference, evolution, and a new attitude of prudence, tolelance, sympathy. About the middle of the century the new spirit won the battle, and with Comte, Spencer, Darwin became a philosophy. For these men and their disciples a syllogism proved very little, a witticism nothing at all. Renan, so often called Voltaire's continuator, but who was, in his early career, the somewhat naïve and trenchant apostle of science, expressed the opinion of his generation in his merciless posthumous slashing of Béranger, one of the last genuine Voltairians.

Thus during the first decade of the Empire Voltairianism seemed to be dying fast, and was represented in literature only by a straggling few. Béranger, since the fall of his archenemy Charles X. in 1830, had been living on his glory, which was immense, somewhat burdensome, and, he felt it himself, excessive. He was no hero, but an amiable epicure, a benevo- 
lent egoist, with the semi-innocent duplicity of a man who had to live up to his legend. He was for thirty years the idol of the great army of Philistines. The old lover of Lisette died loyal to his Dieu des Bonnes Gens-a "good little god" who winks at the frolics of grisettes and wine-bibbers. Viennet was a genuine relic of the eighteenth century, an indomitable fossil whose wit was old-fashioned to the point of quaintness, and who allied inexhaustible productivity with pugnacity of the genuine Ferney brand. He lived so long that he was privileged to see a last flickering revival of his doctrines, and his History of the Pontifical Pouer (1866) made him almost popular for the first time in forty years. It was rumoured that on his deathed he was reconciled with the Church. This conversion in extremis created some indignation, not against the enfeebled nonagenarian, but against the priests who thus tried to "confiscate his death." Yet an orthodox end would not have been strictly mvoltairian: there is no scoffing at death, and common sense has not yet fathomed this mystery, the commonest of all. As their creed is mostly negative, holds no promise, allays no fear, many Voltairians accept and even implore, in articulo mortis, the ministration of a Church which they have derided all their lives.

Doudan spent the greater part of his life in the small doctrinaire world of which the Broglie family was the centre: just the cool, equable atmosphere necessary to the perfect development and preservation of his qualities; unspoilt by popular criticism or applause, he was a perfect type of middleclass Voltairianism at its best. Moderation, common sense, equipoise, tolerance, all the neutral and solid qualities of middle-aged men in comfortable circumstances: such was his ideal. In religion he and his friends hated fanaticism like all forms of exaggeration. They honoured the Church within her proper domain, but they measured it out to her very parsimoniously. They were independent Catholics or liberal Protestants, and moderate anti-clericals. These earnest, intelligent men lacked enthusiasm, imagination, prestige ; they were shortsighted, self-centred, self-satisfied; it is impossible to love or admire them very warmly: but they were "infinitely 
respectable." Doudan, kindly, witty, unpretentious, is the best of them all. The gospel of the golden mean, such as we find it preached in his best pages, may fail to satisfy our intensest cravings in critical hours, but it remains far above the daily needs of the average man.

Cousin, the dictator of State philosophy under Louis-Philippe, the Pope of Natural Religion, was revising and toning down his famous book On the True, the Beautiful, and the Good. Sincerely-for he no longer had anything to fear or to hope for in this world-he attempted to propitiate the one great spiritual power, the Church, which, according to him, could stem the flood-tide of materialism. He wanted an alliance between "spiritualistic" philosophy and Christianity, not an abdication of human reason. But nothing short of unconditional surrender would satisfy Rome, which, in spite of all concessions, threatened to place his books on the Index Expurgatorius. Cousin, a unique mixture of the Philistine, the mountebank, and the prophet, spent the last few years of his life dodging the issue, and died uncommitted, but the failure of the Cousinian compromise had long been apparent. In the eyes of all genuine philosophers, the Cousinians, Spiritualists, or Eclecticists were catechists and apologists rather than investigators. For all problems they had a ready-made solution, the one imposed by common sense, rebaptized "impersonal reason."-apparently the kind of reason that does not reason, as M. Faguet remarks. They had some of the qualities and all the faults of orthodox preachers. Cousin himself, his successors Jules Simon and Caro, were excellent orators, for they were not afraid of the commonplace and appealed to a large, uncritical public. They were practical moralists too, and as such they spoke many noble words, useful and uplifting, even when they were trite and redundant. At the same time, a slight suspicion of insincerity could not but attach to their fine phrases. These professed independent thinkers were the prisoners of an orthodoxy. They were a lay clergy of Savoyard Vicars.

Voltairianism was thus dying of inglorious old age, when the victory of the retrograde elements within the Church galvanised it for another twenty years. For Voltairianism, weak on the con- 
structive side, shallow, incomplete though it be, is an mrivalled weapon against certain forms of superstition and ignorance. This Saint-Beuve and Renan themselves conceded. Anti-clericalism inspired a whole literature of pamphlets, novels, and plays. Le Maudit, an anti-Jesuit romance, almost rivalled the success of Sue's Wandering Jew. George Sand's Mademoiselle La Quintinie appeared in the staid Revue des Deux Mondes. The middle-class liberal paper Le Siecle issued a popular edition of Voltaire's complete works. Laronsse's unwieldy Dictionnaire Universel was in spirit as well as in scope the true successor of Diderot's Encyclopédic. The Pope was the chief target of Voltairian satire. Lanfrey, About, Viemnet had their fling at the Pontifical Power. Maurice Lachâtre, "revolutionist and lexicographer, a deist with Voltaire and J. J. Rousseau, a spiritist with Allan Kardec," told in ten ingenuonsly horrific volumes The History of the Popes, relating the Crimes, Murders, Poisonings, Adulteries, and Incests of the Foman Pontiffs, together with the Crimes of Kings, Qucens, and Emperors.

The stage, as in the days of Voltaire, became a pulpit. Eugène Sue, in 1849, had turned his romance The Wandering Jew into an effective melodrama, which in the sixties enjoyed a revival of popular favour. Augier's Fils de Giboyer is a vigorous satire of Catholic society, and, with Aristophanean directness, of its great journalist, Veuillot. Lions and Foxes is another anti-clerical drama, denouneing the machinations of the Jesuits with commendable vigour. Ponsard, the head of the "Common Sense" school of dramatic poetry, gave his dying efforts to a Galileo which was to be the Polyeucte of Rationalism and science. A battle was expected between Catholics and anti-clericals; but the stir soon died out, as the play was crude and unconvincing-the philosophy of Homais translated into psendo-Cornelian lines.

Even the sleepy halls of the Luxembourg rang in their turn with the echoes of the conflict. The first Prince of the Blood, Napoleon (Jérome) Bonaparte, attacked the clerical party in violent speeches which, from such a man and in such an assembly, created great sensation and some scandal. Sainte- 
Beure, his friend, followed his example, and roused even more opposition within the House and more enthusiasm without. Prince Napoleon, "a Cæsar estranged from his class," liked to join a small knot of free-thinking philosophers, scientists, and literary men, either at Magny's, a restaurant of some repute at the time, or at Sainte-Beuve's. One of these agapes, the famous "Good Friday Orgy," kept Parisian tongues wagging for a few weeks. Every year, on Good Friday, small bands of freethinker's, of the shallowest and noisiest description, assemble to a feast of sausages and black-pudding-the coarseness of the fare probably adds a sting to the intended insult. Great was the indignation when the rumour spread abroad that the first Prince of the Blood, possibly a future Emperor of the French, had attended such an anti-clerical feast at the home of a well-known Senator. Sainte-Beuve, sincerely annoyed by this unexpected storm, repeated: "Much ado for an omelet with bacon!" He was slandering his own board; the incriminated meat course was a pheasant with truffles: the Senator was an epicure. Needless to say that neither SainteBeuve nor his guests had any intention of turning a small, strictly private affair into an anti-religious demonstration. The date had been selected without any thought of its liturgical associations. The list of the culprits is instructive : they were Taine, About, Renan, Flaubert, Robin, Prince Napoleon, and Sainte-Beuve himself: a Pleiad hard to match in any time or country.

All these men were branded as Voltairians. The term fits exactly Edmond About, who was even nicknamed "Voltaire's grandchild." Wit, activity, love of luxury and power, an easy bantering style, faith in progress, and no aversion to enlightened despotism : all this the brilliant journalist had in common with the Patriarch; Voltaire's deeper qualities were lacking in his shallow and selfish imitator. Robin, a great physiologist, was a materialist of the rankest type. Flaubert professed no creed but "Art for Art's sake." Renan, Taine, Sainte-Beuve went far beyond mere Voltairianism. Yet, in Sainte-Beuve, under the mask of temporary and not wholly disinterested sympathies for one Church after another, there lurked a permanent element 
not only of indifference, but of hostility to religion. His scoffing scepticism was admirably veiled: we feel its presence all the same.

\section{Spiritual Nihilism: Mérimée.}

In Prosper Mérimée "scoffing scepticism" affects no disguise and suffers no compromise. "He was a great atheist, an outrageous materialist, the personal enemy of Providence; he denied the existence of God, and yet he hated Him as one hates a master." In thus summing up the Credo-or rather the Nego-of his friend H. Beylo (Stendhal), Mérimée was summing up his own. The arch-scoffer of Ferney believed intermittently but sincerely in philosophy, in humanity, in an avenging God. Here we have Voltaire out-Voltaired, destructive scepticism in all its purity, undefiled by any element of affirmation. Mérimée is an extreme, almost a pathological case, perhaps the last of its kind among writers of the first rank, and for that reason he deserves our attention.

When Mérimée was born in 1803, Chateaubriand had recently published his Génie du Christianisme, Bonaparte had signed a Concordat with the Pope: after twelve years of revolution and schism, the nation was fast returning to Catholicism. Yet Mérimée's family was not carried with the tide: the child was never baptized. When, in later life, he would say "We Pagans," he was not using the word metaphorically. In his education, otherwise fairly well balanced, Christianity was totally ignored.

At thirty, Mérimée, who knew Byron's Don Juan by heart, affected the pose of his favomite hero. It must be said in extenuation that about that time the Byronic infection, under many forms - Byronic despair, Byronic rebellion, Byronic dandyism-was pretty general. Mérimée was for a few years a perfumed and heartless cynic. Not for more than two or three years perhaps: but he was to retain through life the fame of a dangerous rake. A certain native coldness of heart, an intense dread of being gulled, a fastidious taste which made gushing and mawkish sentimentality unbearable to him, too intimate an acquaintance with the literature of the eighteenth 


\section{FRENCH PROPHETS OF YESTERDAY}

century, too great an admiration for a slightly conventional ideal of English self-mastery and reserve, a place behind the scenes in the great political comedy of the early thirties, a godless youth, and the friendship of Stendhal: with all these elements in him, all these influences round him, Mérimée could not help being a sceptic, unless he had been a saint.

He was no saint; and for many years he seemed to find in his own infidelity a perpetual source of gratification and pride. As though his Memoir of Henry Beyle were not sufficiently Voltairian in its public form, he had several copies privately printed, with blasphemous and obscene additions, and dated: "The 1854th year of the Nazarene's imposture." And Mérimée was a man of undoubted intelligence, taste, and refinement: but irreligion with him rose almost to the point of a mania.

Mérimée had at least one merit: he was sincere and consistent in his opinions, and did not change them to suit the times. His cynicism, after all, was honest and refreshing compared with Villemain's recent and questionable orthodoxy. He vented his ill-humour about the Pope, the French clergy, the Faubourg Saint-Germain, the whole clerical party, with the greatest freedom in his letters to Panizzi, with more subtle irony in those to his famous "Unknown."

Mérimée affected, under the Empire, to be a man of the world rather than a man of letters. But the rôle he had chosen, or that circumstances had thrust upon him, obliged him to associate constantly and intimately with those very "clericals" whose superstition and fanaticism he so much despised. Everywhere, in society, at the Academy, in the Senate, at Court, he encomntered the enemy. Fate's irony had willed it that the great scoffer should be the friend and protégé of her Most Catholic Majesty the Empress Eugénie. Her mother, the Countess of Teba and Montijo, had been Mérimée's best friend for: twenty years. He had taught his future sovereign, then a little Spanish girl of six or seven, the rudiments of French; he had led her by the hand in the Paris streets, with occasional stops at candy-stores. The Empress always kept her respect 
and affection for "Monsieur Mérimée," as she would persist in calling him, years after his death, when for the whole world he had become "Mérimée." Through her direct influence he was made a Senator, and it was reported that she hailed his appointment with undisguised, even exuberant, delight. On his side, Mérimée was no self-seeking courtier, but, to the end of his life, the independent, respectful, and passionately devoted friend of the Empress. A dying man, ho dragged himself to Paris, and urged Thiers to save the dynasty after the disaster of Sedan. The revolution of the 4th of September, 1870, dealt lim the death-blow. He probably never was a very stanch Bonapartist, but he was, with all his heart, a Eugenist. Now, in the Imperial circle, by the side of the silent, dreamy Emperor, Prince Napoleon represented free-thought, the Empress championed the Catholic Church. The two were openly at odds: thus Mérimée's convictions and his sympathies were at variance. He admired Prince Napoleon and disliked him; even Sainte-Benve he could not wholeheartedly support. He found it impossible to open his mouth in the Senate except on three trivial occasions.

At Court and in society, Mérimée was more in his element than in political life, and retained his freedom of speech. Many attempts were made for his conversion. He received holy medals from ladies of exalted rank, anxious for his salvation. 'To one of these lovely missionaries he expressed his willingness to be baptized, provided she would act as godmother and hold him over the font. Of these attempts, the most constant and systematic was made by Madame de Larochejacquelein: his letters to her, published in 1896, revealed a new Mérimée, an earnest, well-informed, respectful critic; an unbeliever, but no longer a boastful one; a man in whom honest doubt was tinged with regret and melancholy. Such a change does great credit to Mérimée's correspondent, to her sincerity, her intelligence, and her tact. But it is also due to a change in the general atmosphere. The last ten years of Louis-Philippe's reign, the first few of the Empire, had been intensely materialistic : about 1860, on the contrary, the conflict between science and religion was so clearly defined, so intense, that even 


\section{FRENCH PROPHETS OF YESTERDAY}

a careless dilettante like Mérimée could not but feel at times the vanity of mere irony.

Thus we see Mérimée in the guise of a theologian, well versed in scriptural lore, proposing and defending his own interpretation of a Greek word in the Gospel-maintaining his ground with firmness and without pedantry, and although never indulging in an unseemly jest, still a great master of light epistolary style.

"There are," he says, "two different ways of believing. The first is founded on presumption checked by reasoned criticism; the other is based on personal feeling. . . To produce this feeling without appealing to reason is a faculty or a gift which. is not imparted to everybody. I quite understand the words, ' Seek and you shall find,' but I do not think they fit my case at all. If the ordinary rules of historical criticism are applied to religious records, the authenticity of tradition will be even less credible than the account of the early years of Rome given by Livy. Whoever reads the Bible like an ordinary book, without believing in it a priori, will see nothing in it but a very ancient compilation, full of the faults and beauties of Oriental literature. The New Testament, apart from the biographical legend it contains, differs from all ancient books in the admirable morals it teaches, presented by its practical side and addressed to everybody. It is the epitome of the best principles, formerly reserved by the Greek philosophers for a small number of adepts, now placed within the reach of all men without exception. It seems evident to me that there is no better rule of conduct to follow, whatever doubts one may entertain about the origin of the book. . . . It is never easy to form a conviction when one has no faith and merely applies the rules of scientific eriticism. Even in purely material problems, like that of the magnet, our science is soon baffled. Our earth is but a speck in the universe; and yet, shall we ever fathom all its secrets? As for understanding superhuman things, we camnot do it, for that would require a superhuman nature." Thus, under the influence of an earnest Christian, Mérimée's bantering scepticism changed and deepened into pure scientific scepticism, and that honest doubt worth half the creeds. Let us note that this doubt is 
personal, not dogmatic. Mérimée does not say that to affirm without proof, in other words, to believe, is an error and a weakness; it is "a particular disposition of the mind." Not to have this "particular disposition" is not a superiority but an evil, "an evil hopeless in my case." Mérimée at times has almost the wish to believe. "I often think of God and the other world, sometimes with hope, sometimes with doubt. The existence of God seems to me very probable, and I find nothing objectionable in the beginning of the Gospel according to St. John. As for the other world, I cannot help considering it as an invention of our human vanity." *

But he never went beyond a velleity; his critical sense was too strong, his lack of mysticism too radical. If ever he believed he would remain within the limits of orthodox Voltairianism, like his friend Béranger, for instance : he might accept " natural religion," so-called, but on the question of the "positive religions" he would remain uncompromising. Without any provocation, with due gravity, he could not but tell his correspondent that he considered Catholic theology full of Pagan superstitions, the history of the Catholic Church bloodstained, its present policy dangerously narrow and bigoted. He remained " anticlerical " to the last.

Was he ever tempted, as a compromise, to join the Protestant Church? Mérimée's will, dated May 30th, 1869, stated: "I desire that a Lutheran minister be called to my funeral." His desire was respected. The minister, Rev. Napoleon Roussel, in an aggressive speech, claimed the dead man for his Church. This unexpected posthumous conversion, even at that tragic time, created a scandal. Mérimée a Protestant! It seemed almost like a supreme prank of the great mystifier. He had expressed his admiration for St. Paul ; he had confessed that family prayers in a Scottish home moved him deeply. On the other hand, much as he disliked Catholic monks, he declared he loved clergymen even less. They had given him a poor lunch in gorgeous surroundings-unpardonable offence! No man had ever less of the true Protestant spirit than Mérimée. He never was converted, and we must find some other explanation for his strange request.

* Irevue des Deux MIondes, cxxiniv., p. 833. 


\section{FRENCH PROPHETS OF YESTERDAY}

We must repeat that the traditional hold of Catholicism on the French people was still so strong that many avowed Voltairians dared not marry or die without the ceremonies of the Church. "Civil" burials, being comparatively few, attracted great attention, and assumed the significance of an anti-clerical demonstration. Such was the case with Sainte-Beuve's funeral in October, 1869. Mérimée was an Academician, a Senator, a friend of the Empress, as well as a professed unbeliever. He naturally expected that his death would not pass unnoticed; he could hardly foresee the terrible events which were to crowd in the next fifteen months. An anti-clerical demonstration on his grave would easily turn into a manifestation of hostility against the Government he supported, and particularly against the sovereign he loved. He did not wish to be given a posthumous triumph by a party which he hated almost as much as he hated the Church, the revolutionary Democrats, the friends of Raspail, Hugo, Garibaldi. "The Jesuits or the Bousingots?" he once said. The alternative was painful. The only loophole was a nonCatholic religions service, which would give no advantage to either party.

Mérimée was also probably influenced by his desire not to grieve some intimate friends, and especially two elderly English ladies with whom for several years he spent the winter at Cannes, on the Riviera. But, apart from such considerations, he had long before expressed his wish not to depart this earth without some sort of a farewell ceremony. When his friend Mrs. Childe died, he wrote: "There was, I believe, a service in her own home, but no one was invited. That was painful to me. I have on this subject Pagan ideas. Have you ever read Homer? For the Greek heroes it was a great sorrow to die without being mourned for, without being buried. For myself, I would like a ceremony. ..."** Mérimée thus remained a Pagan to the end, even in his Protestant burial. But the young cynic, so proud of his being unbaptized, is far less attractive and human than the old Senator longing for sympathy round his grave.

At his worst, self-satisfied, scoffing doubt; at his best, grave,

* Revue des Derrx Mondes, cxxxiv., p. 12 (1856). 
reasoned, chastened doubt. Shall we find in him nothing but negation? He was a scholar, and believed in the critical method, but it can hardly be said that ho believed in science. He saw its limits too close at hand; he thought that we are but gathering pebbles by the seashore. In science he took no interest except in exact, minute facts. He lacked that power of sympathy and imagination which transmutes versification into poetry, erudition into science, morality into religion. With all his learning, his application, his literary gifts, he was unable to write a real book of history. He had no faith in any political or social movement. He was neither a Royalist nor a Republican, and hardly a Bonapartist. "Man delights me not, nor woman neither," he would repeatedly quote.* He had no great love for his kind. His times seemed particularly mean and stupid to him. This universal contempt was one of his most unpleasant traits. The man who dismisses Victor Hugo with the epithet "fool," and would not have read Salammbo had any other book been at hand, if it were only La Cuisinière Bourgeoise-such a critic may be very learned, clear-sighted, and witty, but his field of vision is singularly narrow.

Mérimée lived withont hope, withont illusion, and yet not without fear. With all his irony and cynical pose, he loved his friends aud his country more dearly than he cared to confess. The regime which he supported, the very society he moved in, the philosophical ideas, the literary forms he preferred, all that imparted to his life some charm or some interest, was threatened with destruction. He foresaw, without dreaming it was so near, the catastrophe which was to overtake his sovercign and his country. So his irony has not the triumphant ring which makes Voltaire's wholesome after all; neither has his scepticism the tolerant, comfortable quality of Montaigne's, who considered "idleness and incuriosity a very soft pillow for a well-made head." There is an anecdote in Voltaire's Correspondence that Mérimée was fond of quoting: "Harlequin was falling from the fifth story of a building. As he went whizzing by, some one on the third floor asked him, 'How do you like it?' ' All right, so far,' he answered, 'if only it would last!' "' A moment's full, then

* Lettres a une Inconnue, ii. 346; Revue des Deux MIondes, cxxxiv., p. 18. 
annihilation: such was Mérimée's conception of life. Without illusions, but elegant and ironical to the last, he continued the race of the noblemen who, in 1793, made epigrams on the steps of the scaffold. His wit has no cheer, his pessimism no grandeur. Despair smirking in Court dress is not an elevating spectacle. He was a spiritual nihilist, but not on the heroic scale-un Ecclésiaste de salon, too keen and too sincere to be despised, but too frivolous to be pitied.

The spirit of Voltaire, as we have attempted to show, offers two aspects. On one side, it means fearless intellectual honesty and militant love of mankind; on the other, common sense as the sole test of everything, and, as a result, scoffing scepticism, spiritual inanity, self-stultification under a thin veneer of wit. Unfortunately for Voltaire, whose heroic services deserved a better reward, it is with this second meaning that the word "Voltairianism" is generally used.

Superstition, intolerance, priestcraft, are great evils in themselves; and against such Voltairianism is a formidable engine of war. But there may be such a thing as too efficient a weapon. We are the poorer by the total destruction of those we combat: the ideal victory consists not in the annihilation, but in the assimilation of one's former foes. Had Voltairianism been able to breathe into the old religion a new spirit of freedom and humanity, or to catch from it some of its moral efficacy and mystic depth, the French Reformation of the eighteenth century would have been as beneficial as the German Reformation of the sixteenth. Unfortunately, the conflict between Catholicism and Voltairianism was not one that could be compromised. The fanaticism of common sense is incompatible with the fanaticism of authority and tradition. Even when we feel that many of Voltaire's victims deserved their fate, we cannot help regretting the undignified method of their overthrow-unworthy alike of their past glory and of their victor's noble purpose. We fear that no doctrine, no ideal, however lofty, could stand the test of this pitiless and irrefutable criticism. Whatever may have been the intentions of its chief exponent, Voltairianism has 
proved indiscriminately destructive. The soul that has once accepted it is not only laid waste, but for ever embittered, sullied, and shrunken. Fortunately men are seldom consistent in their attitude of mind ; for unchecked Voltairianism, starting imocently enough with the praise of common sense, leads nowhither but to the universal and incurable cynicism of Mérimée. 


\section{CHAPTER II}

\section{ROMANTIC HUMANITARIANISM}

1. Formation of Romantic Humanitarianism (before 1848).

Romantrcisir, as a recognised school in French literature, died in the early forties, after two decades of splendour. At the moment when its leaders were at last reaping academic honours, the movement seemed to be struck with barrenness. The authors seemed exhausted; the public was indifferent or hostile. Rachel revived the popularity of classical tragedy. Ponsard's Lucrèce triumphed within a few weeks of the failure of Hugo's last drama for the stage, Les Burgraves. And when Célestin Nanteuil was asked for three hundred young men to defend the unpopular masterpiece as Hernani had been defended, he had to reply, with a melancholy shake of his long locks: "Tell your master that there are no young men any more."

The Romantic school was dead, but not the Romantic spirit. Only it had found a new channel-politics. Lamartine was the moral leader of the opposition to the July monarchy. Hugo was a member of the House of Peers, with opinions still uncertain, but, whether in the form of Bonapartism or of Orleanism, leaning towards democracy. Quinet and Michelet, abandoning pure history, had turned their professorial chairs at the College de France into democratic and anti-clerical tribunes. George Sand alternated socialist romances with her sweet tales of peasant life in Berry. Vigny's solitary thought was, on a different plane, undergoing the same evolution. Musset almost alone was not affected by this transformation, this rejuvenation of Romanticism. 
A radical transformation indeed: not a few Romanticists burnt what they had worshipped. Legitimist in 1822, Romanticism was democratic in 1848. Its aristocratic individualism had changed to Socialism in the widest sense. Its love for the Middle Ages had turned to hostility ; its Catholicism was replaced by a vaguely pantheistic humanitarianism. Yet under these contradictory manifestations the same spirit prevailed, unmistakably.

What is the spirit of Romanticism? Is it a disease, as some of its earliest opponents roundly said nearly a century ago, and M. Lasserre but yesterday? Is it decadence, as M. Nisard beliered to his dying day, or the Commune, as Thiers, the archPhilistine, told Remusat at the time of the great insurrection? Is it Christianity opposed to Paganism, the dreamy and melancholy North opposed to the lively and clear-thinking South, spontaneity and raciness opposed to the elaborate imitation of ancient models? Is it Mediævalism-a new Renaissance-a return to Nature-the combination of extremes $-a$ fondness for the abnormal-Catholicism-Protestantism-a reaction against the Revolution-the continuation of the Revolution-" liberalism in literature"? Is it simply, in Hugo's own words, "everything within ererything"? Of such definitions there is no end. But Romanticism is a historical movement, and the safest way of describing it is to compare and contrast it with what preceded and followed.

What the Romanticists objected to in Classicism was the excess of abstraction and generality, the lack of a personal and spontaneous element. To the Romanticists, their successorsthe Parnassians in poetry, the Realists in the novel and the drama-reproached their lack of self-restraint and objectivo calm, their passionate individualism, which made all their works the revelation and glorification of Self. The inspiration of the Romantic movement was subjective; it spurned the objective checks of tradition, common sense, or scientific prudence. And this led naturally to the supremacy of imagination in the intellectual world, of instinct in the moral, of mysticism in the spiritual.

"A hypertrophy of the Ego," such was French Romanticism 
from the first, in its ancestor Rousseau as well as in its earliest complete exponent, Chateaubriand. Hence the exalted pride common to all these men, so striking even in the sanest and most reserved of them all, Vigny. Hence their spiritual isolation from the rest of a world which they despised; hence their melancholy, born of that aloofness, cultivated as a sentimental treasure and as a new proof of their superiority. In politics and in religion, Royalism and Catholicism were but the gorgeous cloaks of their aristocratic anarchism. In order to arrive at a comprehensive definition of what is known in history as the spirit of 1848, and which we take to be Romanticism applied to politics and religion, we must endeavour to explain by what inner development, and under what influences, Romanticism passed from its first attitude of individualism, pessimism, and conservation to its later attitude of humanitarianism, optimism, and progress. *

In such a change, the mere influence of age is undeniable: anarchism is a youthful dream, from which reality awakens us. But if the lapse of years explains the wane of Romanticism, it does not explain its transformation. We understand how a shaggy poet of 1830 , loud in his declarations of universal revolt and hurling defiance at mankind in general, might turn into a sober and peaceable citizen and crop his mane into decency before it be streaked with grey. But the change in the leading Romanticists did not imply any cooling off; most of them were as ardently enthusiastic-although in another cause-in 1848 as in 1830. Their temperament remained the same.

Perhaps the opposition between their two successive doctrines is not so radical as it appears at first. The germ of latter-day

* Many passages in this chapter will perhaps seem to be out of place in a study of religious thought, as they refer chiefly to social doctrines and events. It must be borne in mind that the decline of Catholicism throughout the eighteenth and part of the nineteenth centuries had "released," to use a chemical term, a vast amount of religious feeling which, seeking a support, combined with political and social aspirations. Romantic Democracy not only had its religious side, but it was in itself a religion, and a substitute for the traditional Churches. On the other hand, the apparent recrudescence of Catholicism was greatly due to political causes. There is more Christianity as the term is generally understood in this country, in the free-thinking Socialism of G. Sand than in the orthodoxy of Mgr. Dupanloup. (Cf. her letters to Mazzini and Louis Napoleon, Corr., iii.) 
democratic humanitarianism is found in the most individualistic and aristocratic works of the earlier period. Vigny's Moses is alone in his glory, proud and melancholy, but he is a leader of the people. The Black Doctor's advice to Stello is "Alone and free, to accomplish one's mission." The notion of leadership, of a mission, implies an altruistic, a social element.

How could thoroughgoing individualists imagine that they had a mission? If they delighted in the spontaneous, the original, the unique, what could they teach, and whither could they lead? Subjectivity and relativity are as a rule so closely linked together that we can hardly dissociate them in our minds : personal inspiration is only of personal value. Yet for the Romanticists the first term did not imply the second. They scorned objective limitations, authorities, methods; they wanted to follow naught but the dictates of their own hearts; they craved for singularity, and not seldom songht the abnormal; they had a keen sense, which the psendo-classicists lacked, of life's complexity, at least of the varieties of its external manifestations. They ought naturally to have come to the conclusion that truth was relative. But, on the contrary, they did not doubt that they could reach, in their independent way, conclusions of universal value. Influenced by the Catholic tradition, by classical rationalism and its belief in natural laws, they took it for granted that the poet's subjective inspiration was of objective import. The poet sees intuitively what others, later, demonstrate scientifically. He is a seer, a prophet, and therefore a leader-a leader of thought, and through thought a leader of men.

Thus the French Romanticists considered themselves as the priests of the Ideal. Such a pretension may seem extravagant; yet it gave strength and purpose to their lives, and saved them from mere Byronic despair. They thought they conld move the world: such faith was not so absurd then as it may appear to some modern crities. The glorification of Roussean and Voltaire at the end of the eighteenth century was still in everybody's memory: here were two men, of mediocre, or even humble, origin, who, by the sheer power of their genius, were supposed to have shaken the most ancient monarchy in Europe, 
and Christianity itself. The harm these evil prophets had done, could not other prophets repair? Was not Chateaubriand the co-restorer of the Church and a king-maker? The formidable shock of the French Revolution, the fabulous rise of Napoleon, led men to believe that their wildest dreams might come true. Thus French Romanticism, the cult of the Ego, far from avoiding the burning problems of the times, asserted itself as a militant influence. Subjective in its inspiration, it became social in its manifestations. Needless to say that the mission of the poets rested on an illusion. The leaders were led, the prophets were echoes, and the revelation they found in their hearts had been imparted long before to politicians and journalists. But the illusion as a rule was sincere, so sincere that it could stand the shock of repeated conversions on the part of the prophets. Whatever they believed, they believed intensely; they ascended more than one Sinai, returning with several conflicting Laws: but their faith in their inspiration remained unshaken.

It is true that with all their early affectation of aloofness they loved popularity, and their desire for applanse facilitated, if it did not determine, some of their changes. But this is only a small aspect of the truth: on the whole, these men were not flatterer's and time-servers. Especially under the Second Empire, their independence is beyond doubt: all of them were in opposition-an opposition not merely to a regime, but to a clearly expressed and overwhelming verdict of public opinion; some of them spent eighteen years in exile. In the choice of a creed-political or religious-they were guided neither by reason nor by interest, but by imagination and sentiment.

And this leads us to a graver charge against the Romanticists as leaders of thought: sentiment, especially in authors, will casily turn to sentimentalism. When emotion is enjoyed for its own sake, life becomes a sort of comedy, half-consciously played by the poet for the world and for himself. This element was strong in Chateaubriand, at all stages of his career, and in all his brood after him. We may fully recognise the justice and strength of this accusation without dismissing Romantic thought as deficient in seriousness. Even in the case of the worst 
offender in that line, Chateaubriand, there was earnestness mingled with his make-believe. The Romanticists chose a creed because of the feelings it aroused in them, and these feelings they enjoyed to the full: but their emotions were genuine all the same, and, as a rule, noble and inspiring. For these poets, a gush of sentiment was a reason; common sense and justice must yield to sympathy, admiration, pity; love is a law unto itself ; faith is justified by its own fervour: all this is delusive and dangerous, no doubt; yet it has ever been the foundation of faith. And unless one accept a historical revelation, the only alternative to emotional religion is Voltairianism.

At first, Legitimism linked with Catholicism appealed to the Romanticists. No wonder: Revolution and Empire were still discredited by their excesses and failure; the only other choice was shallow Liberalism, coupled with shallower Voltairianism, and expressed in insipid pseudo-classical literature. Compared with these mummies of an enlightened age, reaction had the freshness of youth combined with the majesty of centuries. It opened a splendid backward vista, and called forth loyalty, heroism, all the knightly virtues. Soon, however, our noble poets realised that Louis XVIII. was not St. Louis, nor Charles X. Charlemagne. Their imagination had carried them back to fanciful medirval times; but the restored sovereigns were men of the eighteenth century, who had learnt nothing and forgotten nothing. Old, unheroic lings, who had never fought for their own canse, nor even encouraged their champions; a Constitution imported from England; a humiliating peace, unbroken save by the inglorious war in Spain: this was enough to breed disenchantment. There are already signs of such a feeling in Vigny's Trappiste (1822) and in his Cinq-Mars (1826). Chateaubriand himself, before the Revolution of 1830 , had lost faith in the Government of his own making. Tho restoration was but the shadow of the old regime, and that regime itself, with its centralisation and its army of middleclass officials, had little in common with the feudalism of their dreams.

It must be borne in mind that Catholicism seemed indissolubly 


\section{FRENCH PROPHETS OF YESTERDAY}

linked with legitimism; that the Romanticists had come to their religious faith at the same time and for the same reasons as to their political allegiance; and that their gradual estrangement from the old Church was parallel with their estrangement from the old monarchy. The Revolution of 1830 helped them to realise the change which had taken place in their hearts. For another decade, their imagination will linger fondly on mediæval lore: but they are more and more absorbed in thoughts of the present. They are still lovers of the past; they no longer are what Ballanche called de Maistre, "prophets of the past."

Had democracy triumphed in 1830, instead of being kept back for eighteen years by the Orleanist compromise, the Romanticists would probably have combated it. They had a clear' notion of the people's power ; they had no great faith as yet in the people's ability to use their power aright. "Vox populi, vox Dei " was not yet their cardinal dogma. In Hernani, Victor Hugo spoke eloquently of the people as "an ocean-dark, unfathomable, uncontrollable," with religions dread rather than with confidence and love. In Stello, Vigny condemned democracy as well as monarchy, absolute or constitutional. Three lines of thought led them from this state of indifference to one of active sympathy: patriotism, the rise of the social problem, the free Christianity of Lamennais.

The national feeling is by no means exclusively democratic: it was strong among the Romanticists before the Revolution of 1830. But it happened that in France the Bourbons were held to be the creatures and the tools of the Holy Alliance, whilst Louis-Philippe adhered consistently to his policy of nonintervention and peace at any price. Monarchy thus seemed to mean national abasement, whilst the Republic and the Empire stood for glory and the natural frontiers. This patriotic spirit had not the brutality and the selfishness of Chauvinism or Jingoism: it had a higher ideal than national aggrandisement. With undeniable good faith, the French made a distinction between their own victories, their own conquests, which were the triumph of civilisation and progress, and the victories of the Allies-the triumph of reaction. This was not wholly an illusion; or if it was, it was shared by the liberal element 
among their very enemies. Their patriotism, although aggressive, was ennobled by its connections with the universal principles of 1789 . If war was desired, it was as a crusade, and annexation to France was thought to mean redemption from tyranny. All oppressed nations struggling for their independence had the warmest sympathy of the French patriots-Greece first of all, from 1820 to 1830; then Belgium, Ireland, Italy; later Hungary, and especially Poland. Russia and Austria were at the same time the representatives of conservatism in Europe and the worst oppressors of suffering nationalities: thus the two conceptions of liberty-national freedom from a foreign yoke, political freedom from an autocratic government-became more and more closely associated. Patriotism, democracy, international brotherhood were united in a generous and mystic synthesis.

The second element in Romantic Humanitarianism was Socialism in its widest sense, a feeling of love and pity for the most numerous and poorest class, a desire to help them out of their ignorance and misery. The social problem, such as we understand it, was practically unknown in France before 1830 . Its rise was due to changing economic conditions, to the first developments of modern industry and capitalism, and to the growth of the democratic spirit. The crisis which attended the Revolution of 1830 caused the first labour insurrection at Lyons, with its threatening motto: "To live working or to die fighting." This created a deep impression. France became aware of the presence within her borders of a class, a whole people, driven to despair by economic oppression. The sympathy which the Romanticists extended so freely to all victims and to all rebels, whether individuals, classes, or nations, never was enlisted in a worthier cause. Here were apparent injustice and undeserved suffering; love and help were needed. Hearts were mored, imaginations set on fire. 'The explanations offered by political economists seemed sordid and cruelly insufficient. On the contrary, the Saint-Simonians, with their strange mixture of industrialism, mysticism, and fraternity, appealed to them; even Fourier, obscure and childish though he is, had his share of influence. As for Leroux and Reynaud, they were so closely 
connected with Romanticism that no serious history of the movement can afford to ignore them. Yet, interested as they were in social problems, the Romanticists did not unreservedly accept the vague, Utopian schemes propounded in their days under the name of Socialism. Lamennais and Lamartine even denounced the whole system as too materialistic. Their sympathy with the tendency remained imaginative and sentimental.

A third element in the religion of the Romanticists was the Christian tradition. All of them lost their faith in Catholicism in the first few years of Louis-Philippe's reign.* Yet with their mystic and sentimental tendencies they could not return to the cold, unimaginative materialism of the eighteenth century nor be satisfied with the Hegelianised Voltairianism of the Eclecticists. Christian traditions and dogmas had become legends, myths, or symbols to them, but their imagination remained deeply Christian. Lamennais, for many years a priest and a power in the Church, with the spirituality of a Breton and the sombre violence of a revolutionist, wrote his Words of a Believer immediately after his condemnation; in this wonderful and inspired pastiche $t$ he struck the note which all Romanticists were more or less to re-echo. Like a Hebrew prophet, he denounced the oppressors of the people, the kings, the priests, the callous rich. $\mathrm{He}$ clothed democracy and free-thought in the magnificence and earnestness of Biblical language.

Not the style alone was Christian: the teachings of Jesus, freely interpreted, freely applied to contemporary problems, were still the dominant influence : a spirit of love, even in its denunciations; of faith, even in the hours of suffering. Jesus was no longer the theological entity worshipped according to rites, in churches of wood and stone, by salaried priests-but the Master, the Friend of the poor, the Lover of justice, the Redresser of wrongs-and, in boldly modern terms, the King of democrats, the Messiah of Humanitarianism.

But the other Democrats and Romanticists had not been

* Cf. Musset's “Je ne crois plus, ô Christ! en ta parole sainte"; Vigny, Journal d'un Poëte.

$\dagger$ The application of Apocalyptic style to modern problems was already strikingly exemplified in Vigny's Paris (1831). 
so thoronghly Christianised as Lamennais; while adopting his language, they gave it a more symbolical value. $L$ In their struggle against the Church, the Humanitarians fought side by side with men very different from themselves, but even more anti-clerical, the Voltairians and tho Eclecticists. Withont adopting their scoffing attitude, or their shallow and heterogeneous philosophy, they conld not but feel their influence. Without becoming anti-Christians, they extended the notions of inspiration and Messimism, hitherto the monopoly of the Christian tradition, to all the great and good men who were "the Fathers of human thought." And, reverting perhaps to the Jewish conception of a chosen people, or continuing the Catbolic tradition still accepted by de Maistre-Gesta Dei per Francos-they applied to France many of the Messianic attributes, as the Christians had applied to Jesus the passiges referring to the ideal Israel in the prophets. France had a mission, a gospel, the "Rights of Man," through which she would redeem the world. She was "a Christ among nations," and Paris was the new Jerusalem. $\dagger$ Thus were patriotism, democracy, and the Christian ideal of brotherhood, service, and sacrifice combined into one faith.

But patriotism, the love and service of France as the modern Messiah, was not a final term: the success of the nissionall nations delivered through the Rights of Man-implied the absorption of the deliverer herself into the rest of the enfranchised family. Universal brotherhood was the end. Then the whole of mankind, equal and free, would be conscions of its Dirine essence: for the Incarnate Word of God, figured eminently in Christ Jesus and other Messiahs, yet is no individual man, race, or nation, but the collective Being of whom all are members, Humanity. +

The humanitarian faith therefore stood for the mity of the race: within the nation (liberty, equality, fraternity

* E.g., in 1841: Cousin, Villemain, Libri, Génin, the Constitutionnel on the one hand; Lamennais, George Sand, Michelet, Quinet on the other.

† Is stated before, these ideas wero aecepted by a number of foreigners, even for a while by the great mocker, Heine. Cf. Englische Frugmente.

† Cf. Lamartine, Ode à M. de Genoude, Irecuillements: "Le Verbe est fait humanite" -almost a metaphysical pun. 
among citizens) ; throughout the world (liberty, equality, fraternity among nations); and throughout all generations (mystic oneness of Humanity). It also stood for Reason, by which was meant the growing consciousness of the collective Mind; and for Progress: Mankind as one Being was like an immortal man learning and advancing in spite of obstacles and partial defeats. But Reason and Progress as understood by the Romanticists were very different indeed from what the Voltairians meant by the same terms, i.e. "common sense" and material improvements. These notions of reason, liberty, and progress were not seldom curiously combined with lingering traces of the earlier conceptions-mysticism, authority, and the Fall.

Humanitarianism was the main element in the religion of the Romanticists. Another, secondary but not negligible, was Nature-worship. When they were still individualists and Christians, the poets saw in Nature either an extension of their personality, a mirror or a foil for their changing moods, or "the handiwork of God declaring His glory." As their" spirit became more social and less theistic, they considered Nature as one of the manifestations of Universal Life and its substratum, and therefore as a revelation of God rather than as a creation distinct from Himself. Under Hegelian influences - direct in the case of Quinet, through Cousin for the othersthey reached the conception of " a God triune, at the same time God, Nature, and Humanity." The development of Romanticism in the direction of pantheistic naturalism is much more clearly marked after than before 1848 .

Such was, in its outlines, the religion of the great Romanticists in the closing years of Louis-Philippe's reign. We need hardly say that it never was formulated as a hard and fast system.* As a metaphysical effort, it was as vague and contradictory as all genuine religions. We are aware, not only of the differences among Romanticists, but of the incessant variations of any one writer, torn between individualism and Socialism, between the Fall and progress, between mysticism and reason, between orthodoxy and free-thought, between the

* Best in Leroux, De l'Humanité, 1840; George Sand, Spiridion, 1839. 
old and the new. Yet the general tendency is unmistakable: the attitude of Lamennais, Lamartine, Hugo, Vigny, George Sand, Michelet, Quinet, on the one hand, and the SaintSimonians, Leroux, Reynaud, even Proudhon, even Cabet, on the other, is the same. It had all the elements of a religion -faith, hope, and charity. To the outsider, we should say the unbeliever, like Thackeray,* it offered a monstrous combination of silly Jingoism, demagogy, sentimentalism, with a blasphemous transposition of Christian symbols: but scoffing scepticism provides the surest means of misunderstanding a generous movement. To innumerable young men, a noble generation, the last of whom are still with us, it was a living faith, with its dreams of beauty, its call to heroism, unselfishness, and, if need be, martyrdom.

\section{Michelet.}

February, 1848, saw the triumph of Romantic Humanitarianism: for a few weeks the whole people seemed in tune with the great poet, Lamartine, who, by the sheer prestige of his generous eloquence, had become their leader. The inexperience of the new rulers, the impatience of turbulent democrats like Barbès and Blanqui, the immature schemes of innumerable Utopian socialists-Considérant, Cabet, Leroux, Proudhon, Louis Blane, an economic crisis raging all over Europe, the hostile attitude of the provinces, which had accepted the Parisian revolution with sullen diffidence-all this dispelled the dream of an immediate millennium. A terrible socialistic insurrection, still fresh in the popular mind as "the Days of June," was suppressed by Cavaignac with the brutal energy of a soldier trained in Algerian campaigns. Society trembled retrospectively and clamoured for a saviour. Idealism was doomed. In December, 1848, Louis-Napoleon was elected President of the Republic; in December, 1851, he made himself Dictator; in December, 1852, he was crowned Emperor of the French.

Now Louis-Napoleon was himself a Romautic Humanitarian,

\section{- Paris Sketch Book.}


a dreamer, a socialist, the champion of oppressed nationalities, and a Crsarean democrat: perhaps he saved more of the ideal of 1848 than any other regime, and especially a conservative Republic, could have done. But this was not realised at the time. Napoleon was the elect of the Conservatives; his Coup d'Etat was an act of violence and fraud; Republican leaders were imprisoned or exiled; a craving for wealth and luxury became the ruling passion of French society. Thus all those who had hailed with joy the pure dawn of the Second Republic considered themselves, under the Second Empire, as defeated, disowned, spiritually exiled. Lamennais, in some respect the master of them all, a prophet twice fallen, spent the short remainder of his life in obscurity, until that cold and misty day in March, 1854, when, amid an immense and sombre crowd, between threatening lines of soldiers, his body was carried, unchurched, to the nameless grave of the poor. Lamartine dragged his chain until 1869. Infinitely sad was the long martyrdom of this man-the growing solitude, the jeers or the indifference of the new generation, the drudgery, the sordid daily battle with poverty. Never was "Væ Victis!" repeated with more pitiless insistence. George Sand, too, suffered deeply: but she issued from the ordeal chastened, yet unconquered. Her faith turned into a strong, quiet, patient meliorism, unshaken by the spectacle or the prospect of temporary reactions, no longer made feverish by the hope of a new heaven and a new earth close at hand. And in the uneventful tenor of her life after the storms of her romantic career were over, her gentle personality revealed itself in all its beauty-with her modesty, her simplicity, the sanity of her mind, the kindness of her heart, and that peace which is a reward and a lesson. Quinet, like George Sand, grew inwardly as a result of his party's defeat: his vague humanitarianism deepened into an almost puritanical religion of conscience. We should like to dwell on the trials of these noble souls, who, in spite of many weaknesses, were faitliful servants of the ideal; we should like to linger a while with their friends, often their inspirers, Jean Reynaud and his Earth and Heaven, Leroux and his Beach of Samarez, Barrault and his Christ, 
Enfantin and his Eternal Life, and, among the younger generation, Eugène Pelletan. But the evolution of Romantic Humanitarianism will be clear enough if we limit our study to the greatest representatives of the school, Michelet and Victor Hugo.

The names of Quinet and Michelet are inseparable. The two men were united by fifty years of "heroic friendship." Their starting-point was the same: in 1827 Quinet translated Herder and Michelet Vico, and these philosophies of history permanently influenced their thought, gave them their living faith in human progress. Both were ardent democrats, both freethinking mystics. In the name of progress, democracy, free-thought, and religion, both declared war on Roman Catholicism, turned the old Collège de France into a church of the new Reformation, and published jointly their lessons on-or against-The Jesuits (1843). Both were deprived of their professorships by the Napoleonic reaction, and the present Republic honours them both, with Victor Hugo, as its prophets, its sponsors, and its spiritual leaders.

We have already studied Edgar Quinet, the Huguenot without a creed. No school, no Church can claim the mobile, ardent, and tender soul of Michelet. He ignored or despised abstractions, formulie, dogmas: he was all life and love. "Other" [historians]," he said, "were more brilliant, more judicious, more profound: I loved more." Individuals, nations, nature, were alike alive to him. They lived again in him; his soul would thrill at the recital of their sufferings or of their happiness; he lived again in them: he lent them his passions, his aspirations. Every one of his books was a "resurrection," or an interpretation, of life. Of every one could be said what he wrote on the front page of The People: "This is myself."

Thus Michelet, perhaps the most subjective of all Romanticists, was at the same time the least egotistic. His personality was ever present, but ever in the form of unselfish sympathy. He was not infected with Chateanbriand's melancholy, because he knew neither the gloom of moral isolation nor, like Vigny, "the burden of greatness." Fully conscious of his own powers, free from shrinking self-difldence, 


\section{FRENCH PROPHETS OF YESTERDAY}

he was yet, like George Sand, without pretence and without vanity. This simplicity of heart, a rare virtue among writers in our sophisticated age, saved him from the first danger that menaces whoever bases his philosophy on love: sentimentalism. So sincere was he, so true of soul, that in his thousand pages of lyric effusions there are many which are bizarre, excessive, disconcerting, even ridiculous; there is not one that is downright mawkish and unmanly.

The second danger which threatens too loving a soul is quietism, repose in God, a kind of mystic optimism that kills energy. Michelet was born in poverty, and rose in life through superhuman efforts on his parents' part and on his own. $\mathrm{He}$ was a son of the Revolution and saw the Great Empire.* Thus his own experience and that of his country taught him to believe in the necessity and the virtue of effort. The first characteristic of religion, in his mind, was that faith which prompts to action. "Will and Power are one. Whoever wills, strongly, continuously, and in spite of everything, conquers every obstacle." $\dagger$ His religion was not contemplative, beatific, but militant.

Love has a third danger: its arbitrariness. Love is bound by no law ; it effaces the distinction between good and evil; it ruins justice. Romanticism, at a certain period of its development, seemed disposed to sacrifice everything to the rights of passion: now, for Michelet, the ideals of justice and love were inseparable. Justice was the supreme crown of love, and love the flower of justice. In this puzzling, incomplete world of ours, apparent conflicts between the two are not impossible: in such a case, Michelet would unhesitatingly take the side of justice. If he adınired the Revolution it was for its " profoundly pacific, kindly, humane spirit," no doubt, $\ddagger$ but chiefly because it was the "advent of law, the resurrection of Right, the reaction of Justice." $\$$ The same criterion will be applied to Christianity: "[The question is] to know whether the dogma of Grace and Salvation through Christ, the only basis of Christianity, can be reconciled with Justice; to know whether this dogma is just, and will stand." And as Reason is but the way to Truth, and Justice

* Born 1798. $\ddagger$ Révolution, Preface, 1847. § Ibid., i. 1 .

† Une Année au College de France, 506. 
but Truth in action, Michelet worshipped " at the altar of Right and Truth and eternal Reason, which has ... not lost one stone." * "Identical in all ages, on the firm foundation of Nature and history, Eternal Justice shines." +

The religion, not of love alone, but of justice and truth in the spirit of love, and of activity for the sake of justice, such was Michelet's filith. The centre, the foundation of it was $l c$ foyer, the hearth, a sacred and tender word which "home "does not fully render. "The hearth is the stone upon which the City is builded." + It must be pure, anstere, united: war to any system or individual that wonld attempt to divide or weaken it! There the first lessons of work and sacrifice must be learnt; there must reign harmonionsly the two principles, justice and love, embodied in the father and the mother. Michelet was a man of the people, like Veuillot and Prondhon : it is significant that all three, so radically different in many other respects, had the same uncompromising devotion to the family altar. This devotion is evident everywhere in Michelet's life and writings. It was the origin, it remains the saving grace, of his strange books $L$ 'Amour (Love), La Femme (Woman), so often condemned equally by Gallic levity and Saxon prudishness. It was the basis of his treatise on education, Nos Fils (Our Sons). On the sanctity of marriage, the integrity of the home, the Catholic journalist, the socialist polemist, the Romantic historian were as intractable as any old Roman or any Puritan.

The city is but a larger family, whose service requires the same virtues. First of all it must be united, not by outward compulsion, but in the bonds of love. And France in the nineteenth century was not united. "Our boasted unity," said Michelet, "is superficial. The cultured few and the illiterate populace have little in common." To bridge the chasm between the classes and the masses was Michelet's constant preoccupation. Himself born among the poor, he knew them well, and loved them, for their patience under hardships which he had shared to the full, and for their pure ideal of brotherly assistance. To his students, sons of the bourgeoisie, he preached the duty of going

- Revolution, Profaco, 1868, 11. † Bible de l'Humanite, 385. 


\section{FRENCH PROPHETS OF YESTERDAY}

to the people, simply, fraternally. He felt that even the best intentioned writers-himself as well as the rest--had left the people spiritually unfed and unclothed. As the highest function of the "foyer" is to educate the child, the highest function of the State is to educate the people. "What is the first part of politics? Education. And the second? Education. And the third? Education." Just because he was himself of humble origin, his aspirations for the social betterment of the lower classes were sane, moderate, and at the same time idealistic: it is bourgeois politicians, not the working men themselves, who formulate in the name of the people Utopian demands. Michelet was not blind to the present limitations of the poor, and he knew that it was not bread alone they were craving for, but truth, justice, and love.**

The home of this immense family is France: patriotism is with Michelet as with the Ancients an essential part of religion. He loved France passionately, in the harmonious diversity of her provinces, in her tragic and glorious past, in her generous aspirations, in her living personality. In him the historian, the patriot, and the prophet were inseparable. On the question of patriotism, as on that of the family, he accepted no compromise. "Another religion," he said, "the humanitarian dream of philosophy, which believes that it can save the individual by destroying the citizen, by denying the right of the Nation, by denouncing the Fatherland, that other religion, too, I have sacrificed. The Fatherland, my Fatherland, alone can save the world."

Yet, ardent patriot though he was, and opposed to internationalism, Michelet was not indifferent to other countries. $\mathrm{He}$ hailed, in 1848, " the eagle of Poland, which has so often bled for us, the tricolour of Italy-Italia mater-the red, black, and gold of Germany, my beloved Germany." All nations are persons, like France, sisters to be respected, and helped, and loved. All will sit some day at the universal banquet of peace. It is true he hated England as much as he loved Germany: he shared the popular prejudices of the men of his generation, who could not forget Waterloo and St. Helena; England represented in his eyes materialistic strength and national selfishness. On the

* Cr. passim, Le Peuple, 1846; Une Annee au Collige de Fr'ance, 1847-8. 
whole he was, like Hugo, Qninet, Lamartine, a humanitarian patriot.

"My country alone can save the world." Michelet believed in the mission of France. "For the last two centuries, one may say that the true Pope was France; authority lies here, under one form or another; here is the centre of Europe, through Louis XIV., Montesquien, Voltaire, and Roussean, through the Constituent Assembly, the Code and Napoleon; all other nations are eccentric." France in the eighteenth ontury formulated the creed of the modern world, and the Revolution undertook its practical application.

In the worship of the Revolution, all the tendencies of Michelet's thought united-love and justice, patriotism and humanitarianism. The Revolution was for him the incarnation of the French spirit: "Frunce and Revolution are henceforth synonymous." It was truly a religion: it had all the characters of one. "The Revolution, some one said [Quinet?] ought to have placed itself under the banner of Luther or Calvin. I answer : this wonld have been an abdication. The Revolution adopted no Church. Why? Because it was itself a church." * "It created the faith that accomplishes miracles, or rather for which there are no miracles, so simple do the most superhuman tasks appear. As agape, as communion, nothing in this world was ever comparable to the enthusiasm of the federations in 1790 . Sacrifice in its absolute, its infinite grandeur, the surrender of self without holding back anything, was seen in its most sublime form in the enthusiasm of 1792 : a sacred war on behalf of peace, and for the freedom of the world." + Whenever Michelet spoke of the Revolution, it was in tones of fervonr and awe: "What am I," he said, with the mystic self-abasement of a monk before the Cross, "what am I that I should be allowed to relate these scenes?" The Revolution is divine, nay, it is God: "... Justice, the new God, whose war-name here below is the Revolution." † The book which contains these words appeared in 1869, after twenty years of materialistic and sceptical reaction had taught France to jeer at her own past; Michelet

- Révolution, Preface, 11. † Ibid., Preface, 11-12.

Nos Fils, 294. 
had spent seven years in a close study of his idol, yet his faith was unshaken.

The family; the people; the nation, France; mankind, as the great family of families; the Revolution, as the highest expression of France and mankind in the service of justice and truth : such were the objects of Michelet's adoration. To this list, should we add Nature? During the Second Empire, the great historian ventured into a new field, and wrote his delightful medleys of science, poetry, sentiment, fantasy, The Bird (1856), The Insect (1857), The Sea (1861), The Mountain (1868). Sick, body and soul, after the triumph of reaction; deprived of his professorship, of that contact with young men which had always been such an inspiration to him; exhausted by his great effort in writing the history of the Revolution, he sought peace, oblivion, and fresh courage in the heart of nature. He was no doubt influenced also by the immense progress of natural sciences in the middle of the century. But Michelet was not strictly a nature-worshipper, a naturalistic pantheist. What strikes him most in nature is neither the spectacle of its beauty, as in the case of the other Romanticists, nor the idea of inflexible law, as with the Positivists. Natural history, like human history, was for him a "psychomachy," a drama of souls. His anthropomorphic imagination saw the love, the struggles, the sufferings of animals, and perhaps even of the elements. He insisted on the relations of nature to man - the possibility of a state of harmony rather than of war between the higher and the lower creation, the usefulness of our humble friends and fellow-workers, birds and insects, of our great doctors, mountain and sea. These books of the new St. Francis, full of delicate observations and accurate descriptions, are yet, first of all, sermons and lyrical poems. Michelet remained even in his nature studies the apostle of effort and love.

Beyond and within nature and mankind, God; God, as the supreme realisation of justice and love, "the universal soul of the worlds, who is but Truth and Justice, impartial and immutable Love." * Michelet was no metaphysician and no

* Bible de l'Humanité, 387. 
theologian. Philosophers are not certain whether his conception of God as both immanent and transeendent should be called spiritualism or pantheism. Let them dispute: his God was the living God, and a loving Father.

Justice and love-righteousness and charity: is not that the whole of Christianity? Michelet, when a child, read with emotion the Imitation of Christ; he was the reverse of a cold rationalist, of an iconoclast; he had the true historical spirit of respectful sympathy for the past; he had "faith in faith and the love of love." He should have been an excellent Christian. Yet from 1843 to his death he was an irreducible adversary of historical and organised Christianity. Not only, at a time when State education was attacked with unscrupulous violence, did he deliver and publish, in self-defence, denunciatory curses against the priests and the Jesuits, but in March, 1848, when all was still hope and trust, when Catholies and socialists fraternised, he, the apostle of national reconciliation, was almost alone in sounding a note of diffidence and warning.*

There are three things in a religion: the Church, the doctrine, the spirit. The Church, in France, was the Roman Catholic. Now, this Church, in Michelet's mind, was opposed to his dearest objects of worship - the hearth, the Revolution. The hearth : the priest, bound to celibacy, to an unnatural ideal of absolute chastity, scorned family life, if not as unholy, at least as inferior, and was a stranger to the most legitimate and ennobling affections. The father should be a priest at the altar of his own fireside, and be united with his family in truest soul-communion; but the Catholic intruder, through confession, robbed him of his wife's spiritual allegiance, turned her against

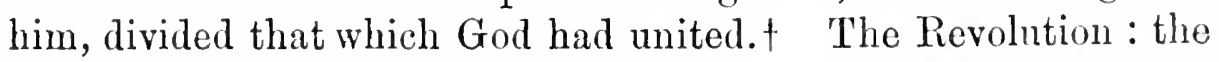
Church had unequivocally sided with autocracy; since the condemnation of Lamennais, no doubt was possible: the Church was the centre of all reaction, of the counter-revolution. $\neq$ And in the very spirit of love the Church was deficient: rich, powerful, ambitious, rebellious wherever it could not be tyrannical, it had become hard, materialistic. It was in the name of religion, of

- Une année au Collège de France, Le lendemain de la Révolution, 596.

† Du prêtre, de la femme, et de la faniille.

$\ddagger$ Les Jésuites. 


\section{FRENCH PROPHETS OF YESTERDAY}

charity, of the ideal that Michelet, like Quinet, George Sand, Victor Hugo, revolted against Rome.

Michelet drew splendid portraits of Luther and Calvin. Luther, especially, so natural, so popular, active, sincere, merry, and tender, won his heart. But, different in this respect from Quinet, he never was in active sympathy with Protestantism. The rival influences of Catholicism and eighteenth-century philosophy, which fought for dominion in his soul, were so strong that he could not escape from one without falling under the other. The Protestants were in close touch with England, which he hated; he could not bear the stiffness, the coldness, the reactionary spirit of their best-known representative, Guizot. An orthodox reformation, possible in the sixteenth century, was out of the question in the nineteenth. Therefore Catholicism stood as the sole representative of Christianity, and Michelet's hostility was extended from clericalism to theology. Monarchical and Christian idolatry, injustice, arbitrariness, favour, grace, all, he thought, were linked together ; he detested them all equally.*

Christianity and the Revolution agreed on the sentiment of human brotherhood, but the Revolution founded this sentiment " on mutual duty, on right, and justice," Christianity on "a doubtful historical conception, the common fall through Adam, the salvation of all through Christ." Grace, original sin, the small number of the elect, eternal punishment, shocked Michelet's sense of justice and love. In his eyes, Christian theology was irreligious. On all points he had a substitute for its doctrines. To the creation in seven days he opposed continuous creation, which excluded miracles, but not evolution ; to the Fall, his faith in moral progress, in the slow ascent of man through unending efforts ; to the condemnation of nature by the mediæval Church (Rabelais's Antiphysis), the rehabilitation of all legitimate joy, the Greek ideal of life, "a heroic smile" ; to the exclusive Judeo-Christian revelation, the universal revelation, of which each people writes a chapter, each great poet a verse, " the Bible of Mankind."

Michelet, in his earlier writings, had paid full tribute to the Christian ideal. Under the Second Empire, his radical anti- 
pathy to the Church made him more sensitive to the excesses, the contradictions, the obscmities, which, in his eyes, dimmed or marred the Divine character of the Bible. The aspiration to more justice and love, the glorification of sacrifice, were not specifically Christian, but eternal and universal. The Hebrew revelation, " beautiful and unsafe, even as Night," should not be deemed unique and exclusive. "Mankind pours incessantly its soul into a common Bible. Every great people wrote its verse therein." * Primitive India gave us the family in its natmal purity, in its incomparable grandeur, which no later age could surpass ; Persia, a lesson of heroic labour; Greece, the greatest of all arts, the art of making men. The hearth, work, education: these we owe to the three great civilisations, " a trinity of light and life, the main current of human thought." The Ergytians, the Phœuicians, the Jews were "the lesser half of mankind, the peoples of darkness and death" ; when Rome was conquered by the East, Syrians and Jews, she declined, and her decay made possible "the centuries of terror and gloom," which Michelet now hated as much as he once loved them, the Christian Middle Ages.

"Jerusalem can not for ever remain the centre of the world," such is the first conclusion of this survey. "Let mankind, free in its immensity, go everywhere. Let men drink where their earliest ancestors drank. With its enormous work, its tasks extending in every direction, its titanic needs, mankind must have much air, much water, much sky-the whole sky!-space and light, infinite horizons, the whole earth as promised land, and the world for its Jerusalem." +

Such universal worship cannot be narrowed down to the limits of a local and historical organisation; yet collective adoration, a ceremonial, are necessary. Michelet's ideal was the Greek festival: games, processions, the drama; in modern times, the "Federation" in 1790 and 1791. On the 4th of March, 18t8, took place a celebration in honour of the dead of February. With deep joy Michelet witnessed the admirable spectacle; a whole nation, pure, enthusiastic, fraternal; the flags of other nations side by side with the French tricolour. But the Govern- 


\section{FRENCH PROPHETS OF YESTERDAY}

ment had the unfortunate inspiration of holding the ceremony at La Madeleine (St. Magdalen's Church): "I did not go up. I had my church there, the great church of heaven. I held my celebration alone, under the sky, within my heart, saddened, however, at the spectacle of France shrinking in order to enter the little tomb." "We must turn about quickly, frankly turn our back on the Middle Ages, on that morbid past, which, even when it does not act, has a terrible influence, through the contagion of death. We must neither combat nor criticise, but forget. Let us forget and progress." $\dagger$

But this conclusion is negative, and negation is not Michelet's normal attitude of mind. The Bible of Mankind ends with a positive confession of faith, the best summary of Michelet's religion. "The hearth is the stone on which the City is builded. . . . It must become again what it used to be-an altar. . . . In the circle by the fireside should be admitted all the heroes of mankind, the great Church of justice. . . . It is illumined by a reflection from the universal soul of the worlds - Truth and Justice, impartial and immutable Love.

"It is this strong hearth that this book would help you build, or at least begin. It hopes to give you what it so often gave me, in the course of this long task, which absorbed me by day and woke me in the night: a heart at rest from all earthly trial, grave and holy joy, the profound peace of light." $\ddagger$

Michelet's religious philosophy is not systematic; it can neither be classified, discussed, nor refuted. The only original and positive point about it, the worship of the Revolution, cannot be fully appreciated by our generation. France was recovering from the shock of 1848 when the worse disasters of 1870-71 befell her; sixty years of diffidence and discouragement have been weighing upon her ; she is no longer in tune with Michelet's heroic optimism. She honours him, not as a prophet, but as a poet.

Michelet was too spontaneous, too individual a thinker and a writer to have any real disciples. Yet his influence was great.

* Nos Fils, 588. La Madeleine, built in the Greco-Roman style, in the form of a huge mausoleum.

† Bible de l'Humanite, 382.

† Ibid., 387. 
"Those of us whose childhood and early yonth were spent during the first twelve years of the Second Empire," wrote Gabriel Monod, "will ever remember the chill and weary gloom which oppressed their souls during that sad epoch. Youth, enthusiasm, hope, which had filled all hearts before and after 1830, seemed to have gone out for ever. . . . For many, and I was among them, the books of Michelet were then a comfort and a cordial. . . With him one gained faith in the future of the country, in spite of the sadness of the times. One could not escape the contagion of his entlusiasm, of his hopes, of his ever youthful heart." * If ever France dares once more to believe in her own destiny, Michelet's books, which now irritate or sadden her like a sarcasm or a dirge, will be again a source of inspiration.

\section{Victor Hugo.}

Victor Hugo's supremacy in French Romanticism is undisputed. He was the recognised leader of the school, as long as Romanticism could be called a school. Even men like Veuillot, Mérimée, Biré, who neither liked his opinions nor esteemed his character, were impressed by the bulk, variety, and excellenco of his literary production. A prince among poets, he became also the idol of the people: he is the only great writer whose name remains a household word; his funeral was an apotheosis. Like Napoleon, he is a part of the heroic legend of France.

To his literary supremacy and his eivic prominence, Hugo would fain have added the crowning glory of spiritual leadership. In the latter part of his career he wrote extensively on religious subjects. t The true prophets and priests, according to him, were the men of genius, the "Magi," $\ddagger$ among whom he felt assured of a high place. The study of Hugo's religious thought is therefore of commanding interest.

Unfortunately, even at present, it is exceedingly difficult. In his lifetime, and for many years after his death, partisanship on either side ran so high that a sane appreciation of his opinions

- G. Monod, Taine, Renan, Michelet, 178.

† Cf. La Fin de Satan, Dien, Religions et Religion, Le Pape, La Pitié Suprême.

$\ddagger$ Contemplations, vi. 23. 


\section{FRENCH PROPHETS OF YESTERDAY}

was almost hopeless. Whilst Veuillot and his friends would call him "Jocrisse à Pathmos," "garde national en délire" (a raving Philistine), the Hugolaters admired "even his warts," and made at least a demigod of him. In the eighties, his position was singular. Still active, ever youthful, he claimed his place in the van of progress, whilst his convictions and his imagination were those of a bygone generation; he was at the same time an ancestor and a contemporary; France admired him with a mixture of amusement and awe. A sharp reaction followed the apotheosis of 1885 . For ten or fifteen years it was the fashion, even for such a fair and sympathetic eritic as M. Lanson, to make sport of his apocalyptic pretensions; the numerous weaknesses of the "Magian" were mercilessly exposed. Renouvier's book on Victor Hugo: the Philosopher, was the sign and the instrument of a new reaction which restored the poet to his place among the spiritual lights of France. Even yet, this place is not well defined; Hugo played too great a part in recent history, he is too near us and at the same time too different from us, to be properly appreciated.

A second difficulty is that Victor Hugo's opinions changed repeatedly in the course of his long career. "I have grown," he used to say, as an explanation for these transformations. True; but his development was not strictly rectilinear. Old beliefs would, unexpectedly, incongruously, reappear amid a set of new ideas. The enrichment of Victor Hugo's philosophical experience was less in the nature of a growth than of a collection.

This may be partly explained by the attitude he assumed towards his times; he aspired to voice all the great tendencies of his century; his "crystal soul was placed by God in the centre of everything as a sonorous echo." He was, in the most exalted sense, the Poet-Laureate of France-a very legitimate and noble conception of his rôle. Unfortunately, this glorious part is a dangerous one. It leads to a certain subserviency to public opinion-so plainly visible in Tennyson - to the easy adoption of popular catchwords, and, all too often, to rank flattery of the powers that be-i.e., in nineteenthcentury France, of the populace. Now we must be careful not 
to over-emphasise this element in Victor Hugo. He loved popularity, no doubt; he cultivated it, with a sense of effective advertising that would have done credit to Barnum himself; he was not averse to a kind of theatrical eloquence and pose. English readers cannot help thinking that in his admiration for the Revolution, in his love for France and Paris, in his advocacy of democratic and social reforms, in his hostility to the Catholic Church, he was partly moved by the desire of flattering popular prejudices. But he shared these prejudices, if such they be, in all sincerity and to the fullest extent. In spite of his nobiliary pretensions, he was a man of the people, in natural sympathy with the aspirations, aversions, and enthusiasms of the people. Those who call him a time-server should remember that when he abandoned his party-the Moderates-in the Legislative Assembly (1849), that party was strongly entrenched in power; that in his opposition to the Empire he was with Quinet, the uncompromising champion of the rights of conscience against material success; that in 1871 he deliberately jeopardised his immense popularity by pleading the cause of the vanquished Communards, whom he had blamed before they were conquered. Vanity and self-seeking exist in Victor Hugo, but they do not explain all his career. We have to admit that as a thinker he was frequently neither spontaneous nor absolutely disinterested. With him, more than with any other writer, it is necessary to distinguish the three currents alluded to by Matthew Arnold:-

\footnotetext{
"Below the surface stream, shallow and light, Of what we say we feel; below the stream As light, of what we think we feel, there flows With noiseless current, strong, obscure, and deep, The central stream of what we feel indeed."
}

What Victor Hugo said and thought he felt, during the period we are studying, could be defined as orthodox Romantic Humanitarianism, with a touch of new-fangled science-worship. Victor Hugo had come to a full and open profession of these ideas later than most of the other great Romanticists. During the last three years of Louis-Philippe's reign, whilst Lamemais and 


\section{FRENCH PROPHETS OF YESTERDAY}

Lamartine, Michelet and Quinet were in active opposition to the Government, and had become the moral leaders of democracy, Victor Hugo was sitting in the Chamber of Peers ; whilst Lamartine and his friends conquered power in February, 1848, and lost it in June, Victor Hugo remained in the background; when he was, at complementary elections, sent to the Constituent Assembly, it was as a Moderate. His paper, L'Evénement, supported the presidential candidacy of Louis-Napoleon, the nominee of all the Conservatives, against Cavaignac, LedruRollin, Raspail, and Lamartine. In the Legislative Assembly he voted with the Right until the latter part of 1849 , when he became at last a Republican. It is true that, from this moment on, his evolution was extremely rapid; in a few months he passed from Moderate Liberalism to Radicalism, Anti-clericalism, and even a vague form of Socialism. But the suddenness of his conversion was not due to caprice, spite, or ambition. More or less consciously, all the elements of his new faith had existed in him for perhaps twenty years. He had supported the July Monarchy, but as a power of popular origin, and he considered himself a child of the Revolution and the Empire. He had not openly broken with the Church; but his conception of Christianity had long been that of Lamennais.* He had not made profession of Socialism, but his Humanitarianism had assumed other forms-pity for all victims, for the poor, for the fallen woman, for the prisoner; earnest and successful appeals in favour of men sentenced to death, whether they be common murderers or Revolutionists (Barbès). He, too, believed in the mission of France, and in his eyes the chief agent, the very incarnation of this mission, was Napoleon, "Napoleon, the god whose priest thou shalt be." In short, what Victor Hugo did in 1849 was merely to put his political and religious allegiance, as well as his vocabulary, in harmony with his long-established tendencies.

His resistance to the Coup d'Etat, which remains one of the most creditable pages in his history, his irreconcilable opposition

* Cf. his speech in praise of Pius IX., the then democratic Pontiff, House of Peers, January, 1848: it contains the germ of the long anti-clerical satire published in 1878 , Le Pape. 
to the Empire, the publication of Les Châtiments, gave him within the democratic ranks a supremacy that no one could challenge. None of the politicians, Ledru-Rollin, GarnierPagès, Raspail, not even Louis Blanc, was a great man ; besides, they were all disqualified by their failure in 1848 and further weakened by their dissensions. Lamartine was old, distrusted, disheartened, driven to hack-work by the pressure of poverty. Quinet, whose principles and attitude were similar to Hugo's, was less prominent in the political field and vastly inferior in literary genius; he possessed neither Hugo's absolute selfconfidence nor his Napoleonic gift of self-advertisement. In his island home* Hugo felt himself to be the High Priest of Romantic Humanitarianism.

In this quality, during the eighteen years of his exile, he expressed magnificently and dogmatically, $\dagger$ in prose and in verse, the orthodox beliefs of his sect. Liberty, equality, fraternity, reason, progress, science, the people, the Revolution; the primacy of France, a missionary nation, the elder sister of all, the apostle of the Rights of Man; the sacred character of Paris, the capital and the beacon-light of the world, Sparta, Athens, Rome, and Jerusalem combined; the futmre brotherhood of all peoples in the Universal Republic after all powers of darkness, priests, kings, and emperors have finally been exorcised; the eternal reign of peace, reason, and love-such was his Credo, such were his constant themes. $\downarrow$ These were noble ideals, no doubt, even though they lacked precision and consistency and took for granted a highly questionable view of

\section{* Jersey, later Guernsey.}

+ Victor Hugo considered himself so completely as a recognised spiritual power, the Pope of Free-Thought, that he addressed repeated communications to States anà nations (the United States, Italy, Spain), very much in tho nature of proclamations or encyclical letters.

+ On all these points Hugo's vehemence was his only originality, and even in this he had been anticipated by Lamennais; the Words of a Believer aro written in the same tone as Les Chatiments and parts of the Legend. Hugo insisted more than any one else on "the sacerdoce of Paris"-cf. Paris, Preface to Paris Guide, 1967, published separately with a fow other pieces on the same subject, Hetzcl edition; but there are many cvidences of the samo feeling in G. Sand and Micholet about 1848 and as far back as 1831 in Vigny's "élévation," Paris. 
modern history. They were nobly expressed, too, in spite of the riotous use of endless enumerations and violent antitheses. Some of Victor Hugo's best known poems * belong to this order. Yet, fine as these poems and speeches may be and much as they may have contributed to Hugo's fame with his contemporaries, they count for little in the spiritual history of France, of Romanticism, and even of the poet himself; for, although not insincere, they are not original. Hugo was playing in earnest his part as a "sonorous echo"; he was the orator rather than the prophet of democracy-an orator audibly prompted from below; unconsciously he was a general of the same kind as Ledru-Rollin, who said apologetically, "I must follow my troops, since I am their leader.'

Victor Hugo found it difficult at times to follow them where they wanted to be led. The hardening, lowering, materialising influences which were at work throughout the world did not spare the Democrats and free-thinkers. The disaster of 1848 still rankled in their minds; the apparent success of brutal force was a demoralising example; the aggressiveness, the intolerance of the Church party led to angry retorts and excessive counterafrimations. The new generation of Democrats were apt to distrust the unpractical idealism of their elders, whom they called irreverently "les vieilles barbes," and, instead of neoChristianity, they adopted pseudo-scientific materialism as their creed. Hugo went very far in his abuse of Catholicism and the clergy, very far in his praises of the new idol Science, of which he never formed a very clear idea. But, be it said to his great credit, there were limits beyond which he would not go. In spite of all his pæans in favour of the new spirit, he steadily refused to accept any form of materialism. Liberty, responsibility, immortality, the existence of God, remained essential parts of his philosophy. In the age of Comte, Littré, and Taine he remained faithful to the Vicaire Savoyard and M. Cousin. $\mathrm{He}$ fought shy of Darwinism, an act of intellectual timidity which bespoke great moral courage. On this point, and perhaps on this point alone, he deliberately courted the accusation of being old-fashioned.

* Stella, Lux, Temps futur's, visions subiime! 
We must insist on his attitude towards science, which was that of all the Romanticists. He wrote so many hymus to "the great deliverer," to schools which were to take the place of churches and make prisons useless, to investigators who were the true heroes and the true priests, that popular opinion, taking him at his word, counted him, with Taine, Renan, Littré, Berthelot, among the prophets of science. In this again he was naught but an echo. Besides, science was supposed to be the political ally of democracy, since the Church had made the irretrievable mistake of treating it with scorn or diffidence. When the Democrats were abandoned by Demos in 1848 and in 1851, they came to the natural conclusion that Demos needed to be enlightened; ignorance alone had kept him in the bonds of the past. For all these reasons Hugo added Science to his Pantheon, already well stocked with heterogeneous idols. How much he understood of the scientific spirit may be gauged by a typical piece, France et âme ("France and soul ") : "I thought," he said in a single sentence of fifty-seven lines, a fine instance of his power of rhetorical amplification-"I thought that the French Revolution was sufficient proof of the immortality of the soul,

"And when a grave Englishman, correct, well-dressed, wearing fine linen," Tells me, 'God made thee a man and I make thee a monkey,

Now show thyself worthy of such a favour,'

This promotion leaves me musing."

"Danton wrestling with Europe" may be sublime, and in the sixties or the seventies Hugo had a perfect right to consider Darwinism as an unproved hypothesis, but to adduce the one as an argument against the other is sheer Romanticism, which for most scientists is euphemistic for " nonsense." +

* "Beau linge," one of the most flagrant and unsuccessful chevilles (padding for the sake of the rhymo; here for rhyming with singe) in Victor Hugo.

† Indeed, we might even say that there runs through Hugo's production an undercurrent of hostility to science, which became more apparent as he grew older: (1) a keen sense of the limitations of science, incapable of inspiring a philosophy, and, great as it is, inferior to art (cf. William Shakespeare) and to virtue (Les Grandcs Lois, Légende des Siecles, 2nd series); (2) Scepticism: endloss contradictions of scientists among themselves ( $\left.L^{\prime} A n e\right)$; (3) Mysticism: the imagination of poets, an act of charity on the part of the humblest animal, go deeper into the secret of God than all learning ( $L e$ Crapaud). 
Victor Hugo, the Pope of Free-thought and Democracy, was neither ridiculous not contemptible, even though he was admired by readers of Le Siècle. But his philosophy was, if not secondhand, at least ready-made. The true Hugo must be sought elsewhere.

For Victor Hugo was also the "weird Titan," the "cloudweaver of phantasmal hopes and fears," to whom Tennyson paid such a noble tribute. When we pass into this other region of his genius, we find the same admirable art, and also, alas! the same excessive rhetoric: but the spirit is entirely different. The robust optimism which shone even in invectives and burst forth in triumphant prophecies has vanished, and with it the taint of Philistinism. The general effect is powerful, strange, and gloomy.

Powerful, but disconcerting. Hugo's philosophical poems* resemble his drawings-rays of lurid light shooting across Cimmerian darkness, half-revealing vague and monstrous forms, grimacing, impossible, yet strangely alive. Most readers prefer the broad daylight of popular Humanitarianism, commonplace but safe, or even the good old-fashioned Catholic religiosity of his earlier writings. The general public found these weird creations difficult, monotonous, oppressive. The philosophers ignored them as arbitrary and inconsistent.

We are not concerned here with their literary value: it must be granted at least that they embody an almost unique effort in French poetry, and that to fail in wrestling with the unutterable may be as glorious as to sing exquisitely Sarah the Bather or everlastingly to call Napoleon III. Tiberius. What is their spiritual import? Such is the only question before us.

The answer greatly depends on the author's own attitude. Was he an artist playing with ideas as he had played with rhymes and colours, or a prophet with a new revelation? Neither. He constantly referred to himself as the "Dreamer," and the word defines him admirably. He aspired to be more

* Contemplations, VIth Book: On the verge of the infinite; Legend of the Centuries: Vision, The Titan, The Epic of the Worm, The Satyr, The Trumpet of Judgment, Abyss, \&c.; God; The End of Satan; Religions and Religion; The Supreme Pity; The Pope; The Ass ; \&c. 
than an artist: truth, not beauty alone, was his aim. He was not a thinker: he despised the slow and uncertain process of logical reasoning. He was not, in any strict sense, a seer and a prophet : his visions, however vivid, were consciously subjective. He kept full control of his imagination, riotously fecund though it was. He never mistook his own creations for direct communications from powers unseen. The "Spirits," the "Voices," the "Shapes," so often found in his later writings, are manifestly literary devices. Yet he is always " on the brink of the infinite," striving to attune his human words to the ineffable. The result is a baffling compound of art and sincerity, of conscionsness and hallucination : a day-dream, in which the poet gives free career to his fancy, but never forgets he is dreaming: subconscious actor, half-walieful spectator of a drama played in his own soul.

This attitude is purely romantic: it is the triumph of individual sentiment and fancy over authority, tradition, and reason. But it is Romanticism at his highest and best: for it is individualism applied where it is most legitimate-the contem"plation of the great Beyond; and it is free from the damning delusion of Romanticism-the confusion between the true and the xsthetically pleasing. From the intellectual and the moral points of riew, such neglected books as The End of Satan and God are vastly superior to Chateaubriand's Spirit of Christianity.

The result of such a method cannot be a consistent and clearcut system. Hugo offered on almost every point a choice of solutions, which he adopted successively, according to his varying moods. Nay, he would offer them at the same time, and insist on their contradiction, taking pleasure and pride in their incompatibility. Antithesis was from the first his favourite figure of rhetoric; contrast was his "formula" in drama and romance; contradiction the very essence of his thought. After 1850, what had seemed merely an effective but overdone literary trick became, if not strictly a system, at least a constant habit of mind. Perhaps it would not be impossible to trace in this development the influence of Hegelianism. Not directly, of course: Victor Hugo was incapable of the patient 
effort which such a study requires. But before $1848 *$ Proudhon had used a similar method and staggered the world with his paradoxical and antithetic formulæ: God is Evil; Property is Theft-out-Hugoing Hugo and leaving his most violent effects of contrast far behind. The general spread of Hegelian thought + weakened the old aversion of the French mind for logical contradictions: for Voltaire's contemporaries, contradiction meant absurdity; for Renan's, it could mean profundity. Thus the resistance which checked Hugo's natural tendencies was partly removed. After 1851, the solitude of exile allowed him to develop still more freely. So, in his later works, he revelled abundantly in "thesis and antithesis."

Victor Hugo was a Manichean. He believed in a dual principle-God and Satan, spirit and matter, darkness and light. $\ddagger$ The power of evil became more and more real to him : the tone of his poetry grew more and more sombre. Probably the origin of this pessimism was in his own heart, so strangely compounded of strength and weakness: at the time of his full maturity, when all was his, wealth, glory, influence, his lower nature was asserting itself in dramatic contrast with the exalted purity of his young dreams. $\$$ The death of his daughter Leopoldine in 1843 further darkened his train of thought. Whatever his failings may have been in other respects, he was a loving father, and the wound he received then could never be healed. Christian resignation inspired his masterpiece, $A$ Villequier, but he could not help being haunted by the great problem which this death had set before him: "To whom do we belong then? Who owns us? Who leads us?... In ancient days, in the depths of heaven, to the eyes of the sombre Magian-Two formidable players appeared in the gloom-Which

* Contradictions Economiques, 1846.

$\dagger$ Evidence of this spread: Scherer's famous article in the Revue des Deux Mondes ; Gratry's and Hello's constant struggle against " modern sophists "the Hegelians.

$\ddagger$ His last line, on his death-bed: "C'est ici le combat du jour et de la nuit."

$\S$ The facts about his "lower nature" are gleefully set forth in Biré: Victor Hugo après 1830. Moral Manicheism : cf. Contemplations, II. vi., 11, $12,15,1854-55$. 
should we fear, and to which should we pray? Manes, shuddering, and the pale Zoroaster-Saw two immense hands move the stars-On the dark chess-board-Horrible thought! Do evil and good, from this vault-Hang over our brows? God, deliver me from doubt! -Sphinx, tell me the secret!" *

Finally, the success of the Coup d'Etat intensified his pessimism. The active part he had taken in the resistance made him feel the blow more keenly than Lamartine, George Sand, or Michelet. Political defeat was not the worst: the bitterness was to see a "crime" ratified by the sovereign people, to whose cause Victor Hugo had devoted himself; to witness, for many years, the prosperity of this hateful regime; to feel that everywhere in Europe reaction was triumphant. Yet the Second of December alone would not explain Hngo's sombre frame of mind. For if it saddened him, it also gratified his pride by giving him a rôle worthy of himself, by redeeming him in his own eyes and consecrating his glory before the world. $\dagger$

To the alternation, or the conflict, or the mixture of pessimism and optimism, both apparently systematic and extreme, was added another contradiction: that of fatalism and liberty. It would indeed be possible to distinguish in Victor Hngo at least four distinct and parallel conceptions of human destiny in this regard. We have he fatalistic optimism of his political speeches: "Progress is naught but a phenomenon of gravity, who shall hinder it? O despots! I dare you to do it: stop the falling stone . . . stop eighty-nine, stop the world hurled by God himself into the Light!" + By its side we have the fatalistic pessimism of his novels, and the tragic view of nature in many of his later poems. All his heroes die in despair. "A triple ananke (fate)," he said," weighs upon all creation. Notre Dame de Paris set forth the ananke of dogma, Le's Misérables, the ananke of laws; the Toilers of the sea, the ananke of Nature." The indifference, the cruelty of nature,

* Villequier, Septeinber 4, 1845, Contemplations, IV.s.

† Cf. Contemplations, V.3. Ecrit en 1855. "Je suis content!" VI. 21En frappant ì une porte: "Je n'ai rien à la conscience. Ouvre, tombeau!" † Actes et Paroles : Garibaldi, June 18, 1 S60. 
the horror of the universal struggle for existence, * took a strong hold of his imagination :-
"All suffer! Large and small, the bold and the prudent, All meet a hunter, a claw, a tooth!. . . Everywhere the woods are afraid; everywhere the beasts tremble With a shudder of anger and terror; it seems
To whoever sees creation from one side only That unspeakable hatred fills the firmament. ..."†

History is even darker than nature. The Legend of the Centuries is a sombre tale of catastrophes, treasons, and crimes. The kings are monstrous tyrants; the people are ignorant and cowardly; the just are ever sacrificed. $\ddagger$ Still gloomier is The End of Satan: the sword, the cross, the prison, are the symbols of all human history. The natural conclusion of pessimistic fatalism is moral irresponsibility. Ignorance and Night alone are guilty. The most unreserved indulgence seems to be "supreme pity," but it is only justice.\$

* This before Darwinism, often made responsible for this pessimistic conception of the universal struggle for life, could have any influence upon him. It was simply a manifestation of his general pessimism.

† Dieu: L'Ange, 189; cf. also Dolor, Contemplations, VI. 17-The Mouth of Darkness, Contemplations, VI. 26. Toilers of the Sea, second part, iv. : 2. God: the Bat, the Angel.

$\ddagger$ Welf, Castellan d'Osbor: le poète à Welf.

$\S$ Fatalistic pessimism and optimism are hard to reconcile. V. H. attempted such a reconciliation in Night Voyage, Cont., VI. 19. This world is a ship on which all is horror, ignorance, confusion; "Progress, a wheel with a double gear (?) can set nothing in motion without crushing some one." But the ship, not the crow, knows the way, "And one feels that one is carried towards the light."

Another attempt is the catastrophic theory; the past is dark, the immediate future darker. But one last Revolution, one last war, and the world will be rid of the enemies of progress--kings and priests. This is the usual mystico-revolutionary ideal, with a strong Apocalyptic tinge (Armageddon, Millennium).

A third is the belief that science will cure all human ills, by a sudden discovery which will radically transform the world-_."the conquest of the air," aviation (Légende des Siecles, Plein Ciel). One fails to grasp the opposition between "Leviathan"- the Great Eastern-as symbol of all the darkness and injustice of the present, and the airship, representing the freedom and splendour of the future, for the steamer was also a product of 
A third conception is naturalistic pantheism. This, expressed as early as 1837 in the famous piece The Cow (Voix Intérieures), was reaffirmed in Les Contemplations, Les Châtiments, ${ }^{*}$ and inspired in the Légende des Siceles the wonderful poem The Saty, as well as the Iyymn to the Earth in the third series. It points neither to hope nor despair, neither to love nor hatred, but to a serene acceptation of the laws of universal life. It is non-moral and fatalistic.

With a fourth conception, Hugo absolutely breaks away from fatalism, whether optimistic, pessimistic, or indifferent. In the Legend, Conscience (Cain), The Parricide (Knnt), and in all his works, innumerable passages, either symbols or direct expression of his belief, posit liberty and duty as the laws of human life, with their corollaries, responsibility and immortality: "I want to be free here below, responsible elsewhere-I am more than a stalk of grass or a grain of sand-I feel I am, for all eternity, thinking, winged, living." †

But what form will responsibility assume? Here Victor Hugo offers us a bewildering choice of solutions. They express all possible degrees of conviction, from deeply-rooted belief, through hypothesis, myth, passing flight of fancy, to mere verbal figmres. Sometimes he alopted the Christian tradition of a Judgment Day at the end of time (The Trumpet of Judgment, Légende des Siècles). A favourite conception with him

human science. We have to accept two assumptions, one erroneous, the other mythical: (1) Aerial navigation is a victory over gravity.

"Gravity, fastened to the foot of mankind,

Was broken: a chain which was all the chains."

(Plein Ciel). (2) Sin, suffering, darkness and gravity are synonymous.

"God created only the imponderable being.

Now, the first $\sin$ was the first weight.

Weight assumed a form; it fell, dragging the angel down."

"Tout alla s'aggravant," almost a metaphysical pun. This conception offers a curious case of an image, reduced for most of us to a verbal and meaningless figure, transformed into a doctrine, or rather into a myth, by the powerful and primitive imagination of a poet. Note that while evil is gravity, progress is also spoken of as a " phenomenon of gravity."

* VII. 12: La Force des Choses.

† Les Grandes Lois, third Legende des Siecles. 


\section{FRENCH PROPHETS OF YESTERDAY}

was Conscience as the avenger. Admirably symbolised in the eye which followed Cain even into his tomb (Ia Conscience), or the slow rain of blood on Knut's shroud (Le Parricide), it pervades les Chátiments. A stranger doctrine which he often expressed in his conversations, * before he gave it public utterance in Religions and Religion, is that of optional immortality. Annihilation is the worst punishonent; personal feeling is to be trusted, whether it affirms or negates eterral life: "Dante wrote two lines, then went out, and the two lines spoke to each other: 'I am immortal,' and 'I am doomed to perish.' Some one entered: it was Dante himself. He kept the first line and struck ont the second. . . One died, the other lived: both were right." t The astral theory, later proponnded by Jean Reynand in Earth and IToacen, had already tempted him. We sliall wander from star to star, "reading the infinite Work and the eternal poern-line by line, sun by sun." The guilty will be imprisoned in satmrn, "hideous and fomidable globe," or in horrible plantom worlds, careering throngh the "invisible and the impalpable." \$ Lastly, the strangest of all these hypotheses, the nost personal, and the one on which he insisted most complacently, was that of unicersal metempsychosis, of transmigration, not nerely from man to man or from man to beast, but lower still, from least to trce, and from tree to stone, "which is Hell." Man is one link in the chain which reaches fronl the andels down to the lower worlds, to the abyss where one sces "a hideous dark sun from which Night radiates." The whole miverse is alive, full of souls. Sin drags us down, eveis to the level of brute rnatter, "a stone is a cave in which a criminal lies dreaningr." "Nimrod groans, confined in the abrupt mountain... the pincers which glow in the hideons brazier-Are made with the Duke of Alva and Philip the second. .. "T This conception is so foreign to our modern

- E.g., to Stapfer in 1868.

† Religions et Religion, iv.

\$ Saturne, Cont., III. 3, 1839.

$\S$ Inferni, Lég. XXXII., third series.

II God: The Angel, 208.

- The Mouth of Larkness, Cont., VI. 261. 
habits of thought that it is diffieult to consider it as anything but a brilliant literary theme. Yet it probably meant much more than that to Victor Hugo. The insistence with which he developed it in The Wouth of Darkness, the immense place he gave it in the parts of God where he manifestly expressed his favourito ideas, lead us to think that he more than half believed in this strange doctrine. We should bear in mind that with his rank imagination, his absolute self-confidence, his lack of external or internal cheeks in the way of common sense, humour, tradition, or the scientific spirit, Victor Hugo was more akin to the primitive Seer than to a modern thinker.

Manicheism, while it recognises the separate existence of two principles, does not necessarily maintain that these two principles are co-eternal. Hugo's sombre poems end invariably in a song of hope. Eril will finally be eonquered, or rather redeemed, transfigured, absorbed. Belial and Jesus will be brothers. Matter, darkness, negation, hatred, will vanish; light and love alone will rule. How will this be achieved? Through suffering mude meritorious, transmuted into sacrifice by the operation of liberty. Such is the meaning of the central myth in the End of Satan. The last feather from Lucifer's wing, as he fell from heaven, was saved and turned into an angel, Liberty. Liberty is the daughter of God and Satan, of rebellion and love. Throngh her Satan himself will be saved: no longer able to deny, to hate, he still despairs: he cannot be forgiven, for He whose name is Love hates him! "No, the archangel rises again, the demon ends; Satan is dead: be born anew, O eelestial Lucifer!"

The ultimate question remains: "What was Hngo's conception of God?" $\mathrm{He}$ did not spare his criticism to all anthropomorphic representations of the Absolute. On this point, his anti-clericalism and his philosophy were in accord. $\dagger$ One thing is certain: God was a living reality to him, and in spite of a number of pantheistic passages an unshakable belief in the personality of God is manifest in all his writings. Finally,

- La Bouche d'Ombre, end, 1855 ; Plein Ciel, Dieu: L'Ange.

† Cf. Légende, les raisons du Momontombo; Année T'errible: A l'Evéque qui m'appelle athie; Ieeligions et Religion. 
he devoted to God-or rather to the idea of God-a long poem, which, written in 1855, was not published until 1886.*

After listening to "Voices," which attempt to discourage him from his quest, the Dreamer, in his mystic ascent, meets a succession of symbolical Beings, each immeasurably above the other, each the bearer of a partial revelation. First, the Bat, who represents Atheism, and whose answer is : Niliti. Then the Owl, who stands for Scepticism, and to the great question replies: Quid? and the Raven, the symbol of Manicheism, whose solution is: Duplex. Next comes the Vulture of Paganism, the one who was eating Prometheus's liver until Orpheus bade him cease and follow him. The word is : Multiplex; there are gods, "but the gods are not the causes." In spite of apparent failure, Prometheus's task is done. "The flame is stolen: it is on earth-Where?" asks the poet-but the Vulture disappears. Higher still soars the Eagle: his revelation is: Unus-he stands for Mosaism. There is one God, avenging, terrible, jealous, visiting the sins of mortal man on twenty generations. $\dagger$ The spirit of Christianity is a Griffin: God is a trinity; His principle is love, forgiveness, clemency. "No, says the Angel with one wing white and the other black, who voices Rationalism: God is Truth. Neither avenging nor clement, He is just; to avenge an insult is to notice it and deserve it. To be clement is to be unjust for all those who are not forgiven." There is no eternal Hell, but eternal progress through suffering, an ascent in the whole scale of creation, from infra-matter to superspirit. $\neq$ Highest of all is the living Light, who reveals " that which is still unnamed"- "Vengeance, pardon, justice are human words. He is. What is He? Ask no more! Darkness is the question, the world is the answer. $\mathrm{He}$ is. He cannot be

* This long delay in publishing a publicly announced, fully completed poem, the work of the author's maturity ( 1855 is the date of many admirable pieces in Les Contemplations), cannot be satisfactorily explained.

$\dagger$ The exposition of Mosaism, as Hugo calls it, is curiously intermingled with Brahmanic elements : this world is a dream of God, and will cease to be when God awakens.

† The revelation of the Angel is practically a duplication of "What the Mouth of Darkness said" (Contemplations). Same central doctrine-universal metempsychosis ; same four-rhymed couplets with a lyrical conclusion in six-line stanzas; same date. 
named. Love alone foreshadows Him. For to be is to love. $\mathrm{He}$ is. Nothing exists but He alone. All the rest is a dream. Light, O Light, eries the poet, is this all? And the Light answers: Silence! ... Blind is whoever thinks he can read, and insane whoso believes he knows." Then the poet meets a Shape, who says: "What sleeping man can know, thou knowest. Dost thou wish to reach the goal, to see the invisible, the unnamed, the ideal, the real? Yes! I cried. He touched my brow with his finger. And I died." This at last was Day.

No abstract can convey the impression made by this weird and powerful poem, the feeling of breathless ascent from the material through the spiritual to the very gates of Life. If it does not sum up all philosophy, at least it gives us the essence of Hugo's : a passionate quest for the Ultimate Truth, universal curiosity, and, as supreme answer, awe-struck silence.

Is this to be deemed a failure? If the making of consistent systems be religion, Hugo undoubtedly failed. We have considered in him the "orator" and the "poet." The former was commonplace; the latter, through numberless and conflicting phantasmagorias, ended in a confession of impotence.

But when all the weaknesses of the man have been pointed out, all the limitations of the poet, all the inconsistencies and absurdities of the thinker-his frantic and overwhelming rhetoric, his ignorance, on which his assumption of omniscience threw a glaring light-when all is said, Hugo remains Hugo, one of the five or six supreme poets of mankind.

In the religious field he was great in three different ways. First of all, as the poet of conscience. He took a hackneyed theme, the story of Cain, and by sheer force of conviction and genius he told it again with the directness and impressiveness of an ancient prophet. What La Conscience is among his symbolical poems, Ultima Verba is among his political, and the oft-quoted line, "Et s'il n'en reste qu'un, je serai celui-la," is more than a happy phrase, it is a lesson and a "Sursum Corda." Hugo made his whole life under the Second Empire a slightly rhetorical but magnificent ode to conscience and duty.

Then he is great as the poet of love, or rather of pity. In 


\section{FRENCH PROPHETS OF YESTERDAY}

songs of selfish passion, great virtuoso as he is, he is inferior by far to the sincerer Musset. But his heart was ever filled with ardent sympathy for the poor, the weak, the sufferer everywhere. Whether in his immense prose epic, Les Misérables, or in poems, perfect like the Toad, or excessive like Sultan Mourad, he preached the same lesson: "Be kind! Thou searchest, O philosopher? O thinker, ponderest? Dost thou wish to find truth under our accursed mists? Believe, weep, lose thyself into the Unfathomable Love!" (Le Crapaud). And in this again he lived by the law he taught.

Finally, in a nation which had not yet fully disowned King Voltaire, in an age when philosophy and religion had alike become materialistic, against the full tide of Positivism and Ultramontanism, he was a passionate seeker after God, and with all his contradictions and his exaggerations, he succeeded in communicating to his reader something of his own intense yearning, something of his shuddering ecstasy before the unutterable. 


\section{BOOK III}

\section{CHAPTER I}

THE NEW SPIRIT-BACKGROUND AND INFLUENCES

\section{Characteristics.}

Political revolutions, with their sudden and spectacular changes of personnel and vocabulary, have no exact counterpart in the world of thought and feeling, in which modifications are seldom so sweeping and so instantaneous. Yet the transformation which took place toward the middle of the nineteenth century has often been called an intellectual revolution, and it deserves that name better perhaps than any movement since the Renaissance.

In the late forties and the early fifties, a new spirit, after a sullg process of development, came to full consciousness and assumed definite forms. To get away from abstractions and fancies; to turn one's back on mystics, romanticists, schoolmen, doctrinaires and metaphysicians of all kinds; to seek nothing but sober truth, whether it be pleasant or unpleasant, moral or in apparent contradiction with accepted notions of morality; to expect truth only from the dispassionate study of facts: such were the cardinal points of the new doetrine. Empiricism in government, industrialism in the economic and social world, realism in art, the experimental method in science, positivism-in its broadest sense-in philosophy: all were parallel manifestations of the same tendency.

In France, the success of the new spirit was rapid and 
complete. By 1855 the battle was virtually over: the "Theologians," whose social power was still formidable, were hopelessly defeated in the field of thought, and have never recovered their advantage. Those of the older writers who were still adaptable were strongly influenced by the scientific spirit: Michelet, Quinet, George Sand, Victor Hugo, did at least lip-service to the new goddess; while de Vigny and SainteBeuve kept fully abreast of the times. With all the leading men of the rising generation, the same inspiration prevailed; Flaubert and the Goncourts were its representatives in the novel, Dumas and Augier in the drama, Scherer, and especially Taine and Renan, the princes of them all, in criticism, history, and philosophy.

There had been no lack of great scientists in France before the second half of the nineteenth century; but never had their special turn of mind and their method ruled the world to such a degree. The scientific spirit of the fifties differed in many ways from that of the Renaissance or the eighteenth century. First of all, it lacked the element of joyousness, almost of intoxication, which is generally inseparable from any great forward movement, and which was so noticeable in the two earlier periods. Then it was pervaded with the comparatively recent notions of relativity and evolution. Finally it had developed the experimental method to such an extent as to make it almost the whole of science.

It is a striking fact that, complete as the triumph was, no elation went with it: the victors were modest, subdued, almost pessimistic. For the movement was not merely one of expansion, of conquest; it was a reaction as well, and a reaction against much that men hold dear. There was no doubt but Romanticism, democratic Christianity, Utopian Socialism, were admirably attractive: they appealed to our best instincts, the virtues of faith, hope, and charity; they roused optimism and enthusiasm, they called to action, they held forth the mystic lure of a golden age near at hand. They ended in apparent failure, and a great chill fell over the world. 
It is not the trinmph of science, therefore, but the collapse of Humanitarianism, which was mainly responsible for the sombre colonring of French thonght mider the Second Empire. It was not Darwinism, for instance, that created a brutal and pessimistic conception of life; it was this pre-existing conception which interpreted Darwinism in terms of its own disenchantment. The Days of June, the Coup d'Etat, covered France with moral ruins; these science could not repair in a moment, as poets and prophets rear their dream-palaces with a single word. "Whence-whither? Why is there such an abyss between our lower instincts and our aspirations? What is right, what is wrong? Why should we choose the one rather than the other?" To these eternal questions, science had no definite answer to give. We want, for the past, an explanation; for the present, a guide; for the future, a hope: these science could not offer.

Thus, if science did not create the gloom which prevailed during that period, it failed to dispel it. Slowly, patiently, it continued its work: serene, disinterested, indifferent to lnuman judgments and human sufferings, it seemed to many immoral, frivolons, or harsh. Yet it saved many noble sonls from selfishness, scepticism, and despair. If science could not fathom the ultimate, at least it could indefinitely extend the limits of the relatively certain ; if it could promise no millenmium in the near future, it assured immediate and constant improvements; if it could not formulate an indisputable code of moral laws, it proved that it conld inspire the lives of saints and martyrs. Thus gradnally the old spirit of confidence was returning, chastened but strengthened, when the Franco-German War and the Conmune determined a new pessimistic reaction."

* The pessimistic tone of French literature under Napoleon III. was sometimes ascribed to the influence of Hartmann and especially Schopenhauer. As a matter of fact, neither of these men was widely known in France until after the war. It was Challemel-Lacour's article in La Revue des Deux Mondes (Un Bouddhiste Contemporain en Allemagne, March 15th, 1570) that made Schopenhauer famous in France. Challemel-Lacour was himself a thorough pessimist, as well as a great writer: unfortmately, his literary career was cut short by politics (cf. Etudes et Réflexions d'un Pessimiste, published in 1901, but written between 1861 and 1869). Mime. Aekermann had no difficulty in proving that her pessimism at least owed nothing to tho 
The second striking characteristic of the new spirit was the predominance of two ideas, relativity and evolution. As long as science was conceived on the type of mathematics, the discovery of static laws was its only goal; their application to physics, and in particular to astronomy, seemed the highest achievement of the human mind; man had thus the absolute within his grasp. The world was the sum of these unchangeable laws, hierarchised in such a way that, from generalisation to generalisation, some future Newton would come to the ultimate synthesis, to the supreme formula which gives the key of the whole. The notion of eternal order prevailed : that of development was neglected. As for God, His rôle was singularly restricted: the order fixed once for all left Him no part in His universe. According to Descartes, He had given the "first fillip" that started the machine; according to Voltaire, $\mathrm{He}$ was a convenient hypothesis; according to Laplace, a useless one.

This scientific dogmatism, centring in the idea of absolute law, seems to us more akin to metaphysics and deductive logic than to true science: it is a form of Rationalism. It did not disappear at the end of the eighteenth century; as late as the Second Empire its influence was still great, not only on Taine, who was primarily a logician, but on the subtle and "wavy" mind of Renan. The notion of law remains at least an indispensable working hypothesis, and the most radical empiricists use it without scruple; but in the course of the nineteenth century this notion underwent a great change; it lost much of its absolute character.

The first cause of this transformation was the irreparable ruin of traditional authority. In attacking "abuses" and "superstitions," the philosophers of the eighteenth century started a critical movement which went far beyond their intention. It undermined not only Catholic practices and theology, but even the simplified form of Christianity which they had to offer under the name of Natural Religion. The Catholic

German philosopher, although, as she spent a number of years in Berlin, she had a better chance than most of her. compatriots of being influenced by German thought. This is a case when the apparent cause is indeed but a rosult, 
reaction in the nineteenth century was either sentimental or social: intellectually-in the realm of abstract truth-the lost ground was never reconquered. Cousin and the Eclecticists soon reduced their ambition to revamping Voltaire's and Rousseau's theism; but, although their doctrine was taught in all State schools until the end of the nineteenth century, it was laughed out of court by Taine in 1857, and lightly brushed aside by Renan with his best smile of courteous contempt. Between the old synthesis and the new there was an interregnum, which was naturally filled by scepticism, ever ready to take the vacant place. It was not Montaigne's amused, easy-going pyrrhonism, but a deeper, more melancholy form of doubt. Hugo himself, Sainte-Beuve, Taine, Renan, Leconte de Lisle, were repeatedly driven to the same conclusion: "We know nothing ; all is illusion."

The Catholic philosophers-Gratry, Hello, Dupanloup-and, to a certain extent, that semi-cleric Caro, ascribed the development of scepticism to Hegelian influences, and Scherer, in his great article on Hegel, adopted the same view. Hegel is so ideally un-French in his mode of exposition that his direct action was not considerable. Certainly, what he himself held to be the central point of his doctrine-the possibility of reconstructing the universe by a mental process, the identity of the rational with the real-found no acceptance west of the Rhine; it was metaphysics with a vengeance, at a time when metaphysics were ntterly discredited. His conception of God inspired Vacherot's works, * a noble but isolated attempt, and Renan used it to great advantage for wriggling ont of the dilemma, Theism or Atheism ? But it was chiefly Hegel's dialectical method, the resolution of contradictions into a higher synthesis, and so ad infinitum, which impressed the French mind. The principle implied in this method is that nothing is true or false, nothing is right or -wrong, in and by itself; that all humau notions and judgments are relative; that the absolute-in spite of certain venturesome developments of Hegelianism-is beyond our reach. This view tallied so well with the actual state of aflairs-the collapse of all absolutistic doctrines in presence of destructive criticism- 


\section{FRENCH PROPHETS OF YESTERDAY}

that it found wide acceptance. Some adopted it with a sort of stoic joy, others with the unspeakable anguish so eloquently described by Scherer.

An age which believes it already possesses absolute truth, or at least that absolute truth is accessible, can afford to neglect history. The nineteenth century, so restless, so sceptical, threw itself with a sort of passion into the study of the past. Vico, Herder, had paved the way. In France, it was one of the essential elements of Romanticism. Chateaubriand's Martyrs kindled the vocation of Augustin Thierry. Whilst the Classicists had insisted on all that is permanent and general, it was differences, contradictions, peculiarities, that attracted the Romanticists. The historical spirit and the notion of relativity worked admirably together, for the study of the past shatters dogmatism, whilst relativism alone enables us to understand and to sympathise with vanished civilisations.

Yet history remained long encumbered with traces of metaphysics. "Philosophies" were devised, to which facts were made to conform. This was very striking, before 1848 , in the case of Quinet and Guizot. Sainte-Benve offered a much better example of disinterestedness in his Port Royal. Renan and Taine were loud in their protestations of scientific impartiality. As to the validity of their claims there is much to be said, for the old notion of rigid law died hard, and more than one "scientific historian" is but a rationalist in disguise.

The prevalence of the historical spirit in literature in the nineteenth century, especially after 1848, is undoubted: the poetry of Leconte de Lisle, the novels of Flaubert,* the whole production of Saint-Beuve, Taine, and Renan bear the same mark. This was only a continuation of a certain aspect of Romanticism, but more thorough and less subjective.

It was in the study of religions that this historical attitude of mind wrought the greatest revolution. Hitherto the only alternatives had been dogmatic assertion or destructive criticism.

* Madame Bovary and L'Education Sentimentale are written exactly in the same spirit and according to the same method as the "historical resurrection" Salammbo; cf. especially the scenes of the Revolution of 1848 in L'Education. 
The new spirit aimed at supplanting both. Voltairianism, without information, without terms of comparison, without insight or sympathy, appeared frivolous and vulgar. Strict orthodoxy, wilfully blind to the facts of evolution, refusing even to discuss the claims of rival orthodoxies, seemed bigoted and ignorant. A new way was opened: opened by the Germans again,* followed by Quinet, Sainte-Benve in his Port Royal, and Renan, who, although coming late, made it emphatically his own. It was a winding and cantions path, which the hastyminded would spurn; yet it bronght men nearer to their goal, faith reconciled with science, freedom with reverence, the spiritual autonony of all harmonised into liberty.

Finally, we must note the trinmph of the experimental method: Bacon dethroned Descartes. The natural sciences, based on methodical observations rather than on abstract reasoning, made wonderful progress. The scientists of the Second Empire whose names reached the general public were first of all great experimenters. ${ }^{\dagger}$ Claude Bernard called physiology "experimental medicine," and in his Introduction to the Study of that science, he gave the true Novum Organum of his time (1865). Pasteur, who was not yet, in the popular imagination, the wizard, the demigod that he was to become, gave a practical demonstration of the method in settling, for many years to come, the vexed question, partly scientific, partly metaphysical, of spontaneous generation. Berthelot, whose intellectual influence was great, through his friendship with Renan, and on account of his own breadth of interests, did his best work in chemical synthesis: he was an indefatigable laboratory worker.

The name of Darwin is so indissolubly linked with the scientific revolution of the middle of the nineteenth century, his books attracted such wide attention and roused such a heated controversy, that we are often tempted to over-emphasise his rôle.

* Unless one considers as a crude and early attempt in that line Dupuis's Origine de tous les Cultes. Creuzer was Quinet's master; Littré translated Strauss; Renan paid many a tribute to Germany's superiority in the scientific study of religion. The influence of Oriental studies, especially with Burnouf, should also be mentioned.

† Excepting Le Verrier (1811-77) whose mathematical "discovery" of Neptune (1816) made a lasting impression upon the French mind. 
Whatever the claims of Darwinism may be in the field of pure science, its success in the general development of thought was a sign of the times, not a starting-point. All the tendencies, the habits of mind, which are so often carelessly ascribed to Darwin's influence, the notion of evolution as well as the experimental method, were clearly formed in France before Clémence Royer translated The Origin of Species in 1862. On the contrary, Lyell, whose name has not remained so famous, seems to have impressed more deeply men like Renan and Edgar Quinet.

Historical and natural sciences lent each other a inutual support: the former-archæology, philology, comparative mythology -provided the notion of growth, which was so fruitfully applied to the study of the organic and even of the inorganic world; the others taught that absolute adherence to facts which history, on account of its long association with philosophy and literature, was still prone to neglect; they tanght the necessity of checking every assertion and hypothesis through experimentation; they demonstrated the vanity of all unnecessary and unprovable theorising. The combined influences worked wonders. The accuracy and disinterestedness of science became the ideal, not only of critics, but of poets as well. Sainte-Beuve's field was "the natural history of minds"; Taine was a "naturalist" ; Zola, whose formation belongs to the last years of the Empire, claimed to write "experimental novels." Needless to say that there was much "literature"-fortunately for us-in all this pseudo-science. In certain cases, Taine and Leconte de Lisle, for instance, some charm was lost-the charm of personal warmth and spontaneity. But, on the whole, the influence of science on French thought and literature was wholesome: it provided a much-needed discipline after the orgies of sentimental Romanticism.*

\section{Positivism: Saint-Simon, Comte, Littré.}

The French philosopher who gave the new spirit its most definite formula was Auguste Comte, and in his honour the name

* It has been said that in the scientific spirit there were three elements: the rational, the idea of law, was French; the historical, the idea of growth and evolution, was German (pre-Darwinian) ; the practical, the experimental method was English. 
Positivism is often adopted to cover the whole movement. But we should not forget the disciples of Comte's forerunner and first master, Saint-Simon. As an organised sect, the SaintSimonians had long ceased to exist. Individually, they were still prominent in many fields, and a curious aspect of what is often loosely called Positivism - the religion of material productivityis directly traceable to their influence.

Saint-Simon, who was a failure in practical life and the most chaotic of utopists in his writings, had the intuition of two or three ideas which remain cardinal points in modern French thought. The first was that, after the long and victorious campaign of destructive criticism in the eighteenth century, the time had come to restore, to build up; the second, that no stable society could exist without a spiritual doctrine and a spiritual power. So far, he seemed to agree with the Reactionists and the Theocrats, with de Maistre, Bonald, and Lamennais. But he also affirmed that the medireval or Catholic synthesis was out of date; that the world needed a "Now Christianity" based on the one unshaken foundation, Science; that in the new world, instead of priests and captains of war, we should have scientists and captains of industry. Thus science would replace theology, industry would replace worship : all for the service, not of a metaphysical Being beyond the world, but of that which is ourselves and more than ourselves, real and ideal at the same time-Humanity.

Industrialism and Humanitarianism were thus both contained in Saint-Simon's doctrine, if doctrine be the word for the evershifting pronouncements of a mystic Bohemian. They were reconciled in a sort of Socialism which made "the welfare of the most numerous and poorest class" the first duty of the State, and suppressed the right of inheritance, whilst reserving the greatest honours for the captains of production. After the extraordinary mystic crisis of 1829-32, the school was disrupted. The influence of its humanitarian teaching on the Romanticists could be easily traced, especially through Pierre Leroux, and under the Second Empire the survivors of the sect, Father Enfantin and Barrault for instance, still adhered to what may be called " the religion of '48." But the other side of Saint-Simonism, the cult of in- 
dustry, developed in a more striking manner. Saint-Simon, in this respect, had indeed been a prophet; for he died in 1825, and in France, at that time, industry in the modern sense was still in its infancy. It was not until the early forties, when France at last followed England in railroad construction, that the new power fully asserted itself. The Saint-Simonians found themselves immediately in the front rank of industrial leaders; they carried into the practical field their religious qualitiesenthusiasm, generosity, a remarkable loftiness of purpose.

There is no reason to believe that Napoleon III. was ever, consciously and formally, a Saint-Simonian, but his ideal coincided with theirs. Industrialism and Socialism combined, such was the economic formula of the Second Empire, as, under a mediæval mask, it is that of modern Germany. Free Trade was a Saint-Simonian principle, and it was a former Saint-Simonian, Michel Chevallier', who, through the direct action of the Emperor, arranged the commercial treaty of 1860 with England. Railroad extension was a dogma with the sect: their Pope, Enfantin, was a capable railroad official. The first great steamship line became a Saint-Simonian concern. The Suez Canal, in which Napoleon III. took such interest, had been promoted and surveyed by Saint-Simonians.

It is through Saint-Simonianism that a number of democrats, like Guéroult and even Sainte-Beuve, were reconciled with the Empire. George Sand herself accepted the dogma of productivity as a form of Humanitarianism.* Especially among the liberal middle class, many "Progressists" who professed to be believers in science were, first of all, believers in industry. About, the brilliant but shallow representative of that class, said: "I am of the religion of Littré." But his book on Progress shows that he was rather a Saint-Simonian.

Unfortunately, the idealism that ennobled the original SaintSimonians, the touch of what their detractors called "mystic mania," did not pass to their followers. The ideal of the "captains of production" did not remain priest-like: it became as materialistic and selfish as possible. Industry was not a means of social service, but a short cut to wealth and pleasure. "I see 
the salvation of all at the end of this career opened to unrestrained individualism," said George Sand: it took all her indomitable meliorism to see so far into the future.*

Yet we must not forget that Saint-Simonianism was, with a fow men, a sincere and genuine, althongh insufficient, form of religion. There are many at the present day for whom a gigintic industrial enterprise means more than a moneymaking proposition: they are the "mysties of industry," and Saint-Simonians in their hearts. The religions capital of mankind is not so large that we can afford to despise any part of it, even the least pure and the most incomplete.

From 1818 to 1822, Anguste Comte was Saint-Simon's disciple and assistant. Their collaboration continued, but not so wholeheartedly, until 1824: at that date, Comte, who was a highly trained mathematician, could no longer be satisfied with the seductive but hazy theories of his erratic master. Henceforth he worked independently, and had no comnection with the later Saint-Simonian sehool or sect. His private correspondence shows that many of lis most important ideas were fermenting in his mind even before he met Saint-Simon; but his indebtedness to his master is still considerable. The central doctrine of Positivism is that of the "New Christianity": the world nust be reorganised, spiritually as well as materially, on a scientific basis.

But whilst Saint-Simon's mind was riotously imaginative, Comte's was essentially systematic, and the two cardinal features of his philosophy are classifications: the law of the three states and the hierarehisation of sciences.

The three states are the theological, the metaphysical, and the scientific or positive. During the first, man songht to explain natural phenomena by the action of Beings, more or less similar to himself, endowed at least with personality and will. According to the number of these beings, we have fetishism, polytheism, or monotheism. When the difficulties of such

* This corresponds with one of the meanings of the word "positiviste" matter of fact, practical, bent on immediate, tangible results. Nany objections urged against Comte's Positivism are true only of de Morny's or Schneider's. 
explanations became apparent, the personality of the governing beings grew fainter and fainter, until, instead of fetishes, spirits or gods, men spoke of "forces" or "principles." This was but a dematerialised and devitalised form of theology, "a mythology of abstractions," and constituted an intermediate state called metaphysical. Finally, we are entering upon a new state-the scientific-in which realities are studied in themselves, withont any interposition of imaginary influences-persons or abstractious. But modern science is still encumbered with metaphysical notions, which are only sneaking dogmas. To purify science from these anti-scientific elements is our first duty.

The next step will be to co-ordinate all branches of knowledge into an organic whole. Unity is not only a guarantee of truth -here we recognise the Frenchman and the Catholic--but also a condition of progress. Chaotic efforts lead nowhither. The order proposed by Comte is at the same time historical, logical, and practical. At one end are Mathematics, the first sciences to be brought to a high degree of perfection, the simplest in their essential elements, the most general in their application. At the other stauds Sociology, the latest science, since it was "invented," or at least baptized, by Auguste Comte himself; the most complex of all, and also the most special in its object-social man. In between come Astronomy, Physics, Chemistry, Biology. Each science presupposes those that precede it in the list, adds something thereto, and limits itself to a narrower field. In Comte's words, they are arranged " according to the order of increasing complexity and decreasing generality." The whole constitutes the framework of a philosophy and a practical programme of studies.

Such were Comte's leading ideas in the first part of his career (1824-42). The second part is far more important from the religious point of view. As a normal development of his reconstructive principles, and under the influence of his ideal passion for Madame Clotilde de Vaux, he apparently reverted to Saint-Simonian mysticism, and organised, in all its details, "the religion of Humanity." This last phase, however deeply interesting in itself, and often misrepresented, is not within the scope of the present work. For it was totally withont influence 
on contemporary thought. "Positivism," as popularly understood, was the philosophy of Littré, and Littré parted company with his master just on account of this late mystico-sentimental development.

The influence of Comte was considerable: Sainte-Benve, Taine, Renan, the protagonists of French thought under the Empire, were Comtists in more ways than one-but without knowing it. For the direct and personal authority of the master was indeed eurionsly small, and limited to the little societies where his true doctrines were preserved. Guizot, in his Memoirs, seems to cunsider the philosopher as an obseure erunk. Renau seldom mentions him, and hardly ever withont ill-disguised aversion. Taine, a Positivist in everything but in name, confesses his debt to Stuart Mill, but not to Comte. Pasteur wrote to Sainte-Beuve: "I have read nothing of M. Comte, except a fow absurd passages" (1865). Sainte-Benve himself, in his enthusiastic notice of Littré (1863), seemed to consider Littré's adhesion to Comte's system one of the few weaknesses of his hero. It was not until the comparatively recent studies of Messrs. Levy-Bruhl and G. Dumas that the confusion between Littréism and Comtism was at last cleared away.

Littré was neither a great philosopher nor a great writer. He expresses himself as he thought-clearly, honestly, withont a spark of genius. Yet the life of this unassuming, undersized, ill-favoured scholar ranks high in the free-thinkers' Golden Legend, for he was, in the words of Anatole France, "the most learned and the best of men." "He was," said Lamartine's niece, Madame de Pierreclos, "a saint who did not believe in God."

He was an agnostic and called himself an atheist. Extremely tolerant in his daily relations, he was intellectually blind to anything but scientific rationalism. "The most assured precept of positive philosophy is to abandon all speculations about the begimning and the end of things; these speculations are uscless since they are hopeless; good enough for the infancy of the race, they are unworthy of its maturity." "The result of scientific investigation is that there is, in the sequence of things, 
either in the inorganic or in the organic world, no trace of miracle, or of government from above ; any such belief is henceforth, as Laplace said, a useless hypothesis."

Littré's open profession of materialism and atheism, coming from a man of such learning and of such sterling moral worth, seemed in flagrant contradiction with the words of the Psalmist: "The fool hath said in his heart: There is no God." Iittré irritated the Theists, not merely as an opponent, but as a monster. It seemed to them that, in being neither a fool nor a knave, he was not playing the game. Their lostility was such that the great lexicographer, whose titles to a seat in the Academy were incontestable, was kept for ten years from this deserved reward, and when he was finally elected, his irreconcilable enemy, Mgr. Dupanloup, sent in his own resignation. A new generation has come, and Littré's second-hand philosophy is forgotten. But the great scholar, so modest, so thorough, so useful, who did alone the work of many men, is still remembered with respect. "To love, to know, to serve, and, as we advance in life, to cultivate the memory of those we have lost, such is the forndation of our moral existence and of our lasting happiness." These words, at least, contain no negation, and he lived nobly up to his programme: "To love, to know, to serve."

\section{P.-J. Proudhon.}

"Le blasphème des grands esprits est plus agréable à Dieu que la prière interessée de l'homme vulgaire; car, bien que le blasphème réponde à une vue incomplète des choses, il renferme une part de protestation juste, tandis que l'égoisme ne contient aucune parcelle de vérité."-Renan, Dialogues Philosophiques, Preface, p. xv.

In the very title of his article on Proudhon (1858), Scherer declared Socialism bankrupt. Coming half a century later, we know that Socialism was not ruined, as one might have expected, but only transformed, by the scientific spirit. Before 1848 it had been Utopian, idyllic, optimistic, vaguely Christian, in a word Romantic. After that date it became realistic, matter-offact, "scientific," harsh and sombre on the whole, and often frankly atheistic. This new phase in its evolution is generally commected with the name of Karl Marx. In France, where 
Marxism penetrated but slowly and had no appreciable influence on national thought, the chief agent of this transformation, which remained incomplete, was a man whom Karl Marx did not like, and probably did not understand-P.-J. Proudhon.

Uncouth, diffuse, chaotic, over subtle, naively sophistical, puzzling and provoling for bourgeois and socialist alike, Proudhon was none the less a noble soul, a stimulating thinker, and an admirable writer. Historians of French literature too often pass him by, or dismiss him with a contemptnous paragraph ; he cultivated none of the recognised genres, and his innumerable publications need thorough sifting and careful editing. When this is done his place will be assured by the side of Venillot, among the few men of the people who showed commanding literary talent. Less varied in tone, less clear, less classical than the great Catholic jourmalist, he is far superior to him in depth, seriousness, and dignity. Morally, both rank high; they led pure and unselfish lives. But whilst Venillot, even when under the protection of the Government, took pleasure in deriding, insulting, slandering his enemies, Proudhon, even when unjustly persecuted, attacked and defended naught but ideas. He had the earnestness, the passion, and the forbearance of a prophet.

In religion Proudhon stands, first of all, as the most outspoken representative of antitheism, and many persons know nothing more about him than the two oft-quoted apophthegms: "Property is T'heft" and "God is Evil." And this last was not an isolated sally, a chance paradox: in almost every one of his books Proudhon took pride in his position as a " hlieophobist," God's personal enemy. "If God exists, He is essentially hostile to our vature. . . We attain to science in spite of Him, to wellbeing in spite of Him, to society in spite of Him : cvery step forward is a victory in which we crush the Deity. . . Why didst Thon deceive me? Why didst Thou submit me is the torture of universal donbt? . . The Satan that lies in wait for us, it is Thee! But now, Thou art dethroned, and Thy power broken. Thy name, for ages the last word of the scientist, the sanction of the judge, the strength of the prince, the hope of the poor, the refuge of the repenting sinner, Thy name, Thy in- 
communicable name, henceforth abandoned to scorn and curses, will be hooted down among men. For God means foolishness and cowardice; God means hypocrisy and deceit; God means tyranny and destitution; God is Evil.".*

That there is much rhetoric in this declaration of war is obvious. This is literature, at least as much as religion and philosophy. It is an echo of the Byronic-Satanic school, a belated spasm of decadent Romanticism. Such " sulphuric" declamations were commonplace enough, and for that very reason harmless. Merely from the literary point of view, the passage is noteworthy. Baudelaire, Leconte de Lisle, Mme. Ackermann $\dagger$ may have borrowed their blasphenies from Lncretius, Goethe, Byron, Shelley; but they must also have known Proudhon. The spirit, the crescendo, the very words of the tirade, are reproduced so faithfully in Leconte de Lisle's masterpiece, Qaïn, that the resemblance can hardly be fortuitous.

Yet Proudhon was not a professional man of letters-neither a sophisticated æsthete and sentimentalist like Baudelaire nor an impassible word-artist like Leconte de Lisle. He was a plain man of the people, writing on the spur of irrepressible convictions. Insincerity was not his sin, but lack of self-control and culture. Who has not heard well-meaning and earnest working men express their thoughts in terms of extreme violence, simply because they had not the exquisite taste and the extensive training of a Renan or of an Anatole France? Such is the curse of untutored strength. Eloquence was a fatal gift for a man who, not ignorant, but self-tanght, was easily carried away by the flow of his own words.

Proudhon was an original thinker, a blazer of trails; but this quality is too often paid for by iconoclasm and love of paradox. More than once his imagination, his dialectics, led him so far astray that he seemed to express exactly the reverse of what he had in mind. His book against war + was considered by many as an apology for war. He was conscious at times of his failing, his talent for rousing opposition, his excessive violence. But, as

* Systeme des Contradictions Economiques, ou Philosophie de la Misère, 184.6.

$\dagger$ Ackermann was a friend of Proudhon's, and corresponded with him from Berlin. 
a rule, this only served to make him proud. "I became Terror Incarnate. I have been preached against, put on the stage, in songs, on placards, in biographies. I have been blamed, insulted, and cursed." Visibly he relished his Satanic triumpin. To personal friends he would occasionally confess: "Such is the effect of my unfortunate style. Unconsciously and against my will things will grow larger, and clearer, and sharper under my pen, so as to bite into timid imaginations."

But it would be a poor way of serving Proudhon's fame, and of understanding his message, thus to explain away his most characteristic dictum. There is rhetoric, and exaggeration, and pose in his antitheism; there is much earnestness too. Merely from the negatire point of view, such passion reveals a religions soul which cannot quietly ignore God, but needs a violent effort to reconquer its liberty.* Proudhon was one of the few great men of letters of his time and country who read the Bible. $t$ He studied Hebrew ; he sedulously annotated the Scriptures; he had come to the same conclusions as Strauss before he had heard the name of the German historian. He was preparing a book on Jesus when the success of Renan's made him give up the idea, not without reluctance. His imagination was Christian and his turn of mind theological. He was a heresiarch, a belated Gnostic rather than an unbeliever.

And there was a positive side. Proudhon was not a Nihilist, like Mérimée and Leconte de Lisle. He was not a pessimist either. Amiel misquoted his axiom when he applied it to Schopenhauer's philosophy, "Evil is God." Proudhon was an independent Positivist, a self-tanght Hegelian and Comtist. With Comte he held that there were three periods in the development of thought: the first religious, the second sophistic, the third scientific. $\$$ With the Romanticists and Utopian Socialists he believed in progress and in humanity. "Mankind is a being, which has its own functions, different from our individualities; its ideas, which it communicates to us ; its judgments, which

* "Un positiviste profondémentreligioux qui ne peut se déprendre de Dieu que par la violence et l'insulte."-MIar. Mathieu.

+ Victor Hugo and Vigny wero also great readers of the Bible; not many others.

$\ddagger$ Contradictions Economiques, i. 10. 
do not resemble ours; its will, diametrically opposed to our instincts... a being which, issued from nature, seems the god of nature, whose potentialities and laws it expresses in a superior-hence supernatural-degree." With Hegel, whose method became the very law of his thinking, he believes in the relativity of all human notions and judgments. Certitude is found only in laus, because they are mere relations-and even only in laws of movement, not in laws of existence. Proudhon is a relativist with an intensity of passion which is at times positively amusing. The absolute, which he also calls idealism (as if that unfortunate term had not already a sufficiency of confusing meanings) - the absolute is his personal enemy. "Truth, that is to say reality, in nature as in civilisation, is essentially historical; it is subject to progressions, conversions, evolutions, and metamorphoses. There is nothing fixed, nothing eternal but the laws of change. Truth is that which changes."

If God means the absolnte, then war to God! A God in the making-mankind striving towards a full conscionsness of itselfsuch a God he would accept; or the God of the Freemasons, snch as he himself, brushing away the effete Pousseanism of the Brethren, reinterpreted in terms of Positivism. "The God of Freemasonry is not absolute; he is a relation, a balance (symbolised by the level, the plumb-line, and the square). In declaring war, according to my perhaps unfortmate expression, on all substantial, causative, verbal, justifying, and redeeming gods, Elohim, Jellovah, Allah, Christos, Zeus, Mithra, I was unwittingly in accord with the unconscious thonght of Freemasonry. .. I Iffirm that the sovereign and regulating idea of the future will be that of Relation, Balance, Right." †

We now begin to understand Prondhon's antitheism. "God" is whatever obscures truth and warps justice. It is all a question of definition. There is some disadvantage in accepting a definition so absolutely contrary to general usage. Proudhon was aware of this, and repeatedly he relapsed into common parlance and common sense. He duly apologised for this: "I need God as a hypothesis," he said, "in order to show the connection between civilisation and nature; in order to prove ny

* Philosophie du Progress, 1851.

† De la Justice, \&c., vi. 76. 
goodwill to a multitude of sects, whose opinions I do not share, but whose anger I fear; in order to justify my style, for without this 'indelible superstition' we can neither speak nor actnor even think." * It is hard to see the difference between such an indispensable "superstition" and a fact as certain as any law known to mankind. Proudhon's enemy, therefore, is not God, "the mysterious Creator, whom my conscience, of its own accord, supposes," + but a certain conception of God opposed to his own; not even so much the Absolute as the God of Absolutism : the God of Caprice as opposed to the God of Justice, the God of the Church as opposed to the God of the Revolution.

Such is the meaning of his "magnum opus," Justice in the Revolution and the Church. Pyrrhonism is spreading: the comntry does not believe in anything, and knows it-1848 has tanght France at least this one lesson. Pure Liberalism has collapsed; authority is once more our panacea. But neither liberty nor authority are ends in themselves; they are only methods. We need a regulating principle, superior to both. This Proudhon calls Justice-we may call it God.

But wherein does this principle reside? Two solutions are proposed. According to the first, the principle is transcendent, beyond man. Nan knows it only through revelation, and his duty consists in obeying even when he does not understand. This conception is the basis of all authorities; it is the doctrine of the Church.

According to the second solution, the principle is immanent; it 1s within man, in his very nature; the individual conscience is antonomous. This is the basis of liberty, the doctrine of the Revolution.+ +

In a series of twelve Studies, $\S$ encyclopædic in matter and

* Contradictions Economiques, i. 25.

† Ibid., i. 374.

+ By which is meant, not the incomplete movement of 1789-92, nor the spirit of restlessness and blind destruction, but the etcrnal spirit of enfranchisement and progress; the Reformation in the past, the Social Revolution in the present and the near future. For "immanence and transcendence," cf. again R. J. Campbell's New Theology: "To restate Christianity in terms of the immanence of God," leading, theoretically, to the divinisation of Humanity, practically to Socialism, just like "Orthodox" French Humanitarianism.

$\S$ The first and last bcing Introduction and Conclusion. 
prolix in style, but teeming with ideas, and instilled throughout with the love of righteousness, Proudhon compares, on every great question, the rival solutions offered by the Revolution and the Church, his criterion in every case being the notion of Justice. The Church lowers human dignity, for it teaches the total depravity of man as the result of the Fall, and makes Right consist in a command from above, Duty in mere subjection.* It does not condemn the present arbitrary repartition of riches, preaches to the poor resignation and to the rich charity, which perpetuates pauperism. $t$ In the State, its doctrine is that of divine right and absolutism. $\downarrow$ As it places the seat of moral authority outside the individual, the education it gives, by repressing independence without being able to suppress it, fosters hypocrisy.\$ The Church has declared labour a curse and the servitude of the poor eternal.\| It has corrupted the public mind, as its impossible craving for the absolute leads to nothing but scepticism and sophistry. It ruins conscience, for any code of ethics not based on conscience is not moral, and no [theological] religion can accept conscience as its basis without committing suicide.*** It holds the pessimistic and demoralising view that mankind is decadent, instead of the healthful belief in Progress. $+\dagger$ It has corrupted love and marriage, by introducing into them mystic and absolutistic notions, the last consequence of which is lubricity. ++ In every case the great culprit, the archdeceiver, the embodiment of all evil, Satan, is the notion of the Transcendent, of the Absolute, the God of the Church.

Hence Proudhon's declaration of war, which was no mere flight of rhetoric, for imprisonment, poverty, exile were its clearly foreseen consequences. "I have taken as my model the Dacian peasant $\$ \S$ speaking to the Senators of Rome; I have

* II. "Des Personnes."

† IV. "De l'État."

II VI. "Du Travail."

** VIII. "Conscience et Liberté."

$\dagger$ III. "Des Biens."

$\S$ V. "De l'Education."

TI VII. "Des Idées."

¥† X. and XI. "Amour et Mariago" - two chapters which form a book by themselves, and would be worth reprinting. Remarkably earnest, paradoxical and stimulating. Cf., in particular, his ideas on art-showing his contempt and horror for sheer Romanticism.

$\S \S$ Lafontaine's Paysan du Danube. 
placed myself in spirit before the Church, iwith my labouring man's smockfrock, my peasant's clogs, my journalist's pen, and my only thought has been to strike hard and straight." His own faith is summed up in one word, Justice-superior even to Love and Liberty; his method, in this declaration: "The world probably forms an isonomous, homogeneous, harmonions whole, and the laws of my reason are therefore the same as the laws of the universe.* I have only to follow my reason, constantly checking it by experimentation."

At the close of his book, the grim old fighter, with touching simplicity, extends his hand to his adversary, Bishop Mathien of Besançon, offering to honour and follow the Church if the Church, recognising God as the growing conscionsness and conscience of mankind, will accept the spirit of the Revolution : "Then I shall recite with you, with a fervent heart, without any mental restriction, and covering myself with the sign of the Cross, this magnificent collect which closes the evening service, on Sunday, in our Besançon churches: "Nay the peace and benediction of Almighty God, Father, Son, and Holy Ghost, Liberty, Justice, and Lore, and may the visitation of His Angels descend upon us; upon this city and all who therein dwell in its commmnion; on the fruits of the earth and on those of labour; on the remains of the faithful who rest here and everywhere in the faith of Christ and of the Revolution; and may His grace keep in justice their souls united with ours' (et animas eorum salvet et nostras)." †

If Proudhon's changing and confusing attitude could be fixed in a formula, we should say that practically he was an anti-.Catholie, intellectually an agnostic Positivist, spiritually a believer. In early life he swore to devote himself "incessantly, with all the energy of his will and the power of his mind, to the complete enfranchisement of his brethren and companions." This promise he kept scrupulously to his dying day. He had many imperfections, but of the intellect, not of the heart. He knew neither hypocrisy nor fear, and he was persecuted for justice' sake.

- Cf. Hegel.

† Words in italics are Proudhon's addition to the Latin text. 


\section{CHAPTER II}

\section{THE POETS OF SCIENCE AND DESPAIR}

CAtholicisu, throngh its alliance with political reaction, had lost its mystic glamour. The vast, generous, and stormy aspirations of Romanticism had led to the disaster of June, 1848. Mysticism, imagination, and passion had thus proved deceptive lights. For the noble souls who would not be satisfied with political empiricism and material prosperity, science remained the only refuge.

But a cold and gloomy refuge it seemed, after such glowing hopes. It seemed as though poetry itself were crushed like the idealistic Republic of Lamartine, the ntopian Socialism of Leroux, the ardent democratic Christianity of Lamennais. A period of poetical barrenness was therefore expected. Victor Hugo was at the height of his powers, but in exile, and the last glorious representative of a vanishing gencration. Lamartine and Musset had ontlived their poetical faculties. Vigny was lhalf forgotten in his "Ivory Tower." Poetry seemed to have shrunk to the cold and minute perfection of Gautier's Emaux et Camées, to the morbidity of Baudelaire's Fleurs du Mal, to the elaborate trilling of that lyric punster and acrobat, de Banville. Three exquisite poets, to be sure, but three "poets of decadence."

The antinomy between science and poetry remains to this day a favourite theme with fledgling bards. About 1850 it seemed even more radical and hopeless than at present. Poetry in the previous two or three decades had become quasi-synonymous with Romanticism, and science, more intolerant than it is now, 


\section{THE POETS OF SCIENCE AND DESPAIR 181}

seemed to preclude its very essence: the haunting sense of mystery, the free play of imagination, the constant underemrent and the splendid outbursts of passion. Vigny himself, of all the great Romanticists the most scientific-minded, wrote in his Maison du Berger (The Shepherd's Cabin), "Distance and time are conquered. Science-'Traces round the world a sad and straight road.-Our experience has caused the world to shrink-And the equator has become too narrow a ring.-Chance is no more: each one will glide on his line-Motionless in the rank assigned to him at the start,-Absorbed in his silent and passionless computations."

Such was the impression of the contemporaries and of the generation immediately following. Yet, beside the Epigoni of Pomanticism and the shallow worshippers of Art for Art's sake, there were a number of isolated poets directly inspired by philosophy and science, the intellectual brothers of Comte and Darwin. Some were poets of the first magnitude, like Vigny and Leconte de Lisle; others were simply distinguished, like Mme. Ackermann, Louis Bouilhet, Louis Ménard, André Lefèvre, and their successors, Sully-Prudhomme and Jean Lahor; none is contemptible or even indifferent. To the present day these writers have not received their dne meed of praise. Their reserve, their apparent coldness, the somewhat hard and tense beanty of their style, the rigour of their thonght, the sombre hue of their religious opinions, will ever debar them from wide popularity.

\section{Alfred de Vigny.}

Alfred de Vigny, the forerumner and the master of this school - if indeed we may call this arbitrary grouping of kindred but unrelated individualities a school - is not generally considered as a poet of the Second Empire, but as an early Romanticist. Yet several of his best poems in The Destinies were written miler Nipoleon III. ; the book-his masterpiece-and the Diary of a Poet were not published until after his death in 1863; and the lonely, half-forgotten writer, who seemed to belong to an earlier generation, expressed more powerfully perhaps than any other the thoughts and feelings of the 


\section{FRENCH PROPHETS OF YESTERDAY}

period we are studying. Yet we must not believe that there was a second Vigny different from that of 1823. Vigny changed less than his companions. If the Victor Hugo of 1822 and the Victor Hugo of 1853 could be brought suddenly face to face they would not at first recognise their essential identity. Vigny's philosophy grew, but consistently with itself. His Moses and his Silence, at forty years' interval, are different, and yet in full harmony. "Absurd is he who never changes," runs the oft-quoted French proverb, but consistency is not always due to narrowness and stubbormness; it may come from genuine strength of mind, and from such a lead over one's contemporaries that their progress fails to overtake the pioneer. Victor Hugo was perhaps too sonorous and ready an echo; Vigny struck fewer notes, but they were his own, and none were ever purer or deeper.

This very consistency ought to warn us against any attempt at finding in Vigny's life a clue to his philosophy. Vigny could be studied as "a pure spirit," if we may apply to him a favourite phrase of his. Radically different in this respect from the great Romanticists, he hated anything that savoured of self-revelation. His most personal poem, La Colère de Samson, is in the form of a severely objective symbol, and we have come to wonder whether the allusions that critics read into it are not purely fanciful. He took elaborate precautions to prevent his private life from being dragged into the glare of noonday. "No one," said Jules Sandean, "has ever lived on intimate terms with M. de Vigny-not even himself."

It is true that his most cherished ambitions were successively disappointed. He found nothing in the army but an obscure and useless servitude; the princes he served proved unworthy of his loyalty: "In politics his heart died in July, 1830"; he accepted all regimes (Louis-Philippe, Republic, Empire) without reluctance and without enthusiasm. His private life was not a happy one. He chafed at times under the mean and constant tyranny of aristocratic poverty. His wife never was the soul-mate he deserved; she died after years of ill-health, during which he was her devoted attendant. He himself suffered for 


\section{THE POETS OF SCIENCE AND DESPAIR 183}

twelve years from the terrible disease which, in his Olympian language, he referred to as "the vulture of Prometheus." Are these circumstances the cause of his pessimism? Let us go back thirty or forty years, to 1823. Alfred de Vigny was then twenty-six years old, strikingly handsome, a nobleman, a soldier, and a poet, universally beloved and admired; and yet it was then that he wrote his Moses, no mere Byronic declamation like Musset's Rolla, but the strongest and most deliberate expression of utter weariness, disenchantment, and despair. And his very last poem, The Pure Spirit, is full of hope and of grave, deep joy. Life did not make Vigny a pessimist; he conquered his inborn and reasoned pessimism in the face of adversity. There is not a nobler victory.

The study of Vigny's life does not enable us to understand the trend of his thought: we shall find little more enlightenment in his ontward attitude to organised Christianity. A Catholie by birth, he never severed his formal connection with the Church of his ancestors. * His poems prove that he was an assidnous reader of the Bible; he knew the Imitation by heart, and in his old age, far as he had wandered from orthodoxy, he read Father Gratry's Sources with reverent appreciation. Through his wife and some of his best friends, like the "Puritan" Camilla Maunoir, the was in touch and in sympathy with Protestantism. With his inborn gravity, his love for tradition combined with freedom, his lofty individualism, he certainly seems more of a Huguenot than of a Romanist. His very appearance in middle age was that of a minister. M. Léon Séché would place him among the Calvinists of Catholicism-the Jansenists. Reserve, gravity, a proud and gloomy conception of life, he lad mueh in common with the "Solitaires" of Port-Royal. The man who admitted no one into his intimacy belonged to the fiumily of those who, after twenty years of life in common, still used with one another the ceremonious form of address: "Monsieur." 'The great problems of Grace and Predestination were always present to his mind as to theirs, and are the keynotes of his last and best poems, Les Destinées. His Diary often reads like a con- 


\section{FRENCH PROPHETS OF YESTERDAY}

tinuation of Pascal's Thoughts. Yet we do not believe that Vigny would have accepted the label Jansenist, or that the genuine descendants of the Solitaires would have recognised him as one of them. No direct filiation, no formal adhesion, no decisive influence can be proved; and of the three names of sects which his life and philosophy would naturally suggest -Calvinism, Jansenism, Stoicism-he himself adopted the last.

"When Death comes he [the man of honour] looks on the Cross with respect, fulfils his duties as a Christian as a matter of form, and dies in silence." * Such was his own attitude thirty years later, reverent and reserved to the end; but long before, without any apparent crisis, he had lost all faith in the religion which he formally professed. He liked and respected the priests, but he knew that they had forfeited the spiritual leadership of the modern world. $†$ With the more sombre aspects of Christianity, "a religion of despair," with the sorrowful moments in the life of its Founder, he remained in fullest sympathy; but traditions and dogmas were in his eyes legends and myths. These myths were full of meaning and beauty, and well worth preserving; $\ddagger$ but they were arbitrary and ever changing: "Christianity is an eternal chameleon." § He was a deeply religious man, but in his own words, "Christianity was dead in his heart." $\|$

A passionate seeker after truth, he saw in such a quest the very essence of religion. I "God is not a tribal law-giver, and a faith is more than the metaphysical justification of a moral code, more than a transcendental police-court. The men who, like Descartes and Spinoza, have tried to find ont the 'cause and the end of creation' are more deeply religious than those who, like Angustine, Bossuet, Fénelon, assumed that the universe was made for the sake of one small people. The former point of view is grander, more Divine. It is inspired by that sacred love of truth which lifts the soul up to the Creator and the centre of His creation. This immense per-

* Journal d'un Poète, p. 86, dated 1834.

† Ibid., pp. 40-345.

+ Ibid., p. 146.

$\S$ Ibid., p. 93.

II Ibid., p. 86.

ฯ Ibid., p. 168. 


\section{THE POETS OF SCIENCE AND DESPAIR 185}

spective far transcends the petty interests of our human molehill, and even the notions of good and evil, which are lost and drowned in it like bits of straw." *

Vigny's religion, therefore, is neither one of action nor one of sentiment, but a religion of thought. Like Pascal, he considers Thought as "the whole dignity of man." He speaks of Ideas like a Spanish mystic-in terms of almost sensuous love. Reason and Justice, the instrument for knowing Truth and the will that Truth shall prevail, are "the queens of his thonghts," + and "the true God, the strong God, is the God of 'Thought." +

This is Rationalism, no doubt: but we are far indeed from the shallow eighteenth-century worship of reason. Vigny's love of truth, passionate, disinterested, neither self-centred nor selfsatisfied, implies a duty rather than a boast ; it remains religions even when it seems to blaspheme.

For pessimism is the first fruit of his quest, not joy and peace. The pioneer-prophet or poet-is donmed to isolation. This frivolous and materialistic world lills the too sensitive sonl with its jeering indifference (Chatterton), or stands in awe of the divinely inspired prophet, who, in his power and loneliness, aspires "to sleep the sleep of the earth" (Moses). He yearns for human love-but Delilah betrays him to the Philistines (Samson's Wrath). Devotion to a high ideal, genius, is a curse. In the pessimism of Vigny's earlier writings, this is perhaps the most striking element.

Yet what man worthy of the name would refuse the gift because of the curse? "Weak souls are afraid of pure Enthnsiasm," he said in The Shepherd's Cabin: "but why shrink from it? Life is doubly life in its tiame." And in the Bottle in the Sea he repudiated any intention of drawing back from the honour and danger of the poetic mission: "Courage!" he writes to a young poet. "In your holy devotion to the work of the future forget yourself, forget the man in you." He would no longer complain, as in his youth; for he had "risen to that high degree of stoic

* Journal d'un Poite, pp. 168-169, abridged translation.

+ Les Oracles, Postscript, 1862.

+ Bouteille à la Mer, 1858. 
pride" which makes it seem " equally cowardly to groan, to weep, to pray." * If a man would adopt "the diviner point of view " in religion, his first act must be to renounce his personal interests in this life and in eternity. Bent exclusively on knowing truth, the thinker must suppress his yearning for happiness, for glory, for the sympathy of nature and of man. He must lose all concern in his individual destiny. Pessimism, in its personal aspect, is thus silenced by stoic renunciation.

Yet self-renunciation is but a negative achievement. Even after the veil of petty interests is removed, the world remains dark, "without light, without stars, without dawn" (Mount of Olives). Man cannot abdicate his craving for truth and justice withont abdicating his dignity as man; but this craving is never satisfied. Our universe seems to be ruled by blind and pitiless Fate (Les Destinécs). For Lamartine, the heavens proclaimed the glory of God, the firmament His handiwork ; for Hugo, not consistently, but repeatedly, Nature herself was divine. Vigny was not blind to Nature's beauty, nor insensible to her soothing and ennobling influence; indeed, the opening stanzas of the Shepherd's Cabin rival in picturesque precision the best lines of Victor Hugo, in tenderness and harmony the most famous of Lamartine's. But does Nature really tell a wondrous tale of intentional beauty and beneficent order? Men of Darwin's generation could not answer Yes. "Nature is our tomb as well as our mother; she hears neither our cries nor our sighs; she is an impassible stage, unmoved by the feet of the actors, indifferent to the comedy of our human life, which vainly looks above for silent spectators." +

Vigny never doubted but there was a God beyond Nature and "its vain splendour." There is a God: but evil, too, is a fact. You may call it illusion, guilt, ignorance, matter, fate, you may disguise it under as many names as you please: you cannot deny its existence. If God be all-powerful, then we are not free: fate " in antiquity and in the enslaved East, grace in the Christian West, weigh upon us like a leaden yoke" (Les Destinées). If $\mathrm{He}$ be just, can He be responsible for undeserved sufferings, for the death of children, for this whole world of sin and sorrow? 


\section{THE POETS OF SCIENCE AND DESPAIR 187}

(Mont des Oliviers). If $\mathrm{He}$ be loving, why does $\mathrm{He}$ not answer our supplications, why did the noblest of His sons cry to Him in vain on Mount Olivet? Happy in comparison was Moses, the prophet of old, estranged from men, but the friend of God. The second form of Vigny's pessimism is deeper and more hopeless than the first.

There is an essential contradiction between the existence of God and the existence of evil. Yet we cannot deny either. Evil offends our sense of justice and love, and who but God can bear the ultimate responsibility for it? Hence Vigny's strange but logical attitude: not atheism but antitheism-and that on strictly religions grounds. God and nature are alike in their pitiless impassibility. They may crush us, they do not command our love. Pascal had said before Vigny that man was greater than nature; but he is morally greater also than the God of orthodox Theism, becanse he can give his life for a principle and the Deity camnot.* Before such a God our knees must not bend; rather should we oppose Him, like the young man who killed himself " to aftlict and punish" his Maker, + like those contemners of the gods, Ajax, Satan, Orestes, Don Jnan, $\ddagger$ Cain, $§$ Enperor Julian, whom the world admires and loves in secret. The influence of Byron's Satanism on Vigny's antitheism is obvious. But there is not in Vigny's attitude the slightest suspicion of pose. It is the natural, inevitable outcome of a system; it is not boastful and defiant, but sorrowful and calm. It finds expression, not in lurid imprecations, but in grave, and, strange to say, almost reverent words such as these: "If it be true that in the Sacred Garden of Scriptures-The Son of Man said that which is reported - Mute, blind, deaf to the cry of His creatures-If Heaven abandoned us like an abortive world-The just man will meet absence with disdain-And a cold silence will evermore be his reply-To the eternal silence of the Deity." " "

Thus all the works of Vigny, Cinq-Mars, Stello, Serritude and Grandeur of Military Life, like Moses, Chatterton or the Mount

* Un Dieu, Journal d'un Poete, 170 ; Cassandre, J.P., 265.

† J.P., 104. \$ Ibid., $93 . \quad$ \& Ibid., 166.

II Daphne, J.P., passim.

- Le Silence, postscript to Le Mont des Olivicrs. 


\section{FRENCH PROPHETS OF YESTERDAY}

of Olives, are indeed "the cantos of an epic poem on disillusionment." * One by one, all the old beliefs died in Vigny's heart, even the belief in a just and loving God. "The truth about life is despair." $\dagger$ In the midst of all these ruins, it seems impossible to find the elements of a living faith.

Epicureanism would seem the natural consequence of such thoroughgoing destructive criticism: but Vigny was never tempted by the cult of pleasure, be it high or low. A soldier and a gentleman, he had a substitute ready for the old discipline, now without force; and that was Honour. "Honour," he said, "is the only basis of his conduct, and saves him from crime, and from all forms of baseness : it is his religion," + "his God ever present in his heart." $\$$ Negatively it teaches him resignationnot the whining resignation of the weak, but the stoic pride of the dying wolf, the deep calm of the captain conquered by brute elements, the cold silence of the just man in answer to the eternal silence of God. Positively, it teaches him energy, the "accomplishment of our long and heavy task." There it stops: for this religion of honour, although less barren than the religion of despair, is neither rich and deep nor eren clear. This aspect of Vigny's philosophy has a sombre grandeur of its own, and has inspired some of his best-known lines; yet it should not be unduly emphasised. In the development of his thought this stage is but a provisional one, like the practical code of ethics which Descartes adopted before his system was fully elaborated. A world of such " men of honour" as Vigny describes would be very noble indeed, but cheerless and unprogressive. After all, what is honour? The nobleman's or the soldier's honour, which Vigny had probably in view, is a feeling of mreasoning loyalty to a leader or to a class - not incompatible with a certain looseness in other respects. Such an honour may be admirable in some of its manifestations; but if the leader happens to be a degenerate, a dotard, or a traitor, if the class has lost its raison d'etre, and is but a fossil in a democratic age, honour is a dangerous, narrow virtue, the sterile worship of prejudice. It was that mistaken sense of honour that impelled many noblemen to cross the frontier

$$
\begin{array}{ll}
* \text { J.P., } 77 . & \text { † Ibid., } 93 . \\
\ddagger \text { Ibid., 86. } & \text { \$ Ibid., } 94 .
\end{array}
$$


in 1792 , before their lives or vital interests were threatened, and offer their services to the enemies of their country. The crimes of certain officers in the Dreyfus case had their root, not in dishonour, but in that nefirious idolatry the "honour" of a race or caste. And how shifting and uncertain such "honour" is, even with its most fanatical devotees! Chateaubriand had prophesied, and unwittingly done his best to prepare, the Revolution of 1830 : his sense of honour obliged him to serve, in their exile, a family which he had helped dethrone and which he halfopenly despised. Vigny's honomr, after a velleity of action, was more easily satisfied-and who can blame him? Loyalty to objects unworthy of a man's allegiance may be an excusable error; it is not a virtue. Honour should cede before duty.

"Honour," Vigny said later, "is the poesy of duty." This is a wider and more beantiful definition. Not the soldier, not the aristocrat alone, but the humblest labourer may have his sense of honour, if he talies joy and pride in doing his duty. Honour, thus extended to all men, means loyalty, not to a class, but to mankind; not to a class leader, but to the universal leader, the Ideal.

Thus Vigny's sombre and hard stoicism, rooted in absolute pessimism, becomes, in the Shepherd's Cabin, a form of Humanitarianism. Our duty is not to ourselves-"renounce" is the first and last word of philosophy, the essential condition of "honour" ; not to blind nature; not to a silent God; it is to our kind, to our fellow-victims, to "the majesty of human sufferings," to "that which passes and is never seen again." And this duty, through an added touch of love and pity, is transmuted into "honour," into religion.

The universal leader, the Ideal, is Thought, our comforter and our guide. Descartes saw in thought the proof of existence; Pascal, the basis of our dignity; Vigny, their true disciple, wrote: "Let us find comfort for everything in the thought that we are enjoying our very Thought-a joy which nothing can take away from us." * "Thought can doubt all existence, except its own; it can deny all joy, except the joy of thinking. "The contemplation of suffering itself is for the soul the source of 
a secret joy, which comes from the soul's activity in the idea of suffering." * Thought is the mythical lance which heals the very wounds it has inflicted.

Honour bids us renounce and devote ourselves to unselfish service; mankind, suffering from the unjust sentence of an unknown power, is the worthiest object of our devotion; the quest of truth is the highest ideal and the surest comfort. All these different strands-religion of honour, of humanity, of thought-are combined in the religion of science, for science is the research of truth for the service of man. Vigny's last poems, the all-inclusive Shepherd's Cabin, The Bottle in the Sea, The Pure Spirit, are splendid hymus to science, the "divine elixir," the "queen of the world," whose reign has come at last. And the only true God is the God of Thought, in whose Word our spirits live and move, as our bodies in space.

Such was Vigny's final faith. We can discern in his spiritual make-up three elements-pessimism, stoicism, intellectualism. His pessimism was inborn-darkest, perhaps, when his life was happiest. His stoicism combined the gentleman's sense of honour, the soldier's idea of discipline, with the proud resignation of a Christian not uninfluenced by Port-Royal. His intellectualism was intense, passionate, and amounted to ideaworship; but he never was a blind devotee of reason reduced to logic or common sense, or of materialistic science. These three elements co-existed in him from the first, in the poems of 1823, and all are found in The Silence and The Pure Spirit, his swan-song. They are irreducible: to take any of the three as the single centre of Vigny's thought would be unfair to its rich complexity. No new essential element was added in the course of forty years; but Vigny's thought, although ever consistent, was not immovable. The interaction of the three main elements produced many combinations. Broadly speaking, we may say that his pessimism was uppermost in his earlier works, of which Moses may be accepted as the best tyje; his stoicism found its clearest expression in The Death of the Wolf (1843); whilst The Bottle in the Sea (1858) and The Pure Spirit (1863) embodied his faith in the "God of Ideas." 


\section{THE POETS OF SCIENCE AND DESPAIR 191}

And if that faith seems to us prond, austere, and cold, let us not forget that Vigny's pessimism, his stoicism, and his intellectualism were alike tempered with love and pity, that Divine pity which inspired his two longest poems, Eloa and The Shepherd's Cabin: pity for all suffering, pity for all that lives but a moment; pity eren for sin and for Satan-supreme guilt, therefore supreme misfortune--passionate pity which never sinks into sentimentality, but urges us to willing sacrifice. Gentleness is sweetest in the strong: the tenderness of Vigny's lines to Eva-the symbol of all our afllictions and aspirations-is all the more exquisite for the dark backgrome of his philosophy.

Alfied de Vigny left no direct disciples. In literature and in thought, as in real life, he remained isolated in his Ivory Tower.

Yet there is a strong temptation to make up a Vigny school of philosophical poetry with the names of Leconte de Lisle, Mme. Ackermann, Sully-Prudhomme, Jean Lahor. None of the recognised schools in French literature-Pleiad, Cénacle, or Parnassus-would offer such intellectual homogeneity. In all these poets we find the same rare elements as in Alfred de Vigny: loneliness and despair, reserve and stoic pride, learning and faith in science, and that unconquerable mystic yearning which, combined with inborn pessimism and modern scepticism, leads to antitheism rather than to irreligion.

\section{Leconte de Lisle.}

If by art we mean the constant and complete mastery of one's instrument, Leconte de Lisle was a greater artist than Vigny. There are blemishes in the finest marble, and we could point ont many a harsh line-perhaps intentional, many a weak one -withont apparent cxcuse-in his four volumes; but he remains, on the grand scale, what Gautier was in miniature: the faultless craftsman.

The perfection of his art, and his own absolute faith in the conceptions which it cmbodied, gave him in his lifetime a degree of fame and influence which Vigny never enjoyed. His name reached but slowly the general public, with whom he never 
became popular; but among poets he was supreme. Within his narrower field he was even more absolute a ruler than "the Father in exile." Hugo was the god, but Leconte de Lisle was the high priest, the more potent of the two.

It was Leconte de Lisle's art that won for him, among the poets of his generation, the uncontested monarchy of wit. Yet not his art alone. As an apostle of Art for Art's sake, Théophile Gautier was first in the field (Mlle. de Maupin, 1835), and his Emaux et Camées, published one year before the Poèmes Antiques, gave both the precept and the model of flawless workmanship. Théodore de Banville, whose first poems came out some ten years before Leconte de Lisle's, was the most thoroughgoing exponent of the doctrine, and the modern "Legislator of Parnassus." But Gautier and Banville were amiable epicures, and even in a frivolous age leadership seldom falls to any but earnest men. The Second Empire was not all noise and glitter: it was a time of scientific investigation and religious conflict. The head of the Parnassian school was no mere rhymester, but the contemporary of Taine and Renan, a scholar, a historian, a philosopher. We had to make this point clear, because among the many "cults" and substitutes for religion which were tried in the nineteenth century, Art for Art's sake was one of the most assertive, and spiritually the most barren. The worship of form led absolutely nowhere. If Leconte de Lisle commands our respectful attention, it is not because of the marmorean splendour of his poetry, but because of its message. Who would not prefer to see noble thoughts always clothed in beautiful words? But a religion whose first article of faith is: "I believe in rare and sonorous rhymes," and whose prayers end with: "Deliver us from double genitives!" cannot expect to be taken very seriously.*

Leconte de Lisle tried to introduce historical rigour into imaginative literature. The Romanticists had made a similar attempt under the influence of Walter Scott, among others:

* Be it understood that what we say of Art for Art's sake as a religion need not apply to Art for Art's sake as an esthetic doctrine: the autonomy of art is a defensible cause. Also, that Art for Art's sake is not quite the same thing as \#stheticism (cf. Baudelaire), or the cult of bcauty (cf. Renan). 


\section{THE POETS OF SCIENCE AND DESPAIR 193}

Hugo, Vigny, the elder Dumas took no little pride in the scrupulous accuracy of their information.* But they were untrained and full of passion. Romantic history became a gorgeous masquerade. All characters, ancient, medieval and modern, were self-portraits of symbols: Moses and Chatterton are Vigny himself; Antony and Hernani are twin brothers.

With such a travesty of truth Leconte de Lisle had little patience. The poet of a scientific age must, then, be disinterested and impassible. All teaching and preaching, any obtrusion of his own personality, are out of place in his work. Objective, "positive" truth is his only goal. Not only the material details of the events he relates will be more definite and more accurate than in the poems of his predecessors, the Romanticists, but he will be infinitely more respectful than they of psychological and spiritual truth. Such, at least, are his claims: if they were justified, all his poems on Hindu, Greek, Norse, Hebrew, and Christian myths, legends, and episodes would tell us nothing about their author; they would be a gallery of historical pictures without any bearing on the religious thought of our time, and this part of our work would remain unwritten.

But although Leconte de Lisle aspired to scientific impassibility, he was bound to fail in the attempt, as he was a genuine and a great poet. His personality, theoretically banished from his productions, is seen almost everywhere in them, and the parts from which it is absent are already dead, if they may be said ever to have lived. He reveals himself through the very selection of his subjects; many of his poems deal with religious themes-we find everywhere evidence that the men of that time were more vitally interested in such questions than we are at the present day. Be they never so varied from the historical and geographical points of view, these poems have an essential unity of spirit: they are almost uniformly hard and sombre. We had almost said a unity of purpose-few are those that do not teach the doctrines of despair. In this respect even the omissions of Leconte de Lisle are instructive: when translating ÆEschylus's trilogy, the Oresteia, he could not bring himself to include the third part, the Eumenides, which represents atonement, for-

\section{* Cf, Hugo's prefaces to Marie Tudor and Ruy Blas.}




\section{FRENCH PROPHETS OF YESTERDAY}

giveness, and peace. His boasted impassibility does not keep him from anathematising the Middle Ages in general, and the Catholic Church more particularly, with a concentrated vehemence by no means "scientific":-

"In every one of your execrable minutes, $\mathrm{O}$ centuries of murderers, cowarås, and brutes, The shame of this ancient globe and of humanity, Cursed be ye, cursed, for all eternity." *

Nay, in some of his most striking poems Leconte de Lisle did the very thing for which he so haughtily rebuked Alfred de Vigny: he selected a historical or a legendary character, and used him as a mouthpiece or a symbol; he placed a purely modern subject in an archæological setting, and the thoughts of a nineteenth-century "anti-clerical" on antediluvian lips. The result may be admirable, but the author of Qaïn has no right to reprove the anthor of Moses.

Leconte de Lisle was a man of intense feelings; there is even a tender note-all too rare, but exquisite-in such poems as Le Manchy and Le Frais Matin; the very sonnet in which he deprecates self-revelation (Les Montreurs) is full of irrepressible passion. There was a man behind that cold, glittering mask of art and science: and that man was not a Hindu ascetic, nor yet an ancient Greek, as he would have us believe at times, but one of us, intensely modern in his thoughts and feelings, with all the doubts, the bitternesses, and the enthusiasms of his time and of his race-the younger brother of Leopardi, Vigny, and Schopenhauer.

Pessimism is the keynote of Leconte de Lisle's philosophy: a pessimism less systematic perhaps than Alfred de Vigny's, but more violently passionate and more incurable. In some of the Poèmes Antiques there still are gleams of hope: Nature is still able to comfort and to cheer :-

\footnotetext{
"O sea, O dreamy woods, pious voices of the world, You have answered me during my evil days;

You have appeased my barren melancholy, And you sing eternally in my heart." $\dagger$
}

* Les Siecles Maudits, Poèmes Tragiques.

† Poimes Antiques, "Nox." 


\section{THE POETS OF SCIENCE AND DESPAIR 195}

Yet that faith in nature is soon discarded as an illusion : "Nothing answers in boundless space but the sterile echo of our eternal desire." " Nature makes sport of human sufferings," he said after Vigny.t "She is naught but an illusion and a snare." + Nature is indifferent: mankind is worse. The splendour of antiquity has vanished for ever; the poet despises the modern world for its cowardice and its avarice, for its aimlessness and its corruption. $\S$ Life is a burden, and the dead should be envied, "for they are liberated from life, and no longer know-the shame of thinking and the horror of being men!"

For such miversal misery, who can be responsible but the Maker of all things? No radical pessimist-Leconte de Lisle no more than Vigny or Mme. Ackermann-can escape antitheism : the omnipotent ruler of an evil world must himself be evil. Centuries of gloomy Christianity, condemning life, beauty, joy, distrusting or despising nature, preaching eternal suffering as an integral part of the miversal scheme, had made such it conclusion inevitable. The God who is a loving Father only to the "small number of the elect," and has doomed the majority of the race to everlasting pumishment for a crime not their ownsuch a God, in modern eyes, is a monstrous idol. Vigny had formulated this verdict in his quiet, dignified, and final mannor : the silence of the just is an irrevocable condemmation. Leconte de Lisle expanded and symbolised it in his masterpiece, the sombre and grandiose poem, Qaïn.

The murderer, rising from his sleep of ten centuries, answers the angel of the Lord:-

"Did I create life and evil?

Said I unto the inert clay: 'Suffer and weep'?

Have I created with the ban the longing,

The burning thirst of unattainable good

And the deathless dream in ever-dying time?

"Poines Antiques, "Dies Iræ."

† Poemes Barbares, "La Fontaine aux Lianes."

† Ravine Saint-Gilles.

$\S$ "Aux Modernes."

"Po'mes Tragiques, "A un Poète mort."

- Translated by F. P. Anderson. 


\section{FRENCH PROPHETS OF YESTERDAY}

Bidan the will and punished the fulfilment?

Oh misery! Did I sar to the implacable Master.

The jealous God. thrmentor of the world and of the living,

Who chides in the tinunder and rides upon the winds:

- Surely life is good! I rould fain be born!"

What iras life to me at the price Thou exactest for it?"

Yes, God is responsible, and we, His rictims, should not cringe and farm before the Tyrant, but confess to His face our indomitable belief in justice, greater than $\mathrm{He}$ :-

“I shall remain erect! And from eve to rnorn

And from darn to dusk nerer shall I still

The tireless ery of a despairing heart!

The thirst for Tustice. O Cherub! derours me.

Crusb me: else I shall neter yield."

The Creator repenteth Himself, thus confessing that His work was not good. The Flood will annihilate the world. But Cain, the riction and the arenger. will not hare it so. The creation of man Tas God's crime: let it be His curse! The murderer, roieing the spirit of eternal justice in rebellion against fate and caprice. will sare mantind. The Ark is built, the Deluge will be in rain. And the Tormentor will finally be exorcised from His creation :-

. And God, jealous God, who hidest Thy face,

Who diast lie. when Thou saidst Thy work was good,

Mr breath. O Fneader of the ancient clay,

Cne dar shall exali Thy living rictim.

Thou shalt say to hin: Adore! He will answer: No!

From hour to hour. Jehorah! his mutinied strength

Shall loose the grasp of Thine arm,

And flinging down Thy yoke as a vile bond,

The things created, free in conquered space,

Will no more hearken when Thou speakest to them.

To bring to naught the rorld that denies Thee,

Thou shalt cruse blood to How like a sea,

Shackles of iron to bite decp into flesh.

In the endless horror thou shalt cause to flare

The gulf of Hell beside the shrieking pyres.

But when Thy priests. iron-jawed wolves,

Glutted with human Hesh and thin with rage,

Shall seet the guerdon of the offered holocaust,

Rising before them from the ashes of the just, 


\section{THE POETS OF SCIENCE AND DESPAIR $19 i$}

I will scourge them with immortal scorn,

And the litile children of the arenged nation,

Fnoring Th: name no more, shall laugh in ineir cradles.

I will tear down the sill: rault of Hearen.

And he who seets Thee there shall find Thee not, And tha: shall be m: day! And from star to star,

The happy Eden long rezretted

Shall see doel risen and sheltered upon my heart;

And Thou, dead and aern up in the burial shroud,

Shals tall aray to destruction in Thy barrezpess."

Perhaps fer Anglo. Sazon readers would read Cain to the end. The srmbol which the poet adopted would be to them unspeakably offensire. Tet Cain is no sensational and insincere blasphemr of the Baudelaire-Richepin trpe: it is eren free from the element of defiance, the desire of puzzling and horrifying the Philistines, which detracts from the spiritual importance of Proudhon's explosive parador: "God is Eril." Cain is the passionate cry of a soul that hungers and thirsts after righteousness. Nowhere does Leconte de Lisle's admirable rerse gire such a true religious ring. Leconte de Lisle spurned the precalition that Vigny, who had thought of a sinilar subject. noted in his Diary: "Place the scene in a Pagan setting." Instead of "Iahreh," let us read "Jupiter," and the piece, in it Eschy. lean grandeur, will be unimpeachable. But, for whoever considers the first chapters in Genesis as nothing more than an Oriental legend, the use of the mrth is perfectly legitimate, and has no sacrilegious intent. A second objection mar be raised against the smmbolical ralue of the poem. Leconte de Lisle is risibly attacking, not God Himself, if by God we mean supreme Justice and Truth, but a certain conception of God, responsible fur the "gloom and horror" of many centuries, and now more and more openly discarded eren by consertative belieters. If it be so, if it be nothing but a phantom, a creation of primitire and diseased brains, a theological nightmare, that he is aiming at, is not his tragic earnestness out of proportion with the end in riew? In such a case we think that the old Stendhalian gibe would hare been sufficient: "God's (that god"s) only excuse is that he does not exist." If the God meant in Cain is real, then the poem is not so much sacrilegious as nonsensical, for we 


\section{FRENCH PROPHETS OF YESTERDAY}

cannot conceive of a God morally inferior to His creatures, and ceasing to exist as the result of their denying Him. If that God is merely an idea, then all that righteous indignation is wasted. In fact, the word God here means both a reality and a mere notion. It stands for the awful mystery of creation, with its elements of $\sin$ and pain, the curse that undeniably has lain heavy upon mankind since the world began, the seeming contradiction between our sense of justice and the facts of this universe. This Power, unknown in its essence, all too real in its manifestation, is that against which man's highest instinets bid him fight. To call such a Power God is a blasphemy; but for this blasphemy Leconte de Lisle is not responsible. It is wellmeaning believers who with their monstrous schemes have made God identical with the creator of evil. The golden age prophesied by the poet will see at the same time the laying down of a fearful spectre that hindered progress, and, through man's efforts, the filing away, the falling apart, of material shackles-sin, misery, ignorance, and disease. It will be the reign of science and of brotherly love, the kingdom of the true God.

Cain is supreme and almost unique among the works of Leconte de Lisle, because it preaches action and offers a prospect of hope. The evil principle, the God of theologians, will finally be conquered. Unhappily, this is only a passing gleam in Leconte de Lisle's sombre horizon. He does not belong to the greater pessimists, to the "twice-born souls" who, through thought, action, or faith, overcome their own despair. More extreme than Vigny in the expression of his distress, he does not rise to Vigny's active and tender stoicism, still less to his ultimate faith in " the God of ideas." We miss the exquisite sympathy and pity of The Shepherd's Cabin, the lofty spirit of service of The Bottle in the Sea.

Leconte de Lisle is a misanthropist as well as an antitheist and a contemner of Nature. Such a position is illogical. If God be evil, then we ought to love, pity, and help man, his irresponsible victim. If we despise Nature's indifference, then we should bow to the supremacy of human thought and "the majesty of human suffering." Leconte de Lisle's haughty 


\section{THE POETS OF SCIENCE AND DESPAIR}

stoicism is impressive, but narrow and selfish. Love of art and love of science, apart from love of man, cannot be a rule of conduct. If the poet writes beautiful lines, if the scientist gathers curious facts, not for the enjoyment or betterment of their fellow-creatures, but for the satisfaction of their own pride, what are they but refined egoists? We know full well that Leconte de Lisle was not such. Had he not laboured in the field as a patriot, as a Republican, as a free-thinker,* he would still be amply justified by the ennobling influence of his poetical work. But we cannot all be supreme artists, and there are more pressing duties than polishing precious words while expressing intensest scorn for "the carnivorous rabble" of our fellow-men.

Pessimism and its concomitants are all negative. On the positive side of Leconte de Lisle's philosophy we find-nothing. Systematically nothing. He borrowed from Hinduism the notion of universal illusion ending in universal nirvana.t $I$ am afraid that his French readers, maccustomed to such grandiose and hazy metaphysical dreams, saw little more in them than inexhaustible poetical themes. The piece-

"The secret of life lies in closed tombs:

That which no longer is, is such only because it has been, And the final annihilation of beings and matter Is the only reason of their reality,"

with its elaborate technique and its abysmal depths of non-sense, seemed to the average French mind an excellent, transcendental joke, all the better for its being so solemn in tone.

After all, Alexandre Dumas fils voiced the wholesome sentiment of the race when, taunting Leconte de Lisle with his eternal aspiration to the "impassible peace of the dead," that peace "which life has troubled," he asked him whether such peace was not within his reach. One wonders what call such a radical contemner of life had to be alive. A pessimistic philosophy, replies M.Jules Lemaitre, does not lead to suicide, because we rise superior to our ills and woes by the very act of compre-

* Cf. his poems, A l'Italie, Le Soir d'une bataille, Le Sacre de Paris ; his Catéchisme Populaire Républicain ; his Petite Histoire du Christianisme.

† La Maya, Poßmes Tragiques. 
hending them. Such a feeling of superiority is in itself a source of pride, of peace, of joy. True. Vigny had made that discovery long before, and that one positive element--the joy of thinking, even about our misery-gradually softened and almost absorbed his pessimism. It is probable, as Lemaitre surmises, that Leconte de Lisle derived much pleasure from his gloomy view of life. Like the valetudinarian old lady, "he enjoyed poor [spiritual] health." But, afraid perhaps of marring the sombre unity of his works, he tried to keep that pleasure a secret. If such be the case, Leconte de Lisle's pessimism is either a fraud or at least a form of sentimentalism not more admirable than René's. Hence the feeling of incompleteness, of onesidedness, which the four volumes of Leconte de Lisle leave with us. We see the man behind the glittering verse-else he would not be such a poet-but we do not see the whole man, nor perhaps the best there is in him. Imagination, passion, learning, unrivalled skill were his, yet something stiffens all his gifts and repels our sympathy: whether coldness of heart or narrowness of soul we cannot tell. 


\section{CHAPTER III}

\section{CRITICS AND HISTORIANS: SAINTE-BEUVE, TAINE *}

\section{Sainte-Beure.}

Aften 1848, the age of spiritual adventures was over for SainteBeuve. He had studied, tried, and abandoned everything. The Cénacle and its Romantic religiosity, Saint-Simonism, Lamennais's liberal Catholicism, Vinet's Protestantism, the Jansenism of Saint-Cyran and de Sacy, had successively appealed to his insatiable curiosity. At times, the Voltairians and the Eclecticists-Béranger, Thiers, Cousin-might think he was one of themselves; but he also did homage to Chateaubriand at his littlo court of L'Abbaye-aux-Bois, and gave hopes even to Mme. Swetchine, de Maistre's convert and Lacordaire's adviser. He had been in every case a most promising

* Scheror rightly bolongs to this group of Positivists : at the end of his long and painful evolution he was the most thoroughgoing relativist of them all. (Cf. L'Illusion Metaphysique, Etudes sur la Litterature Contemporaine, iii.) We give him no place in this chapter, because, while he was a close reasoner, an excellent scholar, and a brilliant writer, he showed, in this second part of his career, no commanding originality. Admired and respected, he had no distinct traceable influence. Bishop Dupanloup, in his Avertissement, 1863, in his L'Athéisme et le Péril social, 1866, denounced the erudite but modest scholar, Alfred Naury, along with Littré, Renan, and Taine. But this excellent specialist does not belong to us. Victor Duruy, the historian of Rome, the great Minister of Public Education, also bitterly attacked by the "Cloricals," was in full sympathy with this group of men, although his position in a repressive Government was a difficult one, and, but for the enlightened protection of the Emperor, would have been untenable. Cf. his Notes et Souvenirs, ch. iii.-MIon Examen de Conscience; ch. xiii., Rapports avec le Clergé. Havet should be mentioned as occupying a middle ground between the reverent historians of religions like Ronan and the bitter critics of the Voltairian typo. 
catechumen, willing, earnest, and supremely intelligent. Ever on the eve of taking the decisive step, he would ever disappoint the expectations of his friends, and pass on to a new experience. Of all men, he was the most unstable, the most elusive and slippery; his mind was a kaleidoscope or a series of dissolving views, and himself, according to his admirers, a Proteus-a chameleon according to his detractors. Sincere withal, in his own undefinable way; disinterested in his evolutions; apparently striving for the highest; a confessed and confirmed deserter, and yet, in this respect at least, not despicable.

Henceforth, he would no longer roam: the quest was at an end. "I have much played and much dreamed in my life," he said. "Now that I am nearing the term, I think." *

This defines, at least negatively, the religious attitude of his last twenty years: he was not an emotionalist, not a mystic, and not a believer in traditional authority: he was a thinker pure and simple, a free-thinker. But free-thought is a Church with innumerable sects, from the blank nihilism of Mérimée to the quasi-Protestantism of Quinet. At the time of his death, Sainte-Beuve was one of the pontiffs of scientific materialism; but that was a late development, and not wholly spontaneous. His mind was too subtle and too mobile to be permanently satisfied with the most rigid and narrowest of all creeds. There are no more metamorphoses in SainteBeuve from 1848 to 1869 ; but there is a constant evolution and the old many-sidedness has not disappeared.

The outward changes in Sainte-Beuve's religious attitude were partly the manifestation of this inner development, partly the result of political conditions. Few indeed were the French men of note in the nineteenth century whose formal religion was not affected, or even controlled, by secular considerations. The Church was a party, at least a social tendency; every party, on the other hand, had its ideal and its creed, its mysticism and its orthodoxy, like a sect. Such a condition will seem monstrous to readers unfamiliar with conditions 
on the Continent, or with the history of their own race: we act on the belief that the individual soul and the State should be governed on totally different principles. But many earnest men in the past were not able thus to lieep separate the believer and the citizen within themselves: to Jesuit, Covenanter, and Socialist alike, religion and polities are one.

This of course applies to Sainte-Beuve only in a limited degree, for he was the reverse of a fanatic. But his attitude was much more decided and consistent in polities than in religion, although he never was, strictly speaking, a party man. A son of the lower bourgeoisie, closer to the people than to the aristocracy, he har the two ruling passions of his class. He loved equality - that is to say that he hated privilege and was impatient of any assumed superiority-and he loved order, which was congenial to his industrious and somewhat unheroic nature. Thus he was a democrat, but neither a liberal in the doctrinaire sense, nor a demagogue.

A warm supporter of the opposition under Charles X., he applauded the Revolution of 1830, but preserved his independence under Louis-Philippe. The new aristocracy of wealth which ruled cynically under the Citizen-King was more obnoxious to him than the dethroned aristocracy of blood, and the assumption of infallibility quite as intolerable in Guizot as in Polignae. The fall of Louis-Philippe in February, 1848, did not therefore cause him any regrets. But neither did the new Republic, with its splendid promises, fill him with enthusiusm. He was no longer a Romanticist, but a cool, sceptical critic. Ho was a middle-aged bourgeois, somewhat sluggish and timorous, * who, suddenly disturbed in his habits of life, cursed between his teeth that unwarrantable intrusion of the ideal. Like a large number of his compatriots, disgusted with Legitimists, Orleanists and Revolutionists alike, he began to look upon Louis-Napoleon as the possible saviour of society. In 1849, when he came back from his year's lecturing at Liége, he began the wonderful series of his Monday T'allis (Causeries du Lundi)

* That he showed any cowardice in those days is pure slander on the part of Louis Veuillot. He did not leave Paris for Liége until October, 1848, when all danger was over. 


\section{FRENCH PROPHETS OF YESTERDAY}

in Le Constitutionnel, a paper of Bonapartist tendencies.* Three years later, after the Coup d'Etat, on the eve of the Empire, his famous article Regrets, aimed at the OrleanistLiberal coalition, stamped him as an unhesitating supporter of the new regime. The article, biting and wonderfully keen, was perhaps ungenerous at the time. But to ascribe SainteBeuve's evolution to mere spite, or fear, or selfish interest, is partisan nonsense. A critic, a man of quiet and fastidious social tastes, who, with his eyes open, breaks with the ruling coterie in the Academy, with the University, with the salons, and with the literary Press, is certainly no selfseeker.

Sainte-Beuve thus became a semi-official journalist of the Empire, and as in those years Napoleon III. was hailed by the Church as a new Constantine, another Theodosius, the critic was exceedingly careful not to offend Catholic susceptibilities. All chances of conversion were over for him: the tone of the last two volumes of his Port-Royal left no doubt abont that. But his references to Christianity were always reverent; Catholic subjects were treated with broad sympathy; there was a note of melancholy, almost of despair, in the closing lines of Port-Royal, which has a decided religious ring.

But after the Italian war of 1859 , when the Ultramontanes broke with the Empire, Sainte-Beuve was free to follow his natural tendency, which would lead him farther and farther away from the Church. The New Monday Talks (Nouvelles Causeries du Lundi), which appeared in Le Constitutionnel from 1861 on, were bolder than the first. They opened with an onslaught on de Laprade, the poet laureate of the CatholicLiberal opposition [September, 1861] ; a long and feline study of a "Mother of the Church," as he dubbed Mme. Swetchine, soon followed [November, 1861]. The fine article on "Father Lacordaire and Four Religious Moments in the Nineteenth Century " (March, 1863), the warm tribute to Littre at the time of his conflict with Mgr. Dupanloup (June-July, 1863), the favourable review of Renan's Life of Jesus (September, 1863), were unequivocal in tone and purpose: Sainte-Beuve, the prudent, shifty Sainte-Beuve, had boldly stepped into the arena.

* And after 1852 in Le Moniteur, the official organ of the Government. 
In 1865 he was made a member of the Imperial Senate, the most conservative political body that France has ever known. But his new dignity failed to check his now rapid evolution. It would be excessive to say that, almost as soon as he became a Senator, he threw himself into the opposition : ${ }^{*}$ there is no such marked difference between his articles of 1864 and his articles of 1866. But his high position and the piquant contrast between the opinions of his colleagues and his own gave additional weight to his words; whilst under the influence of age, independence, authority, with a sense of an impending crisis for his country and, for himself, unmistakable warnings of approaching death, he was growing more and more radical and assertive. In his speech of May 19, 1868, in reply to the Bishops in the Senate, he stood for his "own diocese," that of common sense, free-thought, and science; he assumed the position, not merely of a combatant, but of a leader.

During these few years of militancy Sainte-Beuve tasted genuine popularity for the first time in his life; to what extent he courted this popularity, what influence it had on his evolution, is not easy for us to ascertain. There was a noticeable difference in his style, which became every year less subtle, less involved, more direct, and more forcible: it does not appear that his essential beliefs were materially affected thereby.

Political conditions had thus made Sainte-Beuve one of the high priests of anti-clericalism and free-thought. A curious avatar, no doubt, for the agile and many-sided critic, whose mind seemed to grow more active and broader with advancing years! But behind the outward evolution we have to trace another, more gradual, deeper, more complex, parallel with the first only to a certain extent. The author of Port-Royal never became a mere Voltairian scoffer or a psendo-scientific materialist.

His mighty work, Port-Royal, took twenty-five years of his life (1834-59), and remains one of the great religious books of the nineteenth century. Religion, it is true, was not its arowed or its primary subject. Sainte-Beuve wanted to study, with Port-Royal as a centre, the whole literature of the classical age;

* Professor G. M. Harper, Sainte-Bewve, p. 349. 
and, especially after the climax, the chapters on Pascal-social history, with innumerable digressions, anecdotes and portraitswas an important part of his scheme. Yet, if Sainte-Beure had been prompted exclusively by intellectual curiosity, he would have spent less time on the Jansenists. There were many other attractive fields, either richer, or more popular, or more picturesque. But for Pascal and for the spiritual significance of Port-Royal, the annals of the community would be dreary. Sainte-Beuve, without ever forgetting his main purpose and his special qualifications, which were of a literary nature, did full justice to the religious import of his subject. He himself studied extensively, dived into recondite theological works, and displayed this unexpected learning, especially in the first two volumes, with a complacency dangerously akin to pedantry. But more important for our purpose than all theological lore is the central problem of the book-the drama of the author's life, of many men's lives, the duel between the "natural man" and the Christian, the sceptic and the believer, Montaigne and Pascal.

That this debate was not for Sainte-Benve merely an academic one can hardly be doubted. Yet he attempted later to cover his traces, and made light of his several religious "excursions." "I nibbled at the bait," he said, "but escaped the trap." And he would have us believe that eighteenth-century materialism, "in all its crudity," was from the first the true foundation of his philosophy. The evidence of his own writings is more convincing than his denegations. There is in Port-Royal more than historical insight and impartiality; more than the rsthetic sentimentalism which he may have learnt from his friends of the Cénacle; more, also, than the turbid sensuous religiosity which, it is said, his mlawful passion fostered in him : there is a depth and an earnestness which personal experience alone can give. Pascal and Montaigne were indeed fighting for his soul.

Sainte-Beuve, materialist though he was, had a keen sense of a duality in himself. He was a strange assemblage of a wonderful intellect, strong and pitilessly clear, with a physical nature brutal enough to degrade him in his own eyes, not strong enough to rule him entirely and to intoxicate him with the animal joy of living. 'Thus he had, more than better men, the essential 
Christian experience : the consciousness of the fall, the "conviction of sin," the sentiment of the total depravity of man. He was a divided self, the angel and the beast at war within him, and the angel, too often worsted, greatly needing some aid from above, the saving grace of God.* In all modern French history, the men who had most radically condemned the natural man, most exclusively relied on the grace of God, were the Jansenists. Sainte-Benve did not write his five volumes for the sole purpose of debating in his own mind the eternal question: Nature or grace? But this question, with its immediate bearing on his own destiny, coloured the best parts of his work.

Although Port-Royal was not completed until 1859, the struggle was over before 1848: Sainte-Beuve was not a believer. Was he ever, in the words of Vinet, "convinced, but not converted," persuaded of the truth of Christianity, but prevented by his lower nature from professing the truth he knew? It seems that exactly the reverse would be more probable: Sainte-Benve was, theoretically at least, more converted than convinced. He wanted a belief, a doctrine, a discipline which would give his life unity and dignity : his lower nature was willing to be subdued, but his critical intellect prevented him from accepting the solution offered by Jansenism and Calvinism. That solution seemed to him historically baseless, philosophically arbitrary. In practice, it had inspired noble but one-sided lives, and led to monstrous excesses, to harshness and self-mutilation. The radical condemnation of the " natural man" would lead us back to the exaltation of monasticism, disease, and insanity. $\dagger$

The opposite view is absolute optimism, the belief in the goodness of man and Nature, the joyous, large-hearted pantheistic naturalism of Rabelais, or, in our own days, Utopian Socialism, idyllic anarchism, the humanitarian faith of the Romanticists. Sainte-Beuve had been one of the heralds, if not

* In this he was not unlike Victor Hugo: but Hugo, a better man on the whole, less introspective, more active, easily self-satisficd, took refuge in his immense pride, substituted contrast for conflict, and found it an effective literary device.

† We are inclined to believe with M. d'Haussonville that, far from convincing him, his controversy with the Lausanne Protestants finally ruined his faith. 
one of the protagonists, of Romanticism; he was to a certain extent a democrat, perhaps even a socialist: he hailed Napoleon III. as a "Saint-Simon on horseback." But when Christianity had become impossible for him, he did not go over to the other side. He was too clear-sighted, too critical, to share in the illusions of a group of men which he had abandoned ten years before; his native pessimism as to human nature was only growing deeper with age, experience, and the spectacle of social convulsions. Thus, cut adrift from Supernaturalism and $\mathrm{Na}$ turalism alike, Sainte-Beuve was left alone, without pilot or star.

What his formal attitude towards religion was during these years of transition (1848-59), we have already seen: it was non-committal, respectful, on the whole sympathetic. In the absence of any commanding faith of his own, he had to be content with substitutes and make-shifts. One of these was "la religion des homnêtes gens," a code of morals based on honour, common sense, moderation, good taste, the "religion," if the term will hold, of Montaigne, Molière, Lafontaine, Voltaire, on their ordinary level. This philosophy, which found its best expression in the famous litany: "Aimer Molière..."* is very different from Pantheistic naturalism. It is saner, quieter, but more commonplace; safer, but less generous, less optimistic. It is the attitude of middle-aged men who know life too well, and have neither fear nor hope. Not to be a dupe, not to be a bore, such is the beginning and the end of wisdom. This does tolerably well for "d'honnêtes gens"--sane, healthy, moderate, educated, well-to-do people, so long as circumstances remain normal. But for saint, sinner, or poet, such a "religion" is not even a philosophy: it is a blank.

On a higher plane, both metaphysically and spiritually, was the absolute scepticism which Sainte-Beuve professed at intervals during the same years. Although the answer is only Montaigne's "Que sçais-je?" at least the great question is asked. Sometimes this scepticism was self-satisfied, almost joyous: moral happiness, he says, can be conceived under three forms: Plato on Cape Sunium, Lucretius or Epicurus, St. Paul or Jesus. "A fourth form, scepticism, which understands everything, which

\footnotetext{
* Nouveaux Lundis, v.
} 
transforms itself successively into every one, and which conceives human thought as dreaming everything and as creating the object of its dream: Montaigne, Hume."* Montaigne had decidedly conquered Pascal.

Scepticism often leads to intellectual apathy: Sainte-Beuve's was of a different order. It served admirably lis ruling passion, Curiosity - the only master or mistress to whom he remained faithful unto death. Just as, with Chateanbriand, pride was the man himself, and assumed all forms, from virtue to silliness, $\dagger$ curiosity with Sainte-Beuve was his very nature, and ranged from scandal and gossip to mystic yearnings. For a long time, it was purely Epicurean : "fond of the rarest hidden flowers, he wished to gather the secret and deep poetry which they gave forth." $\ddagger$ Gradually, it became more intellectual ; his ideal was no longer to feel in order to enjoy, but primarily to understand, his mind remaining "free, serene, cold, impartial." Yet this is merely a substitution of judicial for dramatic dilettantism : pleasure remains the goal. But, with the long years of study, the early charm vanished; the severer joy of knowing and understanding was itself exhansted; now curiosity ceased to be selfish. It became a virtue-the love of truth, the scientific spirit. "It seemed to me that, failing the poetical flame which gives colour, but deceives, there was no more legitimate and honourable employment for the mind than to see things and men as they are and to express them as one sees them, to describe, all round one's self, as a servant of science, the varieties of the species, the diverse forms of human organisation, whose moral aspects are strangely modified in society and in the artificial maze of doctrines." "You [Jansenists] were continually speaking of truth, and you sacrificed everything to that which appeared to you under that name: I have been in my own way a servant of truth, as far as I could reach it." §

But what is Truth? The new devotee of Science is still a sceptic ; his latest idol is as hollow as any, and the last words are discouragement and disgust. "How limited is our sight! How short its range!. . . How much like a flickering torch

- Causerics du Lundi, xi. 515, Notes and Thoughts. † G. Lanson.

$\ddagger$ Port-Royal.

$\$$ Ibid., Conclusion. 


\section{FRENCH PROPHETS OF YESTERDAY}

lighted for an instant in the midst of boundless night!... How powerless one feels ... when the goal is reached ... when we discover in our turn that we are but a most, fleeting illusion within the infinite Illusion !" * There is earnestness in these words of despair; there is a longing for eternal truth; the Epicurean scepticism of Montaigne is left behind.

Joy and confidence were slow in coming. In 1863, in reply to Guizot's Meditations, Sainte-Beuve gave us, in the portrait of a pure scientist, philosopher, or critic, partly his confession, partly his ideal. Modest and patient, the critic is a sceptic, that is to say not one who doubts, but one who examines. He will never know what he most ardently wishes to know: new discoveries will give rise to new questions; the last word will ever be a secret. He knows that destruction is a perpetual law and condition of life, of its growth and progress; he knows that Nature is hard and pitiless; that most men are at the mercy of their impressions, and are changed by time, circumstances, and interests; that annihilation and oblivion are our destiny here below; that all promises of eternal life are but the echo of our own desires. He knows his limitations, and how little he has to offer to hungry and thirsty men. He has no "good news," as men understand it, to bring them; he pursues in his solitude high but imperfect truths which have no price but in and for themselves, and for the use of very few. . . . "Such a scientist is therefore neither threatening nor tempting; he even is, if you like, a living proof of the insufficiency and of the moral indigence of science. I abandon him, incomplete and bare as he is, to the believer's, happier than he." Not an ignoble ideal, to be sure ; but hardly a cheerful one.

But if believers may be happier than free-thinkers, they are not better, according to Sainte-Beuve. Here we come to the exact reverse of the Hedonism which had pervaded his philosophy for so many years. We must follow, not the doctrine which offers comfort and hope-in other words spiritual pleasure-but the one which, harsh or not, seems truest. "We are no longer free. Whether we mourn or rejoice over it, faith is gone; science, whatever may be said, is ruining it; for all vigorous and sensible

\section{* Port-Royal, Conclusion.}


minds, brought up on history, armed with criticism, studying natural science, it is no longer possible to believe in the old legends and the old Bibles. In this crisis, there is only one thing for us to do, if we will not languish and stagnate into decay : to pass on quickly, to march firmly, towards an order of ideas which are reasonable, probable, consistent, which give convictions if not beliefs, and whilst leaving full liberty and security to what still survives of the old creeds, to prepare in all the young and robust minds a basis for the future. Slowly a new morality and a new justice are being evolved, on a new foundation, no less firm than in the past, even firmer, for the puerile fears of childhood will have no place therein. We are men and women : let us, as soon as possible, put childish things away. It will be difficult for many women, you will say-for many men too. But in the present state of society, the salvation and virility of the nation depend exclusively on such an effort. We shall have to choose between Byzantinism and true progress." And we must also quote these few words to the students of the Paris Medical School : "I have held for a long time that the sole guarantee of the future, of a future of progress, vigour, and honour for our nation, was study, and especially the study of natural sciences, of physics, chemistry, and physiology. Thus many vague and false ideas will be cleared up or rectified: thus in the near future many futile or dangerous questions will gradually, imperceptibly, be deprived of their importance, and, who knows? be finally eliminated. Not only the physical hygiene of mankind will be the gainer, but its moral hygiene as well. In this respect, much remains to be done. Study, work, gentlemen, and help to heal some day our sick in mind and body" (May, 1868).

These words may fall short of our spiritual ideal; but there is no doubt as to their earnestness, their directness, their moral dignity. There is in them a quiet reserve of strength which implies a firmer and a more definite faith than Sainte-Beuve openly professed. We have here the religion of science, stripped of all romantic exaggeration, expressed in terms of quasi-scientific simplicity.

This progress in Sainte-Beuve from Epicurean scepticism to. 


\section{FRENCH PROPHETS OF YESTERDAY}

scientific stoicism atoned for many weaknesses in his earlier life, and explained, almost justified, the words of reverent admiration which, when the critic died, Amiel, a keen observer and a man of fine spiritual instincts, wrote in his journal: "October 16, 1869 : Laboremus seems to have been the motto of Sainte-Beuve, as it was that of Septimus Severus. He died in harness, and up to the evening before his last day he still wrote, overcoming the sufferings of the body with the energy of the mind. To-day, at this very moment, they are laying him in the bosom of Mother Earth. He refused the Sacraments of the Church; he never belonged to any confession; he was one of the 'great diocese,' that of independent seekers of truth, and he allowed himself no final moment of hypocrisy. $\mathrm{He}$ would have nothing to do with any one, except with God onlyor, rather, the mysterious Isis beyond the veil." **

\section{Taine.}

Taine is the best representative of French thought under the Second Empire. Victor Hugo, Michelet, were incomparably superior to him in poetic power: but they were survivors of a defeated generation; their position, although honoured, was isolated, eccentric. Auguste Comte, Renouvier, Vacherot were more original and more consistent thinkers: but they were not in touch with the general public. Sainte-Beuve and Renan ranked with Taine as the intellectual leaders of the age. But Sainte-Beuve laboured for many years under the unpopularity which his early adhesion to the Empire had brought upon him : complex, cautious, even timid, he did not openly assume, until the last few years of his life, the authority and responsibility of a leader. Renan, with his ecclesiastical grace, his elusive irony, his Celtic dreaminess, seemed distant, superior, enigmatic. Taine, rigid, fearless, brilliant, assertive, and forceful, was, from his student years at the Normal School to his death, a master.

Taine's career is remarkable for its unity of spirit, method, and purpose. Yet the events of 1870-71 coloured his imagination and influenced his judgment to such a point that the historian of The Origins of Contemporary France seemed

\footnotetext{
* Amiel's Jowinal, translated by Mrs. Humphry Ward, Macmillan, 1891.
} 
repeatedly in contradiction with the author of Classical Philosophers or English Literature.* We have to deal exclusively with Taine under the Second Empire. Then he was considered as a thoroughgoing exponent of Positivism and even materialism. Scherer, with cold and still uncertain sympathy, Caro, with nnctuous hostility, $\dagger$ Mgr. Dupanloup, with open violence, denounced him as such. He himself, without doing homage to Comte or Littré, accepted the name. "Of all three," he wrote in his private notes after a discussion with Berthelot and Renan-" of all three, I am the most radical Positivist." $\ddagger$

Taine first asserted his position by a masterpiece of destructive criticism, French Philosophers of the Nineteenth Century. Young Positivism challenged official Spiritualism to mortal combat. Witty, disrespectful, cutting, this book created scandal. Taine was accused of seeking revenge for private wrongs by attacking a whole school of philosophy, pouring ridicule, not only on the living head of that school, but on dead masters-Maine de Biran, Royer-Collard, Jouffroy-whom he had not personally known. He was blamed also for introducing the brilliant and effective methods of journalistic polemics into the austere and serene domain of abstract thought. The younger generation sided with Taine, and posterity seems to have ratified their verdict. The eclecticists or spiritnalists whom he so effectually ronted were not entitled to the immunities and privileges of pure philosophy. They had become as a school time-servers, administrators, orators, rather than disinterested thinkers. Taine did not dislodge Spiritualism from its official stronghold: he granted that its domination would last for another quarter of a century, and it outlived that term by a decade. But, in spite of State support, eclectic Spiritualism

* E.g., his defence of the Jacobins against Carlyle (English Literature, v.), the most spirited refutation that has yet been offered of his own great work on the Revolution. The change was so complete that many of his enemies in the Academy in 1861, when they refused his English Literature a welldeserved prize, had become his supporters in 1878 .

† In L'Idée de Dieu et ses Nouveaux Critiques. † Corr., ii., p. 244.

$\$$ First published as a series of articles, later remodelled, softened, and renamed Classical F'rench Philosophers. 


\section{FRENCH PROPHETS OF YESTERDAY}

was no longer a living doctrine. Taine did his country an excellent service by proclaiming the fact abroad. Philistine common sense, vested interests, order, prudence, and rhetoric were idols which he refused to worship.

More courteous, but no less unequivocal, was Taine's condemnation of the Romantic or sentimental spirit in religious philosophy. His article on Reynaud's Earth and Heaven was his first contribution to the Revue des Deux Mondes (1855); he was twenty-seven, and spoke with the finality of a supreme judge. There was no suspicion of selfishness or insincerity abont Jean Reynand: but at the back of his poetical and harmless transmigration theories there lurked the old fallacy of Chateanbriand: "I desire this good, therefore I shall have it. My dream is pleasant, therefore it is true." But the truth of a doctrine, answered Taine, has nothing to do with its beanty, any more than with its usefulness; philosophy is neither an instrument of government nor an invention of poetry : "Let us therefore separate science from poetry and from practical morality. . . Science must not accommodate herself to our tastes, but our tastes to her dogmas; she is a queen, not a servant; and if she be not a queen, then she is the vilest of all servants, because she belies her nature and demeans her dignity. Let her not think of governing the crowd; let her remain in solitude; let her pursue truth alone; dominion will come to her later, or it will never come, it matters not. She is miles above practical and active life; she has reached her goal, and has nothing more to do or to claim, as soon as she has found truth."

This defines nobly the true scientific spirit as found in Darwin, Pasteur, Littré, Claude Bernard, Berthelot. Philosophers, critics, historians had hitherto too often relied on their imagination and their personal judgment. Taine set up a new standard as exacting as that of the chemist and the physiologist. And so far as in him lay he lived up to that standard. In spite of his delicate health he was an incessant worker, and gave a splendid example of industry and conscientiousness. After conquering a certain kind of popularity and well-deserved authority he never relaxed. In his books he marshalled a formidable array of 
minute facts, and back of them one feels the presence of a still more formidable army held in reserve. To all appearances, therefore, Taine made good his claim to a place among positive scientists. He served truth alone, and sought truth in the observation of facts.

But the elimination of all practical or sentimental considerations was only the first point of Taine's scientific creed. The next step was the proclamation of the absolnte mity of science, in other words the assumption of monistic determinism. This doctrine, which had taken a strong hold of Taine's imagination even while he was still in college, was implied in his Essay on Livy, and was expressed with remarkable precision in the short preface which, after securing an academic prize, he added to the work: "Man, says Spinoza, is not in Nature like an empire within an empire, but like a part in a whole; and all the motions of the spiritnal automaton which is our being are as well regulated as those of the material world in which it is included." * Later, in the Introduction to his History of English Literature, he spoke, if not more strongly, at least more crudely: "Whether facts be physical or moral makes no difference : they must have causes ; there are causes for ambition, energy, truthfulness, just the same as for digestion, muscular motion, animal warmth. Vice and virtue are products, like vitriol and sugar, and any complex notion arises from the combination of simpler notions on which it depends." †

So far Taine seemed to be a materialist pure and simple, a lineal descendant of the eighteenth-century plilosophers, a Lamettrie, a d'Holbach with a wider range of culture. His admiration for Condillac, the theorist of that school, whose method he so unreservedly praised in his Classical Philosophers, lent colour to this interpretation; there was much truth in it. After the collapse of Romanticism and eclecticism the eighteenth century did revive, not in Taine alone, but in many of his contemporaries, and these among the greatest. It was the time when Sainte-Benve boasted that " the eighteenth century in all its crudity" was the true foundation of his beliefs; when Proudhon said to Persigny: "Volney, sir, is my master-

* Essay on Livy, Preface, 1856.

† Littérature Anglaisc, Prefacc, xv. 


\section{FRENCH PROPHETS OF YESTERDAY}

Volney, Dupuis, Fréret, Diderot, d'Alembert, Voltaire, the Physiocrats, Condillac, Molière, Bayle, and Rabelais : these are my Fathers, such is my tradition"; * when Michelet wrote: "The great century, I mean the eighteenth. ..." Eighteenth-century science, narrow as it was, had achieved notable triumphs, and there were enduring qualities of clearness, directness, sincerity in eighteenth-century thought. After fifty years of unjust disparagement all this great effort was at last appreciated.

Such was the fundamental element in Taine. We have his own word for it; the man who in his latter years denounced with such bitterness the classical spirit, as revealed in the French culture of the eighteenth century, belonged essentially to the school he fulminated against. "My turn of mind is French and Latin; to classify ideas in a regular and progressive order in the way of naturalists, according to the rules of ideologists, in a word oratorically." $+\mathrm{He}$ was first of all a logician and an orator. It was the flawless concatenation of propositions and cousequences in Spinoza that won his adhesion. He was more interested in ideas, in laws, in causes, than in positive facts or in poetic fancies. His method, which he opposed at the same time to the arbitrary spiritualism of Cousin, to the agnosticism of Littré, and to the empiricism of Stuart Mill, was based on three operations: analysis, abstraction, generalisation; it was the method of geometry and pure logic, the simplest form of Rationalism. The aim of such a method is the discovery of axioms, from which all secondary truths can be inferred deductively. In fact, in the first part of his career geometrical comparisons are very frequent in Taine's writings. He borrowed Hegel's "History is living geometry," and went so far as to say, "A man is an axiom." With his theory of the "ruling faculty" he attenpted to give the definition, the formula, of a man, as mathematicians give the formula of a curve. This was strikingly exemplified in his Liry at the begimning of his career, in his Napoleon at the end. Taine was too learned and too clear-sighted, of course, to maintain that the results of psychology and history have the same unerring 
accuracy as those of mathematics. In a letter to Ernest Havet* he limited and toned down some of his previous affirmations. There are exact and inexact sciences, the first grouped round mathematics, the second round history; both deal with quantities, but in the first case these quantities are measurable, in the second they are not. The necessary and precise relations which exist between historical factors, although not measurable, are entitled to the name of laws, like the similar relations which exist in natural sciences. But the very words inexact sciences imply an aspiration towards the complete, the perfect type of the exact sciences. The discovery of generative formulæ, which he identified with causes and endowed with a sort of metaphysical existence, remained Taine's ultimate goal. The conception of the world which results from such a system is admirably described in the last page of Classical Philosophers. From abstraction to abstraction we rise to the notion of a few supreme laws, and finally of one from which all the others are deduced. Such is the final object of science. "Then the notion of Nature begins to dawn upon us. Through this hierarchy of necessities the world forms a single and indivisible being, of which all beings are members. At the summit of things, on the ultimate height of luminous and inaccessible Ether, the Eternal Axiom is uttered, and the prolonged repercussion of this creative formula engenders by its inexhaustible undulations the immensity of the universe. Any form, any change, any motion, any idea, is one of its acts. It exists in all things, and is limited by nothing. Dratter and thought, planet and man, armies of suns, an insect's palpitation, life and death, grief and joy, there is nothing that does not express it, and nothing that expresses it completely. When its serene and sublime face is unveiled there is no man's mind that does not reel, struck with admiration and horror. At the same moment that mind recovers: it forgets its mortal destiny and its insignificance; it enjoys throngh sympathy this Infinity which it conceives, and partakes of its grandeur." †

Such a conception is absolutely exclusive of a personal God, and of any form of sentimental religion. On this point Taine

* 1864, Corr., ii., p. 299.

† Philosophes Classiques, p. 371. 


\section{FRENCH PROPHETS OF YESTERDAY}

did not vary. In politics he veered in after-life to extreme Conservatism, and thereby won the admiration and sympathy of the Catholics. As a historian he came more and more to realise the admirable work done by the Church in saving from the wreck of the ancient world some fragments at least of human culture; as an artist, as a reader of Chateaubriand and Michelet, he felt the deep poetry of faith and worship: "There is no need for us to give up poetry or to break with the past. We remain on our knees before the sanctuaries where for three [sic] thousand years mankind has prayed: we do not tear a single rose from the wreaths with which it has crowned its divine Madonnas; we do not put ont a single one of the lamps with which it has covered the steps of its altars; we admire with an artist's pleasure the precious shrines in which, amidst wrought candelabra, sums of diamonds and resplendent copes, it has lavished the purest treasures of its genius and of its heart." * But beyond these hallowed forms he sees the "impalpable ideal," the "profound generating powers," the invisible, unchangeable Laws, by which all living forms come to the light of day. His rigid determinism was not affected by his historical or æsthetic sympathies. On the central question of religion, that of a personal God, he remained at the antipodes of Christianity.

Sometimes his hard and dry Rationalism, under the influence of Goethe and of Romanticism, would seem to expand, to soften, to become organic. The universe, instead of a system of inflexible laws derived from "the eternal axiom," would appear to him as a life, as a being: "Wherever there is life, even brutal and maniacal, there is beauty. The more one contemplates nature the more divine it appears, divine in its rocks and in its plants...." This intuition of the living unity of nature, which he admired so much in Goethe, did not perhaps exist spontaneously in him; but he understood it, reproduced it, cultivated it, and in all his works there are pages of enthusiastic, almost religious, description. But, admirable as they are, these passages are "purple patches," bits of naturalistic pantheism tagged on to the drab coat of eighteenth-century Rationalism. Taine starts from the laws of the material world, and applies

* Litt. Ang., iv., p. 353.

t Ibid., iv., p. 354 . 
them to the intellectual and spiritual ; whereas Goethe's point of departure was the concept of life, which, from the spiritnal world, would extend down even to brute matter. Although this organic view of nature has been identified with Germanic thonght, there have been Frenchmen-Rabelais, Diderot, Victor Hugo-who held it spontmeously, and gave it magnificent expression. Taine was not one of them. In his pantheistic passages he impresses us as a virtuoso or as an inspired translator.

Taine's rationalistic and monistic philosophy was much richer in its details and much more grandiose in its ultimate developments than the commonplace and shallow doctrines which generally go by the name of Rationalism. It represents the aristocracy of its kind. But its fundamental identity with them cannot be denied. Taine wrote to Havet in 1878: "The legitimate queen of the world and of the future is not what in 1789 they called reason; it is what in 1878 we call science." But his conception of science was two generations bebind that of Pasteur, for instance; it remained a metaphysical-logical system propped up by immumerable facts, instead of a disinterested collection of facts leading to provable results. Although Taine's erudition blinded most of his contemporaries and himself, he was not a scientist, but a logician. If, following his own method, we attempted to give his formula, we should call him a French rationalist dragged skyward by Hegel, earthward by Stuart Nill, and making the best of the situation.

Magnificent, but cold and comfortless, seemed the transcendental geometry which in "M. Paul's" system took the place of metaphysics and religion. It satisfied certain intellects, but held nothing for the heart. Spinozas and even Vacherots are infrequent visitors in this world, and there is something almost inhuman in their power of mental abstraction. Taine was their worthy pupil: it was said of him, when he was still a very young man, "He will live for thinking," and he verified the prediction. Yet he remained human, all too human, and his scientific determinism was perhaps naught but a mask, or at least a discipline heroically accepted.

Taine was not an Olympian, like Goethe; his mind was sensitive and passionate. His view of the world was not calm, 
orderly, serene, like his philosophy, but violent and sombre. In his chapter on Shakespeare he summed up the psychological conceptions underlying the French and the English dramas. To the reasonable and logical psychology of Descartes, Corneille, Racine (! ?), he opposed Shakespeare's: "Man is a nervous machine, governed by his temperament, subject to hallucinations, swayed by uncontrollable passions, essentially unreasonable, a compound of the beast and the poet; verve is his wit, sensibility his virtue, imagination the spring of his actions and their guide; through the most determined and the most complex circumstances he is driven at random to despair, to blindness, and to death." * This psychology, which he ascribed to Shakespeare and Esquirol, was fundamentally his. After the terrible events of 1870-71 his imagination was further darkened, and his Origins of Contemporary France are a gigantic nightmare. But long before, when he was young and successful in an orderly and prosperous nation, he was already a pessimist. The misanthropy of his Life and Opinions of Thomas Graindorge is as savage as Swift's. Under the brilliant forms of civilisation he saw meanness and brutality everywhere. Man was already for him a "lascivious gorilla." From a single chapter we cull the following notes: "From the age of twenty to thirty man, with great difficulties, strangles his ideal; then he lives, or thinks he lives, at peace; but it is the peace of a mother who has murdered her first child." $f$ "In order to get an idea of man and life one must have gone to the verge of suicide, or to the threshold of madness, at least once." + "To have an alibi [to escape from the horror and tedium of life]. In our climates one has work, literature, society; in addition, among the lowest classes, alcohol, which is the literature of the poor. In the East they have opium and dreams. . . In Europe we have science. It is also a slow and intelligent suicide." $\$$ Graindorge is only a mask; perhaps Taine should not be held accountable for the gruesome humour of that extraordinary meat-packer and Ph.D. But in Taine's
* Litt. Ang., ii., p. 245.
† T. G., p. 307.
† Ibid., p. 30 s.

$\S$ This conception of science as an opiate is strictly parallel with Leconte de Lisle's-and before him Baudelaire's-conception of art. Science for science' sake-art 'for art's sake: apparent disinterestedness, worst form of selfishness. 
most thoughtful, most dispassionate work, Intelligence, we find at the bottom the same spirit, the same theory. "Madness is not a distinct and separate empire: our daily life borders on it, and we all belong to it through some part of ourselves," said Graindorge. "Our mental life consists in a constant struggle against hallucination. Sanity is an unstable state of equilibrium. A perception is a hallucination that happens to be true," echoes, in his natural voice, Taine the psychologist.

Whilst most rationalists are "once-born men," to borrow William James's useful terminology, Taine was a "sick soul." The disease improperly called "le mal du siècle," which began with Rousseau's Saint-Preux and Goethe's Werther, was not cured at the time of the Second Empire, only it was stoically concealed: "Suffer and die without a word." Like their elders, Taine's contemporaries were sad and inclined to rebellion; happiness seemed impossible, truth inaccessible, society ill-constructed, man corrupt, and his destiny vitiated through some monstrous disproportion in the pieces of his structure. Many ways out of this terrible situation had been attempted : reckless enjoyment, commonplace prudence, ambition, a blind return to the old beliefs: all had failed. Now Goethe's solution was tried: "Seek to know thyself and to understand the world." But even this remedy was not immediately applicable. "Our generation, like its predecessors, suffered from the disease of the century, and will never fully recover. We shall perhaps attain truth, but not peace. Our intellect is all we can hope to cure at present: over our sentiments we have no control. But we have the right to entertain for others hopes which we have given up for ourselves, and to prepare for our descendants a happiness which we shall never enjoy. Brought up in a wholesomer atmosphere, perhaps they will have a healthier soul." *

Perhaps: and this hope alone ennobles scientific research, transforms it from idle curiosity into religious service, from an opiate into a remedy. Meanwhile, what will be the philosopher's attitude in the moral world? One doctrine exists, so sad, so strong, so serene that it appeals irresistibly to the * Litt. Ang., iv., p. 388. 


\section{FRENCH PROPHETS OF YESTERDAY}

pessimist and the determinist: that is Stoicism. Marcus Aurelius, too, saw the sad spectacle of a world in ruins-impoverished and corrupt, worse in every respect than ours. And he, as Emperor, felt the whole crushing burden weighing on his shoulders. "Like a pilot without hope he steered his ship, knowing full well that the ship would sink." * One idea enabled him to remain firm at his post: the conception of Nature as a single being, of which we are all members: "Be comforted, ye suffering men: on all sides immensity envelops you, and imparts its peace unto you; nature, whether it exalts or crushes you, makes you partake of its strength or of its repose." "We have learnt much in sixteen centuries," the critic goes on to say; "but we have discovered no ethical doctrine which equals the loftiness and the truth of this one. Our positive science has penetrated more carefully into the details of the laws which govern the world: but except for differences of expression, it leads to the same general view." +

But Taine's Stoicism never was "active and tender," like de Vigny's; it remained hard, cold, and proud. It was a doctrine of haughty resignation, not of love and hope. Born of determinism and despair, it could lend dignity and unity to a scholar's life: as an organic faith for struggling men and women it was powerless. Taine's influence was immense, but hardly in the spiritual domain; what he taught most efficiently was materialism during the first half of his career, conservatism during the second.

From the moral point of view Taine was a saint. Not one of the amiable type, to be sure, for he lacked abandon and cheerfulness; but one worthy of our deepest admiration and respect. His long literary career was devoted to the sole service of truth, without rest and without fear. As a scholar he had a wonderfully broad culture, omnivorous curiosity, and a mique capacity both for significant detail and generalisation. As an artist, his was not the gift of creating life, nor the power of mystic suggestion: he was great as a painter, although one is conscious

* Nowveaur Essais, p. 98.

+ Ibid., 1856. "Marcus Aurelius is the noblest soul that ever lived" (Ibid., p. 95). 
of a certain strain in his best descriptive passages; he was supreme as an analyst, and we know of nothing in the whole range of literature to match his passionate logic, so masterly and so sincere, at the same time so well controlled and so ardent.

Yet there is a growing sentiment that this lover and servant of truth had in him something fundamentally unsound, and that his influence, on the whole, was not good. Heterogeneons elements-French rationalism, German metaphysies, English conservatism and prudence, romantic pessimism were in him, not harmonised, but forcibly brought together. He whose chief quality seemed to be clearness remains a more equivocal thinker than the elusive Sainte-Beuve and Renan. An appearance of unanswerable logie, a display of minute facts, an imperious style, and above all the ardour of evident sineerity, gave outward unity to a complex and contradietory system. His example strengthened that which is more dangerous than ignorance, and even than frivolity-pseudo-science. Clear, honest thinking in the good old French way, modest, cautious, painstaking research of the modern kind, suffered equally from the success of this pessimistic poet, earnestly masquerading as a logician and a scientist. His intellect was a powerful and delicate instrument which, through some original vice, was untrue: perhaps the harsh word of a political opponent was none too harsh: "Taine est un esprit faux." Always stimulating, always unreliable and dangerous, he has been unduly praised as an intellectual and spiritual leader; whilst his fame as an artist is firmly established, and will probably grow brighter when his scientific claims are dismissed and forgotten. 


\section{CHAPTER IV}

ERNEST RENAN

"Au fond de nous est comme une fontaine de fées, une fontaine claire, verte, et profonde, où se réflète l'infini."-Renan, Saint Paul, p. 205.

"THE characteristic feature of the nineteenth century is the substitution of the historical for the dogmatic method in all studies relating to the human mind. . . . History, indeed, is the necessary form of the study of all that which is subject to the laws of changing and successive life; . . . the science of languages is the history of languages ... the science of the human mind is, in the same way, the history of the human mind, and not merely the analysis of the working parts of the individual soul. . . . The great progress of criticism has consisted in substituting the category of becoming for that of being, the conception of the relative for that of the absolute, motion for immobility." *

These words, found in Renan's Preface to his first published work, Averroës et l'Averrö̈sme, are his declaration of principles, his manifesto as a critic, a historian, and a philosopher. We may not fully accept Renan's method; but there is no doubt that, in his own case, it provides the only guiding thread to the " enchanted maze," as it was aptly called, of his religious thought. The only way of analysing Renan's complex ideas is to trace their origin and their development.

\section{Influences, 1823-48.}

Renan was born in the small but ancient episcopal city of Tréguier, in Brittany. On his father's side his ancestry was of pure Breton stock; his mother was half Gascon. He always

* Averroës, Preface, vii. 
considered himself as a Celt, and took pride in his race; * but he did not disown the Southern element in his blood: the Gascon within him, sceptical, light-hearted, Montaigne's true compatriot, would, he confesses, play "monkey tricks" on the dreamy, melancholy, idealistic Breton. It is exceedingly difficult to appreciate such elusive elements as racial characteristics and influences: Taine's method of ascribing everything to "race, surroundings, and times " often is a hindrance rather than a help. But in Renan's case we are on tolerably safe ground. Brittany is not a mere province of France: geology, history, ethnography stamp it as a little world apart, much more different from the rest of the country than Normandy is from Sussex or Lorraine from the Palatinate. From the religious point of riew, especially, the originality of Brittany cannot be doubted, nor the potency of her action. The whole history of religious thought in nineteenth-century France could be summed up in the study of three Bretous: Chateaubriand, the herald of æsthetic Catholicism: Lamennais in his triple capacity as theocrat, liberal, and humanitarian; Renan himself, who combined and rivalled the influences of Voltaire, Chateaubriand, and Auguste Comte.t

Renan was brought up in the Catholic faith. But that faith was strongly coloured by the national spirit and local traditions. The tremendous progress of Ultramontanism in the nineteenth century has almost obliterated all these provincial differences, so strong before the Revolution, and to the remnants of which a few people clung tenaciously even as late as under the Second Empire. + Breton Catholicism had neither the austere nakedness of Jansenism nor the dignified and reasonable moderation of Gallicanism, still frequently found three-quarters of a century ago among the aristocracy of the Bench; it had little in common with the gaudy materialism of Italian superstition. Rigidly orthodox, and deeply spiritual at the core, it was covered with a thick, fantastic growth of legends and practices, many of which, no doubt, were of pagan and Druidic origin. The clergy

* Cf. Souvenirs and The P'oetry of the Celtic Races.

$+\mathrm{Cf}$. also Hello, the great Catholic mystic, so different from the orators and polomists of the Church.

$\ddagger$ Cf. the quostion of the Lyonnese Liturgy. 
had to tolerate, while trying to discourage, these traditions. Renan's mother, her Breton piety quaintly shot through with Gascon rationalism and humour, would tell the boy the miracles of these strange local saints. It is not indifferent to note that the religion of Renan's compatriots was not so much a system of dogmas or a code of ethics as a rich and naïve mythology.

The whole of Renan's education, up to his twenty-third year, was in the charge of priests. Not only did they inspire him with sentiments of affection and respect which nothing conld efface, but they fashioned his sonl in the image of their own. Renan remained a priest all his life. One could not meet him without being struck by his sacerdotal appearance. Sleek and bland, he was better entitled than Sainte-Beuve to the dignity of bishop " in partibus infidelium." * His soul remained a "secularised cathedral" ; you may turn it into a stable or a barn, there still lingers an all-pervading fragrance of incense. Like his early masters, Renan devoted all his life to the service of the ideal; like them, he showed admirable conscientiousness in the accomplishment of his daily task. Like them, too, he preserved in social relations, and under the form of the most exquisite politeness, a certain aloofness which to the uninitiated might seem the evidence of a cold and selfish heart. He relates in his Souvenirs how his grandmother, under the Consulate, called on a priest whose life she had saved at the time of the Revolution. Instead of the cordial gratitude she expected, she received nothing but coldness, and went away in tears. Renan would have been less rude, but as little moved: a priest is not a man. He loved his sister Henriette dearly, but in his Memoir of her he intimates that he often treated her with seeming indifference. His friendship with Berthelot was admirably pure and lofty : but there was no touch of familiarity, no abandon in it. Henriette and Berthelot, who had not reached the sane degree of sublime aloofness, complained repeatedly of his apparent lack of interest in them. His critics-and they are still as bitter as forty years ago-claim that selfishness was the keynote of his life. $\dagger$ To be rightly

* Cf. Sainte-Beuve's reference to his " diocese."

† Cf. Gabriel Séailles : E. Renan, Essai de biographie psychologique, Perrin, 1895. Excellent, but exceedingly severe. Also, recently, Parigot: Renan, ou l'Egö̈sme moral. 
understood, his attitude should be compared with that of the Jansenists; the famous scene at the wicket is a striking instance of inhumanity dictated by religious conscientiousness. He himself justified the priest who almost rebulied Renan's grandmother, his benefactress, by quoting the words of Jesus, whose unwonted harshness has puzzled so many souls: "Woman, what have I to do with thee?"

There is pride in such self-sacrifice : all stoics, whether Pagan or Christian, are conscious of belonging to a moral aristocracy. The feeling that the service of God conferred the truest and highest nobility was early instilled in Renan's mind, and remained unshaken to the last. This poor boy, whose father was a skipper, and whose mother kept a small village shop, remains in French literaturo as the most complete type of the aristocrat. His courtesy was that of a prince; "transcendent disdain" lurked behind his unassuming and kindly exterior.

In one other respect was the Catholic stamp indelibly imprinted on Renan's mind: he, the freest of free-thinkers, retained in all things the Roman idea of authority. Between his youthful dream of 18t8, The Future of Science, and his nightmare of 1871, the last of the Philosoplical Dialogues, there is one common point: to science, the new religion, should by right belong absolute dominion, with the power of inflicting tortures and death. After a few years of passive hostility, he frankly accepted the Empire; when Sedan had made the Bonapartes impossible, he advocated a return to the legitimate monarchy; and whilst, in his latter years, democracy idolised him blindly in spite of all rebuff's like Caliban, he still professed his inclination for an "enlightened tyranny." We shall see that this lingering fondness for authority, after he had undermined the historical foundation of authority, left his noral and religious theories in a singularly delicate position.

Transferred at fifteen and a half from the small college of Treguier to the Parisian school of Saint Nicolas du Chardonnet, under the direction of a brilliant young Abbé, the future Bishop of Orleans, Mgrr. Dupanloup, Renan saw a new world open before him, less pure, but infinitely more varied, than that of his native Brittany. Joseph de Maistre, Lamartine, Michelet, were 


\section{FRENCH PROPHETS OF YESTERDAY}

revealed to his young mind, and filled it with dreams. The mediæval history of Michelet in particular took hold of him, and enraptured him to such a point that he was unable to take any note. The passages on Joan of Arc, with their exquisite tenderness and pathos, their blending of sound historical criticism with loving reverence for the legend, are the true model of Renan's Life of Jesus and the earlier masterpiece, although by far the less important, is perhaps the more perfect of the two.

From Abbé Dupanloup's preparatory school, Renan passed to Issy, a suburban branch of the illustrious Higher Seminary of Saint-Sulpice. Thus, after a glimpse of the modern world, he was again steeped into the past. Saint-Sulpice had remained practically unchanged since the days of Olier. The Sulpicians had retained, in 1842, the same reserved and dignified piety, the same modest industry, the same other-worldliness combined with reasonableness and learning, which, two centuries before, had made their seminary almost the peer of Port-Royal. The atmosphere of Issy was admirably congenial to the seriousminded young scholar; the " beautiful mystic park," as he calls it, with the ancient peace of its formal and melancholy walks, was ever dear to his memory. But it was at Issy that doubt began to assail him. Renan repeated so often that science, and science alone, had ruined his faith, that most critics simply take his word for it. As a matter of fact, his beliefs were greatly shaken long before he undertook his philological and historical studies. His letter's to his sister Henriette prove this point beyond dispute. It was philosophy, not erudition, which caused him to doubt. Renan was a rationalist before, as well as after, he became a scientist; and Rationalism was taught him by the priests themselves. Although M. Olier had mystic experiences, the piety of Saint-Sulpice bore the imprint of the classical age ; it was strongly tinged with Cartesianism. The influence of Malebranche on Renan should not be overlooked. "I am now reading, with extreme enjoyment, the philosophical works of Malebranche, undoubtedly the finest thinker and the most merciless logician that ever existed," he wrote in January, 1848, ard nearly thirty years later, in his Philosophical Dialogues, it was in the words of Malebranche, "Dieu n'agit pas par des 
volontés particulières," that he expressed the essential principle of his theodicy.* Renan was a free-thinker before he became a Hebrew scholar. "There is another kind of intellectual freedom, wiser, respecting all things worthy of respect, despising neither persons nor beliefs, inquiring calmly and straightforwardly, using the reason God has bestowed because it was given for that purpose, never accepting nor rejecting any opinion on merely human anthority. This is a freedom permitted to all men, and why not to a priest?" + Why not? "Malebranche certainly was a bold thinker, and yet he was a priest, nay, more, a member of a religious congregation." $\ddagger$ It should be remembered that in the Catholic Church it is Rationalism-of a certain kind, of course-that is orthodox, and fideism-the doctrine that faith is based on faith alone-a heresy, as Lamennais, Bautain, and of recent years Brunetière had to be told. Renan tells us indeed: "My faith was destroyed by historical criticism, not by scholastic logic or philosophy," and to all appearances his orthodoxy was intact before he took up the study of Semitic languages. But in the next page he confesses that at the bottom he was already no longer a Christian. One of the director's, as the masters were called at Issy, an ascetic, a mystic, a saint, M. Gottofrey, told him "how anti-Christian it was to trust in reason, what an insult to faith was implied in Rationalism, and he added in a passionate tone: 'You are not a Christian!'" And Renan proceeds to say: "M. Gottofrey alone saw clearly in my soul: he was right, absolutely right: I see it now." The delicate equilibrium between faith and reason which constitutes normal Christianity was broken. It was said that, in the Waterloo of his beliefs, philology was Blücher, the last comer who decides the issue, but Rationalism was Wellington, the first, constant, and principal adversary, the legitimate hero of the field.

His years of study at Issy and Saint-Sulpice, externally so happy and so calm, busy with hard but congenial work, were overshadowed by the sense of the impending crisis. It was

* This principle, "Il n'y a pas do surnaturel particulier"-_Thero is no piecemeal supernaturalism "-so flatly contradicted by William Jame, not only lies at the foundation of all the works of Ronan, but is formally expressed in most of them.

t Brother and Sister, 11:.

† Ibid., 98. 


\section{FRENCH PROPHETS OF YESTERDAY}

evident from the first that he would not sacrifice his freedom of thought; and as he advanced in his studies, he realised more and more that the results of independent speculation and research were incompatible with orthodoxy. Three considerations held him back: the instinctive horror of a pions soul at the thought of breaking with the Church and the religion of his youth; his love for his mother, who had set her heart on seeing him a priest; and his evident vocation for the clerical life, his unfitness for any other. "Even if Christianity were but a dream, the priesthood would always be a type of the Divine," he wrote to Henriette as early as September, 1842. Henriette's influence, on the other hand, was wholly on the side of spiritual enfiranchisement.

Malebranche and all the French philosophers together would probably never have resened our religious freethinker from his perplexity. His masters, in their innocence, placed in his hand the instrument which was to dispel all his doubts-philology. He began his Hebrew studies under M. La Hire at Saint-Sulpice, and, in order to have access to the main body of modern scholarship, he was also obliged to learn German. "This initiation," he said, "marked an epoch in my mental being." * The young Celt seemed to discover his true spiritual Fatherland: "I felt as if I had entered some temple when first I gained the power of realising the purity, the nobility, the morality [of German literature], and its religiousness, if I may take that word and use it in its very highest sense. . . Another thing which delights me about these Germans is their happy way of combining poetry, learning, and philosopby. Such a union constitutes the ideal thinker, to my mind." Renan, who, even before Gobineau, was the prophet of the theory of races, remained at least until 1870 a convinced "Germanist" : the Teutonic people were eunobled in his eyes by their idealism and their lack of practical sense. When his beloved Germany of poets, metaphysicians, and scholars was suddenly transformed into a powerful nation, aggressive, materialistic, brutal, Machiavelian in its policy, cynical in its dealings with the weak and the conquered, Renan's faith received a deep blow; much of the bitter humour in his

* To Henriette, September 22, 1845. 
dialogues and dramas, some of the flippant Epicurism in his later speeches and essays, can be explained by the disappointment this transformation cansed him.

The Germans showed him the possibility of a freer exegesis than the one taught at Saint-Sulpice, and he would often envy the position of these Protestants, who could reconcile their religious spirit with the critical method. But he did not entertain the hope of a similar compromise for himself: his Catholic and Cartesian education precluded such a possibility. One cannot be a "philosopher" and a Christian at the same time: "The Catholics alone are consistent. A single error proves that a Church is not infallible; a single weak point proves that a book is not revealed.* The confession of a single error ruins the edifice of absolute truth and brings it down to the level of human authorities, among which every one picks his choice according to his personal inclination."

The struggle was long and bitter. When Renan left the seminary for the last time, on the 6th of October, 1845, it was not pride, levity, or worldly wisdom that had won the day for free-thought, but conscience alone, and at a heavy cost. Renan and his masters parted with mutual feelings of affectionate respect. His subsequent attitude towards the Catholic Church was ever deferential, and even reverent. In this he was guided first of all by his own feelings; but he was no doubt influenced and warned by the example of Lamennais, the fallen priest, whose anti-clerical violence created a sentiment of repulsion, even among his admirers.

For three years Renan filled a subordinate and ill-paid position in the Crouzet Boarding School, where he met Marcelin Berthelot, his junior by four years. Both were idealists of the purest type, consecrated men, who, in early life, had pledged themselves to the service of truth and never drew back. It was through Berthelot that Renan became so much interested in the natural sciences, which, in after-life, he regretted not to have exclusively cultivated, instead of those "poor little conjectural sciences," history and philology.

We have now reached 1848, the initial year of our special

* Souvenirs, Le Séminaire Saint-Sulpice. 
period. But this rapid survey of Renan's early training was indispensable. Henceforth the tree is full-grown and will bear fruit. A Celt, idealistic, unpractical, his rich imagination haunted with mythological lore, but with a strain of Gascon humour and scepticism in him; a Catholic priest by training and vocation, lofty in purpose, disinterested, aristocratic in his tastes, scrupulously kind and polite, but with a tinge of cold aloofness; a rationalist, who never fully shook off the yoke of Descartes and Malebranche, in spite of his professed allegiance to the ideals of experimental science; an enthusiastic disciple of the Germans in religion, metaphysics, poetry, and scholarship: such was the young man who, in 1848, freed from all bonds, began his wonderful career.

\section{Renan's Life and Works from 1848 to 1870.}

"The year 1848," said Renan, "made a deep impression upon me. I had never given the social problems a thought before. These problems, bursting from the ground, as it were, on a frightened world, took hold of my mind, and became an integral part of my philosophy." As soon as his studies allowed him a short respite he wanted to take stock of his beliefs. He had left the Church for science, as a better means of attaining truth and serving the ideal: was there not a more excellent way, a more immediate duty, the direct relief of suffering mankind? Was not science, under cover of its disinterestedness, "an agreeable pastime, a play for idle folk, an ornament, a luxury, the caprice of an amateur," the least vain of all vanities? "Shame upon him who sings whilst Rome is ablaze!" said Lamartine.

The book which resulted from these anxious questionings, The Future of Science, was thus, first of all, a scrutiny into the author's conscience. The answer was unequivocal: "Yes, science is worth while." The inquiry turned into an apology, or rather a confession of faith; and it was also an immense programme which, with naïve and lofty assurance, the young scholar set for the world and for himself.

The work was too compact, too austere, too revolutionary, too trenchant in tone for immediate success; Renan's guides, 
Sylvestre de Sacy and Augustin Thierry, advised him to use the bulky manuscript as a storehouse for lighter articles, and these "thoughts of 1848" were not printed in their entirety until 1890. But they justify the epigraph which Renan gave them: "Hoc nunc os ex ossibus meis et caro de carne mea." All Renan's philosophy is there: his later publications are merely his first essay divided up, reworked, lightened though enriched, softened and ripened. In 1848 and 1849 Renan contributed to a paper, La Liberté de Penser ("Freedom of Thought"), which was the organ of philosophic Radicalism. There is little trace of dilettantism in these articles - "On Clerical Liberalism," "The State of the Public Mind in 1849." We find in them a neglected aspect of Renan's talent, a polemical, dogmatic, aggressive tone as different as possible from what is called Renanism. The most important of these contributions was an essay on "The Critical Historians of Jesus," a retrospect which inplied a promise.

In 1849 Renan was sent on a scientific mission to Italy. This eight months' tour in the classic country of art had a great influence on his young and receptive mind. Hitherto, as theological student or Semitic scholar, he had not come in contact with the world of plastic beanty. Literature, as literature, this great master of style despised. Hence the crudity, the harshness, the one-sidedness of certain at least of his early opinions. As art, "radiant and consoling," was revealed to him, his stiffness unbent, his illusions fell. The sovereign charm of Rome operated on him. He was then converted to the cult of beauty. Too serious-minded to worship beauty alone, like Théophile Gautier, too honest to subordinate truth to beauty, like Chateaubriand, he came to consider æsthetic charm as a sort of secondary revelation, a guide in our quest for truth. In his latter years Renan may have gone to excess in this dirsetion: he seemed to proclaim the equivalence of beanty, goodness, and truth. But in 1849 the influence of art on him was refining as well as broadening. We may perhaps regret that he did not come in contact, first of all, with the grand and pure genius of ancient Greece, instead of the brilliant and often insincere facility of papal Rome. 


\section{FRENCH PROPHETS OF YESTERDAY}

Renan's taste, very different from his thought, was none of the manliest; there are "sweet" and "pretty" passages even in his strongest works which invincibly remind us of Italian churches in the Jesuit style.

Renan's optimism received a crushing blow in December, 1851. For the idealistic democrats, with whom he had identified himself, the Coup d'Etat was the triumph of might over right, and the people, in whose innate goodness they still trusted, remained indifferent or applauded. The aristocratic feeling which the priests had instilled in his mind revived in all its strength. Humanitarianism, of the romantic-socialist type, became worse than an illusion in his eyes; and the last temptation from his contemplative life to one of immediate action disappeared with the advent of a materialistic and repressive regime.

For the next few years Renan kept up a dual intellectual life. As a scholar, an investigator, his fame was firmly established, and won him a seat in the Academy of Inscriptions and Belles-Lettres; at the same time, his contributions to the Journal des Débats and the Revue des Deux Mondes, meant for a refined but extensive circle of "general readers," brought him to the front rank of modern essayists. Meanwhile his silent but resolute hostility to the Fmpire had ceased; and one of the signs of the liberal era inaugurated in 1859-60 was Renan's appointment to an archæological mission in Phœnicia. This mission was a capital event in his life. $\mathrm{He}$ lost his beloved sister Henriette, his wise and firm adviser in religion and in literature. He visited for the first time Judea, and especially Galilee, which, in spite of the havoc wrought by centuries of Moslem misrule, was to him " a fifth gospel, mutilated but still legible." "Through the narratives of Matthew and Mark, instead of an abstract being, who might have been supposed never to have existed, [he] saw, living and moving, a human figure worthy of all admiration."

On his return, Renan's fondest dream was realised : he was made Professor of Hebrew at the Collège de France (January, 1862). This great seminary, with its freedom from pedagogical trammels and its splendid tradition, the most original and the 
best centre of education in the country, had always been his ideal. But the heated passions of the time did not allow him to appear in his professorial chair more than once. His opening lecture, of a general nature, as usual on such an occasion, attracted a mixed public of Catholic and Radical students. The quickly silenced marks of hostility of the former, the noisy acclamations of the rest, frightened a Government averse to all spontaneous manifestations. A sentence, which was meant to be guarded and conciliatory, in which the lecturer referred to Jesus as "an incomparable man," roused a storm, not so much in the room as later in the Press; the course was suspended, and in 1864 arbitrarily suppressed.

But the turmoil excited by Renan's single lecture sank into insignificance when his Life of Jesus appeared in 1863. The publication of this book was an event of national importance, and the bibliography of all the articles, pamplilets, and bollky treatises which, within a single year, appeared in criticisin, refutation, or praise of this epoch-making work fills a whole volume. Strauss's Leben Jesu had certainly created a great stir, not only among theologians, but in the general public; de Vigny's Diary proves that even poets read it and felt its influence, and the fact that it was translated by such writers as Littré in France and George Eliot in England is in itself significant. But German has not the universal and proselytising qualities of French; Germany in 1835 was not so sharply divided as France in 1863 between uncompromising orthodoxy and radical free-thought, engaged in a life-and-death struggle; finally, with all its merits, the book of Stranss lacked what, in spite of all its weaknesses, Renan's possessed so abundantly -life and genius.

The tangible success of the work was immediate and unprecedented. Within five months, Sir Mountstuart Grant Duff reports, sixty-six thousand copies were sold. Mérimée told his Inconnue that Renan had made over four thousand pounds by his "idyll." Nor was that success merely due to curiosity and scandal. The complete edition, although bulky and expensive, still commands a ready sale; the abridgment published in 1864 with the title Jésus is one of the most popular books in the lan- 
guage. The recent and excellent reprints issued by the Scott Library and the Rationalist Press Association in England prove the wonderful hold that, after forty years, the "fifth gospel" retains on many minds.

Certainly friendly "booming" and favourable reviews had little to do with this triumph. The Life of Jesus was, on the whole, coldly received by the liberal critics. Havet's article in the Revue des Deux Mondes alone was unreservedly laudatory. Scherer's, favourable in the main, was cold and guarded, and contained many serious objections. Sainte-Beuve's was typical of that elusive, many-sided mind: it contained three or four opinions and no conclusion. Although the critic's sympathy and admiration were beyond doubt, it seems that the "second friend," the sceptic, out of patience with Renan's ambignities and his ecclesiastical unction, bears the closest resemblance to Sainte-Beuve himself. Mérimée, a man of great intellectual power, but enervated by his long practice of paradox, fastidiousness, and frivolity, considered the book as a sign of the times, but in itself a trifle. Proudhon's verdict was absolutely unfavourable. George Sand felt compelled to accept the historical results arrived at by Renan, but it was not without disappointment and sorrow: she had lost her Christ, a humanitarian, anti-clerical prophet of the pure '48 type. Neither scholars nor sceptics, sentimentalists nor free-believers were fully satisfied.

As for the orthodox Catholics, their rage was beyond measure. Henceforth Renan became the Antichrist in their eyes. Expiatory services were ordered in all Christendom. From the anonymous lady who sent him repeatedly the terse message, "There is a Hell," to Pope Pius IX., who called him "the European blasphemer," the whole Church militant was arrayed against him. Hello, who had devoted his main philosophical work to $M$. Renan, Germany, and Atheism in the Nineteenth Century, abandoned his mystic realm to refute the historian. Father Gratry, kind, liberal, enlightened though he was, almost rivalled Veuillot in the energy of his anathema; the great journalist himself, forgetting that a career of scurrilous abuse was not the most adequate preparation for theological or historical studies, wrote his Life of Jesus as a 
counterblast to Renan's. Montalembert saw fit to denounce the suspended professor as "a protégé of Cæsar's." Even the dead were pressed into service: some of Lacordaire's lectures were reprinted in 1863 under the title: To the Readers of M. Renan: the Divinity of Our Lord. Jesus Christ. It was darkly hinted that M. de Rothschild had paid him a million for this attack on Christianity.

Most surprising of all was the vigour shown by the smart-set papers, la petite Presse, on behalf of orthodoxy. Spicy periodicals, filled with Parisian scandal, denounced the blameless scholar as " undermining the foundations of public morality." Obscure " chroniclers," as they were then called, whose French was not seldom heretical, accused Renan of not knowing Hebrew. This alliance between Gallic levity and ecclesiastic conservatism, which Renan had scathed in adrance in his article on Beranger's theology, was to him the bitterest trial of all. He thought that all men who served the ideal and led pure lives should stand together against the "practical atheists," the frivolous-minded and the materialists, whatever their professed creed might be. But dogma, not virtue, determined the line of cleavage. Renan's love and respect for his old mother Chureh was put to a severe test.

The significance of the book, for good or evil, was due to its popular character. By "popular" we mean neither vulgar nor superficial: Renan was an aristocrat and a scholar. His erudition has been challenged: no historian, no scientist is infallible. His beautiful style has created a prejudice against him among the Dryasdusts : but we should take Mommsen's word for it : he was a thorough scholar, in spite of his style. His election to the Academy of Inscriptions, his appointment to the Collège de France, the scientific missions entrusted to him-the highest honours that France could bestow-show in what esteem he was held by his peers in the domain of research. On the basis of scientific investigation, Renan wrote a book which was neither theology nor archæology, but human history, a book which could be " understanded of the people." Therein lay the revolution. An abstruse work for the chosen fow would have passed unnoticed and therefore unchallenged: a fifth gospel as acces- 


\section{FRENCH PROPHETS OF YESTERDAY}

sible in language as the other four seemed to herald a new Reformation.

There are four principal conceptions according to which a Life of Jesus could be written. The first, the only one accepted by the orthodox Churches, is a mere Harmony of the Gospels: of this type, Bossuet's remains as good a model as any; Veuillot's, and, with a veneer of philosophy and scholarship, Father Didon's belong to the same class. The second is mainly philosophical: the idea rather than the personality of Christ is its main object. In extreme cases, the personality would be entirely lost sight of, and the Life of Christ would become the study of the formation and development of a myth: such is at least the tendency of Strauss's Leben Jesu. A third type, strictly scientific, would have to be, first of all, critical : the discussion and comparison of all existing documents, and principally of the Gospels, would be practically the whole history. At the time of Renan and in France, this work was done piecemeal by the Strasbourg school of liberal Protestants. The first method takes the whole question for granted; in practice, it leads to great difficulties: flagrant contradictions cannot be reconciled without straining common sense and good faith to the breaking point. The second is seductive, but dangerously arbitrary. The third is purely destructive, and therefore inadequate to the treatment of the capital event in the world's history.

Renan adopted a fourth method, which he borrowed from Michelet, the "integral resurrection of the past." When all authorities have been collected, compared, criticised, a few facts stand out as certain, and the impression of a general trend remains; this, of course, is never indisputable, but it often is highly probable. With these few facts, with this general impression, with sympathy, insight, and a feeling for the laws of life, the historian composes a plausible and artistic narrative. In other words, he offers us a hypothesis which must take all known facts into account, and at the same time conform to our notions of possibility.

The objections to such a method are obvious. The qualities of insight, imagination, sympathy are not to be despised in a historian; when they are kept under control, when facts are 
numerous and well-established, these qualities constitute properly genius, and transmute erudition into real history. They are evident in the best and soundest works of Michelet and Carlyle, and are not lacking in the greatest German scholars, Niebuhr, Ranke, Burckhardt, Mommsen. There is not a page of real history, as distinguished from the mechanical compilation of documents, that is not a plausible and artistic hypothesis. But, when facts are few and uncertain, when there is no universal consensus as to their significance, the personality of the author becomes the main element in the book, and the theory defines the historical romance rather than history.

And what is that "standard of possibility" to which the narrative is made to conform? We shall discuss later, with the rest of Renan's philosophy, his assumption that miracles are impossible; in this particular case we have at least two standards of crecibility, that of the orthodox and that of the sceptic. Even among sceptics there are differences: some, like Mérimée and Sainte-Beuve's second friend, refused to admit as possible the moral miracle of Jesus's perfection implied in Renan's history. Renan smiled at Quatremère and Buloz, because the one, although an orthodox Christian, rejected the miracles " difficult to perform," and the other refused an article on Buddhism, for the reason that "there could not be such silly people as your Buddhists." Yet both were guided by their own sense of possibility. Renan's criterion is either individual fancy, or so-called common sense : and neither has any authority in the matter.

Even if we accepted Renan's theory, his book, as a work of art, would not fully satisfy us. Too bold in his rejection of miracles, or too timid in his criticism of the Gospels, he did not take a decided stand, which would have given unity to the character of his hero. In spite of all his "gentle solicitations," the texts which he had accepted as anthentic and historical agreed in their report of at least some miracles, which he would not aduit. This led him to Euhemerist or rationalist explanations, such as those he had derided in Paulus; and, worse still, he had to fall back, in the case of Lazarus at least, on the 


\section{FRENCH PROPHETS OF YESTERDAY}

Voltairian hypothesis of frand.* This assumption is absolutely in contradiction with his own loving and reverent conception of Jesus. Furthermore, his "young Galilean peasant," without being in any way vulgar, must have been ignorant and narrowminded: all his greatness was spiritual and moral, not intellectual. Yet Renan ascribes to him his own attitude of half-contemptuous superiority, his transcendental scepticism which smiles at all things, not excluding itself, his many-sided and subtle turn of mind which, whilst enabling him to understand all things, would not permit him to judge or affirm anything. As we cannot even think except in terms of our own experience-actual or virtual-all biographers are liable to draw their heroes after their own likeness. But in this case there is absolute incompatibility between the two types of mind, between the firm, earnest, direct Teacher who spoke "as one having anthority," and the cautious, fastidious, over-cultured critic in whose eyes dogmatism was the one unpardonable sin. Every attempt at Renanising Jesus seems a sacrilege to the believer, an inpossibility to the historian, and an error of taste to the artist. +

Even more striking is the contradiction between the beginning and the end of Jesus's career in Renan's book. A historical character is supposed to develop according to the laws of life. Jesus was no exception, and the most orthodox apologists at present speak freely of His growth, an evolutionary view for which there is Gospel authority. $\ddagger$ But Renan, although such a great master of fine shading, shows us a glaring contrast instead of a gradual change. He describes, with a charm not wholly free from sentimentality, $\S$ the "joyous idyll " of Galilee, a happy band of children by the shore of enchanted lakes. Then, with the scantiest transition, we are shown a totally different Jesus, harsh, fanatical, revolutionary, a "sombre

* He abandoned this hypothesis in the thirteenth edition, and accepted Strauss's symbolical interpretation of the miracle.

+ Cf. also Antichrist, p. 102. Friedrich Paulsen has treated of the "irony of Jesus," but that does not include scepticism and self-criticism.

+ Luze ii. 40.

$\S$ E.g., the inordinate use of the words "sweet," "charming," "delicious." 
giant." In this, and by his own tests of harmony and possibility, Renan has manifestly failed.

The Life of Jesus is therefore far from being a perfect book: it is not even Renan's masterpiece. As a work of art, the Antichrist has more power, more variety, more dramatic interest; whilst in point of poetical charm, refined humour, and kindly philosophy, the Sourenirs stand supreme. Like Zola's Downfall, for instance, the book owed its success to its subject, rather than to the perfection of its treatment. Yet, faulty as it is, it remains, not only one of the epoch-making works in French literature, but one of the greatest. There is a blessing for him who dares to wrestle with the angel of the Lord. Renan's portrait of Christ is full of contradictions: yet to thousands of readers it seemed less impossible than the conception of the orthodox. The Empress Engénie, liberal for once, is reported to have said: "It will do no harm to believers: it will do good to unbelievers." A cause of scandal for many, the Life of Jesus was for many more a source of edification. An intense love for truth and goodness, for the ideal as embodied in Christ Jesus, pervades these imperfect and incomplete pages. No man has ever been the worse for reading Renan's Life of Jesus.

The attitude of the author, so bitterly assailed on every side, was full of serene dignity. He replied to none, and pursued his work with the same calm as if his volume had passed unnoticed. He could never be drawn to speak an unkind word against the Church which was so unscrupulonsly reviling him.

In August, 1863, whilst the controversy was at its height, Renan, who was seeking rest at Dinard, on the coast of Brittany, wrote a summary of his philosophy, in the form of a letter to his friend Berthelot. This essential document was published in the Revue des Deux Mondes under the title "The Sciences of Nature and the Historical Sciences," and is now reprinted with Berthelot's reply in the Philosophical Fragments. George Sand, whose admiration for the Life of Jesus was somerhat qualified, was enthusiastic about the shorter work. No trace of the storm raging round him can be found in these serene pages.

In 1866 Renan gare the second volume of his Origins of 


\section{FRENCH PROPHETS OF YESTERDAY}

Christianity-The Apostles. This work, valuable in itself, was bound to seem colourless and tame in comparison with the first. In 1869 appeared Saint Paul, full of admirable passages, and yet the most unsatisfactory volume of the whole series. Renan was absolutely out of sympathy with his subject. The second founder of Christianity is rightly considered as the great doctor of Protestantism, and Renan was a Catholic to the core. The last pages of the work are an arraignment of St. Paul as violent as anything Renan ever wrote.*

In the dedication of Saint Paul to Cornélie Scheffer (his wife), Renan said: "Some enormous errors are dragging our country to the abyss: those to whom they are pointed out reply with a smile." The quiet scholar, who had so consistently kept aloof from active politics, did not remain indifferent or idle when he thought his collaboration was needed. In 1868 he published his Questions of the Times. The whole book may be recommended to those who know Renan only as a dilettante. The tone of every article is direct, earnest, and in the case of the early essays therein reprinted, almost aggressive. Béranger's Theology, in particular, is noteworthy as a scathing indictment of Philistinism and levity combined. The Preface contains a fine tribute to the personal policy of the Emperor, so much superior to the one which, under the joint pressure of his Government and of the Opposition, unfortunately prevailed. Renan went farther, and offered himself as a candidate for the Legislative Body. Opposed both by the Imperialists and the Republicans, he was honourably defeated. He was exactly the reverse of a politician: history has vindicated so many of his views that he may be credited with some at least of the qualities of a statesman.

He was on a tour in Norway with Prince Napoleon, when the long foreseen catastrophe occurred. France had declared war on Prussia. With the fall of the Empire, the second period of Renan's life closed. After 1870, Renan, although not essentially altered, appeared in a different light. His later

* Cf. the amusing passage in The Antichrist, p. 200, in which he expresses the pious wish that St. Paul, before his death, may have found the error of his ways. 
writings not seldom seemed to contradict his first. The trend of his elusive thought had been a problem: it became a puzzle. We shall now attempt, from the production of these twenty-two years (1848-70), to trace the outlines of his religions philosophy.

\section{Renan's Religious Philosophy-1818-70.}

The service of the ideal was the foundation of Renan's life. From the first and to the last, he affirmed his faith in "the Divine." In 1845 he wrote to Henriette: "Absolute truth and goodness do exist. We must believe the first and practise the second. The thought of any different world would be a nightmare " (September 22, 1845). His Future of Science (1848-49) opens with the quotation: "But one thing is needful," and this, we are told in the first pages, is "to live the life of the spirit . . . all the rest is vanity." "God is," he affirms again in his article on Feuerbach; "all the rest only seems to be." * And, in the Dedication of his Saint Paul: "Descartes was right not to believe in the reality of the world until he had proved to himself the existence of God; Kant was right in doubting everything until he had discovered duty." Seriousness was in his eyes the prime and necessary virtue of a scholar, a philosopher, a man. He wanted to side with the Churches against their common enemy: frivolity, vulgarity, Mammonworship.t Levity, even under a mask of orthodoxy, seemed to him the worst kind of atheism; earnestness, even in the form of passionate negation, he considered as a tribute to the ideal. The shallow Voltairian "theology" of Béranger, the God of good fellows, the cheap religiosity of grisettes, topers, and Philistines, made him indignant as downright blasphemy. Not the slightest suspicion of insincerity attaches to these declarations. They were not called for in virtue of Renan's official position or party allegiance, for no man was more independent of such ties than he. They were neither brilliant paradoxes nor popular platitudes: the tone of the age was either flippant and cynical, or bitterly pessimistic, or cold and stoic. To affirm such plain spiritual truths, with such quiet

- Etudes d'Histoire Relrgieuse, 418.

t The Apostles, Introduction, Ixiii. 


\section{FRENCH PROPHETS OF YESTERDAY}

force and without a smile, for a man of fastidious taste who despised Beotians and hated charlatans, required no small degree of conviction and courage. Finally, he acted the law he lived by, without fear. His practical life was obviously shaped by his beliefs. No doubt as to his absolute devotion to the ideal is permissible.

We must insist on this all-important question, because it has been obscured by Renan himself. Renan was affected later with what he had called "the pedantry of levity," that peculiarly French disease also defined as "the hypocrisy of cynicism." He seemed to preach the "old bachelor's philosophy" of Ecclesiastes,-Eat, drink, and be merry, for all is vanity, dropping the saving clause : except to fear God and keep His commandments. He would openly wonder whether the frivolous-minded were not right after all. He wonid proclaim beauty-not the conscious, spiritualised beauty of art, but the material perfection of a human body-as true a revelation of the ideal as goodness or wisdom. He rebuked the efforts of temperance societies, which, he said, would rob the people of their little portion of happiness and dreams. He went so far as to apologise to that vulgar idol, the god of Béranger and his Lisette, "a good little god," he said, "kindly and easygoing." There is something exquisitely painful in the spectacle of this white-haired priest, once the not unworthy biographer of Jesus, stooping to the level of vulgar Epicureans.

Although this development took place after the date we have set as the limit of this study, we cannot wholly ignore it. Unless it can be proved that a new Renan was born after 1870, entirely different from the old, our trust in his earlier profession of idealism must be greatly shaken, or at least has to be qualified. In fact, the events of 1870-71 did affect him deeply, and he was, like Taine, thrown off his balance by the accumulated disasters of the "terrible year." Defeat, invasion, dismemberment; a political revolution, an anarchistic uprising, both under the eyes of the enemies; the very notion of national existence obscured; Might proclaimed Right by Renan's masters in idealism: these repeated blows are sufficient to explain a decided change in his turn of mind. The pessimism of his 
Dialogues and first Dramas was to a certain extent a disease, the result of a nervous and moral shock; the good-humoured cynicism, the sceptical flippancy of his later writings * were steps towards recovery, a gradual return to optimism, but still slow, weary, half-despairing, in spite of all smiles. The publication of the Future of Science at the end of his career showed that Renan's mind, unlike Taine's, had righted itself, and that the cure was complete. $t$

But the influence of contemporary events, great as it was, should not be accepted as a full explanation of Renan's spiritual duality. The germ of what wo persist in calling the disease of Renanism existed even in the young seminarist of SaintSulpice. There already was a Gascon within him, as he put it, struggling against the pensive Breton : only for many years the Gaseon was effectually curbed. Did the resistance of the Celt weaken? Or should we not rather believe that, secure in his victory, the Celt would with smiling indulgence allow the Gascon occasionally to play a fer harmless " monkey tricks"? $\ddagger$

The Gascon, as, with due apologies to a great province, we shall now call Renan's Mr. Hyde, may have loomed large in the eyes of journalists and society people: but perhaps the adepts of Renanism in the wrong sense are too apt to forget that their master remained to his dying day a most diligent and most careful scholar ; of all his works he prized his Corpus of Semitic Inscriptions highest, even before his histories of Christianity and of the Jewish people. A few by-products of a fertile pen, dashed off in the intervals between serious labour, should not outweigh twenty volumes of patient research and a whole lifetime devoted to the service of scientific truth.

That the dilettante, the $x$ sthete, the sentimentalist, represented only Renan's lesser and lower self is our firm conviction, after an unbiased perusal of his complete works. We are inclined to go farther and to venture the hypothesis that the

* The last dramas, parts of the Souvenirs, several of the addresses.

t The change is very striking in The Antichrist, the first volume of the Origins published after the war and the Communo. Cf. pp. 102, 141, 200.

f "Un Gascon, sans quo jo lo susse, jouait on moi des tours, incroyables a u Breton et lui faisait des minos de singe" (Souvenirs, Saint Nicholas du Chardonnet). 
"Gascon" had no real existence at all; that he was merely a child of Renan's indulgence and fancy, an imaginary being, not a part of his real self.

Whilst Renan was a stanch believer in absolute goodness and truth, he was thoroughly sceptical as to the erer'changing symbols which are proposed for the ideal. "Everything here below is but a symbol and a dream," he said in Saint Paul.* "Every religious form is imperfect, and yet religion cannot exist without form. The wise man is he who sees at the same time that everything is an image, a prejudice, a symbol, and that images, prejudices, and symbols are necessary, useful, and true." $\dagger$ Dogmatic affirmation, dogmatic negation, are equally one-sided. Renan is the reverse of the Evil Spirit that ever denies: he ever affirms, but ever conditionally. That which is unconditioned is, in its purity, beyond our power of speech; yet it is the only reality, the one thing needful. The forms of our religions and philosophies pass and change like clouds: the essence remains the same. "Happy those who share, even for a single day, in the beatific illusion of a concrete faith! But happier still would be he who, freed from all illusion, could reproduce in himself the Vision celestial, and without millenarian dreams, without chimerical paradise, without signs in the heavens, could out of the rectitude of his will and the poetry of his soul create anew within his heart, the true Kingdom of God!" +

Such was the basis of Renan's attitude. Intellectually it had little in common with Montaigne's or Mérimée's. In the eyes of dogmatists it seemed dangerously akin to Pyrrhonism, nihilism, and laxity. The shallow-minded would ape its negative side, and think they were "Renanising" when they suggested with a superior smile that all was vanity. Both were blind to the fact that universal scepticism such as Renan's was compatible with a living faith, although not with a formal creed; and that such a faith sustained him through fifty years of moral struggles and patient labour.

* Dédicace.

† "Religious Future of Modern Societies," Questions Contemporaines, 415.

† Vie de fésus, 201. 
The intellectual attitude of Renan is well defined enough; his moral attitude was more puzzling. His indulgence towards the end of his life was certainly excessive and misplaced. "To understand everything is to forgive everything." Again, we must remember that he ever kept the same high standard of duty for himself. Thoroughly French in this respect, he hated self-righteousness above all things; his extreme delicacy of feelings, his scrupulous politeness, his fastidious refinement, made it umpleasant for him openly to praise the qualities for which he was noted. Becanse he was a living example of earnestness, industry, and purity, he spoke almost deprecatingly of these virtnes. He would not set himself up as an example and humiliate the weaker brethren with his perfection. There is much self-conscionsness, affectation, and vanity in such it state of mind. It implies excessive introspection, over-culture, subtlety. Renan was not a saint of the rugged, heroic, singleminded type. His scruples may be a sign of weakness; but, dangerous as they are, and even slightly ridiculous, they are not dishonourable.

Besides, Renan's indulgence was not only due to politeness and self-depreciation. It was also the result of genuine kindness and the privilege of a noble soul. Amiel, Allier, and all Protestant erities in general, reproach him for lacking "the consciousness and conviction of sin." This may be due to the purity rather than to the alleged shallowness of his nature. Jesus alone had a right to forgive the adulteress, because, alone without sin, $\mathrm{He}$ could have condemned her. On an immeasurably lower pline Renan had the same right to exereise universal charity. Victor Hugo, Sainte-Benve, for instance, were not qualified for passing judgment on others, or for preaching indulgence; Renan was pure and strong enough to judge and to pardon.

Renan, in a word, had two standards of conduct, like all men. But, unlike most men, he liept the sterner for his own use. $\mathrm{He}$ had an esoteric and an exoteric doctrine. This duality was due to his priestly education and to his early initiation to difficult sciences, the privilege of a few. No ideal could be higher or more austere than the one he sets before the modern priest- 
hood, the servants of truth. But, for ages to come, the very notion of such an ideal will remain inaccessible to the crowd. You cannot impose scientific Stoicism with the infinite patience and self-renunciation it requires on ill-fitted, ill-prepared souls. The ranks of the new clergy should be freely open to all who wish to enter; a time may come when this aristocracy of thought shall embrace all mankind. Meanwhile, the scientist should not go out of his way and proselytise. He would thereby ruin useful illusions which ensure a certain degree of order and comfort in this world. If you destroy those superstitions which, false in their narrower interpretation, yet are symbols of truth adequate to the popular mind, the victory of truth will not be hastened by a single day. Great spiritual ambitions, and even ardent beliefs, in men too weak or too ill-balanced to understand them philosophically, lead, not to progress, but to revolutions. Since Prospero cannot yet control the government of the world as he should and shall, Caliban ought to be made as contented as possible, in his own way, so that he will not brutally destroy the laboratory where the future is being made. Thus we must have a "religion," in the lowest sense, for the people, and, in default of a religion, an easygoing Epicurean philosophy, to soothe the brute and keep him quiet.

But whether it be the result of modesty, kindness, or disdain, there is no doubt that Renan's laxity was external, as it were, an attitude towards others, not towards himself and his ideal. He offers us our choice: "Renounce or enjoy; you cannot do both. But, if you choose the life of the spirit, be humble, and do not despise your brethren. It is well that you should keep a doubt in your mind whether they have not taken the better part. Else you would lose touch with humanity, becoming too wise in your own eyes."

Thus the idealist follows right because it is right, without fear and without illusion. Not only does he not expect any earthly or heavenly reward, but he will even renounce the purest, most disinterested recompense-moral credit for his virtue. No man is absolutely unselfish, unless he is willing to admit that perhaps all his striving is vanity. All fanatics, and martyrs pre-eminently, have an easy task: they are betting on a certainty. The true 
saint is the sceptic, who throws away the good of this world without expecting anything in return.*

But Renan, who showed such exquisite modesty so far as his moral qualities were concerned, did not evince the same abnegation when it came to intellectual attainments. Ho was quite willing to admit that virtue was, humanly speaking, a delusion, and that, in choosing to do good, he might be a dnpe. But he wanted us to know that, although cheated, he was not deceived. He acquiesced in Nature's deep-laid scheme for turning man's selfishness to purposes of her own, contrary to the interests of the individual. He smiled approvil, thereby reconciling his natural instinct to do good with his perverse desire of being clever.

Idealism, refined almost to the vallishing-point, and associated with radical scepticism, is at one of tho poles of Renan's thought. At the other is Positivism. Nothing can be affirmed of the Absolute, except that it is, and the rest seems to be ; but, in the realm of relativity, a certain kind of certitude is possible, and is attained throngh science. Positive, experimental science is our only safe guide here below. It shonld rule our world : at any rate, its method should be the discipline of our thought. Now, the general basis of all science is the law of cause and effect, which leaves absolutely no room for any supernatural intervention. Should this law be disproved, no other would stand, and the whole fabric of our lnowledge, the result of age-long efforts, would topple down. Science posits the exclusion of "piecemeal supernaturalism" within the limits of our experience.

Renan does not deny the supernatural itself, like the materialists of the coarser type: the supernatural envelops us on every side. He even admits the possibility of our universe being a luge experiment, which may liave begun, and may finish, at the will or whim of some transeendent investigator. But, while the experiment is going on undisturbed, it is submitted only to its own laws. What came before, what will come after, is beyoud our scope, and is non-existent for us. Furthermore, he accepts the idea that tho universe may some day become fully conscious, and thus free from existing trammels or laws: the age of miracles is perhaps ahead of us instead of behind us. But, 
humanly and scientifically speaking, we must reject the possibility of any special supernatural intervention in the aftairs of this world.

The importance of such a rejection will readily be seen. Not only does it strike at the root of all great revealed religions, Christianity not excepted, but it is incompatible with the belief in Providence, cherished by many theists, and with the practice of petitional prayer. On this point Renan is almost as trenchant as Taine and Berthelot. Yet prayer came naturally to him, in spite of his Positivism. It was not merely the survival of a Christian habit, it was the inborn tendency of his soul. One could make a beautiful collection of prayers from the works of a philosopher who professes not to believe in their efficacy. The last page of the Future of Science, for instance, a stirring, indignant appeal in The Theology of Béranger, the truly beautiful words on the death of Jesus, * and, best of all perhaps, the closing lines of the "Essay on Metaphysics and its Future," + have the truest spiritual ring. $\ddagger$ But Renan's theory, contrary to his own practice, implied a theology and a form of worship radically different from those hitherto accepted by our race.

Now, was this conception, with Renan, the fruit of metaphysical cogitations or of scientific research? He maintained that repeatedly science alone had led him to such a conclusion. "This [the rejection of miracles] is not the consequence of a metaphysical system," he wrote in The Apostles $\S$; "it is based simply on observation. No such thing [as a miracle] has ever been established. All the pretended miraculous events which we are able to scrutinise closely are found to be naught but delusion or imposture." Yet Renan tells us that "If a single miracle were proved, we could not reject in bulk all those of ancient history." How, then, could a miracle be proved? Only if it took place before qualified, critical witnesses, the modern St. Thomases of the Academy of Sciences. But, even if it did thus take place, these men would simply study it as a

* Vie de Jésus.

† Fragments Philosophiques, 332.

$\ddagger$ The prayer on the Acropolis, perhaps the most perfect passage of poctical prose in the French language, is, of course, pure literature. Yet it shows Renan's persistent fondness for the form and spirit of prayer.

§ Introduction, xliii. 
curious, unexplained fact, in apparent contradiction with the known laws of Nature: no scientific evidence could ever bring them to admit the possibility of a suspension at will of these laws. Besides, no miracle cim be expected under such circumstances. It is a fact recognised in tho Gospels that faith is an essential condition for the performance of "great works": Jesus Himself lost some of His power in the sceptical atmosphere of His own city (Matt. xiii. 58). The enthusiasm that moves mountains is without action on a scientific balance, sensitive to a milligramme. A miracle in a laboratory is therefore an impossibility: but so would be the writing of a great poem, the rise of a great passion-wonders which refuse to come to life under the microscope of scientists, and yet are known to exist. The appeal to the Academy caunot be taken seriously.

We are therefore thrown back on the testimony of witnesses in the past, and Renan's reasoning comes to this: We must reject all documentary evidence in support of miracles as unhistorical, "this is an absolute law of criticism"; why? because there is no historical evidence in support of miracles. Plainly, this is arguing in a circle, and the metaphysical origin of Renan's Positivism becomes apparent. He was, as we have shown from his correspondence with his sister, a disciple of the French rationalists, Descartes, Malebranche, and a contemporary of Comte, Littré, Stuart Mill, Spencer.*

It is hardly necessary to remurk that in thus denying a priori the possibility of recorded events, Renan weakened his position as a scientist and a historian, and laid himself open to the accusation of being merely an enlightened Voltaire with a touch of Chateaubriand in him. Had he placed himself on the more modest and safer ground of experimental science and criticism, his conclusions need not have been very different: for, if we have no right to reject miracles as impossible, it is our duty to crossexamine as severely as we can the alleged witnesses in their sup-

- For the influence of Malebranche, ef. Brother and Sister and Philosophical Dialogues. Littré is tho only one of theso men whom ho ropeatedly quoted as an authority; he denied the originality of Auguste Comte, but in so doing eudorsed nosi strongly his main contention. 


\section{FRENCH PROPHETS OF YESTERDAY}

port: a duty practised even by the Catholic Church before a new saint is added to her Calendar. It may well be doubted whether the evidence of the New Testament writers would at present be accepted by any court not biased in their farour. A great change has certainly come over Christianity in this respect: miracles are now a hindrance rather than a help. Instead of serving as arguments in favour of the faith, they weaken it. The spiritual grandeur of Jesus remains the evidence of His divinity, in spite of the miracles. This very grandeur, to which Renan paid full tribute, is in itself a miracle, incomparably more mysterious and more potent for good than the turning of water into wine.

Renan's idealistic scepticism and his scientific Positivism seem to leave no place between them for historical religions and metaphysical systems. But if there is no certainty beyond the domain of facts, and if all attempts at expressing the unutterable are futile, it does not follow that symbols and dreams are not legitimate. Vague, changing, delusive as they are, they remain our only way of directing our thoughts upwards and of imagining our relation with the ultimate reality. These great epics of human destiny keep the ideal alive. Suppress all illusion, and men will either shudder before the mystery of their fate or lose all concern in it. Poems they are, in the truest sense; creations of human genius, of enthusiasm and virtue; and as such they offer, beside their incomparable spiritual usefulness, a wonderful field for the sympathetic curiosity of the critic and the historian. Like Quinet and Michelet, like Sainte-Beuve, Leconte de Lisle, and even that pagan Flaubert, * Renan found in the study of religions the keenest æsthetic and scientific pleasure.

As for metaphysics, he considered it as an attenuated form of religion, without the glow of enthusiasm and the picturesque, living element: religion spoilt rather than strengthened by an attempt at clearness and consistency. But, too sceptical-or too poor + - to create a religion of his own, he had to be content with

* Temptation of St. Anthony.

$+\mathrm{He}$ suggested that with a few millions one could start a religion in the East ("The Experimental Method in Religion," Nouvelles Etudes d'Eistoire Religieuse). 
metaphysical dreams, never forgetting, however, that they were dreams and not doctrines.

Yet these dreams had one unifying principle-that of devclopment. Life means change; nothing is, everything grows. This notion of becoming as opposed to being was applied by Renan not only to history, literature, and psychology, but to the spiritual world. God, he said, is the sum of our supernatural needs, "the category of the ideal" (that is to say, the necessary form under which we conceive the ideal), as space and time are the categories of bodies (i.e., the forms under which we conceive bodies).* The one thing we know with any clearness about the ideal is our ideal, which, from race to race, from age to age, and, in the individual, from year to year, keeps changing, growing, and, let us hope, improving. The highest conception of the ideal is therefore the nearest approach to God, the clearest consciousness of Him. God, then, has a double existence: one absolute, infinite: of this we can know and say nothing, as it transcends our thought and speech; the other is the manifestation of the Divine in this world, the immanent God within us. In this sense, our consciousness of God may be termed God's consciousness of Himself, His self-realisation through chosen souls, his more and more complete incarnation. "God is immanent in the whole of the Universe, and in each of the beings that compose it. Only He does not know Himself equally in all; He knows Himself better in the plant than in the rock, in the animal than in the plant, in man than in the animal, in the intelligent man than in the dullard, in the man of genius than in the intelligent man, in Socrates than in the man of genius, in Buddha than in Socrates, in Christ than in Buddha. Such is the fundamental thesis of our theology. If such was the meaning of Hegel, let us be Hegelians." +

Every progress of the ideal means therefore a progress of God. God, as a growing consciousness through the world, is

* Etudes d'Histoire Religieuse, M. Feuerbach, p. 419. Note again the influence of Malebranche. Cf. Vigny's "Son Verbe est lo séjour de nos intelligences-Comme ici-bas l'espace est lo lieu de nos corps."

† "Sciences of Nature and Historical Sciences," in Fialogucs ct Fragments Philosophiques, p. 187. 


\section{FRENCH PROPHETS OF YESTERDAY}

" in the making." $\mathrm{He}$ is not yet fully: He shall be more and more. To help His self-realisation is to serve the one purpose of the universe, and to partake of eternal life. When God is perfect, $\mathrm{He}$ will be conscious of all the efforts that have made His completion possible; all the obscure workers towards the great end shall then live again in His thought; they shall rise from their æonial sleep, which to them will be as brief as an instant. Personal immortality may thus be the reward of those who have advanced the coming of the Kingdom. Thus religion consists in worshipping in spirit and in truth, without any personal hope or desire, and solely for the self-realisation of the Divine, or, in more orthodox terms, for the glory of Grod. And this was the religion of Christ as Renan takes it, the " absolute and final religion." In His feeling of union with the Father Christ was truly Divine, truly the Incarnation of God.

After a new term of daily intercourse with this great master, we feel more than ever how crude, how incomplete is our sketch of his all-embracing thought; clearer, too, is our belief that his teaching was, on the whole, positive, and, like the example of his life, a power for good.

A genius of the ardent, missionary type, like St. Paul, even with a touch of fanaticism and heroic madness, appeals more strongly, not only to the popular mind, but to every one's heart, than a critic and a philosopher, however intelligent and stainless he may be. We keep our sympathy for high-aspiring men wounded in the battle, like Lamennais or Proudhon, rather than for one who had also a hard fight to go through, but triumphed, and received his dne reward in the form of prosperity, respect, and praise. We like to meet even the greatest on equal terms, as human beings like ourselves: Renan's smile of polite aloofness is an impassable barrier. He keeps us at a distance, as he kept even Berthelot. For these reasons, we cannot entertain for him the same warm feeling as for some weaker and lesser men. Yet this should not make us unjust towards him; we should not seek in criticising him a mean revenge for his superiority. And this seems to be a favourite sport with his modern biographers. 
They call him frivolous: but for fifty years he devoted his strength to minute and patient research, and died in harness, leaving forty scholarly volumes behind him. They call him elusive and shifty: but he never varied in his main course, and, when he presented alternative hypotheses, he did so out of broadmindedness and candour. They call him pliant, effeminate, a moral weakling: but he went boldly through a spiritual ordeal from which most men of the rugged and strenuous type would shrink and seek refuge in dogmatism or compromise. They call him selfish and a Hedonist, whilst he preached and practised absolute renunciation to whatever was not the ideal. They rebuke him for his smiling benevolence, as if cheerfnlness was not the supreme grace of the strong, and indulgence the privilege of the pure.

Democratic France, whom he criticised unsparingly, and, we believe, unjustly, understands him better than the cultured few he tried so hard to please. She instinctively reveres him as one of her spiritual masters.*

* It is instructive to note that the two most famous adepts of Renanism, Jules Lemaitre and Anatole France, showed no lack of conviction and decision when called upon to act: they took opposite sides in the Dreyfus crisis, but with equal energy. This holds true of Barrès and Bourget, whom Professor Irving Babbitt places among the Renanians, although they aro more obviously the followers of Taine (and in a minor degree of Stendhal). 


\section{CONCLUSION}

The study of Renan brings our survey to a fitting close. A Catholic by birth, education, and temperament, a Protestant in his conservative and reverent freedom of thought, a Rationalist after Descartes and Malebranche, a Positivist with Littré, Taine, and Berthelot, a sceptic like Montaigne, a metaphysician of the Hegelian school, a Voltairian in his irony, a disciple of Chateaubriand in his æsthetic emotionalism--he was the living synthesis of his nation and of his time.

If we glance back on these twenty-two years, we cannot help being impressed with their intellectual activity, and with the intensity of their spiritual interests. This view is contrary to a prejudice of long standing. Liberals and Democrats, half a century ago and almost to the present day, were wont to deplore the profound decadence of French literature under the Empire, ${ }^{*}$ and the cynical frivolity of that period has remained a byword. We are beginning to wonder at the short-sightedness of these criticisms, just as, let us hope, our successor's will wonder at our injustice to the greatness of our own age. A time when Victor Hugo, Vigny, Sainte-Beuve were at their best; when Michelet, Quinet, George Sand had fallen little, if at all, below their highest standard; when the new generations could boast such names as Taine, Renan, Scherer, among historians and critics, Flaubert and the Goncourts among novelists, Augier and Dumas among dramatists, Leconte de Lisle among poets; while science was represented by Claude Bernard, Littré, Pasteur, Berthelot-such a time shows no sign of decay, no lack of power and earnestness in the French mind.

* Cf. Scherer, L'Ere Impériale. 
Nor should the catchword "imperial corruption" prevent us from recognising the high spiritual aspirations of that epoch. Without mentioning the activities of priests - and Lacordaire, Dupanloup, Gratry are not to be slighted-a nation cannot be said to be indifferent to religious problems when it takes interest in such works as Guizot's Meditations, Reynand's Earth and Heaven, Proudhon's Justice in the Rerolution and in the Church, Sainte-Beuve's Port-Royal, Scherer's early essays, Renan's whole production, and when the "echo of his century," Victor Hugo, could write such immense theological epics as The End of Satan and God. These works, cited at random, were not isolated : they are but a few peaks in a mighty range. Novels, poems, and plays were full of religious problems and mystic lore. Innumerable were the books and pamphlets on "religion and science," "atheism," " independent ethics," " duty," " natural theology," ecclesiastical controversies, the history and psychology of spiritual movements. The Life of Jesus and the Syllabus were national events. For months the glittering, frivolous Paris of Napoleon III. talked of little else. Hundreds of articles, scores of volumes, were written for and against these two documents. France in the sixties, materialistic as it seemed, discussed religion with an intensity, an earnestness; which contrasts curiously with the good-humoured indifference of the British and American public at the present day.

But-and this was even more striking-all this activity was cheerless. In the fields of commerce and industry there was a certain spaciousness of spirit, a joyous enthusiasm, as of a young giant, very different from the present cantions tone of the business world in France, and comparable only to the buoyancy and energy of the American West. In the spiritnal world there was no listlessness, but a chill gloom prevailed. The Humanitarians had lost the day in 1848; the Catholics were bitterly aggressive in their retrograde policy; the Positivists, although neither despondent nor diffident, were fully aware of existing evils, cautious and slow in their hopes of improvement. It seemed as though, after an indecisive battle, overybody felt disappointed and uncertain of the future. 
The Supernaturalists, who called themselves the Orthodox, held pessimism to be an essential part of their faith. They believed human nature corrupt, as the result of the Fall, and physical nature a delusion and a snare: this world was a vale of tears, this earthly life a time of trial and affliction. Salvation was impossible without celestial assistance; happiness, justice were not to be expected in this life, but in the life to come. The Naturalists thought this earth was fair, and man essentially good: noble aspirations, pleasure in doing right, love for his fellow-mortals, were inborn in him. If only the theological nightmare which caused absolutism, intolerance, oppression could be dispelled; if, freed from the inhibitions of self-diffidence and terror, all the expansive forces of the human soul were released, the Golden Age, the "Kingdom of God among us" would be at hand. It would be unjust to say that Humanitarianism was tried in 1848 and was found wanting. It was not given a fair chance. This, in itself, proves that as a working faith it was at least premature: even if it was not fundamentally wrong, men were not ready to receive it. Such was the conclusion genorally drawn. Belief in human nature was rejected; belief in a supernatural world, where all the ills and injustices of this one would be righted, was greatly shaken and more than half-ruined. The result was despair-the sombre resignation of Taine and Vigny, the blasphemies of Leconte de Lisle and Mme. Ackermann.

Supernaturalists and Humanitarians had more in common than they thought. The Christians believed that man, by ronouncing his nature, by dying to himself, could be made worthy of eternal bliss; the Humanitarians, that if man followed his nature and was more fully, more truly himself, he would be good and happy here and now; both admitted the possibility of sudden regeneration, of conversion, from worldliness in the first case, from artificial civilisation in the second. It was this very notion of miraculous change that the Positivists rejected most emphatically. There is a lack of adjustment between the parts of Nature, and this is the cause of our sufferings. Only a slow process of adaptation can reduce the existing friction-a process partly automatic, in the form of 
nataral selection, partly conscious, in the form of culture. With the progress of science, the material and social conditions of existence will be improved: the Positivists in the broader sense, Sainte-Beuve, Renan, were, like George Eliot, "meliorists." But their meliorism was full of sadness, for they had to give up their golden hope of the immediate coming of the Lord. They, like Scherer and Mme. Ackermann, mourned for the lost Absolute. Even if they had reached, like Vigny and Taine, "that high degree of stoic pride" which gives resignation in default of happiness; even if, like Vigny in his last poems and Renan in his first work, they could foresee in the distant future a stage of civilisation immeasurably happier than ours, they knew that their faith was incommunicable to the masses, and could afford no immediate relief to the ills and woes of humanity. Centuries of patient toil and suffering-an imperceptible progress, offset by increased needs and aspirations - that was all they had to offer. They believed that the old illusions-theological and humanitarian-were dying. They felt that the coming hope was too far off and too cold to have any virtue. Would there be an interregnum, abandoned to materialism and despair? What was to be the religious future of France? $*$

\section{A Return to Christianity: Protestantism and Catholicism.}

The first possibility to be considered was a return to orthodoxy. To accept such a hypothesis required an act of faith : the trend of events seemed to run in the opposite direction. The historian, however, should not limit his view to a quarter of a century. The Church has known dark eclipses and gone through innumerable trials. She has survived persecutions, heresies, and even those subtler agents of disintegrationcriticism and indifference. If she has indeed the words of eternal life, what shall prevail against her? Sixteen centuries after Julian, two centuries after Voltaire, she has lost none of her vitality.

* Cf. Guizot, Méditations, and the reviews of the series by Sainte-Beuve and Scherer; Renan, Metaphysics and its Future, The Future of Science, Natural Sciences and Historical Sciences, The Religious Future of Modern Societies, Philosophical Dialogue. 
"The Church," in France, meant Roman Catholicism. No doubt could be entertained on that point. Protestantism counted for little in national life, and showed no sign of a genuine revival. It would be ridiculous to assert that the country of Calvin and Coligny was congenitally unfit for such a form of religion. The same needs existed in France as in England or Germany: only they were supplied in different ways. Protestantism stands for a historical movement, the Reformation, and for a spiritual attitude, individual freedom. The historical movement was confined to one century: since the close of the religious wars, no nation as a whole has changed its allegiance, and in none have individual conversions been so numerous as to modify in any appreciable manner the balance of power between the two Churches; the ecclesiastical map of Europe has remained substantially the same since 1648. Wherever Protestantism had conquered a strong hold before that date, it endures to the present day, as a faith based on authority and tradition, a conservative orthodoxy, a junior branch of Catholicism. In France, after a splendid start, political circumstances worked against it: its fate was sealed by the abjuration of Henry IV. Had not the Edict of Nantes been revoked, the Protestants would none the less have remained a hopeless minority, if not a negligible factor. At present, the descendants of the Huguenots form a small group, remarkable in every respect, but without any power of expansion. Proud of their ancestry, helping one another in every legitimate way, they do not seek, nor even welcome, converts. They are an hereditary spiritual aristocracy, and, like the last feudal families, an interesting survival. What little missionary work is done in France is due to the efforts of foreigners, or of a few natives under foreign leadership : hence the disheartening results of these attempts. It was hoped that the separation of Church and State would open an era of conquest for French Protestantism: financial and dogmatic difficulties have been, so far, the only fruit of the new regime. Traditionally, Christianity in France is linked to the Roman Church.*

As for the second aspect of Protestantism-spiritual indi-

* Cf. Renan, Saint Paul, p. 287. 
vidualism, religious free-thought-it exists in France, but in a slightly different form, and under another name. The revolt against all external authority has not spared a book which, hallowed, collected, preserved, edited, interpreted by the Church, is a Church in itself. The men who fixed for us the canon of Holy Scriptures had no more rights over our souls than any priest, bishop, or pope. Remoteness in the past does not make their overlordship any more legitimate. Why shonld their Bible be our Bible? Starting from true Protestant principles, carried to their inevitable end, the French refused to bow the knee to a paper Pope. Not merely the interpretation of a Bible but the selection of his Bible, is the privilege of every independent thinker.

Through no fault of its own, French Protestantism missed its opportunity in the sixteenth century. In the twentieth its position is extremely difficult. As the embodiment of the Christian tradition, it cannot compete with Catholicism; as the champion of spiritual freedom, it is left far behind by secular philosophy. It represents neither the past nor the future.

The great weakmess of French Catholicism in the nineteenth century was its constant alliance with all forms of reaction. This proved repeatedly fatal both to "the throne" and to "the altar." Clericalism was the chief accusation against Charles X. and cost him his crown. The Roman Question was for Napoleon III. a cause of endless difficulties at home and abroad. On the other hand, all the odium of unpopular regimes fell heavily upon the Church. In our own days, at the time of the Dreyfus case, the Catholics have shown once more their unfailing instinct for taking the wrong side. In spite of the efforts and warnings of clear-sighted and moderate men, the Church has come to be identified with every obstruction to progress.

America offers us a different spectacle: here Catholicism is held to be, on the whole, liberal, progressive, tolerant, scrupulonsly nentral in polities; a few harmless manifestations, like a platonic vote by a Catholic convention in favour of the temporal power of the Pope, are politely ignored by the general public. The reactionary attitude of the French Catholics is partly due to the misguided loyalty of a few influential monarchists, who 
have "captured" the Church as a political and social organ. isation. If she could free herself from their fetters, and rely on the support of the people, her chances of future progress would be infinitely brighter.

But is this possible? The policy of Rome has been pretty consistent during the past hundred years. Pius IX. bade fair, for a few months, to be a modern and liberal Pope-the new Messiah whom Romantic democracy was expecting. Leo XIII. was an enlightened and accomplished diplomatist. Yet the Syllabus remains the summary of Rome's theory and practice. The theologians who drew up this document under Pius IX. invented nothing; they simply collected and tabulated the decisions of the Holy See. Leo XIII. avoided with consummate skill the difficulties created by his predecessor: but he could not change, and had no wish to change, the invariable principles of the Church. And Pius X. has resumed the policy of reaction with a consistency, a thoroughness, an intensity of conviction which the world cannot fail to respect. "Whoever says that the Roman Pontiff could and should be reconciled with progress and modern civilisation, let lim be anathema."

Every man who attempted such a reconciliation was warned, disowned, condemned. Lamennais and Hyacinthe Loyson were driven from the fold, Lacordaire treated with suspicion, Montalembert and Gratry with positive hostility. The same fate has befallen their successors in our own days: Loisy, the Modernists, Marc Sangnier, have been rebuked, censured, or even excommunicated.

The diplomacy of Rome, perhaps overrated, displays its skill in adapting unchangeable principles to varying national and historical conditions, in veiling or uncovering them as opportunity permits. America, free from theocratic traditions, distant from Rome, and, in spite of rapid changes, still overwhelmingly Protestant, is shown the more acceptable side of Romanism. The Syllabus is glossed over; the American regime of neutrality is cheerfully accepted, praised as an ideal - regardless of the fact that Pins X. condemned, not merely the French law of separation but the very principle which prevails in the United States. England and, above all, continental 
Europe see the Papacy at closer range, and without any veil. It cannot be doubted that anthority of the most absolute type is the very foundation of Romanism. An exclusive Church, "without which there is no salvation," ruled by an infallible Pope: this is what we must either accept or ignore; and if it refuses to be ignored, either support or combat.

But this proud attitude of "no compromise" is becoming more and more difficult to maintain. Protestantism has adopted an expedient which, although illogical and arbitrary, may succeed in warding off the danger for a few more generations; the miraculous has been limited to the Biblical and evangelic ages; the remoteness of that period makes it easier for us to silence our critical objections; besides, the original documents are accessible to none but a few scholars, to whom we leave the care of discussing their authenticity and historicity. Roman Catholicism, on the contrary, has an unbroken miraculous tradition to defend - down to the present day. Loretto, St. Januarius, La Salette, Lourdes, St. Anthony of Padua, are integral parts of the system. One may dream of a "general confession" of the Church, of a resifting of miracles, of a frank abandonment of all those which are palpably absurd, spurious, or fraudulent. But it is a dream. Renan was compelled to recognise that no concession on the part of the Church was compatible with her supernatural claims, which in their turn were bound up with those of orthodox Christianity. Our faith is based on certain historical occurrences, related in a few documents; the selection and preservation of these documents - their veritable authorityis a matter of tradition. If we break away from the body to whose keeping this tradition was committed, we are thrown into " naturalism," individualism, free-thought. In matters of faith no authority can be accepted unless it be infallible. Supernaturalism cannot yield an inch to the enemy; if a single one of its assertions were proved to be false, a single one of its miracles to be the result of deception or illusion, a single one of its claims to be based on a forgery or a misinterpretation, the whole fabric would collapse; human reason wonld reassert its empire.

Liberal Catholicism in politics has hitherto been a failure; 


\section{FRENCH PROPHETS OF YESTERDAY}

social Catholicism, which does not imply any belief in liberty or reason, may have a future, but hardly a brilliant one; liberal Catholicism in theology is a contradiction. Under diplomatic Popes, the Modernists may enjoy a certain amount of freedom. If they are supple and persistent, they may escape excommunication, and a few individuals like Mgr. Maret or Mgr. Duchesne may even rise to high dignities. But they cannot renovate the Church. It was possible to introduce a certain amount of Rationalism into religion in the sixteenth century : faith was stronger, free-thought weaker than now. At present they had best be kept apart.

Renan prophesied, with more directness and insistence than was his wont, that Roman Catholicism was on the eve of a schism. It seemed that the moderate and liberal elements could not for ever submit to the paradoxical dictates of the Absolutists. So long as the Popes ruled a small Italian State, it was natural that the Pontiff should be an Italian : after the loss of its temporal power, the Papacy would become a field for the rival ambitions of different nations. If two Popes were elected by rival conclaves, each would "polarise" in every country one element -either the liberal or the conservative. This disruption would endanger but also strengthen historical Christianity. We need hardly say that, forty years after Renan's prophecy, there is not the least sign of its ever being fulfilled. The present Modernist movement is feeble compared with the liberal opposition before and during the Vatican Council. In the crisis of the Separation the French Catholics obeyed the Pope without a murmur, although his orders were contrary to their known desires. Never have unity and discipline been more rigidly enforced and more willingly accepted. Either Renan, with the power of vision of a historian and a poet, read into a distant future which to us is absolutely dark, or he was for once mistaken in his prophecy.

If Rome cannot alter her dogmas so as to suit the modern mind, is it possible for France, after rejecting them, to receive them anew? Will the country of Voltaire abjure Rationalism, and adopt authority again as its spiritual guide? There have been individual cases of such conversions: Augustin Thierry, a 
"weary rationalist," sought rest in the Catholic faith : "What I need at present is not broad but narrow ideas," he said. That the nation as a whole will ever follow his example is donbtful. Weary of sheer Rationalism France undonbtedly is; she is sick of logical certitudes disproved by facts, of facts that lead nowhither, of dreams that are neither comforting nor beautiful; intellectual recklessness is no longer her besetting sin. But among the many systems she has tried in the past and found wanting, Catholicism, its theology, its history, its ecclesiasticism is the one she knows best and deems most disappointing.

A Catholic reformation, a national conversion, being equally improbable, there remains another chance of conciliation. The Church still represents a great spiritual force, and especially a great moral discipline; why should not she and the modern world tacitly agree to ignore the objectionable features which cannot openly be either given up or believed in? King George V., we are told, is still supposed to be the owner of all the land in Great Britain : if such a theoretical right actually exists, who would move his little finger for its abolition? It is picturesque and harms no one. Through such a silent understanding members of the Broad Church party within the Anglican Establishment reconcile gennine loyalty to their ecclesiastical traditions with perfect freedom of thought. But this agreement is based on indifference. We camnot silently drop that which we deem vital. There is enough spiritual vitality both in French Catholicism and in its opponents to make such a truce unthinkable.

The Radical opposition of the Roman Church to modern civilisation does not mean that she is doomed, in France, to rapid extinction. She still has incomparable assets. Although a large proportion of the people have left her, the force of inertia will long keep the majority within the fold. Her conservative attitude at least gives her the clientele of the nobility and of the upper middle class, whose aim it is to imitate the old aristocracy in everything. Her pomps, her pilgrimages, her miracles, will appeal, perhaps eternally, to a large number of souls. Her antiquity, her magnitule, the artistic treasures she still 
possesses, will attract not a few men of the æsthetic-sentimental type. Her moral discipline, often accused of undue laxity, but in many cases rigid and salutary, will commend itself to those who need guidance and support. Her charitable organisation offers a splendid field for men and women who are eager to serve. Her monasteries and convents, which are not all prohibited by law, and must be more freely tolerated in the future, are an ideal haven for the poor in spirit, the unworldly, the wounded souls. Ascetic and gorgeous, sensuous and mystic, absurd and impregnably logical in its defiance of common sense, Catholicism, with its absolute claims, its miracles, and its hierarchy, will survive indefinitely.

The opposition against it is already weakening. Few indeed and negligible are the French free-thinkers or the Anglo-Saxon Protestants who still consider Popery as the embodiment of all evil. The vehement vituperations of Proudbon and Leconte de Lisle are now read with a smile. Voltairianism, in a certain sense, is not dead; it is picked up, as a convenient weapon of defence, whenever there is some danger of a theocratic revival. Anti-clericalism, which is purely political and should not be mistaken for anti-Catholicism, is not a sectarian passion but a vital, although unpleasant, necessity in any modern State.* But, while Voltairianism is still effective, it has lost caste: it is held to be shallow and vulgar. Chateaubriand, Michelet, Comte, Sainte-Beuve, Taine, and above all Renan, have taught us a new spirit. Modern French thinkers that do think have nothing but reverence for the historical grandeur of the Church, for the enormous capital of human energy and Divine aspirations which it represents. They feel that the world would be the poorer if so much power and beanty were suddenly to disappear. But all this respect and sympathy does not make them believe in what Catholicism holds to be essential. Chateaubriand's orthodoxy, based on the æsthetic sentiment, was dangerously vague and equivocal. Rome and the free-thinkers have agreed on clearing away such ambiguities. Fairness, admiration,

* Cf. the opposition to the alleged political influence of the Miormon Church-quite different from anti-Mormonism on theological or ethical grounds. 
reverence, do not necessarily imply adhesion, belief. On the contrary, a broad-minded, sympathetic, but critical listener is invincible in his scepticism, whilst an accident may turn an unjust persecutor, like St. Paul, into the most active apostle. The Church, from her own point of view, was justified in singling out Renan as her most dangerous enemy. Neither can we blame her for maintaining the integrity of her principle, and, like the Count of Chambord, preferring defeat to compromise. In spite of recent conversions confessedly due to political causes, the divorce between Catholicism and the leaders of French thought seems irremediable. This was already evident forty years ago : all the great writers were openly or tacitly estranged from the Church. Since that time a quiet revolution has taken place. The Empire, like the Republic, professed to be neutral in religion; as a matter of fact, both regimes practised tolerance rather than neutrality. But under Napoleon III. Catholicism was still implicitly the religion of the State; at present freethought is quasi-official. The general elections which followed the vote of the Separation law showed that this state of mind was not limited to the political persomel of the Republic. Catholicism has a future in France as everywhere else in the world; but it will never be again the leading factor in the religious evolution of the country. The eldest daughter of the Church is now emancipated.

\section{New Churches and New Religions.}

Would a new Church fare any better? Public opinion, as a rule, is strongly prejudiced against such attempts. In the eyes of the people they are sacrilegious, whilst the educated refuse to take them seriously. The efforts of the French Revolution in that line are still enveloped in a mist of legend. The Cult of Reason is described, even in scholarly books, as the enthronisation of a prostitute on the altar of Notre-Dame.* The ceremony in honour of the Supreme Being is associated with the hateful memory of Robespierre, who acted as officiating priest. The Theophilanthropists have escaped total oblivion,

* In spite of the attempted rehabilitation of Chaumette by E. Quinet and Aulard. 
because Laréveillère-Lépeaux, an obscure member of the Directoire, was connected with the sect. The Constitutional Church, although neither a farce nor even a complete failure, never had any real vitality. All this curious religious growth of the eighteenth century at its close was swept away by the Catholic reaction, both sentimental and political, led by Chateaubriand and Bonaparte at the time of the Consulate.

From 1830 to 1840 the spiritual unrest reached an extraordinary degree. France was big with Messianic hopes. The words of Musset, "Who among us is going to be a god?" "Tere not a mere rhetorical question; George Sand's Spiridion, which to Thackeray seemed arrant nonsense, was in tune with the exaltation of the day. Numberless Churches sprang up, most of them negligible, like the schism of Abbé Châtel, * or eren grotesque, like the synthetic religion of the Mapah. $t$ But none survived the early efferrescence of Romanticism. The Liberal-Gallican schism of Father Hyacinthe Loyson (1870) led to nothing. The man, owing to his talent, his earnestness, his true nobility of soul, escaped odium and ridicule; but the Church is now one more curious piece in the grand archæological museum of the capital. To the present day queer little sects will crop up in the great cities and thrive for a season. Gnosticism is periodically revived. Theosophy and other forms of Hinduism have a flickering existence;

* As we are concerned with the national significance of such movements, not with their intrinsic merit, we simply register the verdict-right or wrong -of public opinion. Abbé Châtel's Church, in so far as it was a continuation of the Constitutional Church, was interesting, had some success, and was shabbily treated by the Government of Louis-Philippe. Perhaps an attitude of friendly neutrality on the part of that Government would hare enabled it to linger a while longer.

† The Mapah, apostle of "Evadism," who, from his "pontifical garret," requested the Pope to abdicate in his favour, seems to have been a sincere and noble soul, coming a few centuries too late. or a few thousand miles too far West-or East. Cf. Louis Reybaud's amusing caricature of such attempts in Jerome Paturot, and a curious chapter in the Nemoirs of the elder Dumas. As for Hyacinthe Loyson mentioned infra, he is still alive, and grows broader in his religious sympathies. His work is carried on by a little Church which is a curious synthesis of all Catholic parties defeated by Rome: Jansenism, Gallicanism, the adversaries of the Concordat and those of papal infallibility. [Father Hyacinthe Loyson died while this book was in the press.] 
Babism, which has admirable parts, has a few sectaries; some twenty years ago Sâr Josephin Péladan provided mild amusement for the Boulevards with his Neo-Rosicrucian school. M. Jules Bois has devoted a whole volume to The Little Religions of Paris. As a rule, there is more conscions pose than even self-delusion and more "literature" than spirituality in these psendo-mystic quests-not to mention the eases when sensuality is one of the ingredients of the cult.

Saint-Simonism, of course, is of a different order. It remains one of the most curious phenomena of the nineteenth century. It had many elements of a true religion. First of all, it was a spontaneous growth, which developed after the death of Saint-Simon. It was not bound to any narrow formulary: it was based on the new spirit pervading the numerous writings of a versatile and erratic man of genius. This gave it an elasticity which Positivism, for instance, absolutely lacked. It came at a time of religious fermentation and political upheaval. It attracted, not an ignorant and superstitious crowd, not a frivolous set of idlers and sensationseekers, but some of the best minds of the time. Auguste Comte, Augustin Thierry, Leroux, Reynaud, H. Carnot, Michel Chevallier, Guéroult, Sainte-Beuve were, for a time at least, interested in the movement. The orthodox SaintSimonians, Olinde Rodrigues, Enfantin, Bazard, Barrault, were unusually able men. The "Father," with all his weaknesses, retained to the last an extraordinary power of fascination. They had preachers and missionaries; they were eager for martyrdom. Had Enfantin been massacred by the mob before the era of difficulties began, we might have had one prophet the more on the rolls of religious history. Their lives were transfigured : Ménilmontant became a sacred spot. Thirty years later, although Saint-Simonism had apparently failed in every respect, although it had drifted into objectionable courses, although its Pope hinself outlived his early enthusiasm, the sane, practical men-bankers, railroad promoters and directorswho had been Saint-Simonians, kept holy the memory of these few months, during which they had caught a glimpse of a new heaven and a new earth. Renan, who saw a number of them 
in their old age, was repeatedly impressed with the tender and reverent emotion which these souvenirs aroused in them. But there was no second generation: a few younger men, like Maxime Du Camp, still used Saint-Simonian phraseology in their correspondence with Enfantin; the sect died with its Father. No living trace is left of this singularly fascinating attempt.

The mystic and ritual aspects of Positivism were not developed until the late forties, although their inception can be traced in Comte's mind some twenty years earlier. When the Religion of Humanity was finally promulgated, it seemed an anachronism, the age was too matter-of-fact for that kind of Positivism. The authority of its founder, and of such men as Pierre Laffitte and Frederic Harrison, commands respect for the Church of Auguste Comte. It is certainly not absurd, nor contrary to the first principles of Comte's philosophy. Littró himself, who seceded on account of the theological tendencies of the master, said a few years before his death (1878): "The truth is that, as the Positivist regime gets stronger, something in that direction will have to be done." But such as planned by Comte in its minutest details, the new Church was the model of an artificial creation, cold, arbitrary, lifeless. Positivism, under many names, and taught by many independent masters, has been the ruling influence in European thought for the last half-century. The Positivist Church, on the contrary, grouped but a handful of men, and its influence remained insignificant.

It is not among the new Churches, therefore, that we must seek the religion of the future. The ecclesiastical system and the ritual of Catholicism are so perfect that they prevent the development of any rival organism. It the new Church is less elaborate in its services and hierarchy than the old, it seems weak and poor in comparison; if it attempts to vie with Rome in these respects, it looks like a ridiculous counterfeit of a time-honoured institution. A new religion, without Messiah, without miracles, can have neither regular clergy nor set forms of worship. If a ritual is to be evolved, it must be the growth of centuries.

France had in the nineteenth century a number of these free and purely spiritual religions. The most dogmatic, the only 
one which st sured some form of official recognition, was "Natural Religion" or Theism, the faith of Voltaire, Roussean, Franklin, Victor Cousin, Jules Simon, and likewise of Béranger and M. Homais. It had its gospels-The Confession of Faith of a Saroyard Vicar, Cousin's On the True, the Beautiful, and the Good, Simon's Duty and Natural Religion. It barely missed having its catechism, which Cousin wanted to impose on all public schools. It remains to the present day, we believe, the official basis of State education. "State Theism," "Eclecticism," "Spiritualism," as it was diversely called, should not be lightly dismissed. It had its Homais : but Catholicism had its Bournisiens and Protestantism its Chadbands. The fact that it was endorsed by "common sense" and was held to be a factor of social stability, "the religion of good citizens and fathers of families," proves little in its favour but nothing against it; true religion need not be paradoxical and revolutioniry like early Christianity. Its metaphysics is often accused of being a pale copy of orthodox theology: perhaps the reverse wonld be truer. Spiritualistic Theism goes back to Plato, Cicero, the Alexandrians, and, in its relations with the Church, gave at least as much as it received. But there is some truth in the accusation that such a "mythology of abstractions" is neither natural nor a religion. Intellectually, it lacks compelling evidence: common sense is too often another name for unreasoning prejudice. Spiritually, it has neither mystic appeal nor saving power.

Patriotism, in ancient times, was closely identified with religion. This old ideal Michelet, among others, proposed to revive. France, for the great Romantic historian, was not a mere entity but a living person. She ought to be our goddess, even as Rome was to her citizens. 'That there is a religious element in exalted patriotism cannot be denied. It prompts to heroism, to self-sacrifice; it has its ritual in the great national celebrations; its code of ethics; its legends; its saints and martyrs; its sacred literature-anthems, warsongs, poems, and orations; its symbols; its places of pilgrimage, its monuments, its temples. Michelet's Life of Joan of Avc was conceived in such a spirit: he saw in the shepherdess 


\section{FRENCH PROPHETS OF YESTIRDAY}

of Lorraine the purest incarnation of the motner-country : his book was a piece of hagiography. Such a scene as the federation in 1790 transported him. His whole History is a Bible, just as the Bible is a history, full of hymns and psalms, prophetic and apocalyptic in spirit and style. If we should object that patriotism often blunts or warps the moral sense, as in the case of Rome, eighteenth-century England, revolutionary France or Bismarckian Germany, he could reply that this holds true of all religions and is a sure criterion to know them by; fanaticism, alas! seems almost inseparable from absolute conviction. But whether patriotism in itself will satisfy our deepest spiritual needs is very doubtful. If it is the love of men like ourselves, merely because they happen to live on the same soil and to speak approximately the same language, it is not a very high ideal. It cannot reach its fullest degree of intensity, which alone gives it a heroic value, except when it has for its correlatives exclusivism, rivalry, and even hatred. It is only because the country is actually or potentially threatened that we feel called upon to die for her honour and integrity. In times of peace and concord we need some other incentive to self-sacrifice. To prefer one's own interests to those of the community in which one lives is rightly called a sin; to prefer the smaller to the larger group, as in the case of the Paris Commune, is accounted a crime. To place one's country above the commonwealth of nations cannot be a virtue. The sentiment which prompts men to say with Carlyle, "My country, right or wrong!" is not religion, but superstition. Even for Joan of Arc, France was not the supreme object of worship. She was a Christian as well as a patriot, and she offered peace to the English, so that both nations could unite in a crusade. This Michelet himself came to realise, for he transferred his allegiance from France herself to the mission of France, the Revolution.

Towards the middle of the nineteenth century the worship of the Great Revolution reached a degree of fervour which our generation can hardly comprehend. Lamartine's Girondists, Louis Blanc's and Michelet's Histories, all of which began to appear in 1847, were in their authors' intentions gospels 
rather than critical narratives. The following quarter of a century had a sobering effect on the French mind. De Tocqueville, Mortimer-Ternanx, Quinet published their studies, which were by no means blindly enthusiastic. The influence of the "Prophets of the Past," Joseph de Maistre especially, hitherto limited to a narrow school, became a factor of national importance. Then appeared the gigantic and virulent arraignment of the Revolntion by Taine, which, partial and unhistorical as it was, was effective in ruming the heroic legend. Victor Hugo's Ninety-Three is perhaps the last great work in the pure revolntionary tradition. The centenary of 1789 caused a temporary revival of the old feelings: the riots which interrupted the performances of Sardou's Thermidor in 1891 were prompted by a sort of fanaticism which was not simply political. To criticise the Revolution was a sacrilege. M. Clémencean's words, "La Révolution est un bloc," expressed the constant principle of all orthodoxies.

The principles of 1789 , the sombre epic of 1793 , formed, indeed, a sufficient basis for a religion-were it only of the Mohammedan type. France had in these souvenirs an ideal and a legend-a legend fertile in miracles. All the efforts of Carlyle and Taine have failed to disprove the fact that for a few years France was in very truth a missionary nation. Individuals may have been weak, foolish, cruel ; lower elementsvanity and greed-had undoubtedly their share in the success of the movement; it might have been better for the world, and in particular for France, if the ancient regime had been slowly, obscurely reformed. In the same way it can be maintained that the Reformation, the American Revolution, the Civil War, could and should have been avoided. Yet, right or wrong, the French Revolution had its ideal side.

Unfortunately, the revolutionary legend came to clash with two other traditions, which prevented it from becoming unquestionably national. The first was Royalism associated with Catholicism: France could not sacrifice thirteen centuries of her history to a crisis of five or six years, and the attempted reconciliation between the old and the new under Lonis-Philippe satisfied neither extreme. The second was Bonapartism, which 
gradually absorbed all the military glamour of those wonderful twenty years. Until 1848 Bonapartism and the Revolution worked harmoniously together : the election of Louis-Napoleon by the Conservatives, and the Coup d'Etat of 1851, separated the two legends and weakened them both. Grambetta, in 1870, failed to renew the miracles of 1792, and the French finally lost faith in the supernatural virtue of their Revolution.

It was reserved for the Third Republic, through no fault of its own, but by the mere fact of its peaceable, useful, humdrum existence, to destroy what little prestige the legend still possessed. The Immortal Principles of 1789 are taught in every school; the bust of Marianne has replaced everywhere that of Tiberius Badinguet; the fatidic words Liberty, Equality, Fraternity adorn the pediment of all public buildings; the Tsar of Russia listens, bareheaded, to the strains of the "Marseillaise"; * and yet the Millennium is not perceptibly nearer. The revolution belongs entirely to the past; its work is done--some of it has to be undone; it has no message for our souls.

But the revolutionary spirit survives. Already in the forties men began to realise the discrepancy between the principles, the aspirations of 1789 and the actual results of the movement. This effort towards universal justice had led to conquests, with their inevitable consequence-military despotism ; the Rights of Man had been bartered for the soldier's servitude and barbaric glory; a new privileged order, the capitalists, had replaced, without any great advantage, the abolished aristocracy. Thus a new Revolution came to be dreamed of, a Revolution of which the first was but a prelude. Humanitarianism superseded patriotism as an ideal, and Socialism political democracy. There, again, we had a religion rather than a party. The rigid pseudo-science of the Marxians, the violence and selfishness of certain labour unions, should not blind us to the spiritual grandeur of Socialism at its best. As represented by Proudhon or George Sand, it stood for justice and love. It had much in common with early Christianity: it appealed to the generous side of human nature; it preached service and sacrifice, instead

" "Tremblez, tyrans, et vous, perfides" ("La Marseillaise"). 
of strife and greed. It was apocalyptic and Utopian, historians tell us with a sneer; therein lay the secret of its religious power. It promised a day of judgment in this generation, and a new Jerusalem.

Socialism is only one of the aspects of Humanitarianism, and insurrection one of the accidental phases of Socialism, but the Conservatives affected to make no difference between the three. In the mind of M. Thiers "Romanticism and the Commune were one." The violent outbreaks of June, 1848, and 1871, followed by crushing defeats, ruined humanitarian Socialism for two generations. But so ferocious was the repression ordered by Cavaignac and Thiers that it assumed the character of a persecution rather than of measures of self-defence. Thus it strengthened Socialism for future revenge by giving it the consecration of martyrdom.

Thus, in spite of errors and crimes, not inherent in its doctrine, but committed in its name and too severely expiated, Humanitarianism survives to the present day, as a faith, a hope, a discipline. It was an essential part of the religion of the great Romanticists, Hugo, Lamartine, George Sand ; it remains the spiritual backbone of France. A dozen years ago, when a great moral issue was placed before the country, when the Catholics seemed to think only of material order, conservation, and safety, it was in the name of Humanitarianism that Zola led his great crusade for truth and justice. It was our privilege to attend many a tumultuous meeting in those days; with quiet courage the speakers-scholars, scientists, ministers, anarchists, for all were welcome to their share of honour and danger-were facing obloquy, ostracism, and even death; no elaborate High Mass in an ancient cathedral, no revivalist meeting of the most successful evangelist, has ever given us a deeper feeling of what religion should be.*

* We could emphatically endorse the following lines: "C'est par l'Affaire [Dreyfus] que les hommes de notre génération ont communié pour la première fois dans l'Humanité. Pour nous, elle a été, et elle demeure, une religion. Toute notre vie, nous porterons au front glorieusement ce baptême d'outrages et de larmes. A ce signe, nous nous reconnaitrons"-Paul Hyacinthe Loyson, Les Droits de l'Homme, weekly, November 13,

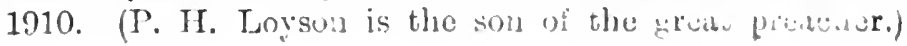


So evident was the religious character of Humanitarianism at that time, that a curions attempt was made to give it a ritual. A former priest, Victor Charbonnel, organised several serrices, which, owing to his ecclesiastical experience and to the enthusiasm of the public, were undoubtedly successful. Songs, readings, recitations, addresses, composed the programme. Hugo, Michelet, Zola, Anatole France, were the Fathers of the new Church. We remember a "Human Christmas," a "Festival of Reason." The hero of the latter occasion was Marcellin Berthelot-surely a better personification of the goddess than Citizeness Momoro! The speech of the veteran scientist was listened to with a degree of reverent eagerness not always gliznted to sermons.

But as moral order was restored this fine enthusiasm fell. Humanitarianism is a spiritual reserve in case of national emergency; it is not a faith for the daily needs of the individnal. As a religion, its weaknesses are many. It is based on a series of optimistic assumptions-the innate goodness of man, the veracity of human reason, the reality and constancy of progress, the possibility of immediate and radical improvements-assumptions which, alas! are difficult to maintain in the teeth of experience. Then it cannot abandon its ideal, its myth as Sorel would say, of a revolution ever at hand, through which the old order will give place to the new; if it did give up that apocalyptic hope, it would lose its romantic and spiritual appeal, and sink to the level of a mere philosophy and of a party. The early Shristians too expected a great revolution and the destruction of the ancient world. But they were passive; they had but to. watch and pray, and wait for the second coming. The modern Millenarian feels bound to hasten the consummation he hopes for. In this he is comparable, not with the Christians but with the Jews of the first and second centuries-haunted with Messianic dreams, rushing into mad rebellions, which invariably ended in defeat and massacre. Even with the noblest intentions apocalyptic Socialism is a danger, and if Socialism is not apocalyptic it ceases to be a religion.

The worst weakness is on the doctrinal side. The movement, strong both materially and sentimentally, has not yet been able 
to constitute its theology. It wavers between agnosticism, theism, antitheism, atheism, and pantheism. One of its theories could serve as a fundamental dogma: Mankind, in its totality, is the Incarnation, the superior Being of whom we all are members, in whom we live and move and have our being. This, propounded by Comte, eould easily be reconciled with a scientific view of the world, with Hegelianism, and with the extreme developments of liberal Christianity.* But this dogma lacks authority-not only the supernatural authority of Divine revelation but the human authority of evidence and common acceptance. To the scientist it is nothing but an attractive and poetic hypothesis, without any bearing on the facts of nature, and receiving no support from them. To the popular mind it is meaningless.

Potent still is the appeal of Humanitarianism, in that it seems to imply faith, hope, and charity; yet, weak except in times of crisis, dangerous because it fosters dreams of upheaval and conflagration, unsatisfactory for the intellect, it cannot be the sole religion of the future: but it will more and more be recognised as one of its essential elements.

The latest idol, in the words of de Curel, is Science. Strada, the crack-brained epic poet, turned his residence into a Temple of the Religion of Science. Many a saner or more commonplace man did the same in his heart. Indeed, when Brunetière dared to proclaim that, as a religion, science was bankrupt, loud was the outery against the "obscurantist."

Who loves not Knowledge? Who shall rail against her beauty? But science is still the privilege of a few, and it only helps these few to fathom their ignorance. In SainteBeuve's words, it is " a flickering toreh in the midst of boundless night." Even within that narrow eircle of trembling light it has no moral authority, no spiritual significance. A life ruled according to seience alone, if that were possible, would be a life of enlightened selfishness. A man may know intellectnally which is the right course, and find in that knowledge no assistance against temptation. Learned physicians have fallen victims to the drink habit, and investigations in arteriosclerosis did not cure them. Whenever the interest of the individual clashes

* Rev. R. J. Campluell's New Theulogy. 


\section{8

with that of the race, by what authority will science demand self-sacrifice? Useless for the ignorant, the weak, the selfish, the religion of science has nobler opponents - the sentimentalists, the idealists, the mystics, who will not accept the laws of physical nature as their spiritual rule. "But these laws, if you disregard them, will infallibly crush you!" What matters it? They may destroy, they cannot save. Pascal and Vigny have taught us that a single soul is more than the material universe. The theology of the new religion will have to take science into account: an astronomy, a geology, a history contrary to ascertained facts can no longer be defended on the plea that they are sacred. In the same way the new ritual cannot afford to ignore hygiene and sociology. Medicine will enlarge its field at the expense of thaumaturgy. Many moral precepts will perhaps receive a scientific formula. Science will thus become a useful ally for religion, rather than a substitnte; for "she is the second, not the first; she cannot fight the fear of death; for she is earthly of the mind, but Wisdom heavenly of the soul."

\section{Supernaturalism and Naturalism.}

Such were the terms of the problem which France had to face at the fall of the Empire; supernatural religion, in spite of the material power of the Church, was steadily losing ground; no form of natural religion could aspire to spiritual hegemony. After forty years the conditions are substantially the same: the old is weaker, the new not stronger; no authority has risen from the ruins.

When we deal with supernatural religion from its own point of view we cannot affirm anything about the future. The future is not in human hands; we must reserve the possibility of a miracle. Either historical Christianity may revive in France, or a new revelation be the foundation of a new faith. But nothing short of a miracle can effect it.

If the evolution of French thought continues unchecked, the place held hitherto by orthodox religion will be filled by humanitarian Socialism, both sentimental and practical: by science in the intellectual field, by Agnosticism in the metaphysical. Perhaps we shall have the "ethics without obligation or 
sanction" outlined by Guyan. In such a case the future of religion would amount to the "irreligion of the future,"*

If this came to pass, would a great gloom fall over the world? Would the horror and despair which filled Scherer and Mme. Ackermann become a universal experience? Perhaps not. The nobler souls alone, at any rate, would suffer: most men live comfortably without metaphysical beliefs at present. The struggle in which Renan and Scherer lost their faith in the absolute was exceedingly painful : yet both survived the ordeal, and lived usefully and happily for many years. Perhaps one generation has suffered for all : the second "mal du siècle," the melancholy which heralded the coming of relativism, may have been a crisis in the growth of the race which will not occur again.

Religion is immortal within the individual soul. What falls under our notice is not its spiritual essence, but its intellectual, social, moral effects. We could afford to let theologies and Churches pass away, if the love of goodness and truth were to remain intact.

The supreme question, therefore, is this: Is the religion of the ideal bound up with any particular tradition, any metaphysical system, any ecclesiastical form? In other words, has mankind the means of salvation everywhere and at all times within itself, or is it doomed to perdition unless, abdicating its spiritual autonomy, it receives miraculous aid from above? So we are finally confronted with the irreducible antinomy : naturalism and supernaturalism.

"The progress of this world may be irregular and slow," says the naturalist, "but it is certain. Our age of tolerance and scepticism is not morally degenerate. Science, free-thought, humanity, have their saints, their heroes, their martyrs. Any Church would be proud of men like Michelet, Quinet, Taine, Renan, Littre. A spirit of gentleness, of fraternity and iustice, is growing fast, and faster among the unbelievers than among the orthodox. Priests denounce the peace movement, whose most ardent advocates are agnostics.t The apostle of universal con-

- M. J. Guyau, Essai d'une Morale sans obligation ni sanction-L'Irréligion de l'Avenir. 
cord through a world-language, Christ-like in his disinterested devotion to the ideal, is an emancipated Jew. Our democracy of infidels is governed by men who, with all their frailties, are better than Abraham, Jehovah's friend. Our colonial wars are models of scrupulous humanity compared with the heaven-led conquest of the Promised Land. Our worst act of intolerance, the expulsion of a few nuns, is a venial sin compared with the Inquisition. Our efforts for righting social wrongs are as beautiful as and more enlightened than all the foundations of monastic charity. Our search for truth, in unknown continents, in libraries and laboratories, is more modest, more patient, more heroic, more fruitful, than the baseless elucubrations of all the theologians. We no longer believe in the absolute goodness of human nature, in the possibility of its sudder regeneration : man is late risen from animality. But, urged by a universal instinct, with reason as his sole guide, he slowly better's the world and himself."

"It is true," replies the supernaturalist, "that the fruits of unbelief are not immediately seen : I will not bring up against you symptoms in your country which seem ominous enough even to sympathetic observers. The leading nations of the world are predominantly Christian, and you dare not fall too far behind them; although less assertive than their rivals, the Catholies are still a majority in France; besides, the good habits of eighteen centuries are not lost in one or two generations. But the virtue of the natural man, without heavenly assistance, is singularly precarious. Without faith, stoic despair or refined Epicureanism are your only alternatives: Taine chose the first, Renan the second. All your boasted love for justice and reason, which you take to be the dawn of a better day, is but the afterglow of your setting faith. Listen to the words of your greatest apostle: 'At first sight, humanity in our days is driven to a position whence there is no escape. The old beliefs through which man was helped in practising virtue are shaken, and have not been replaced. For ourselves, cultivated minds, the equivalent for these beliefs offered by idealism, are quite sufficient; for we act under the empire of ancient customs; we are like those animals whose brains have been removed by physiologists, and 
which continue none the less to perform certain vital functions, as the effect of habit. But these instinctive movements will grow weaker and weaker with time. To do good in order that God, if He exists, may be pleased with us, will seem to many an empty formula. The faith we live by is but the shadow of a shadow; what shall they live by that come after us?' "*

Shall we thus close this review on a discord? Irreducible indeed seem the two voices which alternate, eternally, in every nation, perhaps in every heart. Yet what are they but effortshuman efforts, and therefore hopelessly inadequate-to express the same aspirations? Supernaturalism is the poetry, naturalism the prose of spiritual life: shall we condem all poets as nonsensical sentimentalists, all prose writers as commonplace drivellers? Are not all needed in the miversal choir? Under many names, in unlikely places, we have found "morality-and metaphysies-tonched with emotion." Whether in the mutterable eestasy of the mystic, in the blindly accepted orthodoxy of the traditionalist, in the pomps of the ritualist, in the social derotion of the humanitarian, in the patient and lonely labour of the scientist, wherever there is passionate longing for infinite goodness and truth, wherever there are lives transformed and upheld by the thought of eternal things, sectarian names and formal creeds matter little: there is religion :-

"Our little systems have their day;

They have their day, and cease to be :

They are but broken lights of Thee, And Thou, O Lord, art more than they."

* Renan, Dialogues Philosophiques, Preface, xix. It is true that Renan goes on to say: "Mankind will ever be able to evolve the amount of illusion necessary to its spiritual needs." But is not this a bare affirmation? And if our hopes are indeed naught but an illusion, will there not be an ever-inereasing number of men to sce through it? "What shall they live by that come after us?" 


\title{
BIBLIOGRAPHICAL NOTE
}

\author{
Main SOURCES.
}

Political History.

There is no handy and scientific history of the period in French or in English.

Taxile Delord : Histoire du Second Empire (Baillière [Alcan], 1868-75, 6 vols., $8 \mathrm{vo}$ ) is journalistic in thought and style, but valuable as a contemporary document. The same is true of Larousse's Grand Dictionnaire Universel. The difference between the volumes published before and after 1870 is striking, and not seldom amusing. (Cf. Bonaparte and Napoleon.)

P. DE LA GORCE: Histoire de la Seconde République (Plon, 2 vols., 8vo, 1887) and Histoire du Second Empire (Plon, 7 vols., 8vo, 1894-1905). Somewhat diffuse, strong conservative bias, but full, conscientious, and readable.

Emile Ollivier: L'Empire Liberal (Garnier, 1894). Most of the chapters appeared in the Revue des Deux Mondes. A personal apology, unreliable, but of commanding interest.

A. Thomas : Histoire Socialiste: Le Second Empire (Rouff). Although it is part of a popular and partisan series, this is an excellent piece of work.

T. Delord and A. Thomas are illustrated. For pictorial documentation in convenient form, A. Dayot, L'Histoire de France par l'Image, Le Second Empire.

\section{Literary History.}

Cf. H. P. Thieme: Guide bibliographique de la littérature française de $1800 \dot{\alpha}$ 1906 (Paris, Welter, 1907, 8vo). Indispensable.

Among the few omissions of special importance to our subject : $X$. Doudan, A. Lefèvre, Strada (Delarue), Octave Feuillet's Sibylle, 1862.

\section{Religious History.}

A. DeBIDOuR: Histoire des rapports de l'Eglise et de l'état en France de 1789 à 1870 (Alcan, 1898, 8vo). Convenient collection of facts, useful bibliographies, marred by polemical tone. 
Salomon Reinach : Orpheus (Picard, Paris; Heinemann, London; Putnam,

New York, 1909). Lucid summary. Bibliographies-Voltairian in tone. G. WEILL: Le Catholicisme Francia an XIXème siecle, extrait de la Revue de

Synthese historique, December, 1907. Excellent general indications.

The author wishes to thank Professors Gustave Lanson and Charles Seignobos, of the Sorbonne, Paris, for helpful suggestions offered in private conversations during the summer of 1910 . 


\section{INDEX OF PERSONAL NAMES}

Small capitals indicate the authors whose works were published or written between 1848 and 1870, and had a bearing on religious thought. The pages where they are more particularly studied are indicated by heavier figures.

Aвout, Edmond, 107, 108

AckermanN, Mme. Louise, 22, 90, $161,181,191,195,258-9,279$

Ackermann, Paul, 174

Aschylus, 64

Aguettant, 67

Alembert (d'), 216

Allier, 247

AMieL, Henri-Frédéric, 22, 212, 247

Antonelli, Cardinal, 55

Aristotle, 61

Arnold, Matthew, 143

Aubigné, Merle d', 26, 85

Augier, Emile, 25, 44, 69, 107, 160, 256

Augustine, Saint, 61, 63, 184

Aulard, A., 267

Babbitt, Irving, 255

Bacon, Francis, 60, 165

Ballanche, Pierre, 124

Balzac, H. de, 36

Banville, Theodore de, 180, 192

Barbès, 129

Barbey d'Aurevilly, J., 12, 25, 27, $28,34,36-45,45,53,63,104$

Barrault, 130, 167, 269

Barrès, M., 255

Baudelaire, Ch., 12, 34, 35, 36-43, 44, 174, 180, 197, 200

Baunard, Mgr., 26

Bautain, Abbé, 59, 229

Bayle, P., 216

Bazard, 269

Beranger, 25, 109, 201, 242, 270

Bernard, Claude, 165, 214, 256

Berryer, 25

Berthelot, M., 147, 165, 213, 214, $231,241,250,254,256,276$

Beyle, H., 109, 110
Biré, E., 141, 150, 213

Blane, Louis, 95, 129, 145, 272

Blanc-Saint-Bonnet, 26

Blanqui, 31, 129

Bloy, Leon, 28, 43, 63, 68

Bois, Jules, 269

Bonald, de, 167

Bonjean, 29

Bossuet, 29, 44, 45, 48, 61, 70, 83, 93, 184, 258

Bouilhet, L., 181

Bourget, P., 13, 255

Brizeux, 34

Broglie, A. de, 51, 54, 69

Brunetière, F., 25, 26, 60, 229, 277

Buisson, F., 74

Buloz, F., 239

Bungener, F., 72

Burckhardt, 259

Burke, 52

Byron, 35, 36, 108, 174, 187

Cabet, 129

Calvin, 10, 75, 79, 135, 138, 160

Campbell, R. J., 177, 277

Carlyle, 213, 239, 273

Carnot, 269

Caro, E., 22, 106, 213

Cavaignac, 129, 275

Cavour, 51

Challenel-Lacour, 161

Chamning, 97

Charbonnel, Victor, 276

Charlemagne, 123

Charles X., 125, 203, 261.

Chateaubriand, 29, 34-8, 41-4, 109, $122,149,164,189,209,214,218$, $225,233,256,266,268$

Châtel, Abbé, 268

Chaumette, 267 


\section{INDEX OF PERSONAL NAMES}

Chevallier, Michel, 168, 269

Childe, Mrs., 114

Cicero, 271

Clémenceau, G., 9, 273

Clovis, 16,32

Cochin, A., 29, 51

Coignet, 71

Colani, 72, 76-7

Colenso, 87

Coligny, 10, 260

Combes, 10

Conte, Auguste, 16-18, 21-2, 88, 104, 146, 166-71, 175, 1S1, 212-13, $225,251,266,269,270$

Condillac, 215-16

Considérant, 129

Constantine, 16

Cook, 71

Coquerel, Athanase, Jr., 72, 77, 82-3

Cornoille, 220

Coulanges, 93, 106, 127

Cousin, Victor, 20, 60, 146, 163, 201, 216,271

Creuzer, 98, 165

Curel, 277

Danton, 147

DARWIN, Ch. (translated by C. Royer), 12, 16-17, 104, 146, 165, $181,186,214$

Descartes, 162, 165, 184, 189, 220, $232,251,256$

Diderot, 107, 216, 219

Didon, Father, 238

Döllinger, 62

Doudan, X., 44, 104, 106, 109

Doumic, 25-6

Douniol, 63

Dreyfus Case, 189, 255, 275

Du Camp, Maxime, 270

Duchesne, Mgr., 264

Dumas, A. (the father), 37, 193

Dumas, A. (the son), 160, 199, 256

Dumas, Georges, 171

Dupanloup, Mgr., 22, 28, 33, 47, 51-7, 59, 120, 163, 172, 201, 204, $213,227,228,257$

Dupuis, 165, 216

Durur, V., 201

Duvergier de Hauranne, 104

Eliot, G., 235, 259

Emerson, 97

Enfantin, Father P., 167-8, 269, 270

Epicurus, 208
Esquirol, 220

Eugénie, the Empress, 17, 110, 241

Faguet, E., 25-6, 106

Falloux, de, 28, 51-2, 54-5

Felix, Father, 27

Fénclon, 48, 61, 184

Ferry, J., 9

Feurbach, 243, 253

Fivre, Mgr., 59

Flaubert, G., 39, 103, 108, 160, 164, 252,256

Foisset, 'Th., 51

Fourrier, 125

France, A., 171, 174, 255, 276

Francis, St., 136

Franklin, B., 271

Fréret, 216

Gambetta, L., 9, 274

Garibaldi, 114

Garnier-Pagès, 145

Gasparin, A. de, 72, 76

Gaussen, 81

Gautier, Th., 36, 37, 180, 191-2, 233

Génin, 127

Gerson, 70

Gibbon, 79

Gobineau, de, 230

Goethe, 15, 40, 174, 218-19, 221

Goncourt, E. and J., 160, 250

Goroni, Father, 26

Gottofrey, Abbé, 229

Grant Duff, Sir Mount Stuart, 235

Gratry, Father, 19, 22, 25, 28, 51, 56-60, 62-5-8-9, 150, 163, 182, $236,257,262$

Gréard, 86, 90

Gregory IV., 54

Gregory VII., 54

Gregory XVI., 50, 53

Guéroult, 168, 269

Guizot, F., 30, 72, 77, 78-83, 84, 92, $161,171,210,257,259$

Guyau, MI. J., 279

Harrison, F., 270

Hartmann, 161

Haussonville, O. d', 207

HAVET, E., 61, 217, 219, 236

Hegel, 90, 163, 176, 216, 219

Heine, 127

Heila, E., 22, 25, 28, 63-8, 69, 163, 225,236

Henri IV., 260

Herder, 131, 164

Hoffmann, 36

Holbach, 215 
Homais, 103, 271

Homer, 42, 64, 114

Hugo, V., 17, 19, 20, 25, 34, 44, 48, $62,65,67,69,93-4,114-5-8-9$, $124-9,131-5-8,141-58,160,175$, $180-2-6,192-3,207,212-19,247$, $256,257,273-5-6$

Hume, 209

Huxley, 12

Huysmans, 12, 27, 43, 67-9

James, William, 221, 229

J ANET, P., 22, 81

Jouffroy, 85, 90, 213

Julian (Emperor), 259

Julleville, 26

Kant, 1., 20, 243

Kardec, Allan, 107

Laboulaye, E., 72

Labruyère, 48

Lachâtre, M., 107

LACORDAIRE, H., 19, 25-6-7-8, 30, $41,50-1-3-6,62,67-9,201-4,262$

Laffitte, P., 270

Lafontaine, 178, 208

La Hire, 230

Lahor, J. (Dr. Cazalis), 181, 191

LAMARTINe, A. de, 19, 20, 21, 34, 51, $69,93,118,126,129,130,145,151$, $171,180,186,227,272,275$

Lamennais, F. de, $32,50,62,64,67$, $93,124,126,127,129,130,145$, $167,180,201,225,229,231,254$, 262

Lamettrie, 215

Lanfrey, 107

Lanson, 25

Laplace, 162

IJAPRADE, V. de, 25, 34, 204

La Réveillère-Lepeaux, 268

Larochejacquelein, Mme. de, 111

Larousse, 107

Lasserre, 119

Latreille, 32

LeCONTE DE LisLe, 22, 26, 34, 69, $90,163,164,174,175,181,191-200$, $220,232,256,258,266$

Ledru-Rollin, 145, 146

Lefebvre d'Etaples, 70

Lefèvre, A., 181

Leibnitz, 60, 61

Lemaitre, J., 25, 26, 27, 90, 91, 199, 255

Iseo XIII., 33, 57, 262

Leopardi, 194
Leroux, P., 62, 125, 128-30, 167, 180, 269

Leverrier, 165

Levy-Bruhl, 171

Libri, 127

LITTRÉ, E., 12, 15, 16, 22, 61, 81, 146, 147, 165, 166-72, 200, 201, 204, $213,214,216,251,256,270,279$

Loader, Rev. Th., 84

Loisy, 262

Lombroso, C., 64

Longhaye, Father, 26, 46

Louis IX.-Saint Louis, 32, 123

Louis XIV., 71, 135

Louis XVI., 71, 79

Louis XVIII., 123

Louis-Philippe, 32, 78, 106, 111, 124 , $126,128,182,203,268$

Isoyola, 16

Loyson, Father Hyacinthe, 27, 31, $36,39,62,68,262,268,275$

Loyson, Paul-Hyacinthe, 275

Lucretius, 174, 208

Luther, 58, 70, 75, 135, 138

Lyell, 166

Maeterlinck, 43, 68

Maine de Biran, 213

Maistre, Joseph de, 26, 29, 32, 33, 42, $43,45,50,53,58,124,127,167$, $201,227,273$

Malebranche, 61, 228, 229, 232, 251, 253,256

Mame, 63

Mapah, 268

Marcus Aurelius, 16, 90, 99, 222

MARET, Mgr., 56, 56-9, 68, 264

Marx, Karl, 172, 173

Mathieu, Mgr., 175, 179

Maunoir, Camilla, 183

Maury, Alfred, 201

Mazzini, 31, 120

Menard, Louis, 181

MÍRIMÉE, P., 37, 69, 97, 104, 109-117, 141, 175, 202, 235, 236, 239,246

Metternich, 30

Michelet, 12, 19, 20, 21, 25, 34, 36, $62,69,93,95,98,118,127,129-$ $41,145,151,160,212,216,218$, $227,228,238,239,252,256,266$, $271,272,276,279$

Mill, J. S., 171, 216, 219, 251

Milton, 35

Molière, 48, 208, 216

Mommsen, 237, 239

Momoro, Mme., 276

Monod, Frederic, 72, 76 


\section{INDEX OF PERSONAL NAMES}

Monod, Gabriel, 72, 141

Montaigne, 115, 163, 206, 208, 209, $210,225,246,256,262$

Montalembert, 22, 25, 28, 30, 31, $33,34,44,51-6,68,69,87$

Montesquieu, 135

Morley, 12,101

Morny, de, 169

Mortimer-Ternaux, 95, 118, 273

Musset, 158, 180, 183, 268

Nanteuil, Celestin, 118

Napoleon I., 109, 122, 141

Napoleon III.-Louis Napoleon, 16, $31,44,49,52,56,58,111,120$, $129,130,148,168,181,203,204$, $242,257,261,267,268,274$

Napoleon, Prince, 107, 108, 111

Newman, 58

Newton, 162

Niebubr, 239

Nisard, 119

Olier, 228

Ollivier, Emile, 17, 53

Ozanam, 29

Panizzi, 110

Parigot, H., 226

Pascal, 29, 45, 60, 61, 68, 185, 187, $189,206,209,278$

Passy, Frederic, 72

Pasteur, 166, 171, 214, 219, 256

Paul, Saint, 208, 242

Paulsen, Friedrich, 240

Paulus, 239

Péladan, Sâr Joséphin, 269

Pelletan, E., 73, 131

Persigny, de, 215

Petau, 61

Peyrat, 95

Pie, MIgr., 58

Pierreclos, Mme. de, 171

Pius IX., 17, 30, 31, 32, 33, 47, 53, $56,68,256,262$

Pius X., 262

Plato, 61, 64, 271

Pompadour, Mme. de, 102

Ponsard, F., 118

Pontmartin, A. de, 103

Porée, 102

Poussielgue, 63

Proudhon, P.-J., 31, 49, 90, 129, $133,150,172-9,215,236,254,257$, 266,274

Quatremère de Quincy, 239

Quinet, E., 12, 20, $18,69,72,92-$ $100,118,127,129,130,131,135$,
$138,145,160,164,165,252,256$, $267,273,279$

Rabelais, 138, 207, 216, 219

Rachel, 118

Racine, 220

Ranke, 239

Raspail, 114, 145

Ravignan, 27

Reboul, 34

Remusat, A. de, 119

RENAN, E., 12, 17, 19, 22, 34, 58, 59, $61,64,67,69,72,77,84,86,90$, $91,93,99,104,107,108,147,150$, $162,163,164,165,171,172,174$, $201,204,212,222,225-55,259,264$, $266,269,279,280$

Renan, Henriette, 226, 228, 230, 234, 243

Renan, Mme., 242

Renouvier, C., 212

Reuss, $72,76,84$

Réville, 72

Reybaud, L., 268

REYNAUD, J., 61, 125, 129, 154, 214, 251

Richelieu, 71

Richepin, 197

Robespierre, 95, 207

Robin, 108

Rodriguez, Olinde, 269

Rollinat, M., 43

Rosalie, Sister, 29

Rossi, 30

Rostand, 72

Rothschild, 237

Rousseau, J.-J., 20, 21, 79, 96, 107, $120,121,135,220,270$

Roussel, Rev. Napoleon, 113

Royer, Clémence, 166

Royer-Collard, 213

Ruysbroek, 66

Sabatier, 72

Sacy, Silvestre de, 233

SAINTE-BEuVE, $15,22,27,37,39,40$, $41,44,53,69,107,108,111,114$, $160,163,164,165,168,171,201-$ $12,215,223,226,236,239,247$, $252,256,257,259,266,269,277$

Saint-Martin, 90

Saint-Simon, Duc de, 26

Saint-Simon, Henri, 44, 125, 129, 166 72, 269

SAND, George, 62, 69, 97, 107, 118, $120,127,128,129,130,131,138$, $145,151,160,168,169,236,241$, $256,268,274-5$

Sand, Maurice, 97 
Sandeau, J., 182

Sangnier, M., 262

Sardou, V., 273

Scherer, 44, 47, 72, 76, 77, 83-92, $100,150,163,164,172,201,213$, $236,256,257,259,279$

Schneider, 169

Schopenhauer, 161, 175, 194

Scott, Walter, 192

Séailles, G., 226

Séché, I. , 183

Secretan, 72

Shakespeare, 65, 197, 220

Shelley, 174

Srmon, Jules, 26, 100, 271

Socrates, 60

Soumet, A., 34

Spencer, H., 12, 16, 81, 104, 251

Spinoza, 184, 215, 216, 219

Stapfer, P., 72

Strada, 67, 212, 277

Strauss, 175, 235, 238

Sue, E., 25, 97, 98, 107

Sully-Prudhomme, 22, 191

Swetchine, Mme., 53, 201, 204

Swift, J., 102, 230

Swinburne, A. C., 43

Tacitus, 67

TAINe, H., 12, 17, 22, 29, 38, 69, 95, $97,108,146,147,162,163,164$, $171,201,212-23,244,245,250,255$, $258,259,273,279$

Teba y Montijo, Countess of, 110

Tennyson, A., 148 (quoted), 281

Ternaux, Mortimer--, 95, 118, 273

Thackeray, W. M., 268

Thierry, A., 164, 233, 264, 269

Thiers, A., 77, 95, 101, 104, 111, 119, 201,275
Thomas, Saint, 61, 63, 65

Thomassin, 61

Tocqueville, A. de, 273

Tournemine, Father, 102

VACHEROT, P., 59, 61, 163, 212, 219

Vaton, 63

Vaux, Clotilde de, 170

Verlaine, P., 12, 40, 13

Veuillot, Eugène, 19, 22, 45

Veuillot, Louis, 17, 26, 31, 33, 34, $44-9,51,52,53,54,55,56,61$, $63,67,93,103,104,107,133$, $141,173,203,230,238$

Vianney, J.-B., 29

Vico, 131

VImennet, J.-P., 105, 107

VignY, A. de, 19, 22, 26, 34, 35, 39, $41,64,68,90,118,121,123,124$, $126,129,131,160,175,180,181-91$, $193,194,195,200,222,235,253$, $256,258,259,278$

Villemain, 1C4, 110

Villiers de l'Isle-Adam, 28, 43, 67

Vinet, 207

Vitet, 172

Viviani, 10

Volney, 215, 216

Voltaire, 16, 20, 21, 45, 60, 77, 101-8, $115,116,121,135,150,158,162$, $163,208,259,264,270$

Waldeck-Rousseau, 9

Walpole, 78

Wesley, 71

Wilde, O., 43

Ziska, 16

Zola, E., 241 





\section{HOM監USE

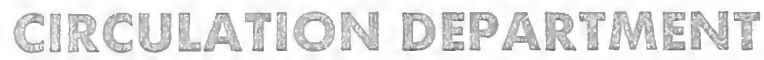 \\ MAIN DIBRAR}

This book is due on the last date stampet below.

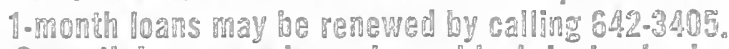
6.month loams may be recharged by bringing books to Circulation Desk.

Renewals and recharges may be made 4 days poivr to due date.

ALR BOORS ARE SUBECT TO REOALL T IAYS MPTER DRE CHECRED OUT.

\section{APR 2 51976}

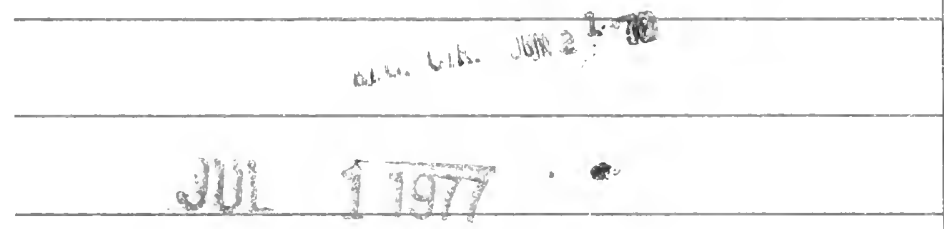

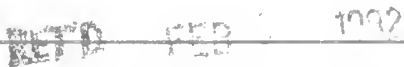

ID $21-A-40 m-5,74$

(R8191T)
General Library

unisersity of califomia

Berkeley 
U. C. BERKELEY LIBRARIES

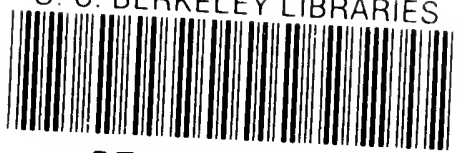
c047440772 
